February 2005 - NREL/TP-550-34607

\title{
Evaluation of the Low-Energy Design and Energy Performance of the Zion National Park Visitors Center
}

P. Torcellini, N. Long, S. Pless, and R. Judkoff

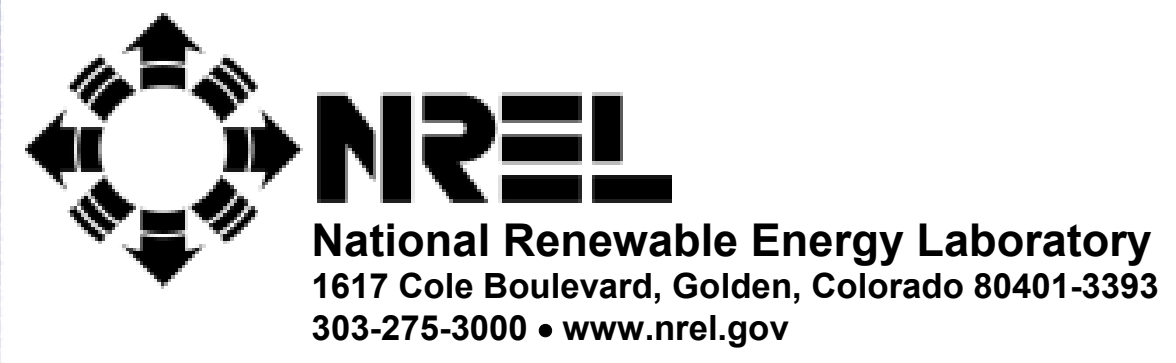

Operated for the U.S. Department of Energy Office of Energy Efficiency and Renewable Energy by Midwest Research Institute $\bullet$ Battelle 







\section{NOTICE}

This report was prepared as an account of work sponsored by an agency of the United States government. Neither the United States government nor any agency thereof, nor any of their employees, makes any warranty, express or implied, or assumes any legal liability or responsibility for the accuracy, completeness, or usefulness of any information, apparatus, product, or process disclosed, or represents that its use would not infringe privately owned rights. Reference herein to any specific commercial product, process, or service by trade name, trademark, manufacturer, or otherwise does not necessarily constitute or imply its endorsement, recommendation, or favoring by the United States government or any agency thereof. The views and opinions of authors expressed herein do not necessarily state or reflect those of the United States government or any agency thereof.

Available electronically at http://www.osti.gov/bridge

Available for a processing fee to U.S. Department of Energy and its contractors, in paper, from:

U.S. Department of Energy

Office of Scientific and Technical Information

P.O. Box 62

Oak Ridge, TN 37831-0062

phone: 865.576 .8401

fax: 865.576 .5728

email: mailto:reports@adonis.osti.gov

Available for sale to the public, in paper, from:

U.S. Department of Commerce

National Technical Information Service

5285 Port Royal Road

Springfield, VA 22161

phone: 800.553 .6847

fax: 703.605.6900

email: orders@ntis.fedworld.gov

online ordering: http://www.ntis.gov/ordering.htm 


\section{Acknowledgments}

This work was made possible under the U.S. Department of Energy's (DOE's) Office of Energy Efficiency and Renewable Energy. We appreciate the support and guidance of Dru Crawley, DOE Program Manager for High-Performance Buildings as well as the following people who reviewed this document prior to publication: John Ryan at DOE; Michael McCabe at Navigant Consulting; Nadav Malin at BuildingGreen, Inc.; and Patrick Shea at the National Park Service. In addition, we would like to recognize those who helped collect information and provide analysis support for the effort including Stefan Craine, Kris Lasnik, and Michael Ketcham (NREL interns); Peter Ellis, Brent Griffith, Sheila Hayter, and Lauren Poole (NREL); Tom Wood (Montana State University); Joshua Bruce (former NREL employee), and Ed Hancock (Mountain Energy Partnership). 


\section{Table of Contents}

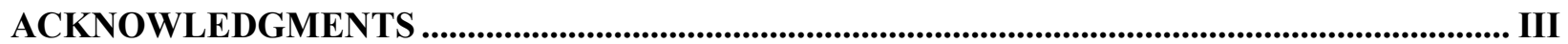

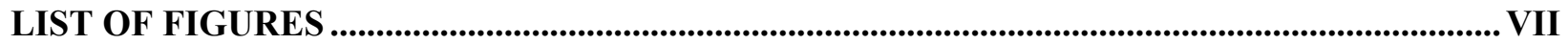

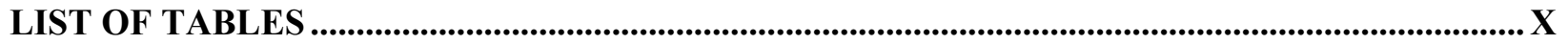



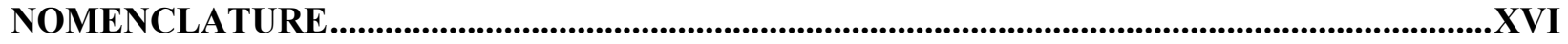

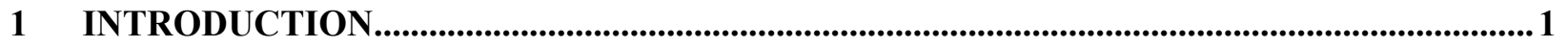

1.1 ENERGY USE IN COMMERCIAL BUILDINGS IN THE UNITED STATES....................................... 2

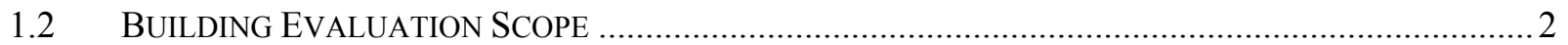

1.3 HIGH-PERFORMANCE BUILDINGS RESEARCH OBJECTIVES ..................................................... 2

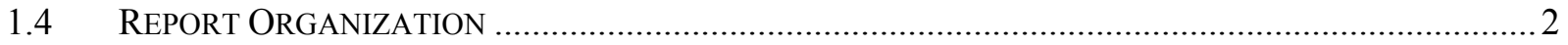

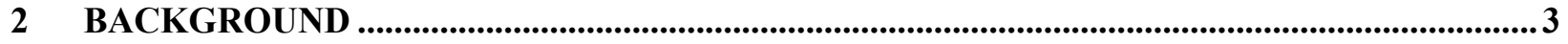

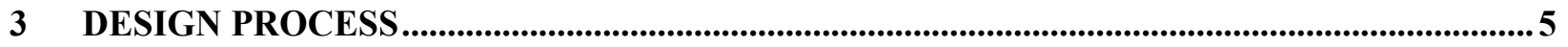

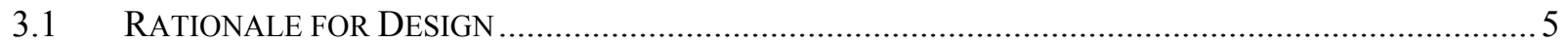

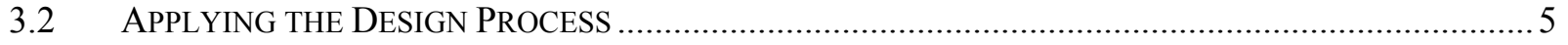



3.2.2 Step 2: Create a base-case building model.......................................................... 8

3.2.3 Step 3: Parametric Analysis............................................................................... 10

3.2.4 Step 4: Design Solutions to Reduce Energy Consumption .................................. 11

3.2.5 Step 5: Simulate Performance of Design Solutions ........................................... 12

3.2.6 Step 6: Conceptual Design................................................................................... 13

3.2.7 Step 7: Design Development ............................................................................ 15

3.2.8 Step 8: Bid Documents and Specifications ..................................................... 17



3.2.10 Step 10: Commissioning and Postoccupancy Evaluation .................................... 18

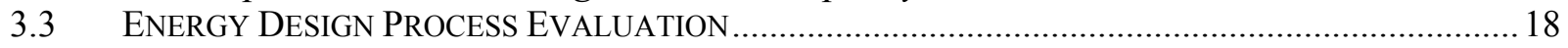

3.3.1 Energy Design Process Questionnaire Methods .............................................. 18

3.3.2 Energy Design Process Questionnaire Results............................................... 19

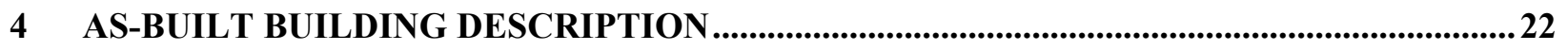

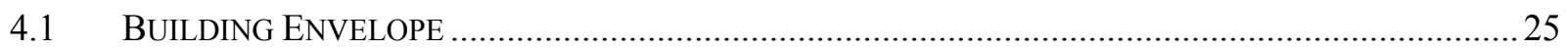

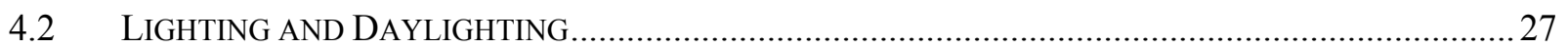

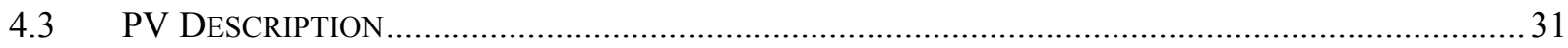

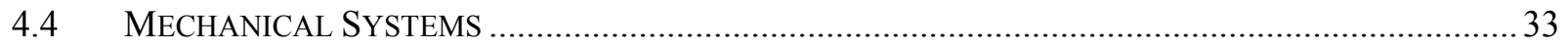

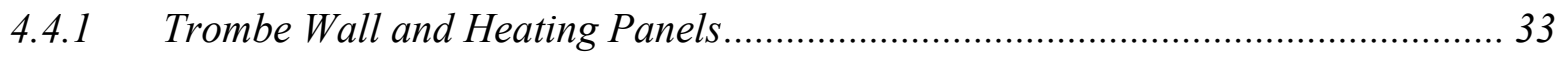

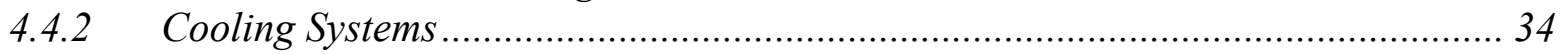

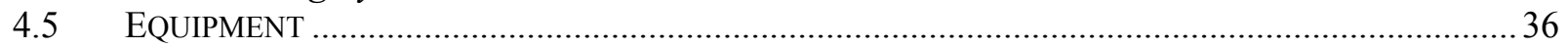

5 WHOLE-BUILDING ENERGY EVALUATION .......................................................................38

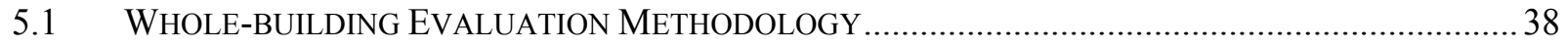

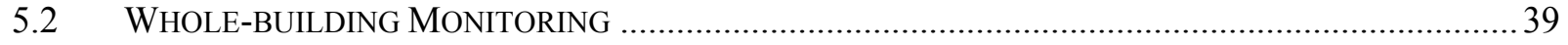






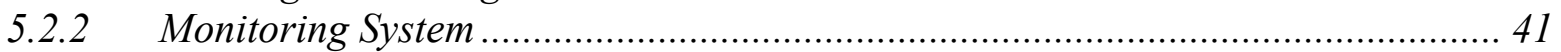

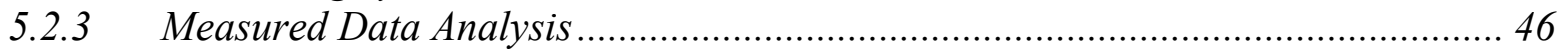

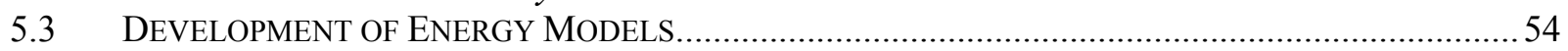

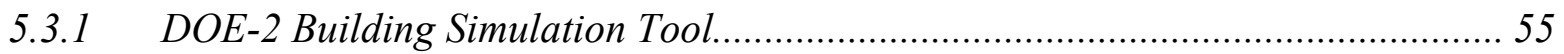

5.3.2 Development of the Base-Case Model ............................................................... 55

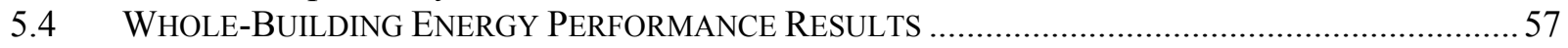

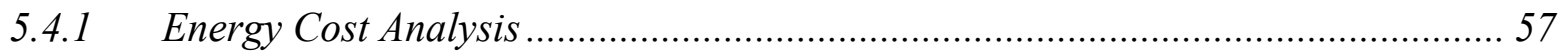

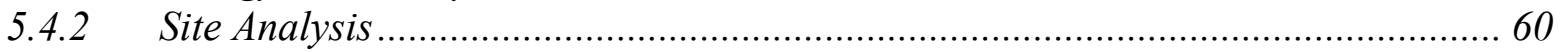

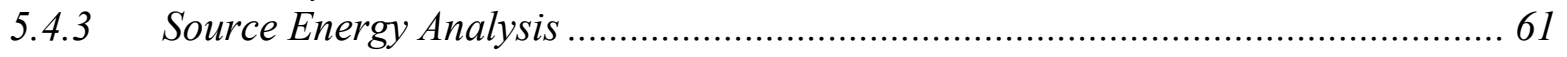

6 SUBSYSTEM EVALUATIONS ...............................................................................................6

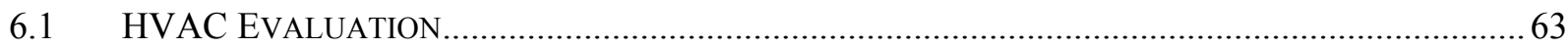



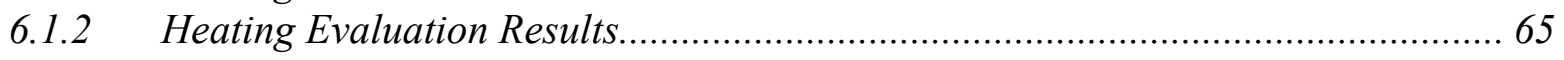

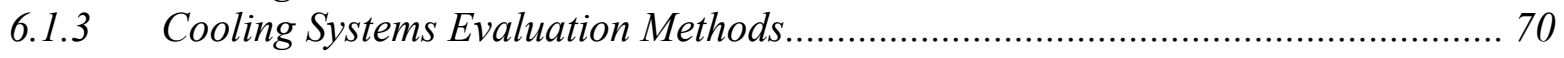

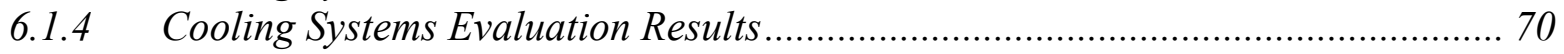

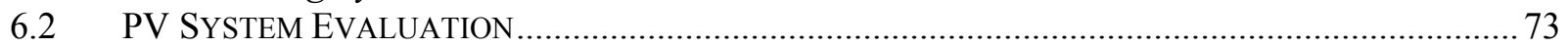

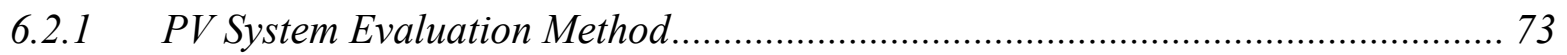

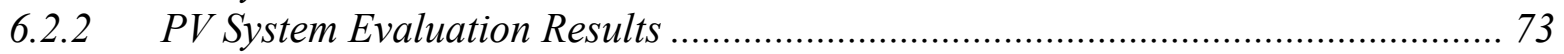

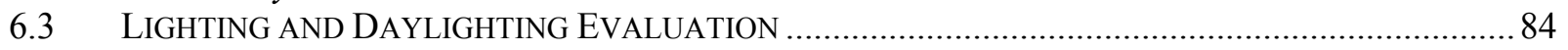

6.3.1 Lighting and Daylighting Evaluation Methods................................................... 84

6.3.2 Lighting and Daylighting Evaluation Results................................................. 86

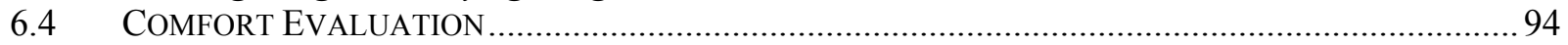

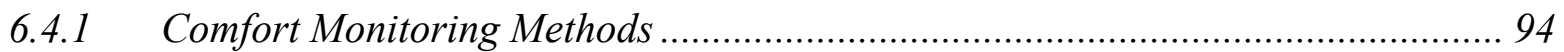

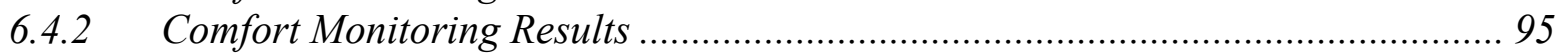

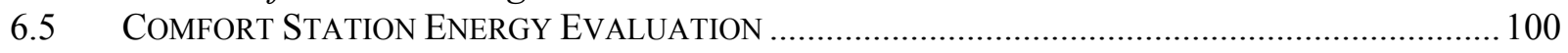

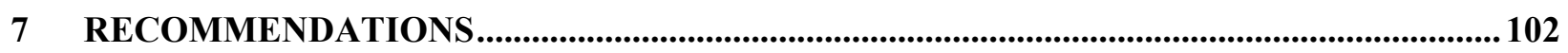

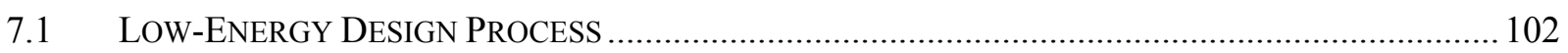

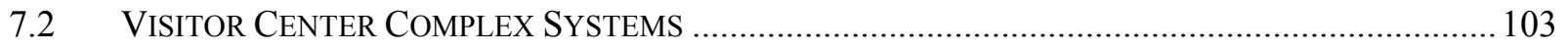

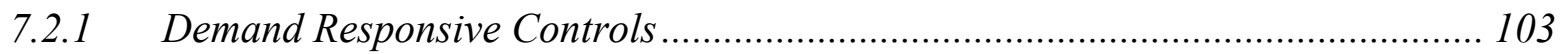



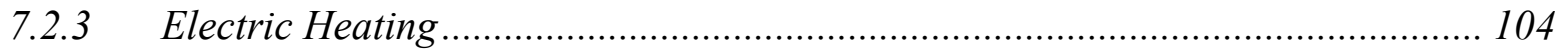

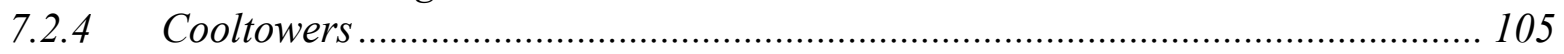

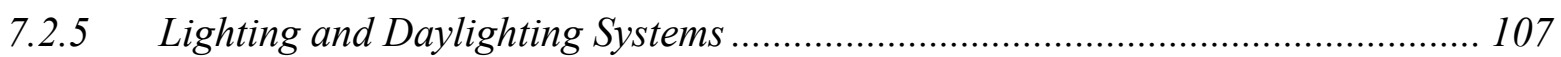

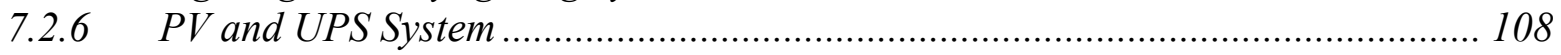

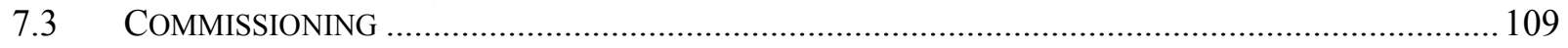

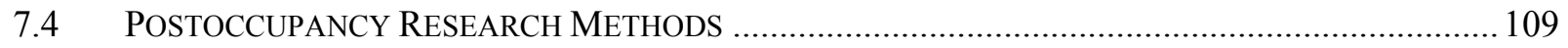

8 CONCLUSIONS ......................................................................................................................111

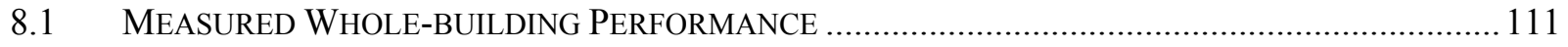

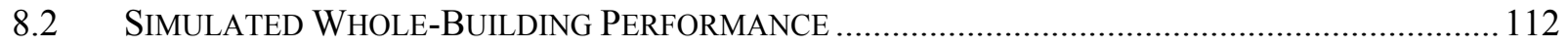

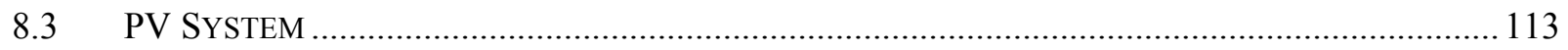

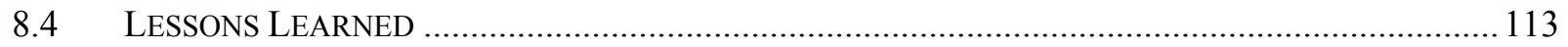

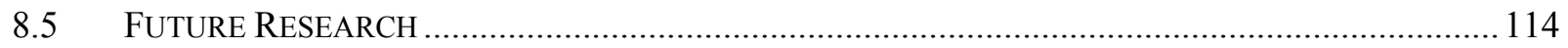

9 REFERENCES........................................................................................................................ 115 
APPENDIX A THE LOW-ENERGY DESIGN PROCESS ......................................................117

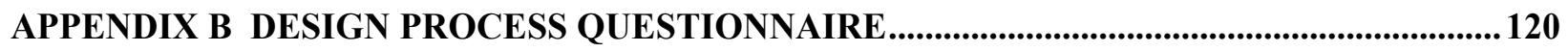

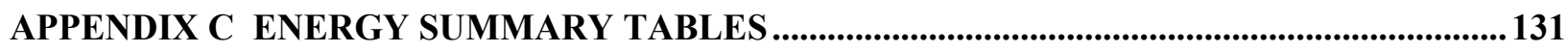

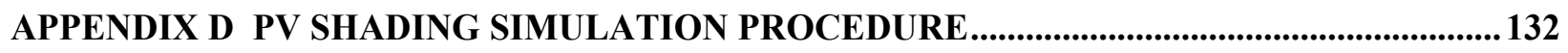

APPENDIX E EXTENDED HVAC AND COMFORT ANALYSIS............................................ 135

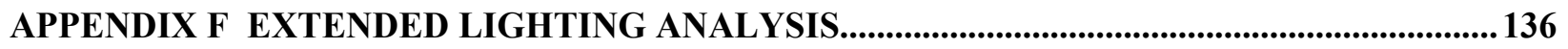

APPENDIX G LIST OF PEOPLE INVOLVED IN PROJECT ....................................................... 137 


\section{List of Figures}

Figure ES-1 Comparison of base-case model using recorded weather data to measured energy

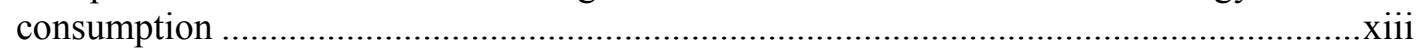

Figure ES-2 1999 Western U.S. site energy intensity by building type, with ZNP Complex average...xiv Figure 2-1

Figure 3-1

Figure 3-2

Figure 3-3

Figure 3-4

Figure 3-5

Figure 3-6

Figure 3-7

Figure 3-8

Figure 3-9

Figure 3-10

Figure 4-1

Figure 4-2

Figure 4-3

Figure 4-4

Figure 4-5

Figure 4-6

Figure 4-7

Figure 4-8

Figure 4-9

Figure 4-10

Figure 4-11

Figure 4-12

Figure 4-13 1999 Energy Use and Costs by Building Type for Western U.S. (EIA 2002) ...................... 3

Summer traffic congestion, traffic back-ups, and parking issues ..................................... 5

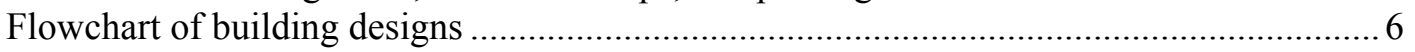

Typical monthly average daily weather for ZNP ........................................................ 8

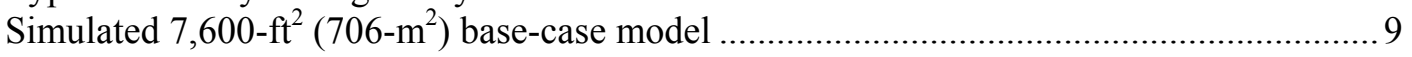

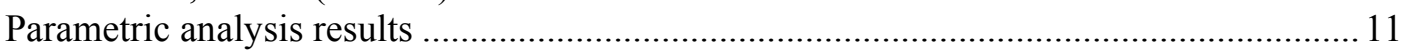

Diagram of energy design solutions for the Visitor Center Complex ............................... 12

Initial proposed design of the Visitor Center................................................................... 14

Conceptual design floor plan for Visitor Center and Comfort Station (Step 6) ................... 14

Simulated energy cost savings of base-case building compared to conceptual design

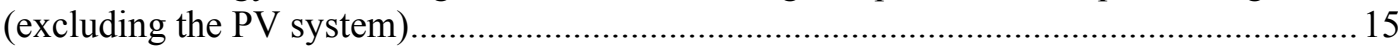

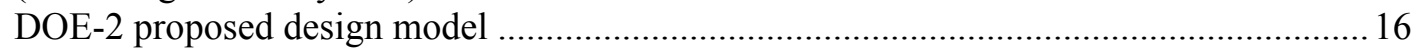

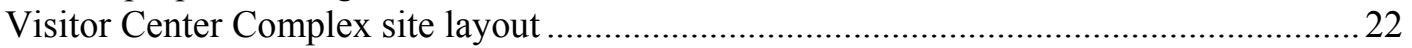

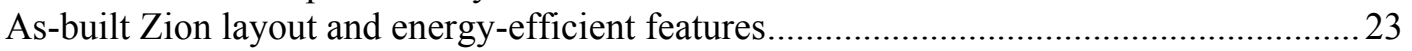

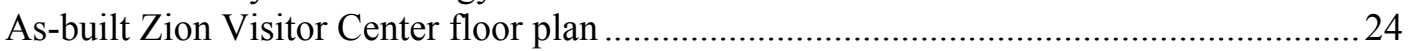



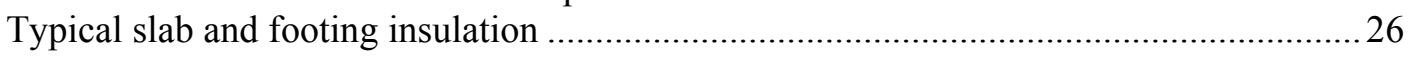

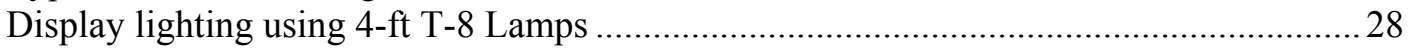

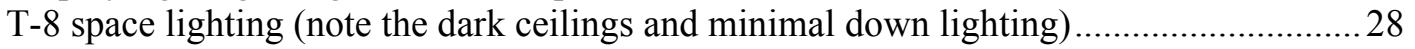

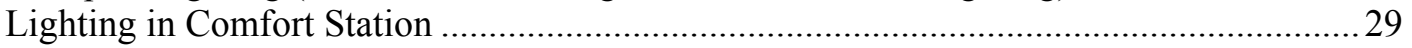

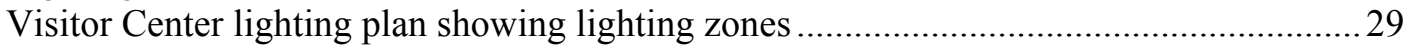

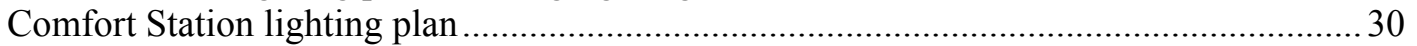



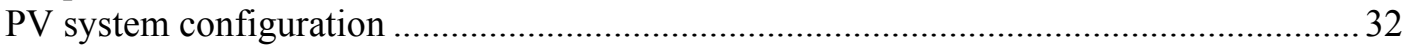

Figure 4-14 Photograph of Trombe wall showing patterned glass over the Trombe wall, row of daylighting glass, and overhang to shade wall during the summer ......................................34

Figure 4-15 Illustration of how the cooltowers work at the Visitor Center ........................................ 35

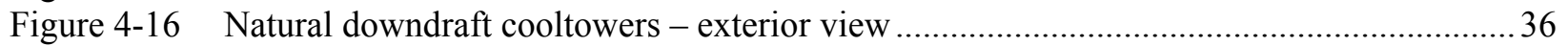

Figure 4-17 Interior view of a cooltower showing operable shutters that allow cool air to enter the

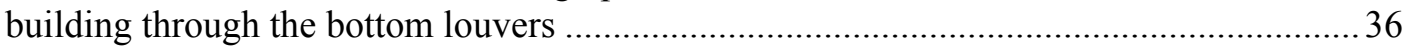

Figure 5-1 Timeline of monitoring system and postoccupancy energy evaluation.............................3 38

Figure 5-2 One-line electrical system plan and data acquisition meter locations ............................... 40

Figure 5-3 Verification of utility and measured data, November 2001 to February 2003 ..................44

Figure 5-4 Comparison of average monthly outdoor temperatures for Complex and Cedar City ........ 45

Figure 5-5 End use daily average monthly consumption, November 2001 through May 2003............46

Figure 5-6 Energy consumption by end use, November 2001 through October 2002 ......................... 47

Figure 5-7 Peak demand day without demand limiting controls, February 2, 2002 ..........................4 48

Figure 5-8 Typical heating profile with demand limiting controls, February 8, 2003 .......................50

Figure 5-9 Average daily site energy purchased for heating, cooling, and hot water and PV production, Winter 2001-2002 compared to Winter 2002-2003 .......................................51

Figure 5-10 Visitor Center and Comfort Station peak demand analysis and time of occurrence for each

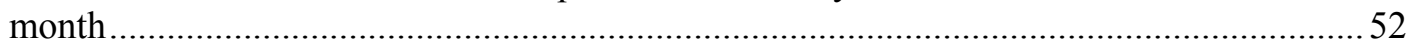

Figure 5-11 Whole-building evaluation flowchart: as-built building and base-case model..................55

Figure 5-12 Visitor Center Complex energy costs, Nov. 2001 through May 2003 ..............................58 
Figure 5-13

Figure 5-14

Figure 6-1

Figure 6-2

Figure 6-3

Figure 6-4

Figure 6-5

Figure 6-6

Figure 6-7

Figure 6-8

Figure 6-9

Figure 6-10

Figure 6-11

Figure 6-12

Figure 6-13

Figure 6-14

Figure 6-15

Figure 6-16

Figure 6-17

Figure 6-18

Figure 6-19

Figure 6-20

Figure 6-21

Figure 6-22

Figure 6-23

Figure 6-24

Figure 6-25

Figure 6-26

Figure 6-27

Figure 6-28

Figure 6-29

Figure 6-30

Figure 6-31

Figure 6-32

Figure 6-33

Figure 6-34

Figure 6-35

Figure 6-36

Figure 6-37

Figure 6-38

Figure 6-39

Figure 8-1

Figure 8-2

Base-case and energy costs, November 2001 through October 2002

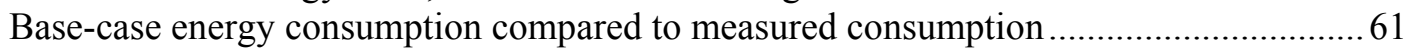

Histogram of outdoor dry-bulb temperatures during occupied hours .................................63

HVAC energy consumption as a function of outdoor temperature ....................................64

Cross section of Trombe wall showing location of temperature sensors ...........................65



Infrared picture of Trombe wall during heating season 2/9/2000 at 6:00 p.m. ...................67 67

Verification of middle Trombe wall temperature after adjusting thermal conductivity ...... 68

Trombe wall and heating system performance, 2001-2002 heating season.......................69

Trombe wall temperature transients over a 24-hour period.............................................. 70

Water consumption versus daily average outdoor temperature (Summer 2002)................. 71

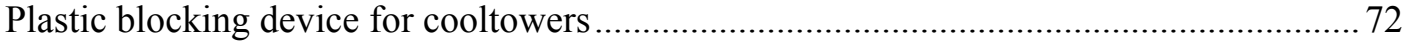

Average hourly AC power profile by month for PV production, November 2001 through

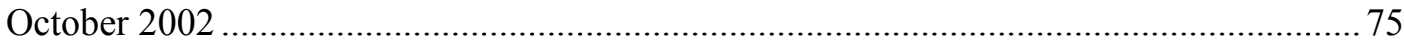

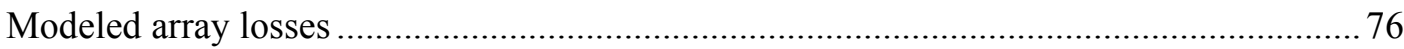

Sandia PV performance model I-V curve tracer model for the Zion PV system .................77

PV production for unshaded, horizon shaded, and horizon and tree shaded simulations.... 78

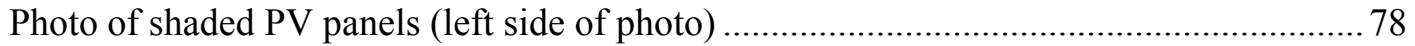

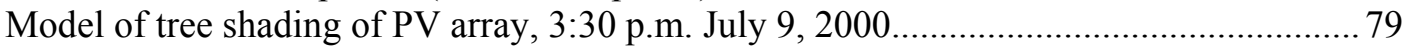

Simulated power-voltage curve traces for summer weather conditions ............................ 80

Simulated power-voltage curve traces for winter weather conditions................................. 81

Simulated annual PV production: Best fixed voltage, actual fixed voltage, and maximum



Simulated annual PV production comparisons.............................................................. 82

Voltage and real power of emergency panel versus time for a utility grid power outage ... 84

Continuous and handheld illuminance measurement locations.......................................... 86

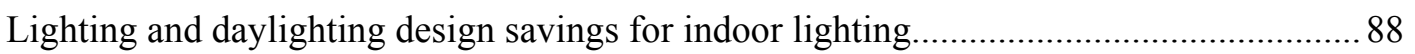

Measured, base case, and actual LPD annual lighting consumption profiles and savings

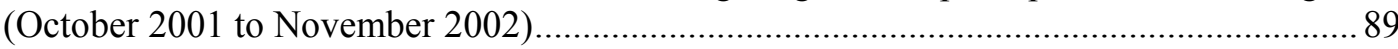

Measured bookstore and outdoor illuminance levels, July 12, September 22, and

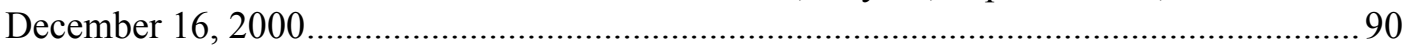

NPS bookstore checkout counter glare from clerestories........................................... 91

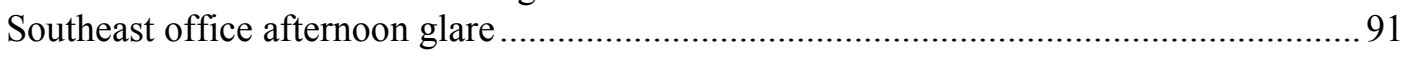

Illuminance points over the floor plan from electrical lights without daylighting on

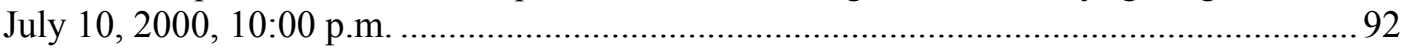

Illuminance points across floor plan for a clear sky with lights on; July 11, 2000 at

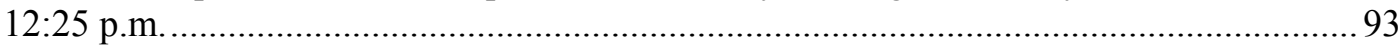

Illuminance points across floor plan for a partly cloudy sky with lights on as normal;



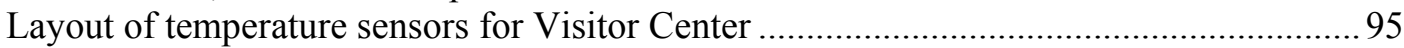

Histogram of winter average temperature in the Visitor Center.........................................96

Histogram of hours at average temperature in the Visitor Center during summer.............. 97

Visitor Center Zone 2 comfort histogram during summer .............................................98

Zone 7 exterior door temperatures averaged over October 8, through October 19, $2001 \ldots 99$

Infrared picture of the interior door in Zone 7, August 18, 2001 12:35 p.m..................... 99

Comfort Station end use monthly consumption per day, November 2001 through October

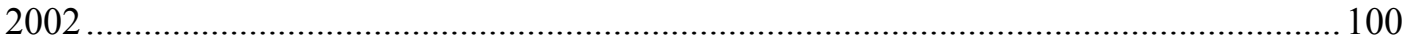

Histogram of hours at average temperature in the Comfort Station during winter ........... 101

Histogram of hours at average temperatures in the Comfort Station during summer ....... 101

End use daily average monthly consumption, November 2001 through May 2003.......... 111

Annual performance comparison ..................................................................................... 112 
Figure B-1 Summary of measured and base-case energy use.

Figure D-1 Photo of Visitor Center looking south showing southern horizon (canyon walls) accounted for in simulations.

Figure D-2 Horizontal insolation monthly profile, October 2001 through October 2002

Figure D-4 Tree shading of PV array, 3:30 p.m. July 09, 2000. 


\section{List of Tables}

Table ES-1 Cost, Site, and Source Energy Summary, Nov. 2001 to Oct. 2002 ....................................xiii

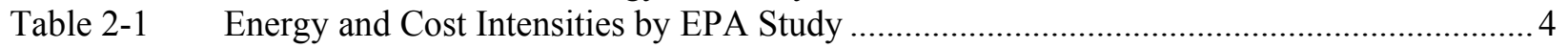

Table 3-1 Base-Case Model Characteristics .................................................................... 9

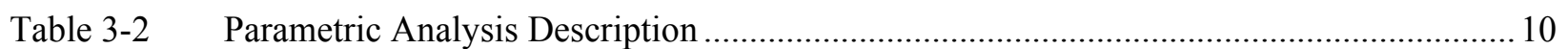

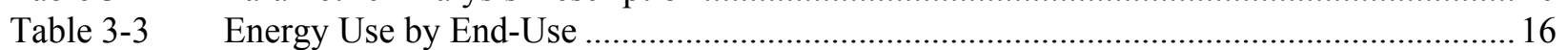

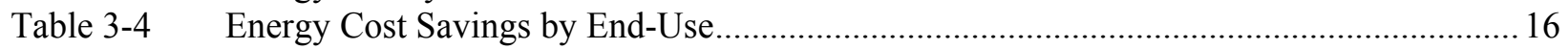

Table 4-1 Differences between Proposed Design and As-Built Design ...........................................2 23

Table 4-2 Building Envelope Construction and Thermal Properties ...............................................22

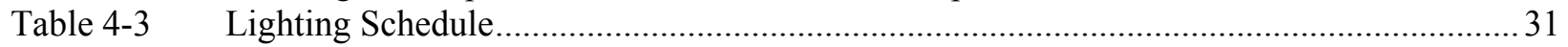

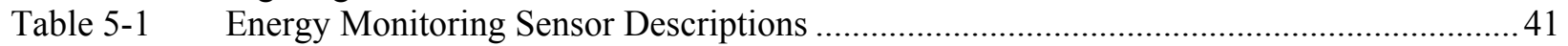



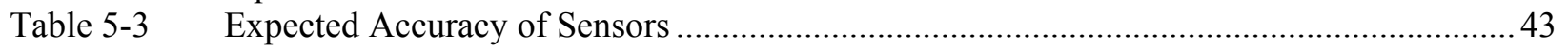

Table 5-4 Heating and Cooling Degree Days for Cedar City and Zion.......................................... 44

Table 5-5 Energy Use and Intensity for Each Building, Nov. 2001 to Oct. 2002 .......................... 47

Table 5-6 PV Contribution during Peak Demands .....................................................................52

Table 5-7 Information on Demand Occurrences and Reasonability ..............................................53

Table 5-8 As-Built Design and Base-Case Comparisons ...........................................................56

Table 5-9 Visitor Center Complex Energy Costs, Nov. 2001 through May 2003 .............................57

Table 5-10 Base-Case and Measured Site Annual Consumption and Savings ....................................60



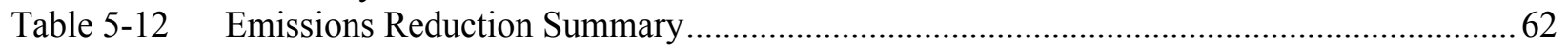

Table 6-1 Heating and Cooling Degree Days for 2001-2002 and 2002-2003 Data .........................63

Table 6-2 PV Performance: November 1, 2001 through October 31, 2002 ...................................74

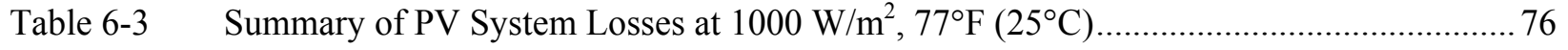



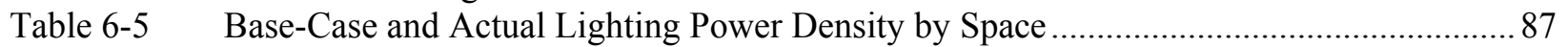

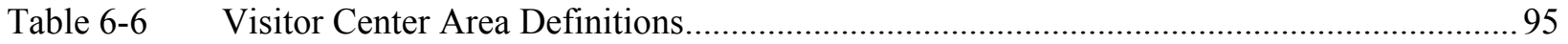

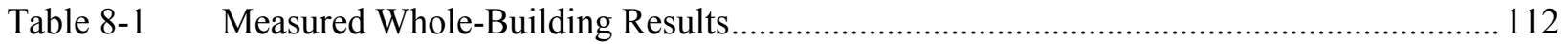

Table 8-2 Cost, Site, and Source Energy Savings, Nov. 2001 to Oct. 2002 ................................... 113 


\section{Executive Summary}

\section{Introduction}

Zion National Park (ZNP) in southwestern Utah has experienced substantial growth in visitors over the last two decades. To reduce environmental impact and improve visitor experience, National Park Service (NPS) staff undertook the planning and development of a new Visitor Center Complex and an alternative transportation system with the gateway community of Springdale. NPS staff wanted their new complex to complement the natural beauty of ZNP and had a strong design goal of minimizing energy and environmental impact. To help achieve their energy goals, the NPS requested technical support from the National Renewable Energy Laboratory's (NREL's) Center for Buildings and Thermal Systems. The collaboration between the NPS and NREL lasted throughout the duration of the project from predesign through postoccupancy. The result was a building with $67 \%$ less energy costs than a comparable building that just meets the applicable energy code. In addition, construction costs were similar to comparable conventional visitor center building in a national park. The facility opened in May 2000 and includes an $8,800-\mathrm{ft}^{2}\left(817-\mathrm{m}^{2}\right)$ Visitor Center (with interpretative displays, offices, and retail space for the Zion Natural History Association and a 2,756- $\mathrm{ft}^{2}\left(256-\mathrm{m}^{2}\right)$ Comfort Station (restrooms). This Visitor Center Complex is an example of a high-performance building that demonstrates what is possible when an aggressive approach is used for achieving extraordinary levels of energy efficiency. Energy features of the building include: passive direct evaporative cooling, natural ventilation, external shading devices and glazing designed for solar load avoidance in summer and passive solar gain in winter, thermal mass sized for the direct gain system, noncirculating Trombe wall, daylighting, photovoltaic uninterruptible power, and digital controls to integrate energy operations.

\section{Research Goals and Approach}

This report is part of a series of six case studies to develop, document, analyze, and evaluate the processes by which highly energy-efficient buildings can be reliably produced. In this project, NREL was able to test the 10-step low-energy design process that we had previously developed and are continuing to refine (Torcellini et. al. 1999). This process covers predesign through postoccupancy, relies heavily on building energy simulation, and also includes other important qualitative and quantitative features such as design charrettes with all members of the design team, and the establishment of energy goals through the use of computer modeling. It would not have been possible for NREL to conduct this research without close collaboration with real building design and construction projects. It is not practical to use classical controlled repeatable experimental techniques for objects as large and complex as commercial buildings, and for design and construction processes that of necessity involve so many different players over an extended period.

Specifically, the objectives of this project were to:

- evaluate the low-energy design process as applied to the Visitor Center Complex,

- use careful metering, submetering, and simulation techniques to evaluate the whole-building energy performance during normal operation and determine if the original low-energy design goals were met,

- determine lessons learned from designing, constructing, operating, and monitoring the Visitor Center Complex for use in future projects, and

- investigate opportunities for improving the operating performance of the Visitor Center Complex. 
For its energy performance analysis, NREL collected detailed monitoring data from the Building Automation System in each building. In addition to monitoring, researchers had access to the control system and developed custom algorithms to operate systems. The overall energy savings of the building indicate the design process was successful. The few shortcomings in the project can be traced to construction changes that were installed before they could be analyzed or to design changes that occurred without the opportunity for proper analysis by the NREL energy specialists.

\section{Energy Design Concepts}

Part of the success of the project was a commitment to climate-sensitive design starting in the predesign stage. The initial predesign activities included a set of on-site charrettes that allowed the design team to become familiar with the unique terrain and climate features of the site. It was apparent from the site visit that the local microclimate provided many ideas for the design concepts that could be used to provide comfort in and around the visitor center. The Virgin River canyon controlled many aspects of the microclimate. The narrow canyon walls, splashing water, and vegetation at the riverbanks provided shade and evaporatively cooled air in sharp relief to the aridness and extreme heat. In some places, seeps wetted the canyon walls, creating a cooling effect. In other places, the seeps nourished blooms of wet moss that behave much as the wetted media in a commercial evaporative cooler. The overall geometry of the canyon, which was deep and narrow up-river of the site and widened progressively in the down-river direction, created a diurnal chimney effect with up canyon winds from about noon to midnight and down canyon winds from midnight to noon. The lighting in the narrow parts of the canyon was diffuse with a pleasant contrast ratio and without the unpleasant impact of the direct sun. A winter visit was also informative with solar heating of exposed canyon mass surfaces often adequate to provide outside comfort during the day.

Thus were born many of the overall energy, lighting and human comfort architectural design concepts for the complex. These are summarized as follows:

- Create a shaded microclimate around the buildings in summer and solar exposure in winter with plantings of deciduous trees and overhead arbors.

- Provide irrigation throughout the space with small irrigation canals similar to the historic ones found in the canyon. Although not implemented in this project, it is possible to use porous patio materials to create an evaporatively cooled walking surface.

- Create passive evaporative downdraft cooltowers to cool the building without the need for blowers or vapor compression equipment.

- Use the diurnal winds to help drive a natural ventilation system and to boost the cooltower's air delivery with wind pressure.

- Control automated clerestory windows and the cooltowers with the building automation system to create an integrated, controllable natural cooling system.

- Specify the thermal and optical properties of glass; size and orient windows and shading devices to provide diffuse light with minimal solar load in summer, and light and solar heat in winter.

- Use massive building materials on the interior to modulate temperature swings and store solar heat in winter and cool night air in summer.

- Construct noncirculating Trombe walls on the south face of the buildings for additional passive heating with a time delay into the late afternoon and evening hours.

- Allow enough south-oriented pitched roof surface to accommodate photovoltaic panels so that the building can operate effectively and comfortably despite frequent summer power outages. 


\section{Results}

NREL compared monitored energy performance results to base-case building energy models using the same weather files. Our criterion for quantifying performance throughout the project was energy cost. From November 2001 through October 2002, the annual energy costs for the Visitor Center Complex were $\$ 5,094 / \mathrm{yr}$ or $\$ 0.43 / \mathrm{ft}^{2} \cdot \mathrm{yr}\left(\$ 4.63 / \mathrm{m}^{2} \cdot \mathrm{yr}\right)$, net site energy use was $85,000 \mathrm{kWh} / \mathrm{yr}$ or $24.7 \mathrm{kBtu} / \mathrm{ft}^{2} \cdot \mathrm{yr}$ $\left(280.5 \mathrm{MJ} / \mathrm{m}^{2} \cdot \mathrm{yr}\right)$ and source energy intensity was $80 \mathrm{kBtu} / \mathrm{ft}^{2} \cdot \mathrm{yr}\left(908.5 \mathrm{MJ} / \mathrm{m}^{2} \cdot \mathrm{yr}\right)$. Photovoltaic panels produced $7,900 \mathrm{kWh} / \mathrm{yr}$ or $8.5 \%$ of the total site energy use. The base-case energy model, based on ASHRAE Standard 90.1, yielded energy costs of $\$ 15,250 / \mathrm{yr}$ or $\$ 1.30 / \mathrm{ft}^{2} \cdot \mathrm{yr}\left(\$ 13.99 / \mathrm{m}^{2} \cdot \mathrm{yr}\right)$; site energy use was $241,800 \mathrm{kWh} / \mathrm{yr}$ or $70.3 \mathrm{kBtu} / \mathrm{ft}^{2} \cdot \mathrm{yr}\left(798 \mathrm{MJ} / \mathrm{m}^{2} \cdot \mathrm{yr}\right)$, translating to a source energy intensity of $227 \mathrm{kBtu} / \mathrm{ft}^{2} \cdot \mathrm{yr}\left(2,580 \mathrm{MJ} / \mathrm{m}^{2} \cdot \mathrm{yr}\right)$. This data represents savings (including receptacle loads) of $67 \%$ for energy cost, $62 \%$ for site energy, and 65\% for source energy (see Figure ES-1 and Table ES-1). When we implemented controls to reduce demand charges, average daily peak demand in winter declined by almost $50 \%$.

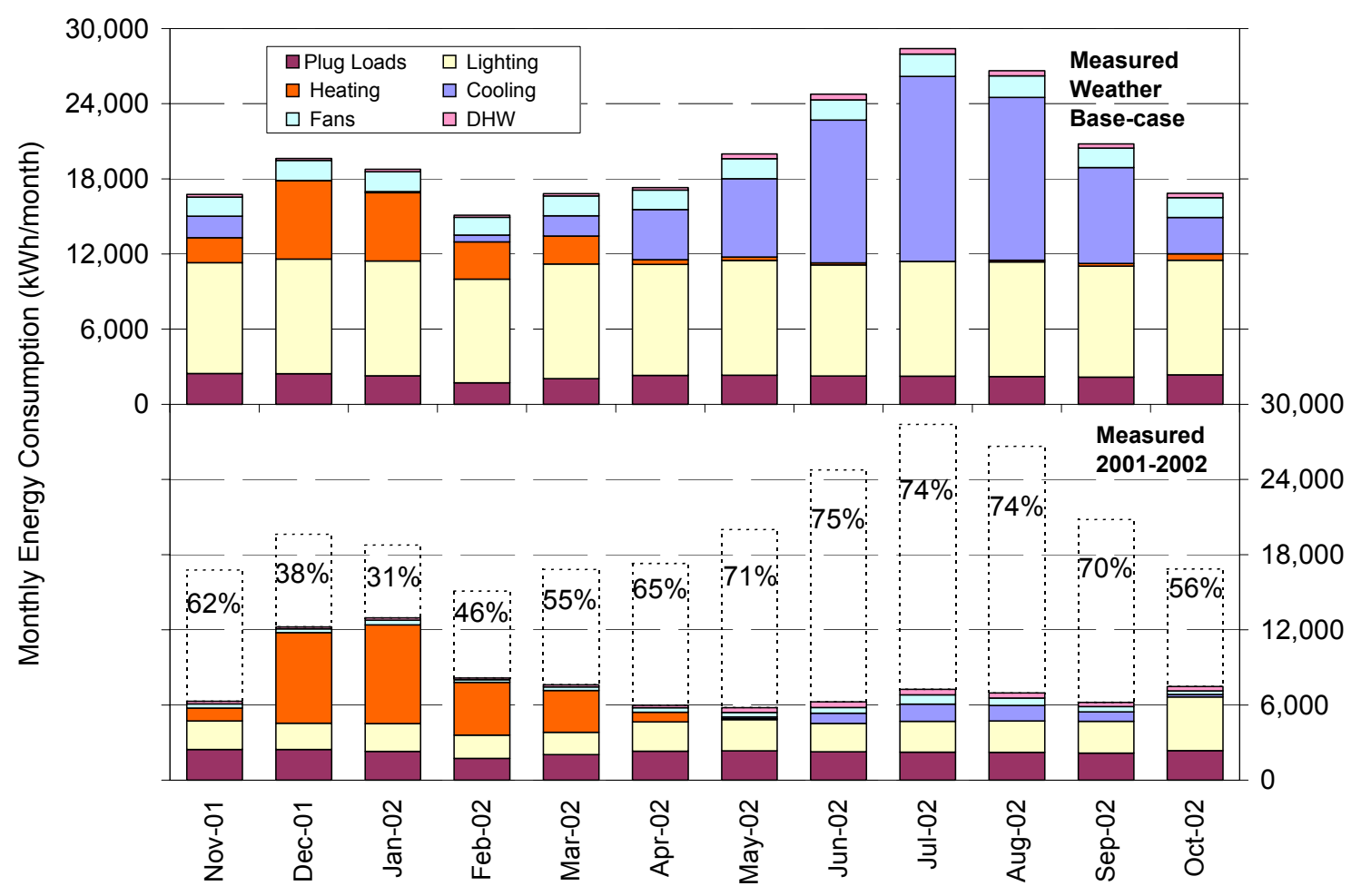

Figure ES-1 Comparison of base-case model using recorded weather data to measured energy consumption

Table ES-1 Cost, Site, and Source Energy Summary, Nov. 2001 to Oct. 2002

\begin{tabular}{|c|c|c|c|c|c|c|}
\hline & \multicolumn{2}{|c|}{ Cost } & \multicolumn{2}{|c|}{ Site Energy } & \multicolumn{2}{|c|}{ Source Energy } \\
\hline & $\begin{array}{c}/ \mathrm{ft}^{2} \cdot \mathrm{yr} \\
\left(\$ / \mathrm{m}^{2} \cdot \mathrm{yr}\right)\end{array}$ & $\begin{array}{l}\text { Percent } \\
\text { Savings }\end{array}$ & $\begin{array}{l}\mathrm{kBtu} / \mathrm{ft}^{2} \cdot \mathrm{yr} \\
\left(M J / \mathrm{m}^{2} \cdot \mathrm{yr}\right)\end{array}$ & $\begin{array}{l}\text { Percent } \\
\text { Savings }\end{array}$ & $\begin{array}{l}\mathrm{kBtu} / \mathrm{ft}^{2} \cdot \mathrm{yr} \\
\left(\mathrm{MJ} / \mathrm{m}^{2} \cdot \mathrm{yr}\right)\end{array}$ & $\begin{array}{l}\text { Percent } \\
\text { Savings }\end{array}$ \\
\hline Base-case & $\begin{array}{c}1.30 \\
(\$ 13.99)\end{array}$ & \multirow{2}{*}{$67 \%$} & $\begin{array}{c}70.3 \\
(799)\end{array}$ & \multirow{2}{*}{$62 \%$} & $\begin{array}{c}227 \\
(2,580)\end{array}$ & \multirow{2}{*}{$65 \%$} \\
\hline As-built & $\begin{array}{c}\$ 0.43 \\
(\$ 4.63)\end{array}$ & & $\begin{array}{c}27.0 \\
(307)\end{array}$ & & $\begin{array}{c}80 \\
(910)\end{array}$ & \\
\hline
\end{tabular}


The Visitor Center Complex is a combination of office, retail, and service areas. Figure ES-2 compares measured energy use of the Visitor Center Complex with other types of commercial buildings in the western United States (EIA 2002), with the Visitor Center Complex energy use equivalent to a warehouse.

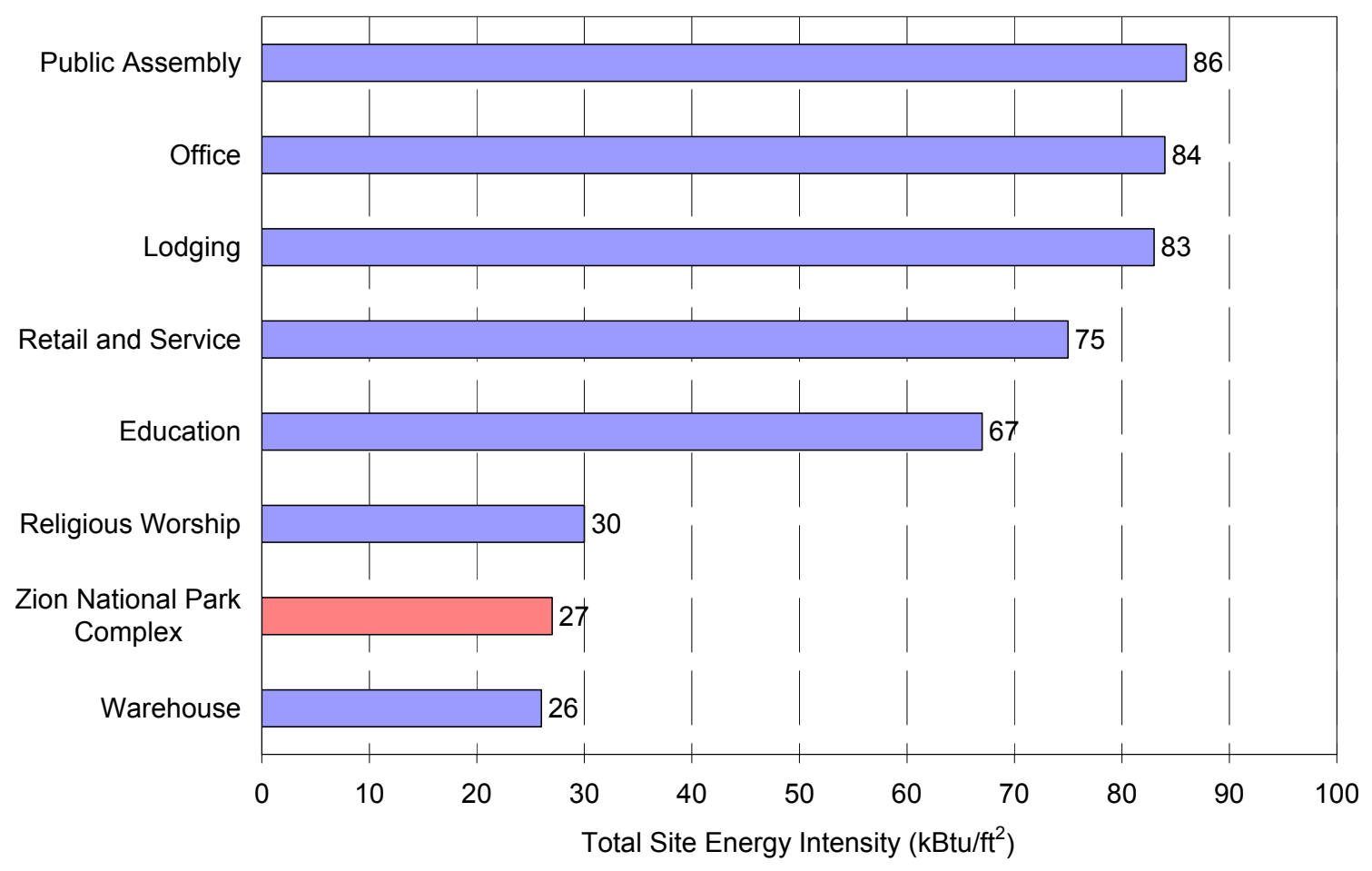

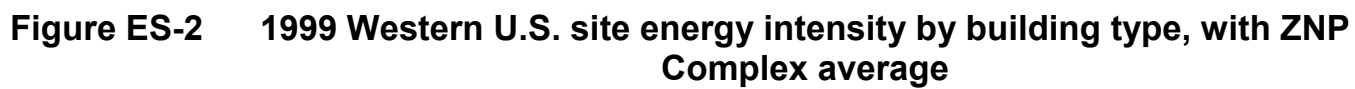

Our experiences with the Visitor Center Complex project, from early conceptual design through three years of postoccupancy monitoring, led to the following major conclusions:

- A multiple-use commercial building that includes retail, office, and public assembly spaces can be constructed to use $65 \%$ less energy than an equivalent, minimally code-compliant building.

- The Visitor Center Complex project was successful because:

- The design team set appropriate energy performance goals early in the process and committed to achieve them.

- The entire design team was involved throughout all phases of the project.

- We used energy simulation models to predict energy performance of options and alternatives throughout the design process.

- The energy performance of the building was continuously monitored and the information was used to evaluate and improve the performance.

- Building controls can substantially reduce the electrical demand and related charges. 
- For the climate and scale of the Visitor Center Complex, it is possible to eliminate mechanical air systems and use simple localized heating systems to augment passive heating and cooling to provide occupant thermal comfort.

- Cooltowers can effectively combine direct evaporative cooling and passive natural ventilation and deliver comfort comparable to mechanical direct evaporative cooling using minimal energy.

- Daylighting can effectively augment electric lighting in retail spaces as well as reducing cooling loads.

- Solar-electric uninterruptible power systems can add substantial value to buildings in areas with poor power reliability.

- Visitor Center heating is the largest single end use, with plug loads and lighting the next most energy intensive loads.

- The building uses very little energy for heating and cooling when the outdoor temperature is between $60^{\circ} \mathrm{F}$ and $75^{\circ} \mathrm{F}\left(15.6^{\circ} \mathrm{C}\right.$ and $\left.23.9^{\circ} \mathrm{C}\right)$.

- Contractors required training on installing energy efficiency and renewable energy technologies (especially insulation).

- Maintenance staff should be involved throughout the design phase.

- The contractor must be involved as part of the design team, even when a more complex designbid-build process is involved.

- Changes in rate structures can change the design decisions and operating strategies.

- Commercial buildings may shift from being cooling dominated to heating dominated because of low-energy design.

For this project, we evaluated the as-built building energy performance as well as the effect of the lowenergy design process on energy performance. Even though the building performs well overall, we found it could have performed much better had the low-energy design process been followed more carefully. 


\section{Nomenclature}

Commonly used terms in this report are defined below.

- Building Automation System (BAS) - the central computer used to control HVAC equipment and lighting. We also used the BAS to collect most data used in this analysis.

- Proposed design - the proposed initial design was an " " shaped building $\left[7,600 \mathrm{ft}^{2}\left(710 \mathrm{~m}^{2}\right)\right]$ with a separate building for restrooms $\left[1,560-\mathrm{ft}^{2}\left(145 \mathrm{~m}^{2}\right)\right]$. Exhibits are located outdoors.

- Proposed base case - The base-case model corresponding to the proposed design. It is a 7,600- $\mathrm{ft}^{2}$ $\left(710-\mathrm{m}^{2}\right)$ solar neutral building with a square footprint. It is used as the benchmark to calculate the potential energy performance savings of the proposed design.

- As-built design - the design as modified to reflect changes made during construction. This model represents the building as it was built, including a separate building for restrooms and outdoor exhibits to minimize floor area. Schedules are based on actual operation as measured. The design consists of a Visitor Center and Comfort Station.

- $\quad$ Base case - The base-case model corresponding to the as-built design. It is an $11,726-\mathrm{ft}^{2}(1090$ $\mathrm{m}^{2}$ ) solar neutral building with a square footprint used as the benchmark to calculate energy performance savings. Schedules are the same as the as-built design.

- Visitor Center Complex - The three buildings that make up the Visitor Center Complex defined here as Visitor Center, Comfort Station (public restrooms), and Fee Station. Parking lot lights are included in the energy use when the Complex is discussed in this report. The Fee Station building, although not part of the study, is included in the Visitor Center Complex because the utility meters include power from this building.

- Visitor Center - an 8,800- $\mathrm{ft}^{2}\left(818-\mathrm{m}^{2}\right)$ building in the Visitor Center Complex that contains the bookstore, offices, and NPS ranger contact counters.

- Comfort Station - a 2,756- $\mathrm{ft}^{2}\left(256-\mathrm{m}^{2}\right)$ building in the Visitor Center Complex that contains the restroom facilities

- Fee Station - a $170-\mathrm{ft}^{2}\left(15.8-\mathrm{m}^{2}\right)$ building in the Visitor Center Complex that is used to collect fees for incoming visitors. This building was not part of the research project and was not explicitly evaluated. However, the utility meter includes the power from this building.

- Energy costs - the cost of energy needed to operate the building. The Visitor Center Complex only had electricity available at the site. The energy costs include fixed charges, energy use charges, and demand charges.

- Construction costs - the amount of money needed to construct the building. 


\section{Introduction}

Zion National Park (ZNP) is located in a canyon in southwestern $\mathrm{Utah}^{1}$. The area is arid, only receiving 15 inches of precipitation per year (NPS 2003). The location is characterized by sunny days with low humidity. During the summer, temperatures can reach $100^{\circ} \mathrm{F}\left(38^{\circ} \mathrm{C}\right)$ or higher. Winters are relatively mild with only about 3500 base 65 degree-days. In summer, ZNP hosts as many as 3,000 visitors an hour. To reduce visitor impact on resources and to improve visitor experiences, ZNP undertook the planning and development of an alternative transportation system with the gateway community of Springdale. As a part of the transportation system, several visitor facilities were constructed to make up a Visitor Center Complex that consisted of a small building where Park rangers collected visitor fees, a retail/interpretive area, and public restrooms. The National Park Service (NPS) decided to pursue an innovative building for the Visitor Center Complex - one with an aggressive energy reduction goal. Other important issues to the NPS were that the building:

- blended well with the surrounding canyon walls,

- mirrored the existing historic architecture of the park,

- offered continued enjoyment for many generations of people (100 years or longer),

- reduced environmental impact to the surrounding natural environment,

- operated during frequent power outages, and

- presented a model for other NPS facilities.

Although budgetary limits were important, they were considered within the context of a building that had to be constructed in a remote place and be extremely durable to withstand the heavy pedestrian traffic for at least 100 years. These requirements are unique to NPS architecture. Nevertheless, some of the energy design solutions were able to reduce construction costs as discussed in the design section of this report.

NPS worked with the National Renewable Energy Laboratory (NREL) to create the plans for the new Visitor Center Complex and transportation system. Objectives for NREL's involvement were established early in the process. This report documents the results of this work. NREL's objectives were to:

- evaluate the low-energy design process as applied to the Zion Visitor Center Complex,

- use careful metering, submetering, and simulation techniques to evaluate the whole-building energy performance during normal operation and determine if the original low-energy design goals were met,

- determine lessons learned as a result of designing, operating, and monitoring the Visitor Center Complex for use in future projects, and

- investigate opportunities for improving the operating performance of the Visitor Center Complex.

The postoccupancy evaluation measured and assessed the energy performance of the Visitor Center Complex from September 1, 2000 to June 1, 2003. This evaluation was crucial to achieving and verifying the low-energy design goals. This report presents results from that multiyear performance monitoring. The new transportation system was not studied as part of the building evaluation.

\footnotetext{
${ }^{1}$ National Park Service Web site for Zion National Park: http://www.nps.gov/zion/home.htm
} 


\subsection{Energy Use in Commercial Buildings in the United States}

In 2001, commercial buildings accounted for approximately $18 \%$ of total primary energy consumption in the United States. The total for all buildings is over one-third of primary energy consumption and $70 \%$ of primary $^{2}$ electricity consumption. Energy use in buildings produces $35 \%$ of U.S. and $9 \%$ of global carbon dioxide $\left(\mathrm{CO}_{2}\right)$ emissions. Electricity consumption in the commercial building sector has doubled during the last 18 years, and if current growth rates continue, it is expected to increase by another $25 \%$ by 2030 (EIA 2002). Reducing site energy consumption in commercial buildings through energy-efficient and renewable building technologies would significantly reduce primary energy consumption in the United States (DOE 2003). Because utility bills are based on site energy consumption, site energy is also a concern for the building owner or those paying the bills.

\subsection{Building Evaluation Scope}

NREL selected the ZNP Visitor Center Complex as a technical case study to further the laboratory's research of high-performance buildings. NREL, in collaboration with the staff at ZNP, monitored, evaluated, and documented the energy performance of the Visitor Center Complex and how the design process helped to achieve this performance. The evaluation covers the period from September 1, 2000 to June 1, 2003. The evaluation presented in this report focuses on the integration and interactions of the high-performance building technologies in a whole-building environment, with additional analysis of the photovoltaic, cooling, and daylighting systems.

\subsection{High-Performance Buildings Research Objectives}

NREL conducts research for the U.S. Department of Energy's (DOE) High-Performance Buildings initiative (HPBi). HPBi evaluates commercial buildings from a whole-building perspective to understand the impact of integrated design issues on energy use and costs in commercial buildings while improving other attributes of the building such as occupant satisfaction. Documenting the high performance of research-level buildings provides evidence that energy-efficient buildings work, helping transform the marketplace. In addition, documenting common threads and analysis methodologies provides direct assistance to industry. HPBi's research objectives are to:

- develop processes for high-performance building design, construction, and operation,

- provide the tools needed to replicate the processes,

- research new technologies for high-performance buildings,

- develop standardized metrics and procedures for measuring building energy performance, and

- measure and document building performance in high-profile examples.

\subsection{Report Organization}

Section 2 provides background information on commercial building energy performance. Section 3 describes the low-energy design process in general terms along with how that process was applied to the Visitor Center Complex project. Section 4 describes the building as constructed. Section 5 discusses methods for determining overall performance of the Visitor Center Complex as it was built and operated. Section 6 provides in-depth analysis of major building systems. Section 7 lists our recommendations from lessons learned throughout the project and Section 8 summarizes conclusions from the evaluation of the Visitor Center Complex.

\footnotetext{
${ }^{2}$ Primary electricity is the site electricity plus the distribution and conversion losses at the utility plant.
} 


\section{Background}

NREL selected the Zion National Park Visitor Center Complex as a research effort because the design team and building owner were committed to aggressive energy saving goals. The NPS also agreed to post-occupancy energy monitoring. Although not used directly for comparison purposes, an analysis of commercial buildings in the United States was performed.

In 2002, the Energy Information Administration (EIA) conducted the Commercial Buildings Energy Consumption Survey (CBECS), a national survey that collected information about thousands of commercial buildings in the United States including energy consumption during 1999. Data surveyed includes building physical and operating characteristics, energy consumption, and energy expenditures for all types of commercial buildings across U.S. climatic regions. The EIA defines energy intensity as site energy consumption per square foot of total floor space (EIA 2002). The Visitor Center Complex is a combination of office, retail, and service and does not directly fit into any specific category of the CBECS database. See Figure 2-1 for a comparison of energy use and energy costs for a variety of building types in the Western United States.

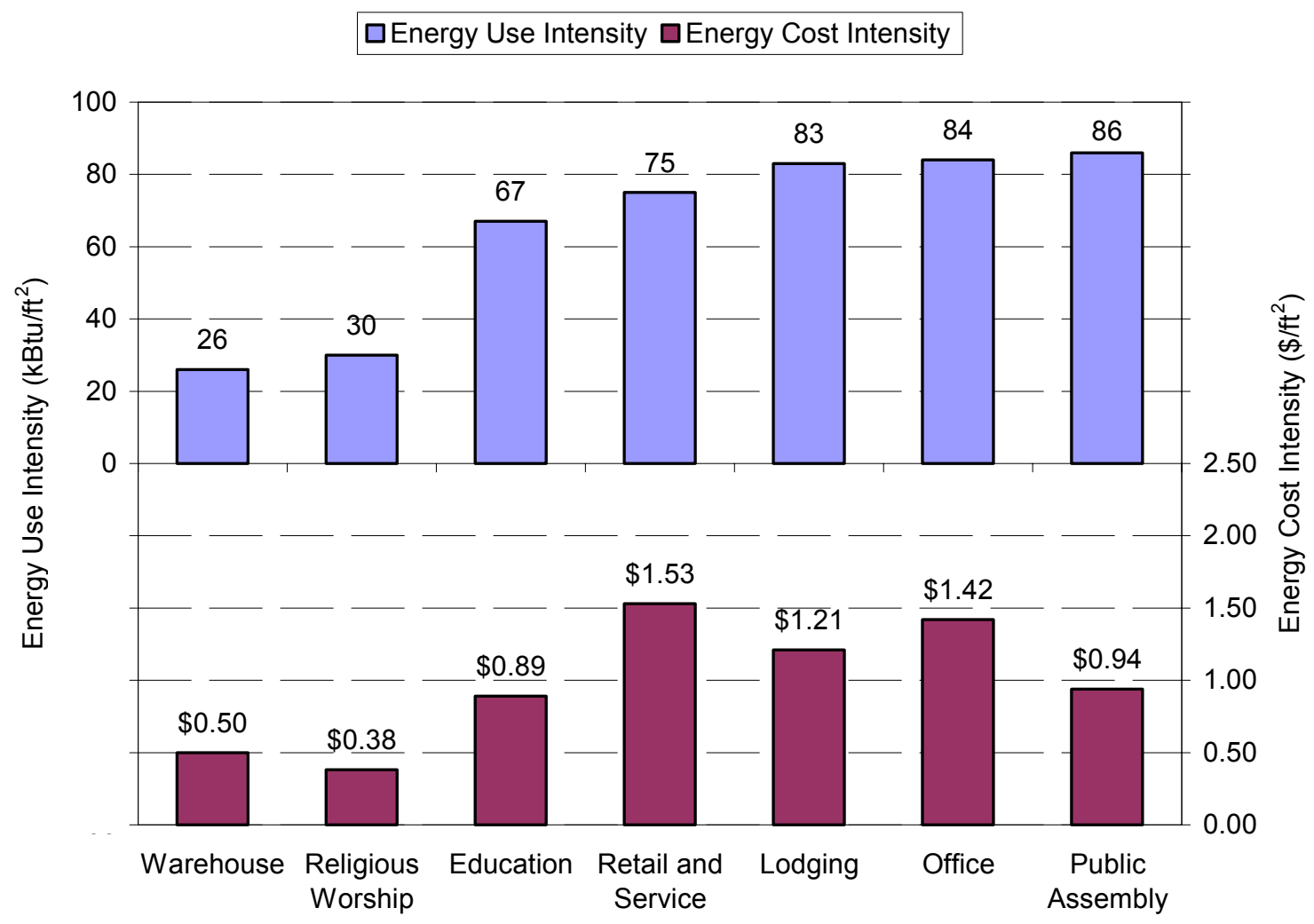

Figure 2-1 1999 Energy Use and Costs by Building Type for Western U.S. (EIA 2002)

ENERGY STAR ${ }^{\circledR}$ performance ratings for commercial buildings can also be used as a basis for building energy use comparison. An EPA study attempted to recognize the most energy-efficient and costeffective commercial buildings in the country (Hicks 2000). The average annual energy use for buildings in the study was $56.4 \mathrm{kBtu} / \mathrm{ft}^{2} \cdot \mathrm{yr}\left(641 \mathrm{MJ} / \mathrm{m}^{2} \cdot \mathrm{yr}\right)$. This average represents buildings of all sizes and various sectors. A comparison of CBECS and ENERGY STAR are shown in Table 2-1. These structures tend to be larger office buildings with a total area greater than $50,000 \mathrm{ft}^{2}\left(4645 \mathrm{~m}^{2}\right)$. 
Table 2-1 Energy and Cost Intensities by EPA Study

\begin{tabular}{|l|c|c|c|}
\hline \multicolumn{1}{|c|}{ EPA Study } & $\begin{array}{c}\text { Site Energy } \\
\text { Intensity } \\
\mathrm{kBtu} / \mathrm{ft}^{2} \cdot \mathrm{yr} \\
\left(\mathrm{MJ} / \mathrm{m}^{2} \cdot \mathrm{yr}\right)\end{array}$ & $\begin{array}{c}\text { Source Energy } \\
\text { Intensity } \\
\mathrm{kBtu} / \mathrm{ft}^{2} \cdot \mathrm{yr} \\
\left(\mathrm{MJ} / \mathrm{m}^{2} \cdot \mathrm{yr}\right)\end{array}$ & $\begin{array}{c}\text { Energy Cost } \\
\text { Intensity } \\
\$ / \mathrm{ft}^{2} \cdot \mathrm{yr} \\
\left(\$ / \mathrm{m}^{2} \cdot \mathrm{yr}\right)\end{array}$ \\
\hline ENERG STAR Average & $56.4(641)$ & $150.9(1,714)$ & $1.12(12.06)$ \\
\hline CBECS Adjusted Average & $101.1(1,148)$ & $261.8(2,973)$ & $1.62(17.44)$ \\
\hline CBECS Adjusted Top 25\% & $48.2(547)$ & $113.9(1,294)$ & $0.81(8.72)$ \\
\hline CBECS Adjusted Bottom 25\% & $217.0(2,464)$ & $511.0(5,803)$ & $2.80(30.14)$ \\
\hline
\end{tabular}

The top CBECS and ENERGY STAR buildings are examples of energy-efficient and cost-effective commercial structures. Documenting the performance of other commercial buildings provides a reference for comparing these high-performance facilities. A high-performance building is one that is designed, built, and operated to use less than one-half the energy of typical buildings.

Many buildings that are designed to be energy efficient do not actually meet these targets. For example, a recently completed educational building designed to be energy efficient did not initially meet the energy design expectations (Pless 2004). Postoccupancy evaluation of the building operation identified how this low-energy building could operate at high-performance levels. 


\section{Design Process}

This section outlines how we used the low-energy design process (located in Appendix A) to integrate energy efficiency into the Visitor Center Complex. It describes the steps of the design process starting from the beginning, which is setting energy goals, and continues through brainstorming new design solutions after initial energy simulation of the base-case building model.

\subsection{Rationale for Design}

The initial motivation for the design of the new Visitor Center Complex was to resolve transportation problems within the park. During the summer, more than 3,000 visitors per hour visit ZNP, but only 400 parking spaces were available in the canyon. As a result, problems such as traffic congestion, noise, and visitor safety concerns were increasing. In addition, the automobiles caused substantial damage to the canyon's flora and fauna. Figure 3-1 shows an example of the parking problem. (NPS 1995).

In addition to the new transportation system, new visitor facilities were needed. The old facility had limited space for interpretive displays to describe ZNP features and wildlife. Furthermore, the restrooms were unable to handle the increased guest load and the layout of the building was not effective in serving large crowds. Another issue that influenced the Visitor Center Complex's design was the NPS desire to have any new buildings complement the surrounding natural environment to preserve the tranquility of the area.

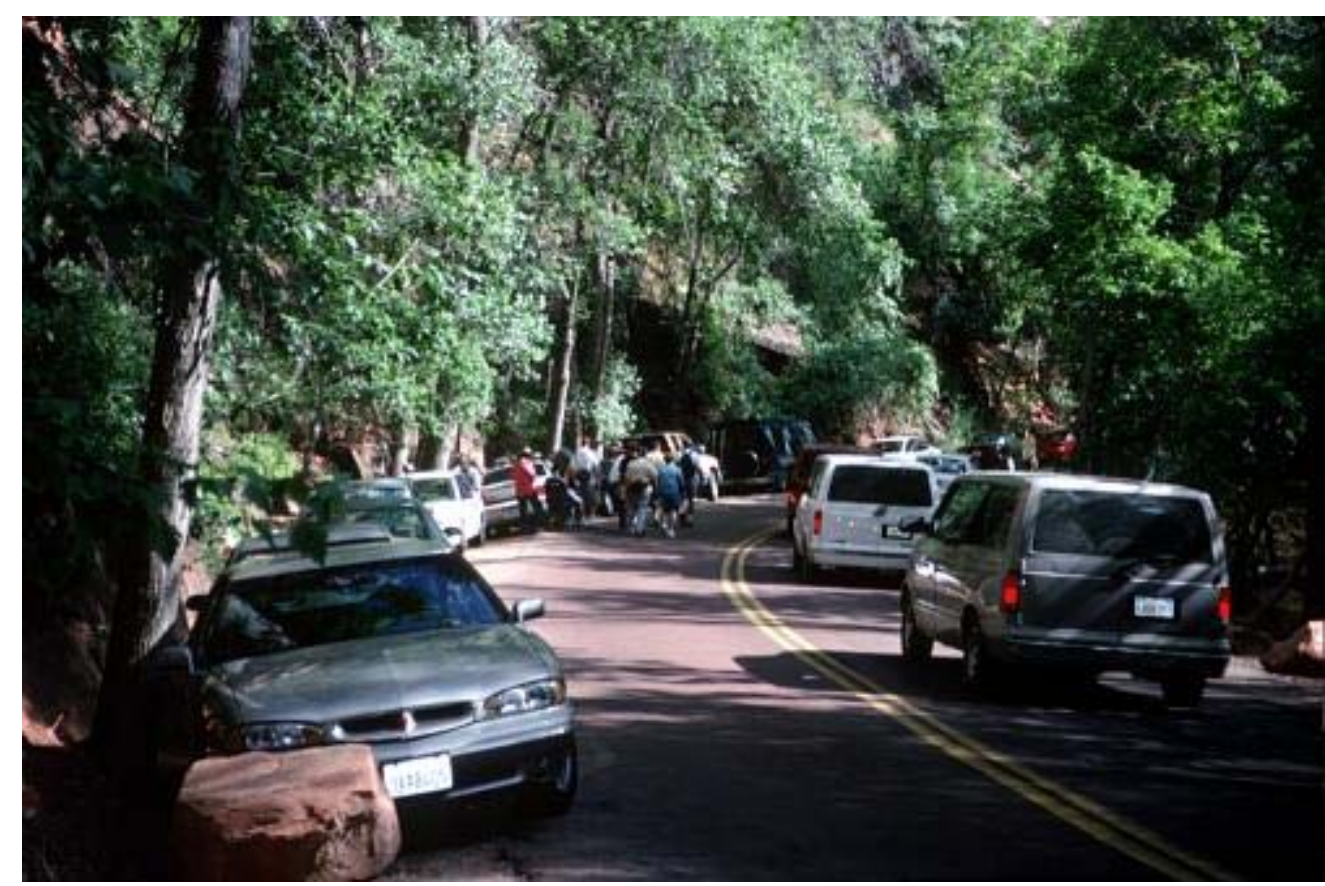

Figure 3-1 Summer traffic congestion, traffic back-ups, and parking issues

\subsection{Applying the Design Process}

The Visitor Center Complex project followed the low-energy design process outlined in Appendix A. This section describes how the low-energy design process was applied for this project. Note that several building concepts were created during the application of this design process, see Figure 3-2. The original conceptual design was an 18,000- $\mathrm{ft}^{2}$ building with displays and exhibits located indoors. After conceptual 
design, the displays and exhibits were moved outdoors, which enabled us to design a much smaller building. In addition, the building was split into two buildings, (1) a Visitor Center [7,600 $\left.\mathrm{ft}^{2}\left(710 \mathrm{~m}^{2}\right)\right]$ and (2) a Comfort Station [1,560 $\left.\mathrm{ft}^{2}\left(145 \mathrm{~m}^{2}\right)\right]$, as shown in Figure 3-2 as the proposed design. The proposed base case for the proposed design only modeled the Visitor Center. During design, the location of the building on the site changed, requiring a building redesign. The new design (the as-built design) consisted of a Visitor Center $\left[8,800 \mathrm{ft}^{2}\left(818 \mathrm{~m}^{2}\right)\right]$, Comfort Station $\left[2,756 \mathrm{ft}^{2}\left(256 \mathrm{~m}^{2}\right)\right]$, and a Fee Station $\left[170 \mathrm{ft}^{2}\left(15.8 \mathrm{~m}^{2}\right)\right]$. Details of applying the 10-step low-energy design process are discussed below.

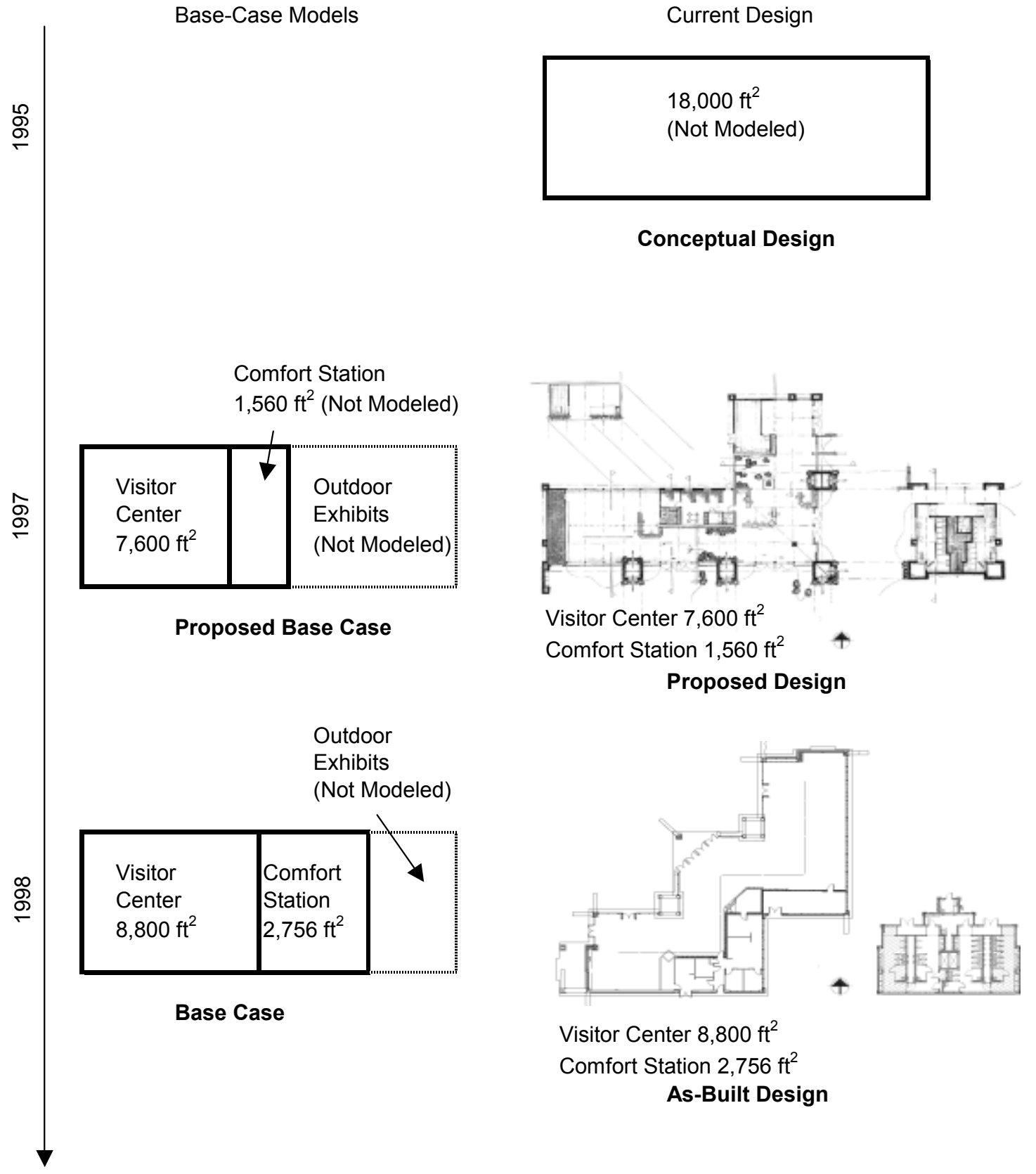

Figure 3-2 Flowchart of building designs 


\subsubsection{Step 1: Predesign}

Low-energy architecture requires the setting of clear, measurable energy performance goals and tracking progress toward that goal. Goals provide an energy saving target to achieve and a value to compare energy performance. For this project, an energy-cost saving goal of $70 \%$ was set at the beginning of the design process and used as an energy saving target throughout the process.

Another important part of predesign is to evaluate the climate in which the building is located. To help the NPS determine the best design for their new building, a series of design charrettes were held at ZNP. Participating were ZNP staff, NREL building researchers, and NPS engineers and architects. The attendees of the charrette spent several days camping in ZNP to gain a better understanding of the environmental conditions of the canyon, which heavily influenced the design process. During the first part of the design charrette, NREL and NPS staff observed natural cooling within the canyon that could easily be adapted to the built environment. A temporary weather station recorded hourly integrated values of shielded air temperature, relative humidity, global horizontal solar radiation, wind speed, and wind direction. This data was used to quantify the observations of the design team. These were important observations for a region where daily high summer temperatures regularly exceed $100^{\circ} \mathrm{F}$ $\left(38^{\circ} \mathrm{C}\right)$, as shown in Figure 3-3.

It was apparent from the site visit that the local microclimate provided many ideas for the design concepts that could be used to provide comfort in and around the visitor center. The Virgin River canyon controlled many aspects of the microclimate. The narrow canyon walls, splashing water, and vegetation at the riverbanks provided shade and evaporatively cooled air in sharp relief to the aridness and extreme heat. In some places, seeps wetted the canyon walls, creating a cooling effect. In other places, the seeps nourished blooms of wet moss that behave much as the wetted media in a commercial evaporative cooler. The overall geometry of the canyon, which was deep and narrow up-river of the site and widened progressively in the down-river direction, created a diurnal chimney effect with up canyon winds from about noon to midnight and down canyon winds from midnight to noon. The lighting in the narrow parts of the canyon was diffuse with a pleasant contrast ratio and without the unpleasant impact of the direct sun. A winter visit was also informative with solar heating of exposed canyon mass surfaces often adequate to provide outside comfort during the day.

Thus were born many of the overall energy, lighting and human comfort architectural design concepts for the complex. These are summarized as follows:

- Create a shaded microclimate around the buildings in summer and solar exposure in winter with plantings of deciduous trees and overhead arbors.

- Provide irrigation throughout the space with small irrigation canals similar to the historic ones found in the canyon. Although not implemented in this project, it is possible to use porous patio materials to create an evaporatively cooled walking surface.

- Create passive evaporative downdraft cooltowers to cool the building without the need for blowers or vapor compression equipment.

- Use the diurnal winds to help drive a natural ventilation system and to boost the cooltower's air delivery with wind pressure.

- Control automated clerestory windows and the cooltowers with the building automation system to create an integrated, controllable natural cooling system.

- Specify the thermal and optical properties of glass; size and orient windows and shading devices to provide diffuse light with minimal solar load in summer, and light and solar heat in winter.

- Use massive building materials on the interior to modulate temperature swings and store solar heat in winter and cool night air in summer. 
- Construct noncirculating Trombe walls on the south face of the buildings for additional passive heating with a time delay into the late afternoon and evening hours.

- Allow enough south-oriented pitched roof surface to accommodate photovoltaic panels so that the building can operate effectively and comfortably despite frequent summer power outages.

In addition to borrowing elements from the natural cooling and heating taking place within $\mathrm{ZNP}$, the design team also evaluated the original program requirements for building size to discover if further energy saving measures could be incorporated into the design. Because $90 \%$ of the total annual visitors are in ZNP during the hot and dry summer, the design team determined that many of the exhibits could be moved to permanent areas outside the building. By providing shading and water for visitors and creating outdoor exhibit areas, the building became smaller, less expensive, and thus, it would require less energy to operate. Finally, visitors would have access to the displays when the Visitor Center is closed. Overall, the building footprint was reduced from $18,000 \mathrm{ft}^{2}\left(1,670 \mathrm{~m}^{2}\right)$ to $11,726 \mathrm{ft}^{2}\left(1090 \mathrm{~m}^{2}\right)$.

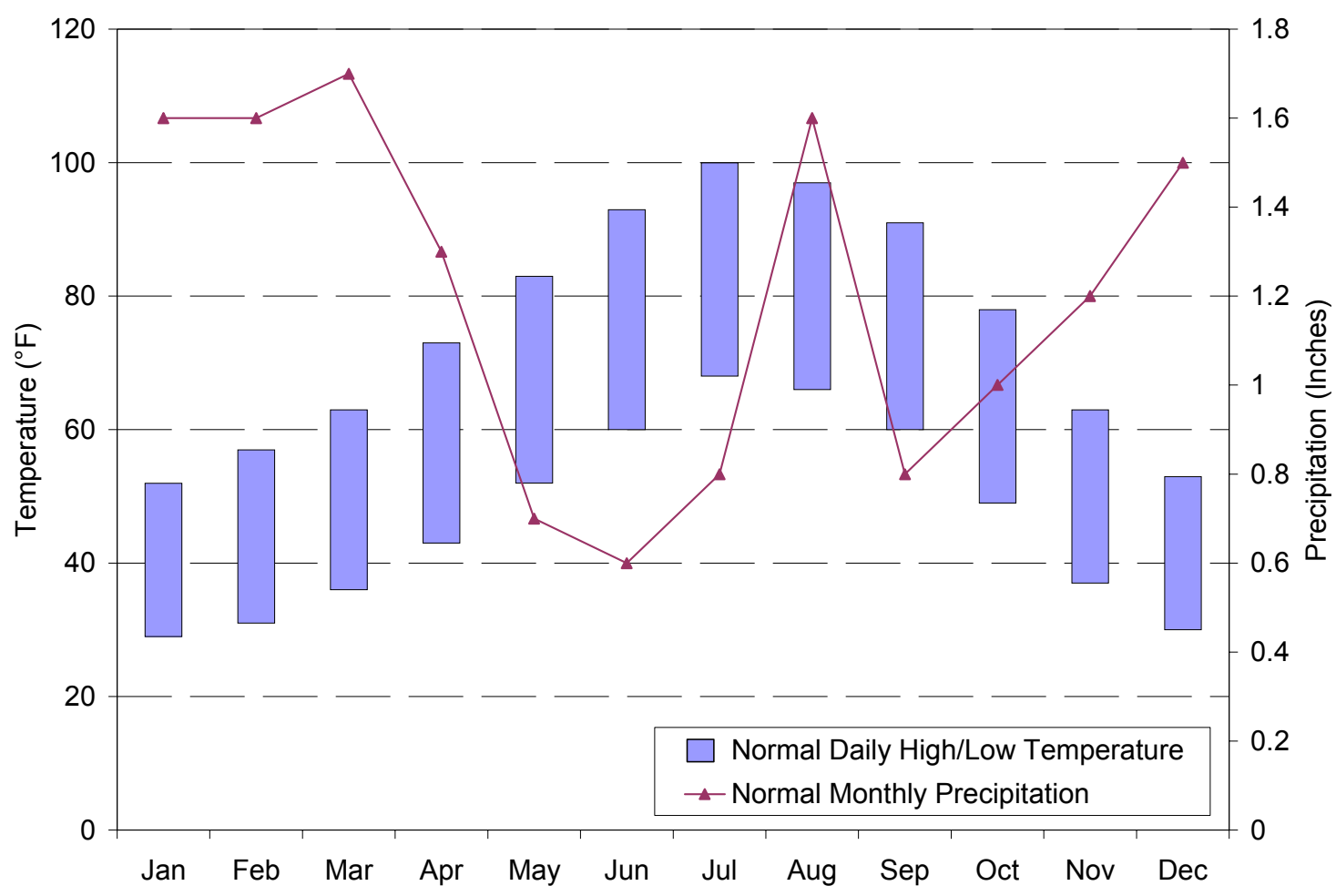

Figure 3-3 Typical monthly average daily weather for ZNP

\subsubsection{Step 2: Create a base-case building model}

At this stage of the project, a base-case model was created for the Visitor Center using DOE-2 simulation software (Winkelmann et. al. 1993). The software was used to help design elements of the building related to energy efficiency. This model reflected the floor area equal to the proposed smaller footprint for the Visitor Center [7,600 $\left.\mathrm{ft}^{2}\left(706 \mathrm{~m}^{2}\right)\right]$.

The theoretical base-case building was developed to provide a starting point for the analysis as well as a metric against which to measure the energy savings success of the project. It also set the groundwork for guiding the design process using energy simulation tools. Most of the analysis took place early in the design process in parallel with the programming and goal setting exercises. The initial base case was modeled as a square, single-floor building, as shown in Figure 3-4. The model was solar neutral (equal 
glazing areas on all orientations) and met the minimum requirements of the Federal Energy Code 10 CFR 435 (DOE 1995) (based on ANSI/ASHRAE/IESNA Standard 90.1-1989 (ASHRAE 1989) with additional lighting requirements). Based on visitor data from the NPS, the maximum number of occupants was assumed to be 100, and occupancy schedules were based on typical operation hours of the existing facility. Outside ventilation air in the base-case model was set at a constant rate during occupied hours equal to $15 \mathrm{cfm}$ per person. Depending on the zone, lighting levels were set to retail, office, and exhibit lighting levels with no reduction for daylighting. Table 3-1 summarizes building characteristics used in the base-case model.

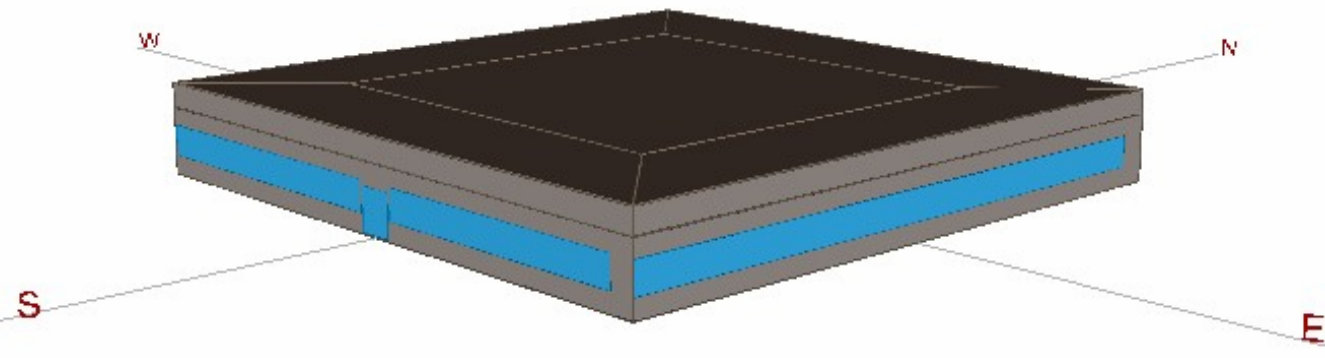

Figure 3-4 Simulated 7,600-ft ${ }^{2}\left(706-\mathrm{m}^{2}\right)$ base-case model

Table 3-1 Base-Case Model Characteristics

\begin{tabular}{|l|c|}
\hline \multicolumn{1}{|c|}{ Item } & Proposed Base Case \\
\hline Size, $\mathrm{ft}^{2}\left(\mathrm{~m}^{2}\right)$ & $7,600(706)$ \\
\hline Heating System & Propane \\
\hline Cooling System & $\begin{array}{c}\text { Packaged Single-Zone } \\
\text { Air Conditioner }\end{array}$ \\
\hline Hot-Water System & Propane \\
\hline Wall R-Value, $\mathrm{ft}^{2} \cdot{ }^{\circ} \mathrm{F} \cdot \mathrm{hr} / \mathrm{Btu}\left(\mathrm{m}^{2} \cdot \mathrm{K} / \mathrm{W}\right)$ & $13.9(2.45)$ \\
\hline Window R-Value, $\mathrm{ft}^{2} \cdot{ }^{\circ} \mathrm{F} \cdot \mathrm{hr} / \mathrm{Btu}\left(\mathrm{m}^{2} \cdot \mathrm{K} / \mathrm{W}\right)$ & $0.58(0.10)$ \\
\hline Window-to-Wall Area & $30 \%$ \\
\hline $\begin{array}{l}\text { Floor Perimeter Insulation }(4 \mathrm{ft} \text { of vertical } \\
\text { foundation insulation) } \mathrm{R}-\mathrm{Value}, \\
\mathrm{ft}^{2} \cdot{ }^{\circ} \mathrm{F} \cdot \mathrm{hr} / \text { Btu }\left(\mathrm{m}^{2} \cdot \mathrm{K} / \mathrm{W}\right)\end{array}$ & $4(0.7)$ \\
\hline Roof R-Value, $\mathrm{ft}^{2} \cdot{ }^{\circ} \mathrm{F} \cdot \mathrm{hr} / \mathrm{Btu}\left(\mathrm{m}^{2} \cdot \mathrm{K} / \mathrm{W}\right)$ & $22.7(4.00)$ \\
\hline Infiltration $(\mathrm{ACH})$ & 1 \\
\hline Equipment load, W/ft ${ }^{2}\left(\mathrm{~W} / \mathrm{m}^{2}\right)$ & $0.75(8.1)$ \\
\hline Daylighting & No \\
\hline Overhangs & No \\
\hline Demand Limiting Controls & No \\
\hline Lighting Power Density, $\mathrm{W} / \mathrm{ft}^{2}\left(\mathrm{~W} / \mathrm{m}^{2}\right)$ & $1.4(15)$ \\
\hline Office Space & $2.2(24)$ \\
\hline Retail and Display Space & Not Modeled \\
\hline Restrooms & Not Modeled \\
\hline Outdoor and Parking Lot $(\mathrm{W})$ & \\
\hline
\end{tabular}


The heating and cooling equipment modeled in the initial base-case model represent typical HVAC equipment complying with the applicable federal energy code. The heating system was modeled as a propane furnace with $80 \%$ annual fuel utilization efficiency. The cooling system was modeled as a packaged single-zone air conditioner with a coefficient of performance (COP) of 3.0. Many of these base-case characteristics were based on typical park practice information provided by NPS staff. Local electric utility rates and propane costs were used in the base-case model to calculate energy costs of the proposed design and initial base case. Natural gas is not available at the site.

Conventional retail building construction characteristics vary, so it is difficult to justify base-case model characteristics that do not conform to a universally accepted standard set of criteria. ASHRAE Standard 90.1-1989 is a consensus-based standard that outlines the minimum building energy design requirements. The Federal Energy Code (10 CFR 435) adopted this industry standard in its entirety along with stricter lighting requirements. Many municipalities do not require or strictly enforce Standard 90.1 or 10 CFR 435 requirements. Therefore, a building designed to meet 10 CFR 435 is often a better building than conventional construction in that year. This also provides a standard metric for comparing percent savings among buildings. The base-case building described in this paper is for energy comparison only.

\subsubsection{Step 3: Parametric Analysis}

Using the base-case building simulations, we conducted an elimination parametric analysis to evaluate the effects of specific elements of the Visitor Center. See Table 3-2 for a description of the parametric simulations. For example, the U-value of the wall, floor, roof, and windows were individually eliminated (set to near-zero) to simulate zero heat transfer across these components. As shown in Figure 3-5, the building energy requirements resulting from these simulations showed that daylighting, shading, natural ventilation, evaporative cooling, and passive solar heating reduced total building energy requirements the most.

Table 3-2 Parametric Analysis Description

\begin{tabular}{|l|l|}
\hline Parametric Alternative & \multicolumn{1}{|c|}{ Description } \\
\hline Base Case & Code minimum as defined in Step 2 above \\
\hline Daylighting On & Daylighting enabled in simulation \\
\hline No Internal Gains & Remove all receptacles, lighting, and occupants \\
\hline No Window Conduction & No conduction across windows (R-99) \\
\hline No Wall Conduction & No conduction through walls (R-99) \\
\hline No Roof Conduction & No conduction through roof (R-99) \\
\hline No Floor Conduction & No conduction through floor slabs (R-99) \\
\hline No Infiltration & No uncontrolled outside air \\
\hline No Sun (SHGC $=\mathbf{0})$ & No solar heat gain through windows \\
\hline $\mathbf{5 x}$ Internal Mass & Five times more thermal capacitance \\
\hline $\mathbf{2 5 x}$ Internal Mass & Twenty five times more thermal capacitance \\
\hline
\end{tabular}




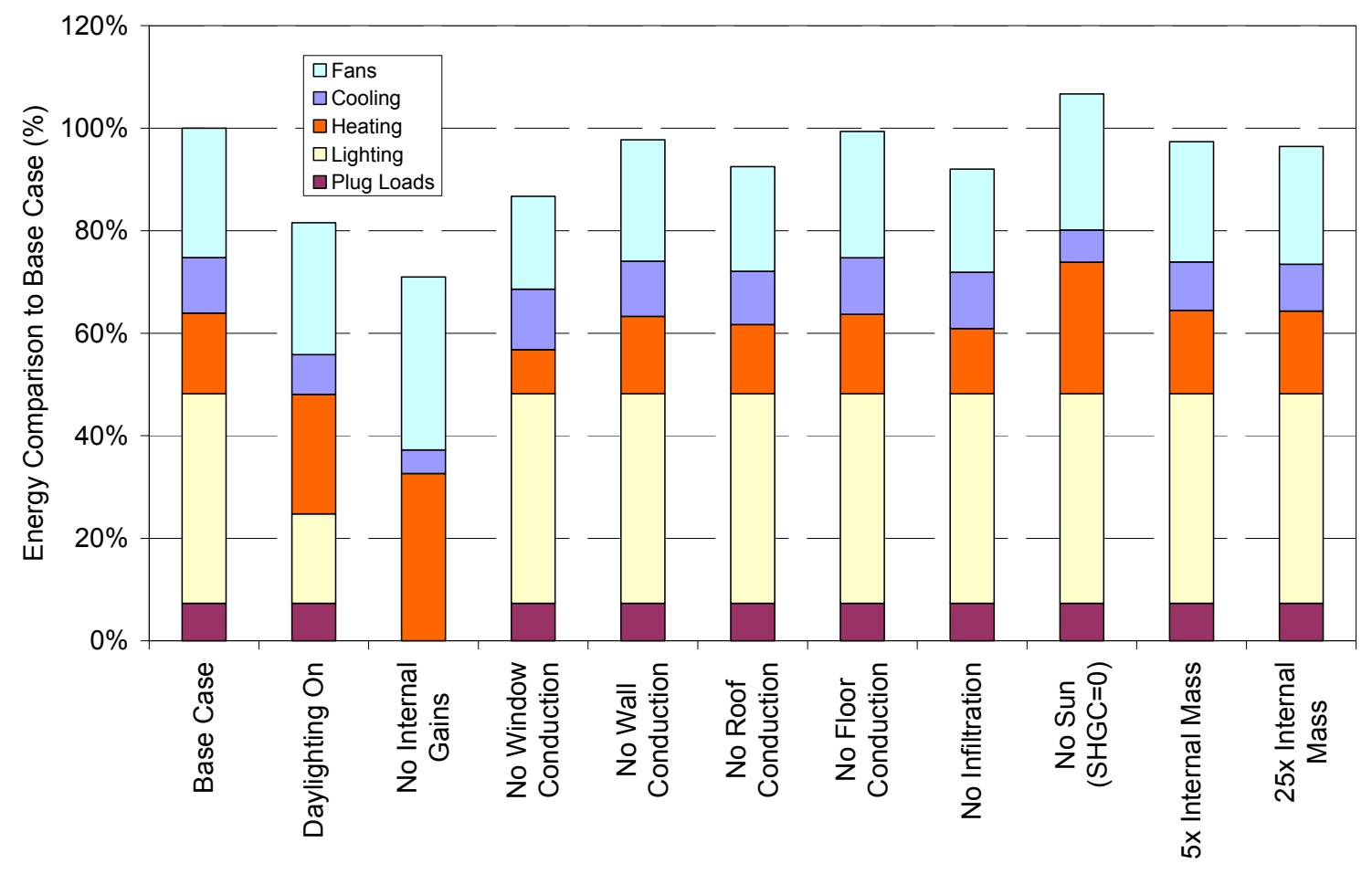

Figure 3-5 Parametric analysis results

\subsubsection{Step 4: Design Solutions to Reduce Energy Consumption}

The parametric analysis showed that cooling is a significant part of the building's total energy loads. Eliminating solar gains ("no sun" parametric) produced the greatest reduction in the cooling load. This observation helped the design team focus on developing strategies that reduce solar gain. Reducing large internal heat gains produced from lighting also reduced the cooling loads. As a result, the design team incorporated daylighting strategies and used a daylighting design that avoids excessive solar gains during the cooling season. The daylighting design allowed fewer and more efficient lights to be installed, which decreased the overall internal loads.

The building envelope design minimizes summer solar gains with window overhangs and reduces electric lighting loads with large south-facing windows that allow more natural light to enter the building (see Figure 3-6). However, the building envelope design did not offset the entire cooling load. Next, natural ventilation cooling was integrated with the daylighting design - automatic window actuators were added to the clerestory windows. For more information on the natural ventilation system, see Section 4.4. The remaining cooling loads were met by the evaporative cooltower system discussed below. 


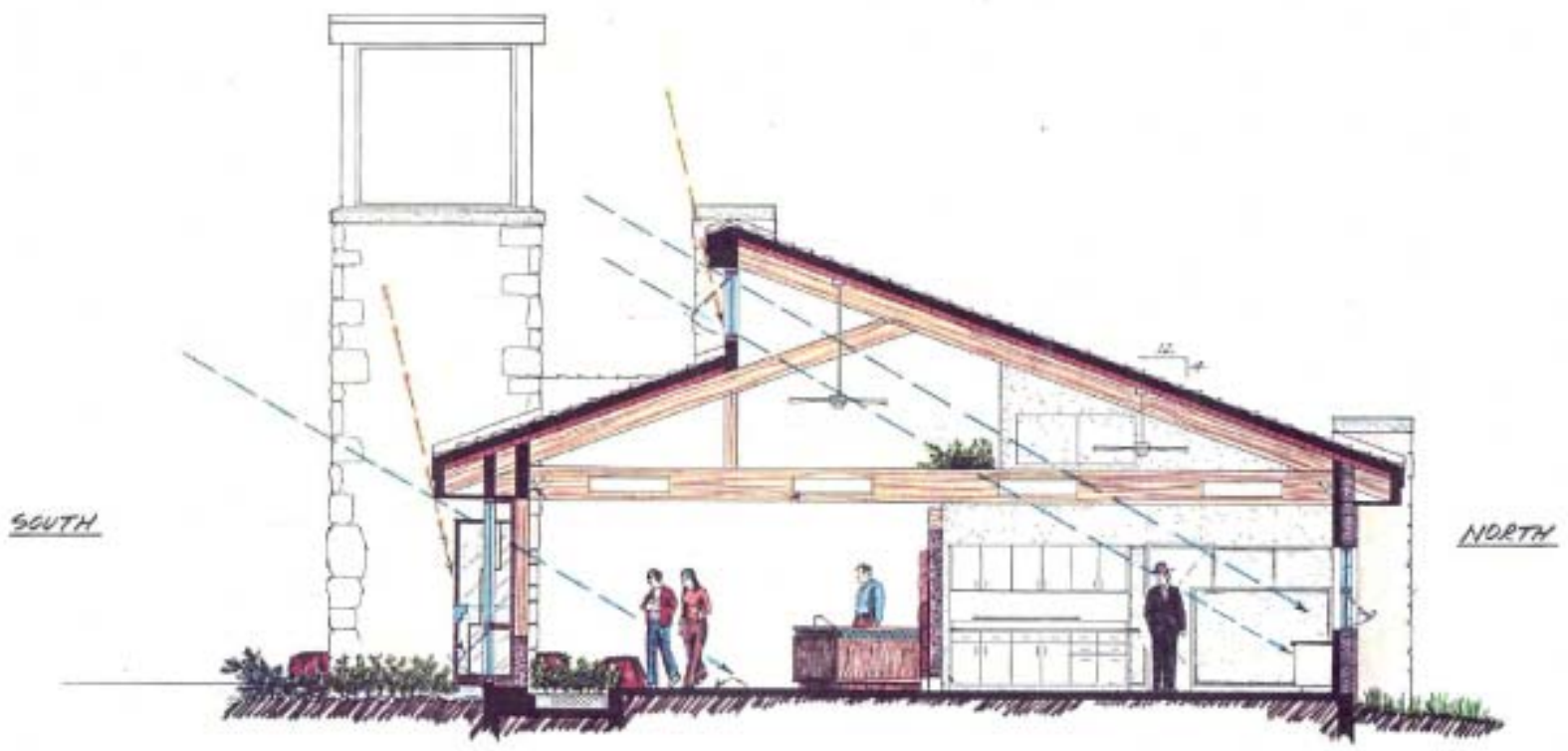

Figure 3-6 Diagram of energy design solutions for the Visitor Center Complex

The parametric analysis showed that by eliminating solar gains ("no sun" parametric), building heating loads would increase. Winter solar gains help reduce heating loads. The resulting design solution incorporated direct solar gain through the clerestory windows and a Trombe wall along the entire south face of the building; see Section 4.4.1 for more details on the Trombe Wall. A properly sized overhang allows the low winter sun to heat the Trombe wall, while shading it in the summer when the sun is higher in the sky, thereby decreasing the cooling load. We designed the overhangs for south-facing windows to allow direct solar gain in the winter and eliminate summer solar gains. To maximize solar gains through south-facing windows, we specified a high SHGC glazing. Because it is difficult to shade west-facing windows, we specified all west-facing glass with low SHGCs. Finally, the parametric analysis showed that by eliminating window conduction, we could minimize the heating load. This leads to the conclusion that we should minimize glass area except for daylighting and passive heating purposes. We determined window properties by running simulations with different predefined window constructions. Because window SHGC and U-Value are interconnected, we selected windows that matched closest to the simulated specifications.

\subsubsection{Step 5: Simulate Performance of Design Solutions}

We used computer simulations to quantitatively evaluate the effectiveness of the various strategies for reducing loads and using natural heat flows available in the canyon. We first carefully studied those strategies that affected building architecture in preparation for the next design process step.

Based on our analysis, we had the following recommendations:

- Minimize east and west glass. West glass should have a low SHGC. North glass should be used for daylighting only.

- Use north, west, and east glass with lowest possible U-values.

- Use Trombe walls to provide passive solar heat without adding glare to the space. (Trombe walls delay heat gain into the buildings to the early evening when it can be best used.)

- Use extensive daylighting to reduce lighting energy and reduce internal energy loads from the lights. 
- Use reasonable levels of insulation, meeting or exceeding the requirements of 10 CFR 435.

- Use overhangs to block summer sun from south-facing windows.

- Use natural ventilation together with evaporative cooling to meet the remaining cooling loads.

\subsubsection{Step 6: Conceptual Design}

During this stage of design, energy-efficient strategies were incorporated into the architectural design. For example, the original building envelope concept included the use of tall architectural elements to unify the building with the surrounding canyon walls. The team evaluated the use of downdraft cooltowers for the cooling system as one means of introducing a tall element into the architectural scheme. Cooltowers, while similar to direct evaporative coolers, do not use fans. Original plans called for five cooltowers located at the building corners. This not only met the architectural needs of the building, but also provided benefits for energy performance.

Further cooling was achieved by strategically placing operable windows to promote natural ventilation and passively move cool air through the space.

Through careful design of shading devices to minimize the solar gains, all cooling loads could be met with natural ventilation and the cooltowers. The only mechanical input to the cooling system is a pump used to circulate water through the evaporative media. The cooling system meets all summer ventilation requirements as well. During the winter, ventilation requirements are lower because of fewer visitors and can be met by infiltration through the building envelope as well as people entering and leaving the building.

During the winter, a Trombe wall provides most of the building heating. As with the cooling system design, simulations were used to optimize the envelope for winter performance. After the envelope was designed, the remaining heating, cooling, and lighting loads were studied and a small heating load remained. In the initial proposed design, the building was heated using propane. The initial concept was to use a propane fireplace that would serve as an architectural amenity as well as the heating system for the building.

At this point in the process, the design team investigated the potential impact of incorporating a photovoltaic (PV) system into the roof for electrical power. The design team provided the option to use $\mathrm{PV}$ in the future by designing a south-facing roof that was sloped to maximize the production of electricity. In addition, conduit to the roof and mounting brackets were added to the base building plan. Although not quantified, NPS personnel were concerned about the poor power reliability at the park. A UPS (uninterruptible power supply) was included in the original plan for the building electrical system. By specifying an inverter for this system that could handle the direct current input from a PV system, the UPS requested by the program could be PV powered. The UPS batteries were designed to deliver 2 hours of power without any PV. Using $3.6 \mathrm{~kW}$ of PV allowed the system to operate as long as there is sun. Space for an additional $3.6 \mathrm{~kW}$ of PV was allocated on the roof. This system was designed to be directly grid-tied.

Overall, observations from Step 1 of the design process helped clarify understanding of the natural environment in which the building would be located and prompted a careful analysis of the programmatic needs of the building. Daylighting, natural ventilation, evaporative cooling, minimizing summer solar gains with building shape and envelope features, massive building materials to stabilize indoor temperatures, passive solar heating, and siting with relation to mature trees and newly constructed outdoor shade structures were all part of the integrated building design. A roof-mounted PV array further reduces the building's environmental impact. The resulting proposed design floor plan and southern elevation are shown in Figure 3-7 and Figure 3-8. 




SOUTH ELEVATION

Figure 3-7 Initial proposed design of the Visitor Center

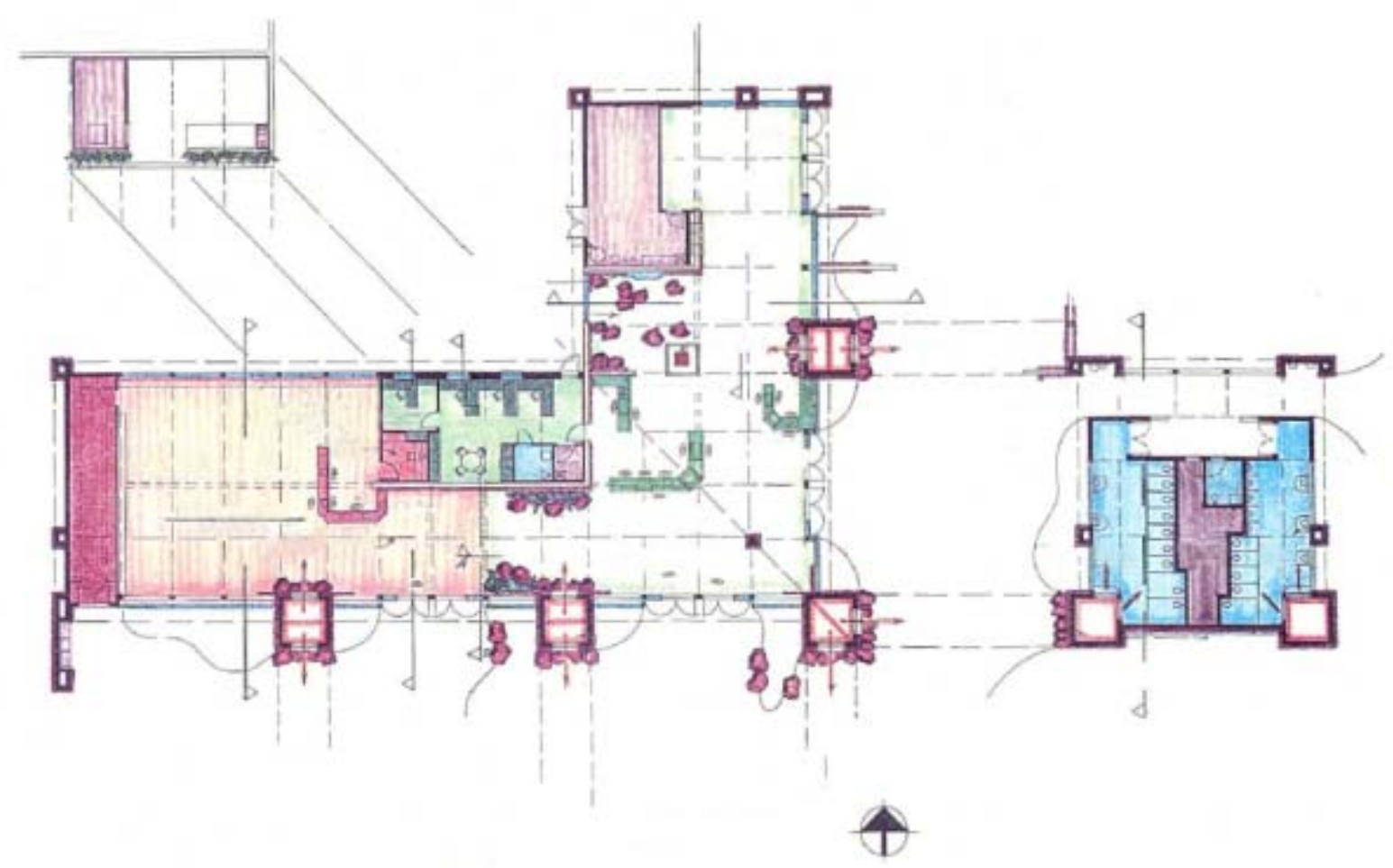

Figure 3-8 Conceptual design floor plan for Visitor Center and Comfort Station

(Step 6)

Step 6 resulted in the following design decisions related to energy impacts:

- The south roof slope should accommodate a future PV system. The electrical system should accommodate PV to be used in conjunction with a UPS system. The primary purpose for the PV system was to meet minimum building operation requirements. Additionally, electricity would serve building electrical needs whenever utility power was available.

- Cooling loads would be handled by cooltowers. The building interior would be designed to accommodate this technology by using operable high windows, natural ventilation, and open spaces with good airflow between the spaces. 
- Because the cooltowers use little energy, use them to cool the building as well as some outdoor locations as well. Encourage interpretation in these areas with exhibits and staff as "outdoor rooms," because people come to ZNP to spend time outside, not inside a building.

- Provide heating with a propane-powered fireplace to provide amenity and eliminate the central heating system. This eliminates the mechanical room.

The conceptual design for the Visitor Center is an example of how architectural features can enhance the energy performance as well as give the building a unique aesthetic style. In the Visitor Center, the building's window overhangs, clerestories, roofline, massive building materials, and other architectural features all contribute to the building's improved energy performance. Computer simulations allowed engineers to create an envelope that serves to function as most of the HVAC system.

\subsubsection{Step 7: Design Development}

The Visitor Center Complex comprised the main center (Visitor Center) and a separate restroom building (Comfort Station). The two buildings operated independently in terms of energy. The main interest for design development was to determine the savings of just the main Visitor Center. Therefore, we used an independently-zoned model to simulate only the main Visitor Center.

Heating in the proposed design was provided by using direct solar gain through south-facing windows as well as a Trombe wall. The design also included using clerestories to increase daylighting. The daylighting design was expected to fulfill most of the daytime lighting requirements.

The remaining electrical demand was small. Therefore, the roof was designed to accommodate a 7.2-kW PV system that could offset approximately $30 \%$ of the annual electrical load. In addition, the PV system is capable of meeting all functional requirements of the building during a daytime power outage - the cash registers, security system, BAS, cooltower pumps, and other essential equipment. The daylighting design was expected to be sufficient to maintain operational lighting levels during a power outage.

At the end of design development, energy cost savings were approximately $80 \%$ as compared to the $7,600-\mathrm{ft}^{2}\left(706-\mathrm{m}^{2}\right)$ base case. This was based on proposed design simulation models of the 7,600- $\mathrm{ft}^{2}$ $\left(706-\mathrm{m}^{2}\right)$ Visitor Center (not including the Comfort Station). The energy cost savings are shown in Figure 3-9, with corresponding cost and site energy savings data shown in Table 3-3 and Table 3-4. These savings do not include savings from the PV system. The proposed design model is shown in Figure 3-10.
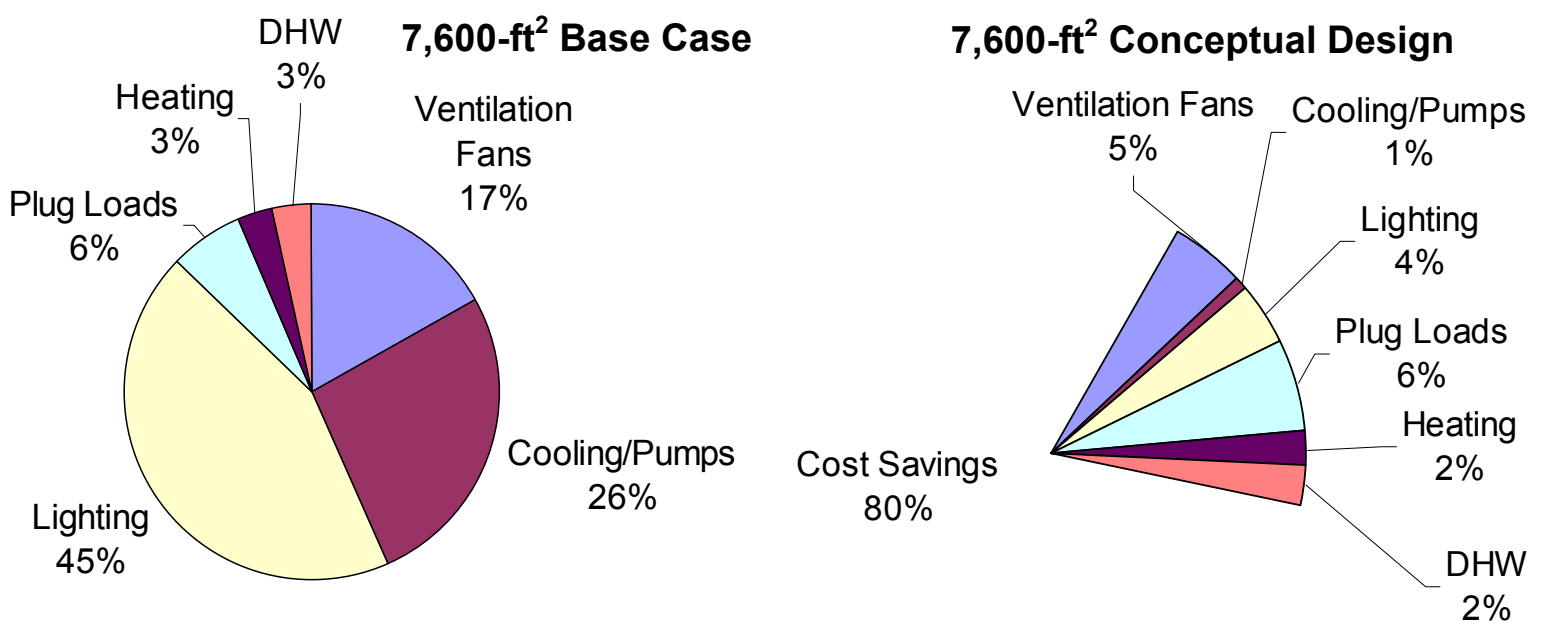

Figure 3-9 Simulated energy cost savings of base-case building compared to conceptual design (excluding the PV system) 
Table 3-3 Energy Use by End-Use

\begin{tabular}{|c|c|c|c|}
\hline End Use & $\begin{array}{l}\text { Base } \\
\text { Case } \\
(\mathrm{kWh}) \\
\end{array}$ & $\begin{array}{c}\text { Proposed } \\
\text { Design } \\
\text { (kWh) } \\
\end{array}$ & $\begin{array}{l}\text { Percent } \\
\text { Savings }\end{array}$ \\
\hline Heating $^{1}$ & 12,143 & 9,569 & $21.2 \%$ \\
\hline Cooling & 35,492 & 893 & $97.5 \%$ \\
\hline Ventilation Fans & 40,800 & 8,901 & $78.2 \%$ \\
\hline Domestic Hot Water $^{1}$ & 13,850 & 9,653 & $30.3 \%$ \\
\hline Lighting & 79,337 & 8,489 & $89.3 \%$ \\
\hline Plug Loads & 14,216 & 14,216 & $0.0 \%$ \\
\hline Total Energy & 195,838 & 51,721 & $73.6 \%$ \\
\hline
\end{tabular}

'27.98 kWh/Gal LPG [95,475 Btu/Gal LPG (7.39 kWh/liter)]

Table 3-4 Energy Cost Savings by End-Use

\begin{tabular}{|l|r|r|r|}
\hline \multicolumn{1}{|c|}{ End Use } & \multicolumn{1}{c|}{$\begin{array}{c}\text { Base } \\
\text { Case }\end{array}$} & $\begin{array}{c}\text { Proposed } \\
\text { Design }\end{array}$ & $\begin{array}{r}\text { Percent } \\
\text { Savings }\end{array}$ \\
\hline \hline Heating & $\$ 312$ & $\$ 246$ & $21.2 \%$ \\
\hline Cooling & $\$ 2,743$ & $\$ 97$ & $96.5 \%$ \\
\hline Ventilation Fans & $\$ 1,767$ & $\$ 479$ & $72.9 \%$ \\
\hline Domestic Hot Water & $\$ 357$ & $\$ 246$ & $31.1 \%$ \\
\hline Lighting & $\$ 4,567$ & $\$ 418$ & $90.9 \%$ \\
\hline Plug Loads & $\$ 662$ & $\$ 662$ & $0.0 \%$ \\
\hline Total Cost & $\$ 10,408$ & $\$ 2,148$ & $79.4 \%$ \\
\hline
\end{tabular}

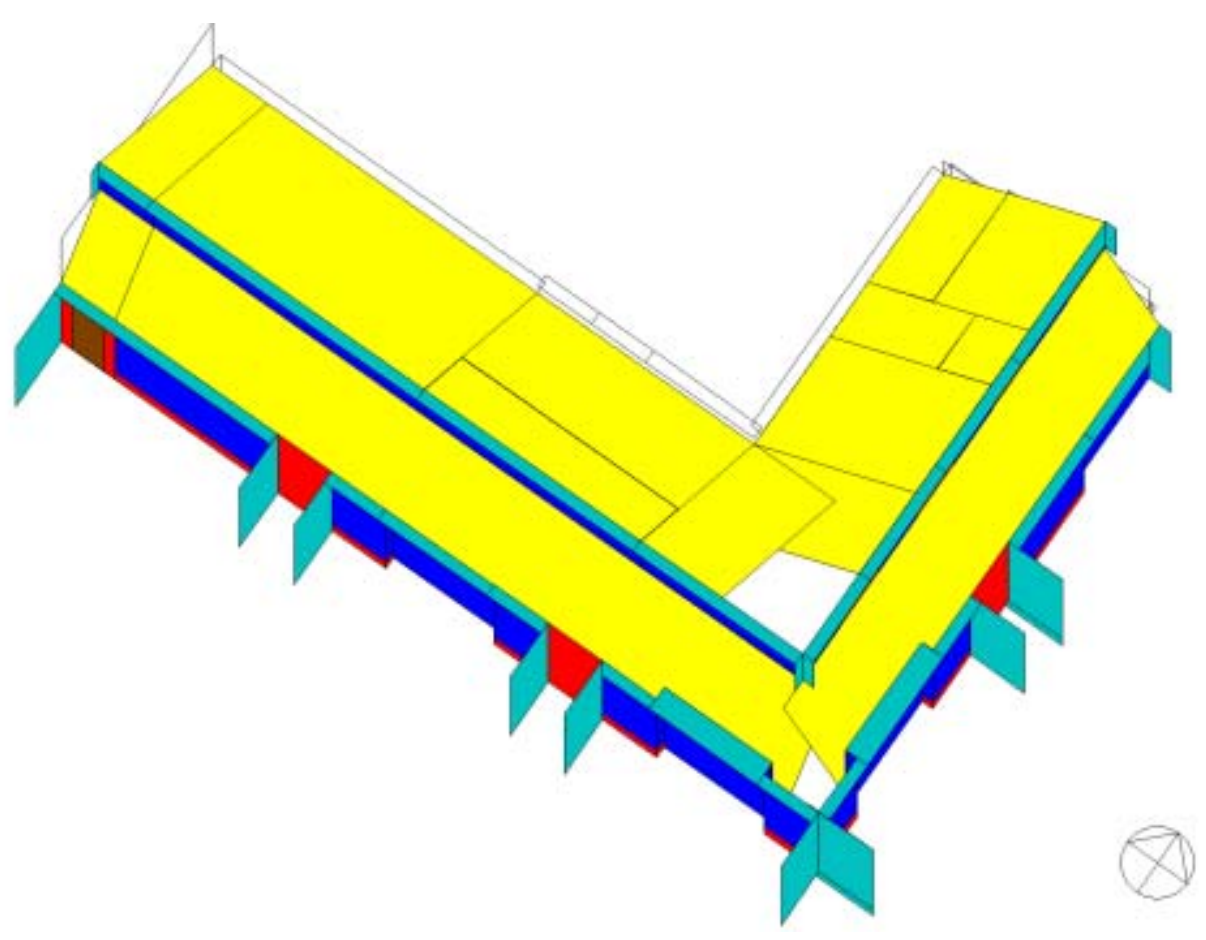

Figure 3-10 DOE-2 proposed design model 
The largest end use savings was the lighting. Design savings are based on using daylighting and lighting design. With the daylighting system, the lighting needs could be met with $0.75 \mathrm{~W} / \mathrm{ft}^{2}\left(8.1 \mathrm{~W} / \mathrm{m}^{2}\right)$.

Because of contrast ratios from inside to outside, lower light power densities can be used in daylit spaces. Typically, at night, less lighting is needed to make a space feel visually comfortable. In addition, most of the lights are expected to be off during the day. For a standard space of similar use, the code allows 2.2 $\mathrm{W} / \mathrm{ft}^{2}\left(24 \mathrm{~W} / \mathrm{m}^{2}\right)$. Reducing the lighting also reduced the cooling requirements.

The Comfort Station was designed in a similar fashion. Two cooltowers were specified in the proposed design for cooling the space. A Trombe wall was provided at the south facade for heating, while daylight from clerestories provided all the necessary daytime lighting.

\section{Project Redesign}

Part way through the design development process step, the building site changed. A new plan was developed to situate the structure on the east side of the river. The entrance to the building was relocated to the north side to facilitate pedestrian flow through the Visitor Center Complex within the new site, which allowed the south facade to be unobstructed and increase passive solar gains. For building layout, the offices and break room were moved to the south side of the building. The number of cooltowers was reduced to three including the one for the Comfort Station because the building engineer concluded that there would be sufficient airflow with fewer towers. For architectural reasons, the amount of north and west glass increased, although the tree canopy and building shading keep these surfaces shaded most of the summer. Finally, the outdoor cooltower was removed, with the two cooltowers being expected to condition both inside and outside spaces. A study indicated that the cost of propane in Springdale would exceed that of electric resistance heating. This prompted conversion of the building to an all-electric one, eliminating the fuel storage from the site. However, this determination is contingent upon restricting use of resistance heating during only those nighttime periods when additional demand charges are not imposed. To complement heat obtained from the Trombe wall, electric radiant panels were installed in the ceiling on twelve zones. The cost of zoning the spaces was minimal and provided for control flexibility in controlling building demand. The result was an HVAC system requiring no ductwork or mechanical spaces - saving money and allowing for uncluttered ceiling spaces.

Transfer fans (from the offices to the main space) were installed to pull air from the main space to the offices. Transfer grilles were installed between the break room and the main space to cool the break room and offices. After the building was operated for a year, fans were added to these transfer grills to augment the natural ventilation.

The building was not resimulated as instructed in the ten-step design process, which will be detailed in the design critique section. The design team carefully reviewed all drawings and documents to ensure that the altered design intent was clear and minimized any possible errors or misinterpretation of the design during construction. The creation of the base cases and redesigns are detailed in Section 5.3.2.

\subsubsection{Step 8: Bid Documents and Specifications}

An "as-designed" computer simulation was not done of the building at this step, but several items in the plans were checked. These include thermal bridging, control sequences, lighting layouts (compatibility with daylighting system verified), window specifications, and foundation insulation. Window specifications were critical because different windows types were to be installed on the various facades.

\subsubsection{Step 9: Construction}

Although the design was entirely done by the NPS, the role of implementing the plans on behalf of the NPS was contracted to Post, Buckley, Schuh, and Jernigan, Inc. (PBS\&J). A construction manager was assigned to the project to ensure that the building was built according to plan. The construction contract was awarded to Bud Mahas Construction from Salt Lake City. 
As is typical for construction management, the management can identify problems with areas of their expertise. From a construction management point of view, the most important aspect of the building is the structural integrity of the building. Expertise in thermal envelopes and energy equipment was considered second tier. Shop drawings, color palettes, and equipment selection were approved by NPS, Denver Service Center personnel. In addition, NREL staff visited the site several times with the focus of ensuring energy aspects were implemented properly. The impacts of these issues will be discussed in later sections.

In general, the buildings were built according to plan. Several issues did surface including:

- Window glazing specifications were not followed

- The interface between cooltower shutter doors and the BAS were problematic

- The interface between the windows and the BAS were problematic

- The lighting sequencing and zoning did not match the plans

- The metering in the Comfort Station was not compatible with the electrical configuration.

In addition, NREL found several areas where insulation was missing. These areas were corrected as the building progressed. The most notable was extensive damage to the exterior foundation insulation prior to backfilling.

In general, there was good communication between the design team, the construction manager, and the general contractor.

\subsubsection{Step 10: Commissioning and Postoccupancy Evaluation}

There was no formal commissioning of the building's energy features. Lighting was verified to be working as well as basic operation. No formal comparison of the design intent with the as-built building was done.

NREL installed monitoring equipment shortly after occupancy of the building. Through this monitoring, several problem areas were identified. NREL worked with Zion staff to correct as many of these issues as possible. It is a typical problem that buildings are not formally commissioned and the owner is left to correct problems.

The process of NREL interacting with Zion staff also provided the opportunity to transfer knowledge of the design intent to the people operating and maintaining the building. Results of the commissioning and postoccupancy will be discussed with further detail in the evaluation section.

\subsection{Energy Design Process Evaluation}

The first segment of the evaluation assessed the design process itself through a design team questionnaire and round table session. This assessment was used to capture data related to the type of communication and commitment during the design process.

\subsubsection{Energy Design Process Questionnaire Methods}

The goal of the energy design process evaluation was to carry out a systematic assessment of the performance of the design team after completion of the project. A questionnaire and round table session were used to gather information from the design team. These methods were used to capture data related to the 10-step low-energy design process work discussed in Appendix A. This procedure also helped to identify possible problem areas within the process between the energy consultant, building owner, architect, engineer, and building user. 
The first step of the evaluation involved preparing a questionnaire to survey all the design team members. The second step involved developing a structured interview (round table session) to help validate the questionnaire. Note that the structured interview was administered after collection of the questionnaire.

Together, the questionnaire and survey provided the information to:

- establish if the energy design goals were actually achieved,

- identify problematic design processes,

- identify areas of the design process that worked,

- identify design aspects for long-term research and investigation,

- institute corrective actions, and

- determine the level of commitment and understanding amongst team members that is needed for a successful low-energy building.

The end goal of this evaluation was to obtain feedback from the design team to improve the design process in the future.

After the questionnaire and structured interview had both been administered, the submissions were analyzed, with the resulting design process analysis discussed in Section 3.4.2. The questionnaire was issued after completion of the final design, but before the construction was completed. The questionnaire, as shown in Appendix B, was issued to everyone involved in the design process, including the architect, landscape architect, mechanical engineer, electrical engineer, and design project manager.

Results obtained from the questionnaire were also used to establish the presence of either communication problems or where specific design team members had difficulty understanding technical issues.

Specifically, a communication problem exists when design team members have trouble making their ideas clear to other team members (either in writing or during discussions). A technical problem exists when a technology was not properly implemented by the design team. This data can then be analyzed in conjunction with the 10-step process to determine if this breakdown had an overall affect on the success of the design implementation.

The purpose of the round table meeting was to bring together the design team members to discuss issues related to the design process. This qualitative information gathering session included individuals who had daily impacts on the energy design process. The meeting was used to enhance discussion and to bring up points that were either forgotten or too difficult to communicate in the questionnaire. Discussions that took place were related to specific issues in the questionnaire that they wanted to resolve further, or areas not covered in the questionnaire.

The evaluation team compiled questionnaire results and presented them to the design team. These results were used to create in-depth questions based on the topics that generated concern. This format allowed the evaluation team to probe deeper into problems and allowed the interviewees to go into more detail than normally capable within the allotted space on the questionnaire.

\subsubsection{Energy Design Process Questionnaire Results}

Results of the questionnaire and meeting are presented below in summary form. Specific comments about the questionnaire and round table meeting questions are provided in Appendix B. The primary questionnaire objectives are presented below, with specific responses addressing each issue:

1. Establish whether the energy design goals were actually achieved:

During the design process, before the building was occupied, the architect felt that it was important to verify whether the facility would operate according to the design intent. Building operation was a 
concern because the design team was aware of a previous NPS project that was designed with similar intent, but failed in operation. Although the need to verify design goals was emphasized, no responders actually provided information about how well these goals were achieved. To fully determine if low-energy goals had been achieved, the measured energy performance was obtained. This is studied and discussed in further sections.

2. Identify problematic design processes:

Deviation from traditional expectation and industry norms in materials selection and construction techniques were at the forefront of problems revealed by the questionnaire and meeting. Some individuals involved in the design process found it difficult to deviate from standard procedure. Unconventional building design coupled with the high cost of the cooltowers was initially a cause for apprehension because similarly designed facilities built previously had failed to perform adequately.

Several individuals felt the design process could be greatly optimized by giving project members information ahead of time about available technologies, prior to initiation of the project. Because some features were implemented late in the design process, their appearance was awkward and difficult to integrate into the architecture. Increased communication with designers needs to be emphasized in the future in order to promote a more integrated design. Detailed information about the local environment should also be made available to reduce the chances of over sizing the mechanical design. The excess use of technical details should be avoided in order to prevent the possibility of alienating stakeholders and decision makers. For future projects, energy features should be brainstormed by the team and then evaluated by the energy consultant before a charrette is used to incorporate the features.

In addition, design team effectiveness could potentially be improved by using better time management. A beneficial strategy to improve time management would be to coordinate the progress of all disciplines involved. A deeper exploration of sustainable practices and technologies beyond those currently applied, and retention of current team members in future endeavors, could also enhance team efficacy.

In general, requests for a closer look at broadening materials selection practices were a recurring theme. Concerns about the building control systems were also an issue. Some project members felt longevity may become an issue in the next 5-10 years, while others were simply concerned about how late the control system was conceived in the design process. The team wanted more information on material issues that was not available.

3. Identify areas of the design process that worked:

The individual enthusiasm of the team members as well as the motivation of ZNP staff all contributed to the development of a viable sustainable design for the Visitor Center Complex. However, it was the innovative nature of the project, which many viewed as an opportunity to push the envelope of sustainability, which led to a sense of team cohesiveness among the participants. During design and construction, many novel approaches were applied in an effort to conserve resources. One such approach involved relocating traditionally interior visitor functions to the outdoor environment, resulting in reduced facility dimensions with a comparable reduction in energy use.

All questionnaire responders thought that their ideas were well received. For example, the mechanical engineer was pleased with how well the team received his proposal for heating the Visitor Center with electric radiant panels. Additionally, all responders unanimously felt that the design team interacted and worked well with each other. NREL responded to a majority of team requests with accuracy and speed. In addition, NREL played a significant role in facilitating this by serving as a single point of contact for team communication related to energy issues. This structure allowed reviews, subconsultants and technical information to be distributed very quickly. Occasionally, 
substantial demands for the energy simulations were cause for minor delay, but did not end up posing a significant threat toward the progression of ongoing activities.

NREL's participation in the project was deemed essential for achieving success in the design. The background and vision provided were useful in attaining both a functional as well as visually appealing design. This took the form of critical input regarding progress of the design process from early stages to project conclusion. Specifically, information about passive solar heating output and mass storage calculations were important to drive the design.

4. Identify design aspects for long-term research and investigation:

One responder identified increased solar electrical generation as a potential design aspect to be researched further. Another issue identified was the complexity of the building control system. The mechanical engineer was "skeptical on how the digital controls for daylighting, ventilation, and heating will work in 5 or 10 years."

5. Identify corrective action:

Specific suggestions for corrective action were not identified through the questionnaire or meeting, although corrective actions have been identified and implemented during the post occupancy continuous commissioning process. These corrective actions, as well as the causes of the identified problems, are discussed in further sections. One responder did feel that it would be best if the original team members were involved in future enhancements of the project.

Additionally, the project architect had expressed a need "to evaluate the facility during post construction operation to determine its success and recommend any modifications that may be needed to increase its efficiency." This step is already a current part of the low-energy design process.

Several recurring comments from the questionnaire reinforced this obligation to review and document results with respect to initial design goals. It is noted that this feedback to the design team is often omitted. It is important from a design perspective to determine whether application of the low-energy design process resulted in measured energy savings during a typical period of operation.

6. Determine the level of commitment and understanding among team members that is needed for a successful low-energy building:

Overall, communication took place successfully and problems encountered were virtually nonexistent. The energy consultant played an effective role in communicating ideas and recommendations to the design team, as well as selling the sustainable goals and concepts. This was largely responsible for eventual funding of the project, and helped provide added value to the original design. 


\section{As-Built Building Description}

The as-built Visitor Center Complex includes the Visitor Center, the Comfort Station (public restrooms), and a Fee Station for people entering ZNP, Figure 4-1. This section describes the as-built Visitor Center Complex and its incorporated energy features.

The design team insulated the building envelope well to minimize heating and cooling loads. Cooling is accomplished with natural ventilation via operable clerestory windows and shutter doors on the bottom of the cooltowers. The cooltowers use direct evaporative cooling with buoyancy-driven forces-like a reverse chimney. The design team also engineered the window overhangs to minimize summer solar loads and allow winter passive solar gains.

For building heating, the design team sized the windows to provide daylighting to most of the spaces, not only to provide natural light, but so that heat from sunlight entering the building could be absorbed by the building's thermal mass material such as Trombe walls and tile floors. Heating is further supplemented by electric radiant panels. Providing radiant sources provides comfort at a cooler set-point temperature.

A roof-mounted PV system offsets building electrical loads and ensures a power supply during the frequent utility grid outages caused by thunderstorms. Electrical loads are controlled by a BAS that maintains the energy-efficient lighting system as well as the heating and cooling systems. The BAS also monitors energy consumption and environmental variables for demand limiting and subsequent analysis. Two BASs were installed at the Visitor Center Complex: one in the Visitor Center, and one in the Comfort Station.

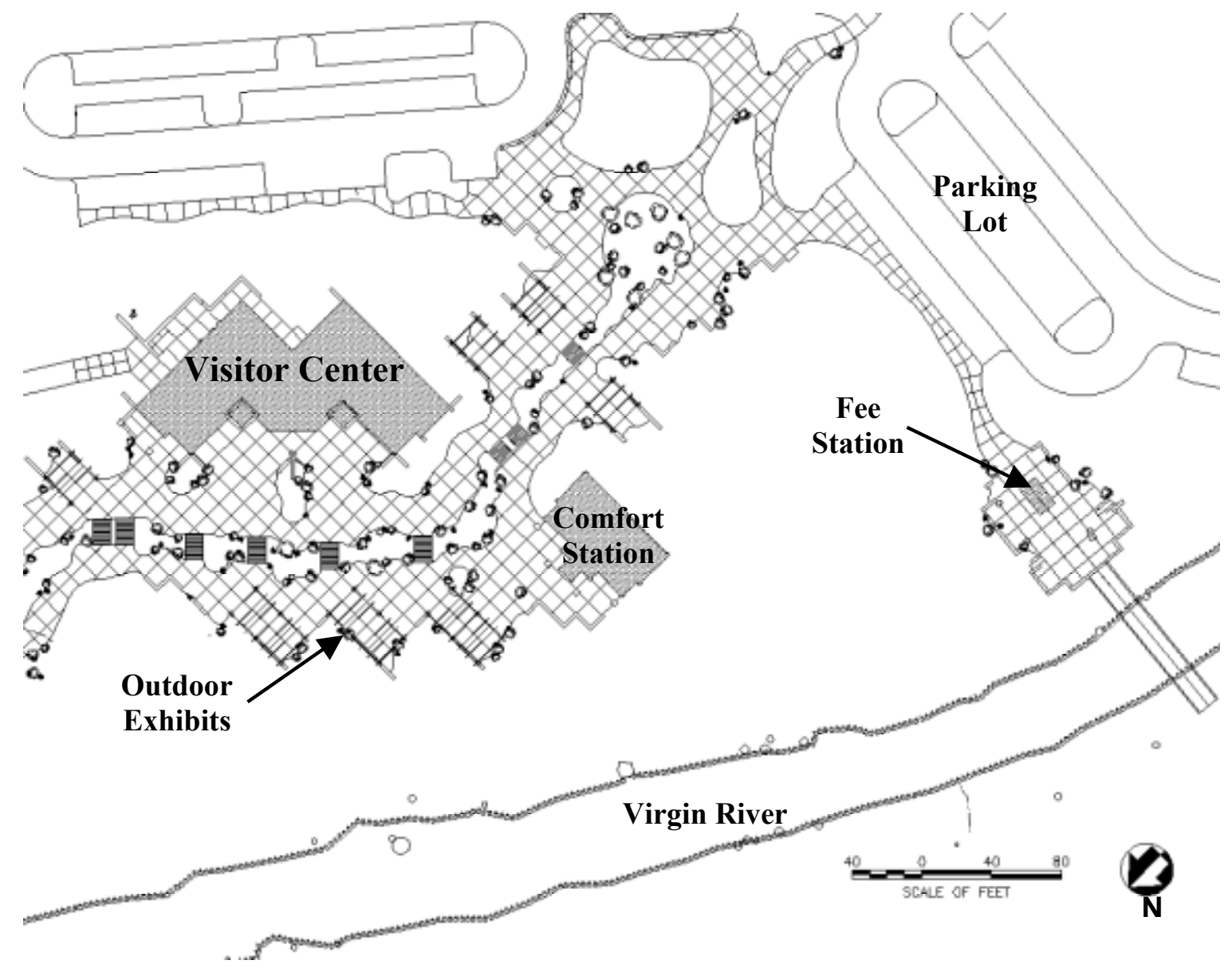

Figure 4-1 Visitor Center Complex site layout 
As mentioned in Step 8 of the design process, the NPS changed the proposed building design substantially because of a building site change, although the major axis was still south facing. The design team had to rearrange the buildings at this point, maintaining as many of the original concepts as possible. However, there was some variation between the original design and what was constructed. Major changes are detailed in Table 4-1.

Table 4-1 Differences between Proposed Design and As-Built Design

\begin{tabular}{|l|c|c|}
\hline & Proposed Design & As-Built Design \\
\hline \hline \multirow{2}{*}{ Size } & $\begin{array}{c}7,600-\mathrm{ft}^{2}\left(706-m^{2}\right) \text { Visitor Center } \\
1,560-\mathrm{ft}^{2}\left(145-m^{2}\right) \text { Comfort Station }\end{array}$ & $\begin{array}{c}8,800-\mathrm{ft}^{2}\left(818-m^{2}\right) \text { Visitor Center } \\
2,756-\mathrm{ft}^{2}\left(256-m^{2}\right) \text { Comfort Station } \\
170-\mathrm{ft}^{2}\left(15.8-m^{2}\right) \text { Fee Station }\end{array}$ \\
\hline Heating & Propane & Electrical Radiant Panels \\
\hline Cooling & 5 Internal Towers & 3 Internal Towers \\
& 1 External Tower & External Towers \\
\hline
\end{tabular}

The new building site required that the design team alter the layout of the Visitor Center building from the original "L" shaped building to the new layout seen in Figure 4-2 and Figure 4-3. The bookstore size was increased, along with the restroom facilities. As discussed earlier, studies showed resistive heating to be cost competitive as long as demand charges were not incurred. The elimination of propane heat allowed designers to avoid allocating space for fuel storage at the facility. Finally, the number of cooltowers was reduced based on cost and expected performance of the cooltowers.



Figure 4-2 As-built Zion layout and energy-efficient features 


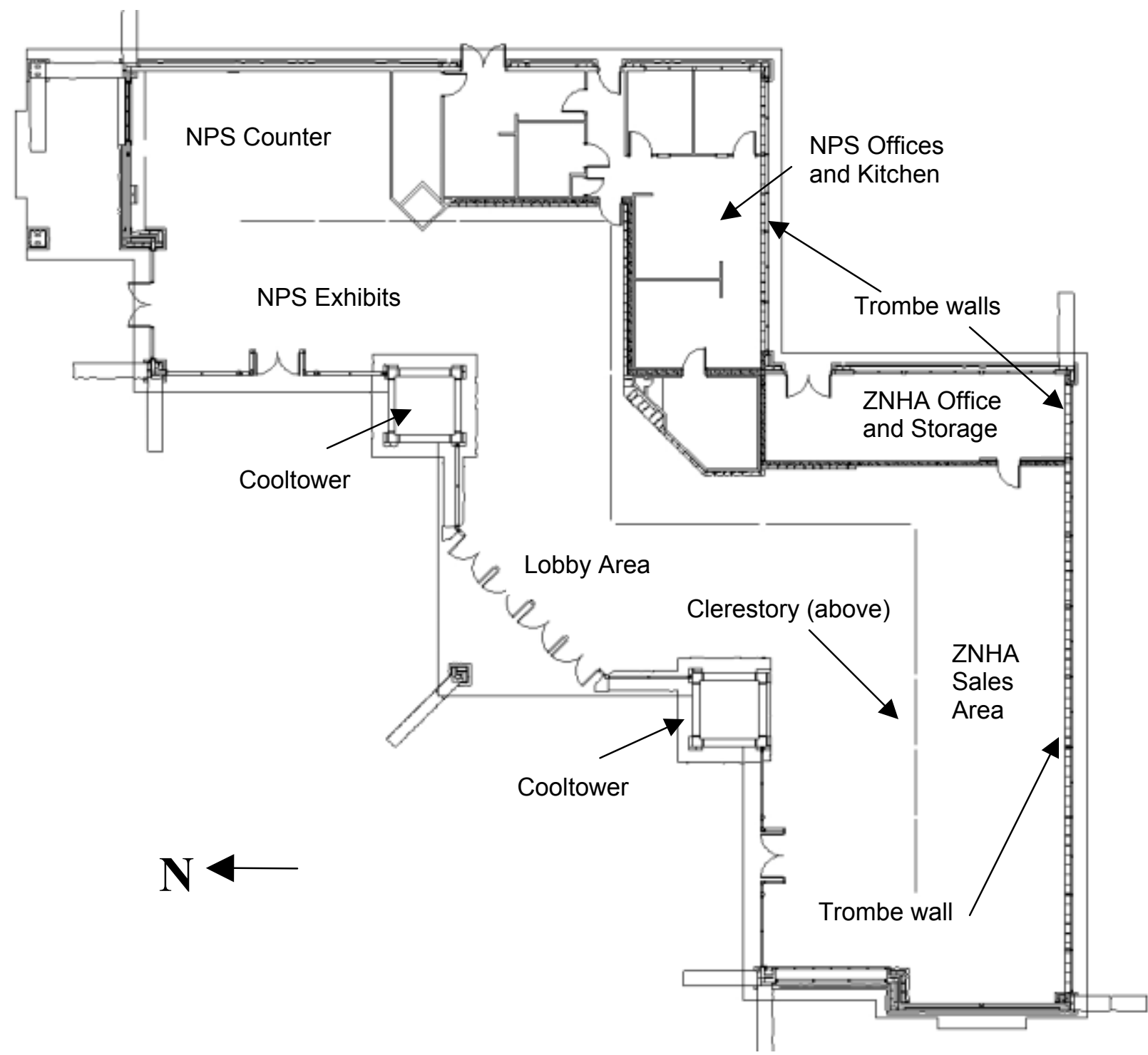

Figure 4-3 As-built Zion Visitor Center floor plan

Adjacent to the Visitor Center is a separate 2,756- $\mathrm{ft}^{2}\left(256.0-\mathrm{m}^{2}\right)$ building for restrooms called the Comfort Station. The Comfort Station includes many features found in the Visitor Center, including a cooltower, a separate BAS, and daylighting (Figure 4-4.) Also included in the Visitor Center Complex is a fee station. This small $170-\mathrm{ft}^{2}\left(15.8-\mathrm{m}^{2}\right)$ structure is located at the entrance to the park. It is included in the building description section because the electric supply for this station is metered along with the rest of the facility. It was not part of the design analysis and was not evaluated as part of this study. 


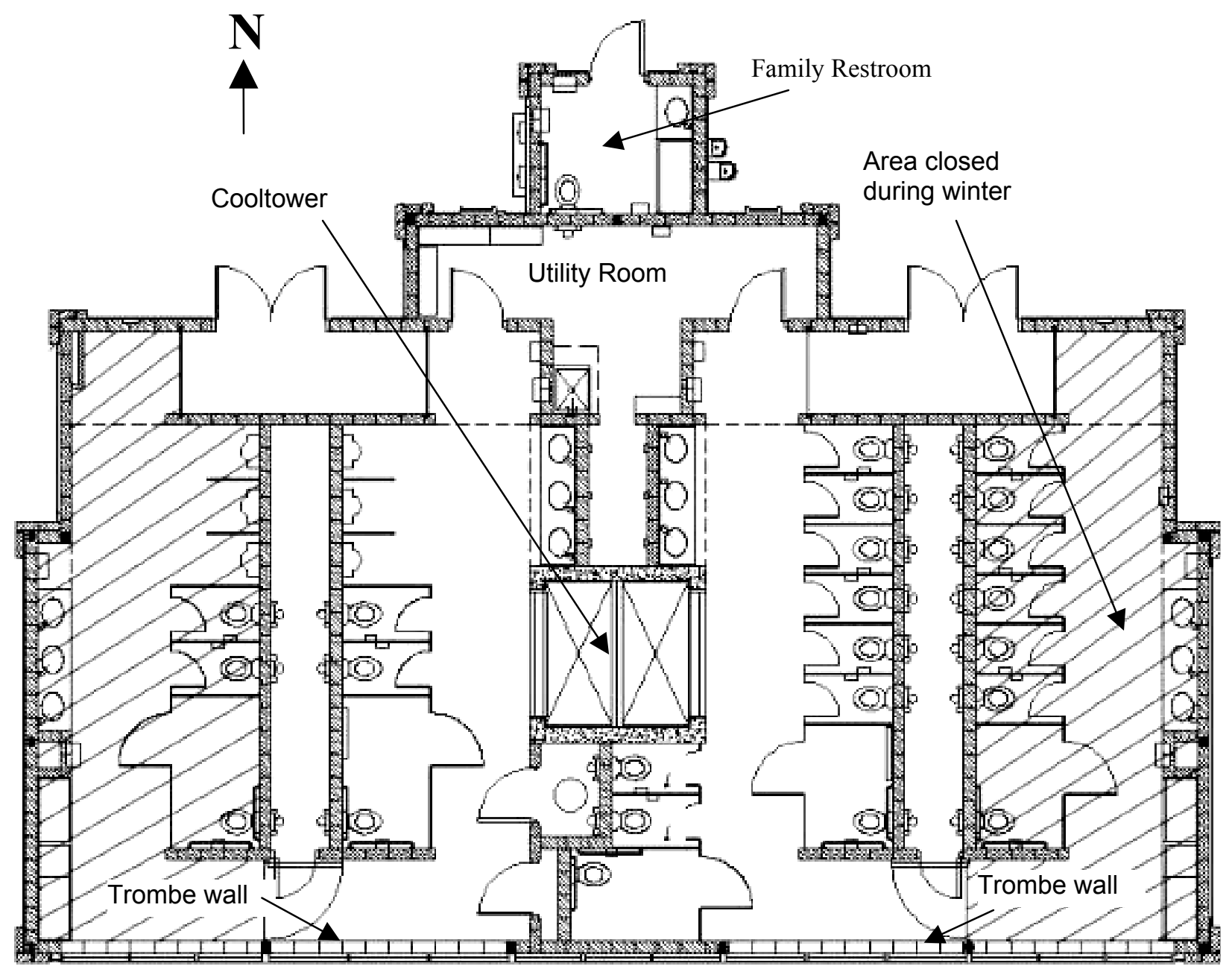

Figure 4-4 As-built Zion Comfort Station floor plan

The total cost to construct the Visitor Center Complex was less than the original program planned building. Integration of energy features into the envelope increased total envelope cost of the buildings; however, the reduction of infrastructure and mechanical systems (including elimination of the mechanical room) reduced costs. This project demonstrates that it is possible to construct sustainable buildings at comparable or less than conventional building techniques.

\subsection{Building Envelope}

The building envelope acts as both the HVAC and lighting systems: window openings in the envelope provide daylighting, operable windows provide ventilation, and the Trombe wall provides heat to the building.

The envelope of the Visitor Center includes R-7 vertically insulated footings. In addition, the first $4 \mathrm{ft}$ $(1.22 \mathrm{~m})$ of slab is insulated to R-7, as shown in Figure 4-5. The walls are 6-in. $(15.2 \mathrm{~cm})$ steel-stud with expanding blown-in-place foam insulation. The exterior sheathing is 1.5 -in. $(3.8 \mathrm{~cm})$ extruded foam for a total wall R-value of $16.5 \mathrm{hr} \cdot \mathrm{ft}^{2}{ }^{\circ} \mathrm{F} / \mathrm{Btu}\left(2.91 \mathrm{~m}^{2} \cdot \mathrm{K} / \mathrm{W}\right)$. Siding covers most of this sheathing. The roof is made of structural-insulated panels that are arranged to sandwich a layer of rigid foam insulation between sheets of oriented strand board (OSB) with an R-value of $30.9 \mathrm{hr} \cdot \mathrm{ft}^{2} \cdot{ }^{\circ} \mathrm{F} / \mathrm{Btu}\left(5.45 \mathrm{~m}^{2} \cdot \mathrm{K} / \mathrm{W}\right)$. This type of insulation results in a well-sealed building. 
The Comfort Station has a similar envelope construction with exception of the walls, which are concrete masonry units $(\mathrm{CMU})$ with insulation filled cores and 1.5 in $(3.8 \mathrm{~cm})$ of rigid foam on the exterior.

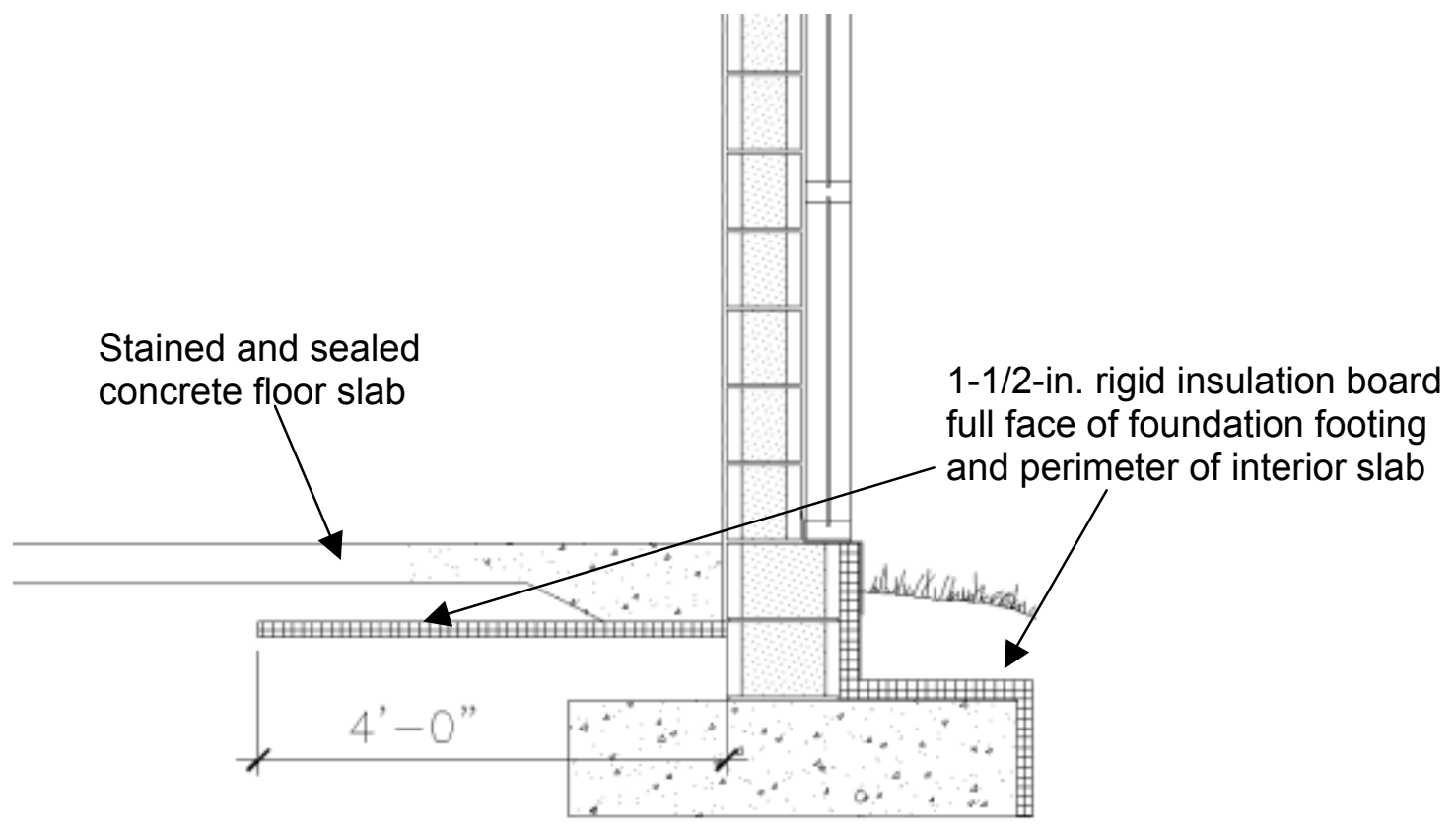

Figure 4-5 Typical slab and footing insulation

Both buildings used high thermal mass (concrete floors) to provide additional capacitance. All walls of the Comfort Station are composed of CMU. Some of the interior Visitor Center walls are also composed of CMU. Both buildings use Trombe walls on the south facade; CMUs are solid filled with concrete. The 8-in. $(20-\mathrm{cm})$ CMUs are covered with a selective black surface on the exterior. This selective surface has a low emissivity and a high absorptivity. A storefront window system provides a single-glazing unit of patterned glass intended to obscure the black Trombe wall.

The building envelope characteristics are detailed in Table 4-2. The only difference between this table and the design was in the south and east windows. These windows were designed to have a SHGC of 0.55 using a low-e coating on surface 3 . The installed windows had the coating on surface 2 , which reduced the SHGC to 0.44 . We discovered this change after the building was completed, but the installer was not willing to correct the error. As a design consideration, proper window testing tools should be provided to the construction manager to verify the performance of the glass before acceptance.

Clerestory windows are a passive part of the lighting and HVAC systems. Computer simulations assisted design of the windows by providing fenestration sizing data according to daylighting requirements.

Sunlight is able to enter in the winter and help keep the space heated. Conversely, overhangs shade the glass from the high sun and shield the facility from unnecessary solar gains during the summer months. The Visitor Center was designed to block west-facing windows from the summer sun. A tree canopy also contributes toward this minimization of heat gain on summer afternoons. Glass with a suspended film was used to achieve very low SHGCs and low U-values to make this glass less of a cooling burden on these facades. 
Table 4-2 Building Envelope Construction and Thermal Properties

\begin{tabular}{|c|c|c|}
\hline Envelope Component & $\begin{array}{l}\text { Constructions } \\
\text { (outside to inside) }\end{array}$ & $\begin{array}{c}\mathbf{R}_{\text {effective }} \\
\mathrm{hr} \cdot \mathrm{ft}^{2} \cdot{ }^{\circ} \mathrm{F} / \mathrm{Btu} \\
\left(m^{2} \cdot \mathrm{K} / W\right)\end{array}$ \\
\hline \multicolumn{3}{|l|}{ Walls } \\
\hline Trombe Walls & $\begin{array}{l}\text { 5/32-in. low-iron patterned Trombe wall glazing, } \\
\text { 2.5-in. air gap, 8-in., grout-filled CMU. }\end{array}$ & $\begin{array}{l}2.3 \\
(0.41)\end{array}$ \\
\hline $\begin{array}{l}\text { Visitor Center } \\
\text { Exterior Walls }\end{array}$ & $\begin{array}{l}\text { Wood siding, } 1 / 2 \text {-in. rigid insulation board, } \\
6 \text {-in. metal stud framing with foam-in-place } \\
\text { insulation, 1/2-in. plywood backing, 5/8-in. Gyp } \\
\text { board. }\end{array}$ & $\begin{array}{l}16.5 \\
(2.91)\end{array}$ \\
\hline Comfort Station Walls & $\begin{array}{l}\text { Wood siding, 1-1/2-in. rigid insulation board, } 8 \text {-in. } \\
\text { CMU with foam insulation cell inserts }\end{array}$ & $\begin{array}{c}6.6 \\
(1.2)\end{array}$ \\
\hline \multicolumn{3}{|l|}{ Windows/Doors } \\
\hline South/East Glass & $\begin{array}{l}\text { Double-pane, } 1 \text {-in. insulating glass with low-e } \\
\text { coating on surface } 2 . \text { Aluminum frames are } \\
\text { thermally broken. SHGC }=0.44^{1}\end{array}$ & $\begin{array}{l}2.3 \\
(0.41)\end{array}$ \\
\hline North/West Glass & $\begin{array}{l}\text { Double-pane heat mirror, 1-in. insulating glass with } \\
\text { thermally broken aluminum frames. SHGC }=0.37 \text {. }\end{array}$ & $\begin{array}{l}2.7 \\
(0.48)\end{array}$ \\
\hline Doors & Non-store-front doors are insulated steel & $\begin{array}{l}11 \\
(1.94)\end{array}$ \\
\hline \multicolumn{3}{|l|}{ Roofs } \\
\hline Typical Roof & $\begin{array}{l}\text { Wood shingles, } 1 / 2 \text {-in. sheathing, } 2 \text {-in. } \times 4 \text {-in. furring, } \\
8-1 / 4 \text {-in. insulated roof panels, } 1 \text { × } 6 \text {-ft wood ceiling. }\end{array}$ & $\begin{array}{l}30.9 \\
(5.45)\end{array}$ \\
\hline \multicolumn{3}{|c|}{ 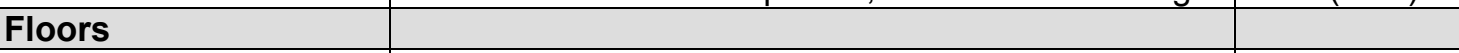 } \\
\hline $\begin{array}{l}\text { All Perimeter } \\
\text { Footings }\end{array}$ & 1-1/2-in. rigid insulation, 12 -in. concrete footing, & $\begin{array}{l}8.3 \\
(1.46)\end{array}$ \\
\hline Slab & 4-in. concrete floor slab. & $\begin{array}{c}0.44 \\
(0.08)\end{array}$ \\
\hline Perimeter of Slab & $\begin{array}{l}\text { 1-1/2-in. rigid insulation, } 6 \text {-in. slab. Horizontal } \\
\text { insulation } 4 \mathrm{ft} \text { from perimeter (See Figure 4-5) }\end{array}$ & $\begin{array}{l}7.6 \\
(1.34)\end{array}$ \\
\hline
\end{tabular}

SHGC was supposed to be 0.55 , but glass was not as specified.

\subsection{Lighting and Daylighting}

The primary source of light in the Visitor Center is daylight entering through clerestory windows and a strip of windows located high on the walls. Electric lighting provides additional light when needed. We selected T-8 lights for most of the main open floor areas, as shown in Figure 4-6. Most of the Visitor Center fixtures are $88 \%$ indirect with $11 \%$ direct (see Figure 4-7). Twenty-four zones of lights allow for different light levels using stepped controls. Each zone has a minimum threshold for operation as well as a time-delay to prevent excessive cycling. In addition, the BAS controls HID spotlights that highlight the Trombe wall, wall displays, and the cooltowers. The entryway of the building also uses these fixtures. We chose fluorescent fixtures for most of the exterior walls, as shown in the lighting plans in Figure 4-9 and Figure 4-10. The offices, back hall, break area, storeroom, and restroom in the Visitor Center use fluorescent fixtures connected to motion sensor controls. The lighting power density (LPD) in the offices is $1.0 \mathrm{~W} / \mathrm{ft}^{2}\left(11 \mathrm{~W} / \mathrm{m}^{2}\right)$ and $0.9 \mathrm{~W} / \mathrm{ft}^{2}\left(9.7 \mathrm{~W} / \mathrm{m}^{2}\right)$ in the bookstore and display areas.

The Comfort Station uses fluorescent fixtures with T-8 lamps. Compact fluorescent cans are located in the entryway and over the sink area, see Figure 4-8. The Comfort Station installed LPD is $1.0 \mathrm{~W} / \mathrm{ft}^{2}$ (11 $\mathrm{W} / \mathrm{m}^{2}$ ). The entire Comfort Station is split into seven zones of lights (not pictured in lighting plan), controlled with the BAS based on occupancy and available daylighting. Exterior lights are bollard fixtures each with a $26-\mathrm{W}$ compact fluorescent lamp. 
The exit signs are 2-W LED fixtures. Egress lighting is provided in the Visitor Center with small battery powered incandescent wall packs. Egress lighting in the Comfort Station uses battery back-up ballasts in a few of these T-8 fixtures.

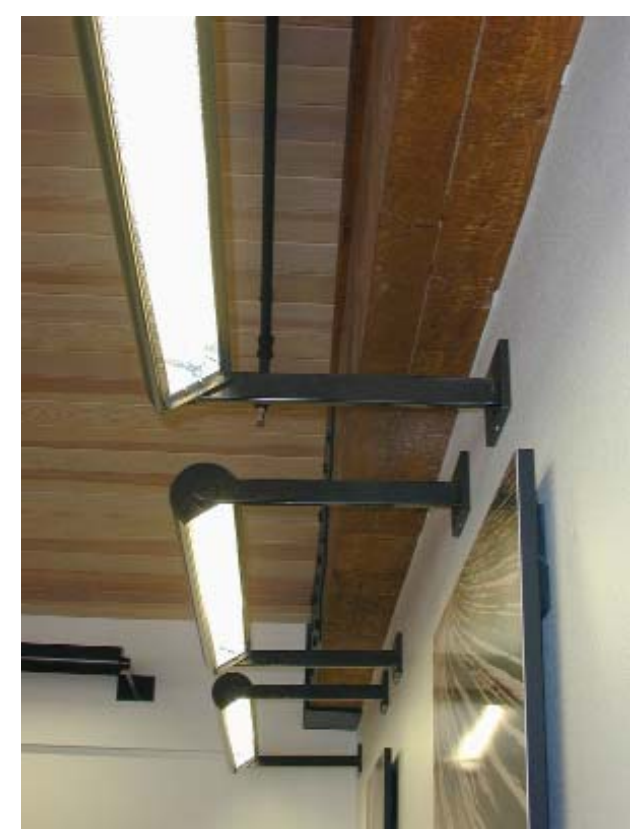

Figure 4-6 Display lighting using 4-ft T-8 Lamps



Figure 4-7 T-8 space lighting (note the dark ceilings and minimal down lighting) 




Figure 4-8 Lighting in Comfort Station

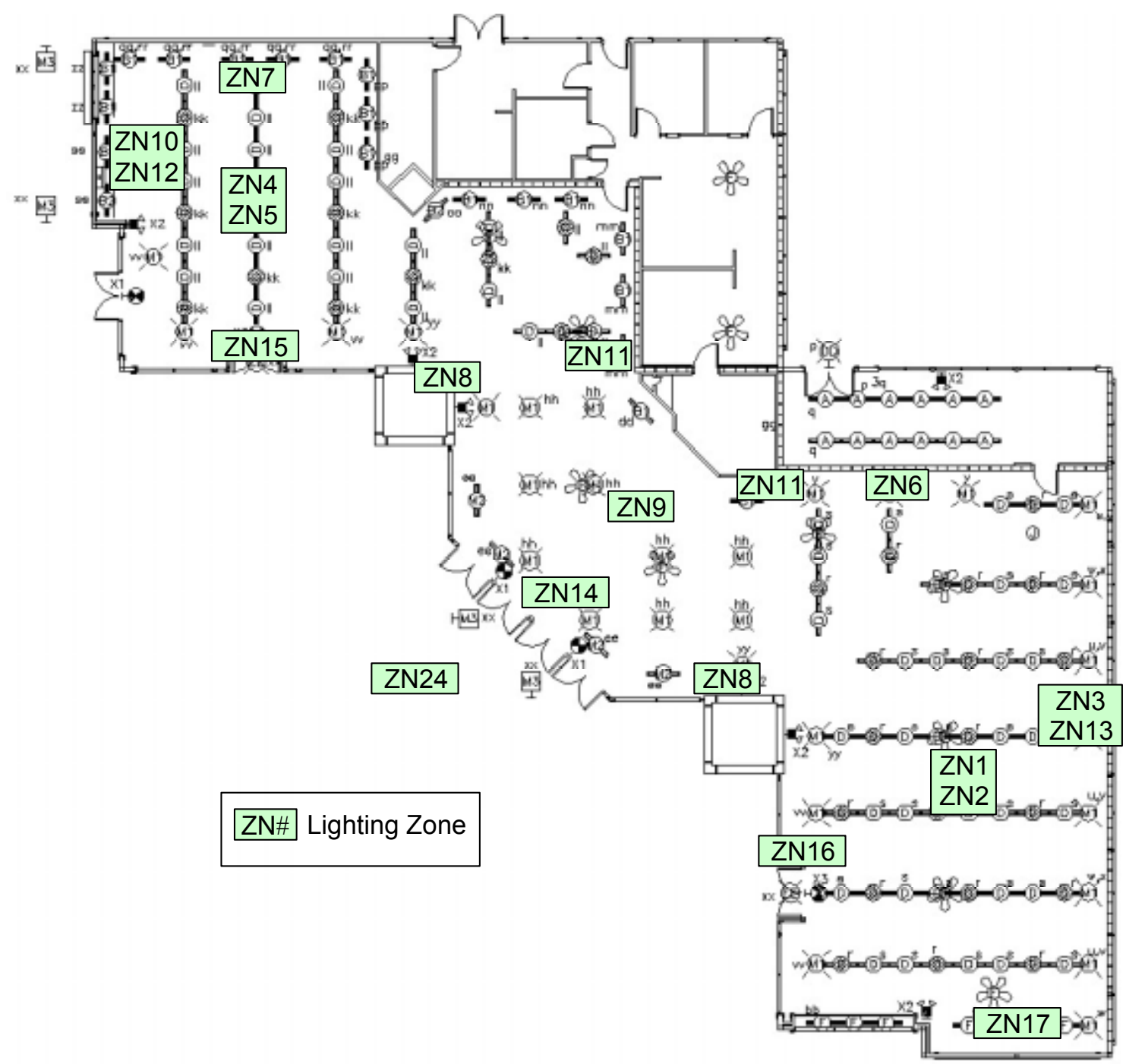

Figure 4-9 Visitor Center lighting plan showing lighting zones 




Figure 4-10 Comfort Station lighting plan 
Table 4-3 Lighting Schedule

\begin{tabular}{|c|c|c|c|c|}
\hline Type & Description & Mounting & $\begin{array}{c}\text { \# Of } \\
\text { Lamps }\end{array}$ & Lamp Type \\
\hline A & Vandal Resistant Lensed Fluorescent & Wall - Surface &  & FO32 / 35K \\
\hline B1 & 4-ft Fluorescent - Asymmetric Distribution & Wall Mounted & 1 & $\mathrm{~T}-8-32$ \\
\hline B2 & 3-ft Fluorescent - Asymmetric Distribution & Wall Mount & 1 & $\mathrm{~T}-8-25$ \\
\hline C & 2-ft x 2-ft Parabolic Fluorescent & Ceiling - Lay in & 2 & FB031 / 35K \\
\hline D & Fluorescent Uplight & Pendant & 1 & F032 / 35K \\
\hline$E$ & Keyless Porcelain Lamp Holder & Ceiling - Surface & 1 & F13DTT/ D835 \\
\hline $\mathbf{F}$ & Compact Fluorescent Track Light & Ceiling - Track & 2 & 27W BIAX \\
\hline G & Undercabinet Fluorescent & Cabinet - Surface & 1 & FO32 / 35K \\
\hline $\mathbf{H}$ & High Abuse Wraparound Fluorescent & Ceiling - Surface & 2 & FO32 / 35K \\
\hline $\mathbf{I}$ & Vandal Resistant Fluorescent & Ceiling - Surface & 2 & FO2 / 35K \\
\hline $\mathbf{J}$ & Compact Fluorescent Track Light & Ceiling - Track & 1 & $39 \mathrm{~W}$ T5 \\
\hline $\mathbf{K}$ & Fluorescent Light & Deck - Surface & 1 & FO32 / 35K \\
\hline $\mathbf{L}$ & Lensed Wet Location Fluorescent Wallwasher & Ceiling - Recessed & 2 & F13DTT / D835 \\
\hline $\mathbf{M}$ & Fluorescent Flood & See M1, M2 \& M3 & 1 & \\
\hline M1 & Metal Halide Monopoint & Ceiling - Surface & 1 & 35W PAR38 \\
\hline M2 & Suspended Cable Fluorescent Uplight & Ceiling - Pendant & 1 & F32 T-8 \\
\hline M3 & Low Voltage Mini - Floodlight & Beam Surface & 1 & 13W TFM 3DTT \\
\hline $\mathrm{X} 1$ & Finished Area Exit Light & Wall - Surface & Incl & LED \\
\hline $\mathbf{X 2}$ & Finished Area Emergency Light & Wall - Surface & 2 & DS N080 \\
\hline $\mathrm{X3}$ & Finished Area Exit Light - Pendant & Wall - Pendant & Incl & LED \\
\hline AA & Exterior Fluorescent Pathlight & Ground - Surface & 1 & 22PL120 \\
\hline$A B$ & Exterior Fluorescent Uplight & Structure - Surface & 1 & 22PL120 \\
\hline CC & Exterior Metal Halide Downlight & Ceiling Recessed & 1 & $70 \mathrm{MH} 120$ \\
\hline DD & Exterior Fluorescent Downlight & Wall - Surface & 1 & CF26DT / 835 \\
\hline FF & Exterior Compact Fluorescent Downlight & Ceiling Recessed & 1 & 13 DTT \\
\hline
\end{tabular}

\subsection{PV Description}

Unreliable power at the park's remote location created a need for a building UPS system. Therefore, during the design process, designers anticipated the addition of a future PV system. The roof on which the system was to be mounted was pitched at a slope to maximize annual PV performance, as shown in Figure 4-11. We also included wiring conduit and roof brackets in the initial design that were installed during construction. Although the initial building plans did not have a central UPS system, conduit was installed so that it, along with a PV system, could be easily installed when funds became available.

Just after completing the building construction, funds became available to purchase a 7.2-kW PV array along with the inverter system. Proper advance planning resulted in a quick installation of the PV modules and integration of the PV array with the building structure and electrical system. 


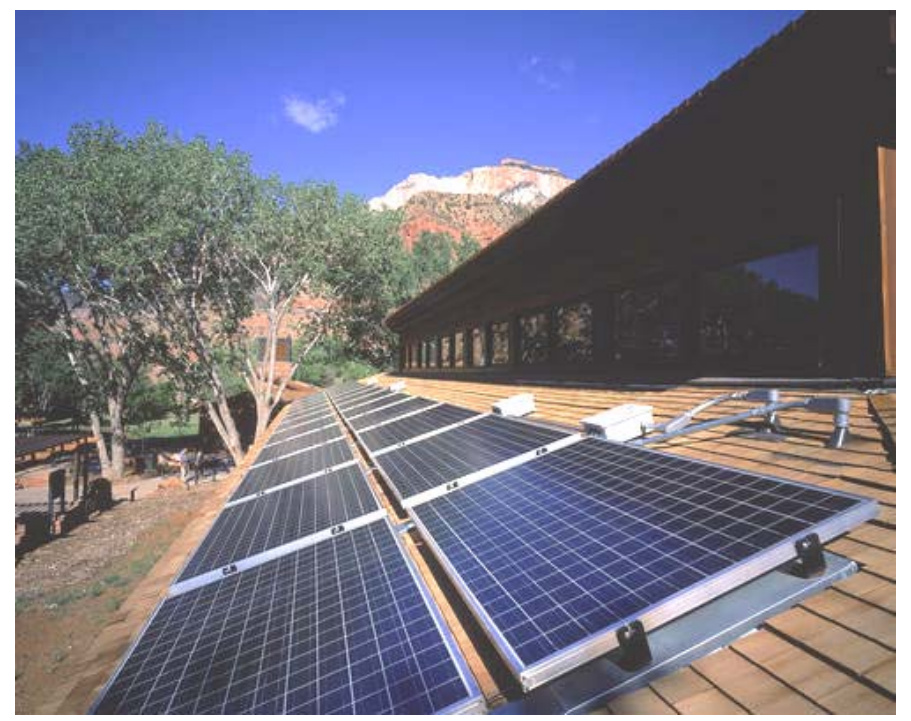

\section{Figure 4-11 PV panels installed on the roof at the Visitor Center}

The roof-mounted, grid-tied PV system is mounted to the south roof of the Visitor Center nearly flush with the 4/12-pitched roof $\left(18.4^{\circ}\right)$. The array is composed of $24,300-\mathrm{W}$ modules divided equally into two subarrays. The subarrays are configured identically — an east array and a west array. Each subarray is rated for 3,600 W and consists of three parallel strings composed of four modules in series to create a nominal 48-V system. Figure 4-12 diagrammatically shows that one subarray charges the building UPS system batteries and provides electricity to other building loads. The other subarray is tied directly to the building electrical panel and does not function as a back-up circuit. The UPS system contains 200 Ah of battery capacity, enough to run the UPS for several hours without solar insolation. With a normal PV contribution, the system will run indefinitely during daylit hours.

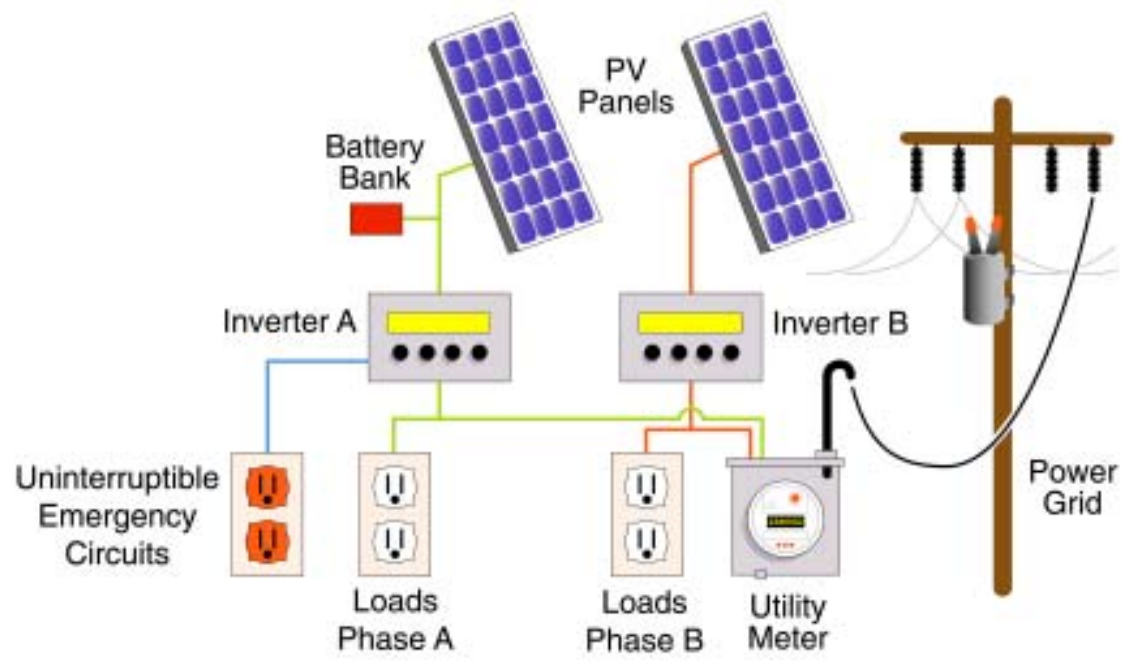

Figure 4-12 PV system configuration

Excess power produced by the PV system is fed into the utility grid. ZNP has a net-metering agreement with the local utility so that it receives credit from the utility for excess power produced by the system. This agreement was the first net-metering agreement to be placed in the state of Utah. 


\subsection{Mechanical Systems}

The HVAC systems for the Visitor Center and Comfort Station have the same design strategies. The design simulations indicated that the Trombe walls would meet most of the heating load for both buildings. Originally, propane burners were specified to provide the remaining heat. However, the cost of propane was similar to the electricity consumption cost. Therefore, electric resistance panels were designed to meet the remaining load, creating an all-electric building. Each heating zone has a temperature sensor that corresponds to the radiant panels.

The cooling load is met by natural ventilation and down draft evaporative cooltowers. For cooling purposes, the radiant panel sensors are averaged into the north part of the building and the south part of the building to correspond with the cooltowers. Ceiling fans are used to help circulate air. Sensors located on the ceiling are used to control these fans.

\subsubsection{Trombe Wall and Heating Panels}

The Trombe wall provides a significant portion of space heating. Radiation from the sun is absorbed and stored in the masonry wall. The collected heat is then released back into the building when the temperature drops later in the day. The exterior sheet of glass and a black selective coating help to reduce heat loss from the exterior of the Trombe wall to the environment, see Figure 4-13 and Figure 4-14. The temperature of the inside surface of the Trombe wall can reach over $100^{\circ} \mathrm{F}\left(37.8^{\circ} \mathrm{C}\right)$ in the winter. This warm surface provides radiant comfort to the visitors. Electrical radiant ceiling panels provide supplemental heat during periods of low solar resources when the Trombe wall does not meet the heating load. The performance of the Trombe wall can be seen in Section 6.1.2.

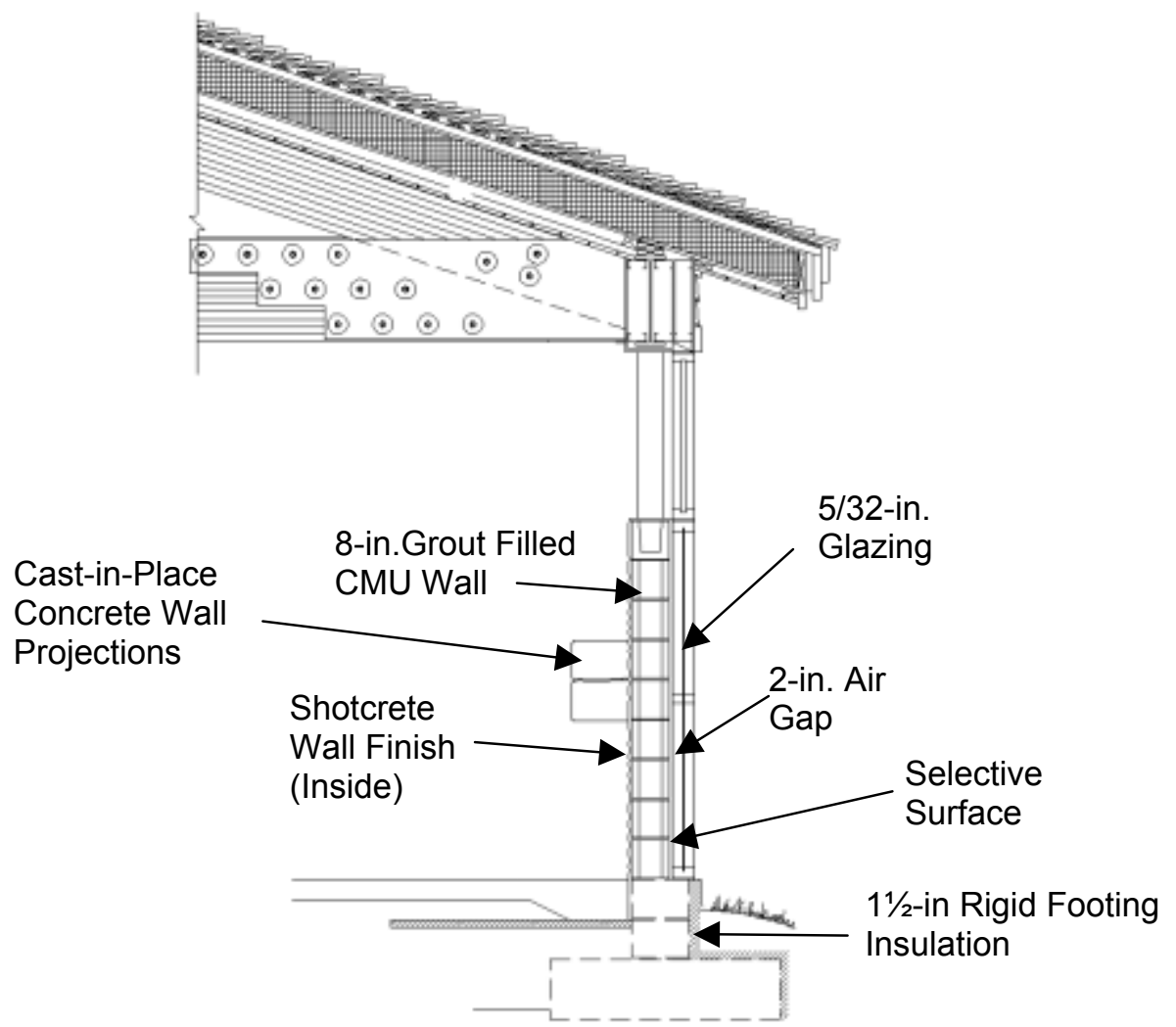

Figure 4-13 Cross-section of Trombe Wall

The location of the Trombe wall footing insulation shown in Figure 4-13 is critical, as Trombe wall performance can be diminished due to three-dimensional heat transfer to the ground. By thermally 
decoupling the footings from the ground with insulation, unnecessary heat loss is avoided and more heat from the Trombe wall is supplied to the building.

The performance of Trombe walls is diminished if the wall interior is not open to the interior zones. Based on previous experiences with Trombe walls (Balcomb 1998), the heat delivered by a Trombe wall in a residence was reduced by over $40 \%$ because kitchen cabinets were placed on the interior of the wall. The wall design at Zion includes cast-in-place concrete projections attached to the interior of the wall. These projections were included to ensure bookshelves were not placed against the Trombe wall.

The interior surface of the Zion Trombe wall was selected to maximize heat transfer to the space. Some interior surfacing materials, such as drywall, can reduce heat delivered by Trombe walls due to nonconductive air gaps in between the concrete wall and the interior surface (Balcomb 1998). A shotcrete wall finish was specified to provide a more continuous conductivity throughout the wall.

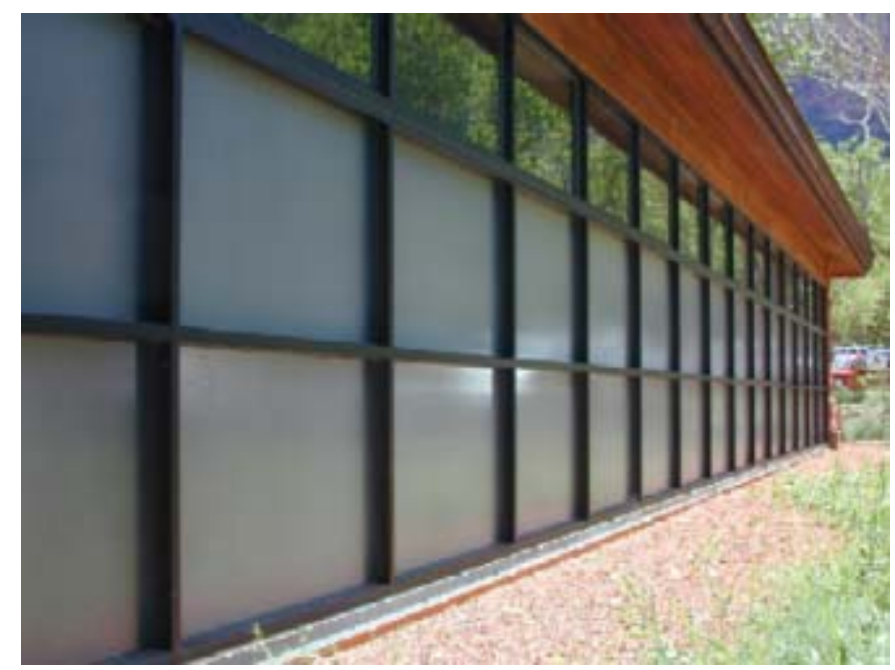

\section{Figure 4-14 Photograph of Trombe wall showing patterned glass over the Trombe} wall, row of daylighting glass, and overhang to shade wall during the summer

\subsubsection{Cooling Systems}

The cooling system functions in two stages. The first stage occurs when the clerestory windows open and natural ventilation cools the space. When natural ventilation is inadequate, the first stage is augmented by using the cooltowers to further reduce indoor temperature (second stage). We designed the cooltowers to operate on natural convection driven by buoyancy forces and prevailing winds. The cooltowers have evaporative cooling pads on all four sides at the top and large operable shutters on all four sides at the bottom. Air is cooled by pumping water over the evaporative cooling pads. This cool, dense air "falls" through the tower and exits through the large openings at the bottom of the towers, as shown in Figure 4-15. The cool air drawn into the building by the cooltowers causes the hot air already inside the space to rise and exit the building through the open clerestory windows.

There are no fans in either of the towers. The only energy required for each tower is a $1 / 3-\mathrm{hp}(249-\mathrm{W})$ pump for water. The building's energy management computer controls the operable clerestory windows, shutter doors, and pumps. The shutter doors on the exterior of the building were intended for cooling the patio area, but they are rarely used because the air entering the patio area dissipated quickly and was not effective. In addition, using the exterior doors degraded the interior performance. Figure 4-16 and Figure 4-17 show the installed towers from the outside and inside the building. Measured airflows from 
each tower are approximately $8,000 \mathrm{ft}^{3} / \min \left(226.5 \mathrm{~m}^{3} / \mathrm{min}\right)$ during typical operation. This number is only an approximation due to measurement difficulties for very low-pressure systems. To approximate the supply air flow from the cooltowers, we used a velocity probe to test air velocity at several different locations on the exhaust air grill.

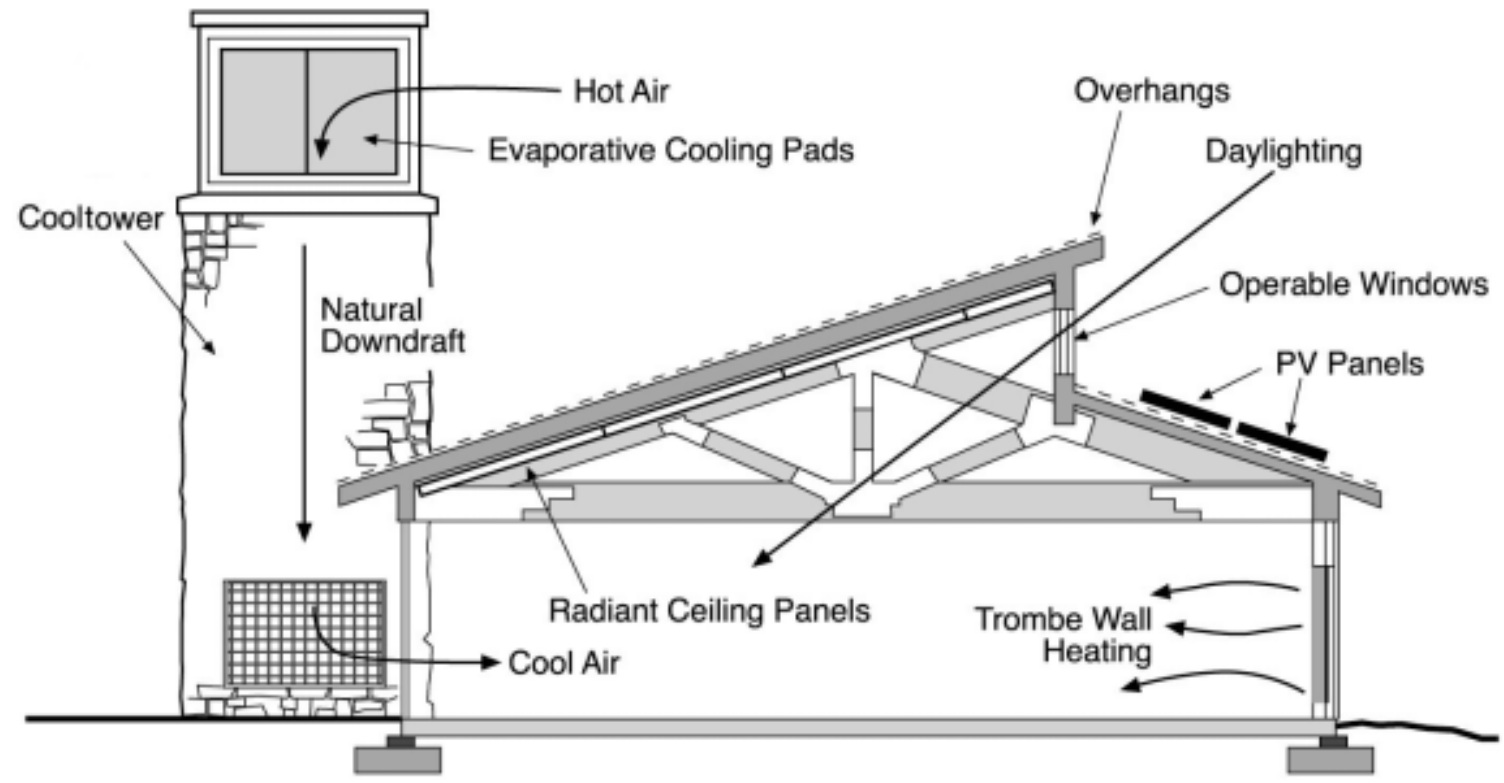

Figure 4-15 Illustration of how the cooltowers work at the Visitor Center

Ceiling fans, controlled by the BAS, are located in the main zone of the Visitor Center as well as the break room. The fans are controlled based upon zone temperatures, and help to keep air moving. We put small fans in the offices to provide additional circulation if needed. These fans exhaust air from the office and dump it into the exhibit area. During the wintertime, the cooltower doors are closed. 




Figure 4-16 Natural downdraft cooltowers - exterior view



Figure 4-17 Interior view of a cooltower showing operable shutters that allow cool air to enter the building through the bottom louvers

\subsection{Equipment}

Electrical loads in the building that are not directly related to heating, ventilation, air conditioning, and lighting are included in the equipment end use category. Electricity is supplied to the equipment loads at the Visitor Center from two sources. The first is a UPS circuit that allows the building to remain 
operational during daylight hours when no power is available. The UPS provides power to the computer equipment, cash registers, window actuators, cooltower pumps, telephone switch, and BAS. The UPS system is integrated with the photovoltaic system discussed in Section 4.3. During power outages, the computer equipment, cash registers, and telephone switch are the minimum equipment required to continue business functions, and the window actuators and cooltower pumps ensure continued operation of the building cooling system. Note that the daylighting system provides sufficient light during most typical business hours.

The other equipment circuit is a non-UPS plug load, which operates noncritical devices such as the hotwater heaters, exhibits, and noncritical computers. The demand for hot water is low. The only need for hot water in the Visitor Center is for cleaning. The need for hot water in the Comfort Station is also limited to cleaning; however, sinks are provided with hot water as a convenience. ZNP staff did not want to provide unlimited hot water that could be used for hair washing and bathing - a common event in these types of facilities. There are three 1.6-kW hot-water heaters in the Visitor Center Complex (one in the Visitor Center and two in the Comfort Station). These heaters are controlled by the BAS for limiting demand. 


\section{Whole-building Energy Evaluation}

\subsection{Whole-building Evaluation Methodology}

NREL, in collaboration with NPS staff, evaluated the Visitor Center Complex from a whole-building perspective. The whole-building evaluation method looks at how building systems affect the energy performance of a building as a whole, rather than looking at how individual systems perform. The evaluation measured the performance of the building during typical operation (Step 10 in the low-energy design process). It included assessing the Visitor Center and Comfort Station measured energy performance from September 1, 2000 to June 1, 2003. The performance study included (1) measuring building end-uses, (2) evaluating lighting and daylighting systems, (3) evaluating the PV system, and (4) assessing occupant comfort. The building evaluation methodology used a conventional building model with measured weather data to calculate energy performance savings from November 2001 through October 2002. Performance indicators analyzed included site energy savings, source energy savings, and site cost energy savings. This evaluation was a crucial step in achieving and verifying the low-energy design goals.

The building did not have a commissioning phase, either by an independent commissioning agent or by the construction management staff. The building, however, was in many ways commissioned as instrumentation was installed and verified. In many respects, this is part of the continuous commissioning process - examining actual data over a long period to continually refine the operation of the building. The staff at ZNP is committed to continually maintaining the building. As shown in the measured data evaluation timeline in Figure 5-1, a complete building energy dataset has been collected since November 2001. Although the system first started collecting data in September of 2000, the dataset was not complete until November of 2001 because of problems implementing the energy meter balance. Additionally, problems with the data recording and collecting with the BAS resulted in unreliable and inconsistent data until November 2001. We addressed this problem by adding energy meters and automating the data collection mechanism. In addition, we downloaded the data several times a day, resulting in redundant data collection and unnecessary phone usage; however, it was necessary for reliable data. The difficult experience of using the BAS to collect energy data shows the importance of employing a reliable data acquisition system. The experience gained in this project indicates that a dedicated monitoring system should be used independent of the BAS. BAS systems are designed to collect information and provide control—not store information for future use.

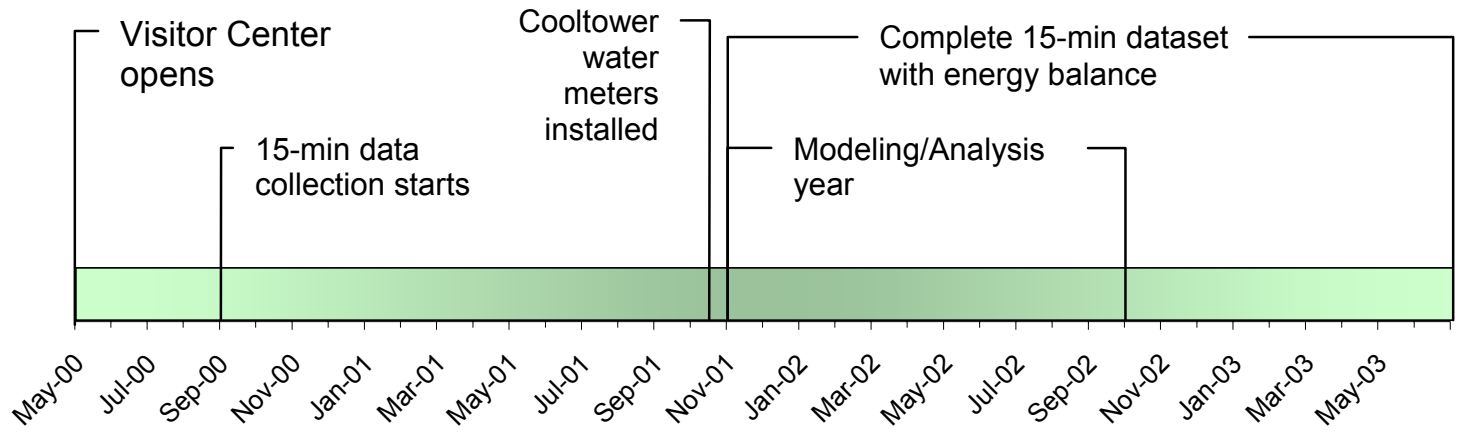

Figure 5-1 Timeline of monitoring system and postoccupancy energy evaluation 


\subsection{Whole-building Monitoring}

\subsubsection{Building Monitoring Methods}

We measured the energy use of the building during typical operation. The energy use metering procedure was necessary to complete Step 10 of the energy design process. The team took energy use measurements at a variety of end-use locations. Energy use measurements were also taken at building energy supply connections from the PV system and the utility company. The building's BAS measured and recorded energy flows every 15 minutes from September 1, 2000 through June 1, 2003.

The Visitor Center monitoring equipment includes watt-hour transducers that measure electricity flows to specific end uses and is recorded with the BAS. The location of each meter is shown in Figure 5-2, with meter descriptions summarized in Table 5-1. End uses are grouped into HVAC, lighting, and equipment loads, and are categorized by color as shown in Figure 5-2. A calculation of an energy balance around the utility meter was made possible by directly measuring the primary end uses in the building. This energy balance accounted for electricity flowing into the building and provided an opportunity to verify metering reliability.

In Figure 5-2 and Table 5-1, the meters are color coded to correspond with measurement technique. The yellow meters represent directly measured energy using a watt-hour meter. The gray meters represent calculated energy, and are typically quantified by recording an on or off signal and multiplying the operation time by the load size based on periodic power tests. Finally, the blue meters are inferred through an energy balance around an electrical node. For the inferred and calculated meters, Table 5-1 provides a description of variables necessary for the calculation process.

We also monitored local environmental conditions. Weather variables monitored included outdoor drybulb temperature, relative humidity, wind speed and direction, and horizontal and vertical irradiance. 




Figure 5-2 One-line electrical system plan and data acquisition meter locations 
Table 5-1 Energy Monitoring Sensor Descriptions

\begin{tabular}{|c|c|c|}
\hline Meter & Loads Measured & Type of Measurement \\
\hline 1 & Total Loads & UPL utility meter (pulse output to BAS) \\
\hline 2 & Total Comfort Station Loads & Measured directly \\
\hline 3 & Visitor Center Light Loads & Measured directly \\
\hline 4 & Visitor Center HVAC Loads & Measured directly \\
\hline 5 & Visitor Center Plug Loads & Measured directly \\
\hline 6 & Comfort Station Light Loads & Measured directly \\
\hline 7 & Comfort Station HVAC Loads & Measured directly \\
\hline 8 & Comfort Station Plug Loads & $\begin{array}{l}\text { Total CS loads minus light and HVAC loads } \\
{[2-(6+7)]}\end{array}$ \\
\hline 9 & Energy to Grid & Measured directly \\
\hline 10 & Energy from Grid & Measured directly \\
\hline 11 & PV Production & $\begin{array}{l}\text { Total Panel E loads minus net energy from grid } \\
{[12-(10-9)] . \text { Includes inverter/battery losses. }}\end{array}$ \\
\hline 12 & Panel E Total Loads & Measured directly \\
\hline 13 & Visitor Center Cooltower Pump Load & Power required to run two 1/3-hp. motors \\
\hline 14 & Panel E Plug Loads & Total to pump and plug minus pump load (12-13) \\
\hline 15 & Comfort Station Heating Loads & $\begin{array}{l}\text { Calculated by the BAS based on how long the } \\
\text { panels are on. }\end{array}$ \\
\hline 16 & $\begin{array}{l}\text { Visitor Center Indoor Computer } \\
\text { Controlled Lights }\end{array}$ & $\begin{array}{l}\text { BAS multiplies number of lights that are on by } \\
\text { the wattage for each light }\end{array}$ \\
\hline 17 & $\begin{array}{l}\text { Visitor Center Outdoor Computer } \\
\text { Controlled Lights }\end{array}$ & $\begin{array}{l}\text { BAS multiplies number of lights that are on by } \\
\text { the wattage for each light }\end{array}$ \\
\hline 18 & $\begin{array}{l}\text { Visitor Center Switched or Motion } \\
\text { Activated Lights }\end{array}$ & $\begin{array}{l}\text { Total Visitor Center light load minus indoor and } \\
\text { outdoor lights }[3-(16+17)]\end{array}$ \\
\hline 19 & Heating Panels & $\begin{array}{l}\text { BAS multiplies number of heating panels that are } \\
\text { on by the wattage for each panel }\end{array}$ \\
\hline 20 & Exhaust Fans & $\begin{array}{l}\text { BAS multiplies the wattage of the two exhaust } \\
\text { fans by the fans' run time }\end{array}$ \\
\hline 21 & Ceiling Fans & $\begin{array}{l}\text { Total Visitor Center HVAC minus heating panel } \\
\text { load and vent fan load }[4-(19+20)]\end{array}$ \\
\hline 22 & Comfort Station Cooltower Pump Load & $\begin{array}{l}\text { BAS multiplies the power of a } 1 / 3 \text {-hp pump by } \\
\text { the pump's run time. }\end{array}$ \\
\hline 23 & Comfort Station Exhaust Fan & Energy required to run the exhaust fan. (7-22). \\
\hline 24 & Fee Station & Measured directly \\
\hline 25 & Comfort Station Domestic Hot Water & Measured directly \\
\hline 26 & Visitor Center Domestic Hot Water & Measured directly \\
\hline
\end{tabular}

\subsubsection{Monitoring System}

We configured the BAS with the input points listed in Table 5-2. The table indicates the type of input point, the name and location of the point in the BAS, and whether the point is used for control. Some points were planned for the system and were not used directly for control. In some cases, the points were used for monitoring. In other cases, they were not used. Table 5-3 shows the expected accuracy by sensor type based on the manufacturer's literature for the sensors. 
Table 5-2 Input Points for BAS and Data Collection

\begin{tabular}{|c|c|c|c|}
\hline $\begin{array}{l}\text { Sensor Type } \\
\text { Location }\end{array}$ & $\begin{array}{l}\text { BAS Control Point } \\
\text { Name }\end{array}$ & $\begin{array}{l}\text { BAS Input } \\
\text { Location }\end{array}$ & Used? \\
\hline \multicolumn{4}{|l|}{ Temperatures (RTD) } \\
\hline VC Zone 2 & VC_ZN2_TEMP & STAT & No \\
\hline VC Zone 4 & VC_ZN4_TEMP & $1 . I P 4$ & No \\
\hline VC Zone 5 & VC_ZN5_TEMP & 1.IP5 & No \\
\hline VC Zone 6 & VC_ZN6_TEMP & $1 . I P 6$ & Yes \\
\hline VC Zone 7 & VC_ZN7_TEMP & STAT & No \\
\hline VC Zone 8 & VC_ZN8_TEMP & 1.IP7 & Yes \\
\hline VC Zone 9 & VC_ZN9_TEMP & $1 . \mathrm{IP} 8$ & Yes \\
\hline VC Zone 10 & VC_ZN10_TEMP & $1 . I P 9$ & Yes \\
\hline VC Zone 11 & VC_ZN11_TEMP & $1 . \mathrm{IP} 10$ & No \\
\hline VC Zone 12 & VC_ZN12_TEMP & 1.IP11 & No \\
\hline VC Zone 13 & VC_ZN13_TEMP & 1.IP12 & No \\
\hline VC Zone 14 & VC_ZN14_TEMP & 1.IP13 & No \\
\hline VC Zone 15 & VC_ZN15_TEMP & 1.IP14 & No \\
\hline CS Zone 1 & CS_ZN1_TEMP & 2.IP4 & Yes \\
\hline CS Zone 2 & CS_ZN2_TEMP & 2.IP5 & Yes \\
\hline CS Zone 3 & CS_ZN3_TEMP & $2 . I P 6$ & Yes \\
\hline CS Zone 4 & CS_ZN4_TEMP & 2.IP7 & Yes \\
\hline CS Zone 5 & CS_ZN5_TEMP & 2.IP8 & Yes \\
\hline CS Zone 6 & CS_ZN6_TEMP & 2.IP9 & Yes \\
\hline North Cooltower & VC_N_TWR_TEMP & 1.IP3 & Yes \\
\hline South Cooltower & VC_S_TWR_TEMP & 1.IP36 & Yes \\
\hline \multicolumn{4}{|l|}{ Outdoor Weather Information } \\
\hline Wind Speed & VC_WIND_SPEED & 1.IP19 & Yes \\
\hline Wind Direction & VC_WIND_DIR & $1 . \mathrm{IP} 20$ & Yes \\
\hline Vertical Solar Insolation & VC_SOLAR_VERT & 1.IP21 & No \\
\hline Horizontal Solar Insolation & VC_SOLAR_HORIZ & 1.IP22 & Yes \\
\hline Outdoor Temperature & VC_TEMP_OUTDOOR & 1.IP23 & Yes \\
\hline Outdoor Relative Humidity & VC_RH_OUT & 1.IP24 & No \\
\hline \multicolumn{4}{|l|}{ Lighting } \\
\hline VC NPS Light Level & VC_NPS_LT_LVL & 1.IP17 & Yes \\
\hline VC ZNHA Light Level & VC_ZNHA_LT_LVL & 1.IP18 & Yes \\
\hline CS Light Level & CS_LT_LVL & 2.IP10 & No \\
\hline \multicolumn{4}{|l|}{ End Uses } \\
\hline $\begin{array}{l}\text { VC Utah Power and Lights } \\
\text { Power }\end{array}$ & VC_UPL_POWER & 1.PP1 & No \\
\hline $\begin{array}{l}\text { VC Utah Power and Lights } \\
\text { Energy }\end{array}$ & VCMTR_UPL & IC1.6 & No \\
\hline VC HVAC Energy & VCMTR_HVAC & $\mathrm{IC} 1.2$ & No \\
\hline VC Heat Energy & VCMTR_HEAT & 1.GV157 & No \\
\hline
\end{tabular}




\begin{tabular}{|l|l|l|l|}
\hline $\begin{array}{l}\text { Sensor Type } \\
\text { Location }\end{array}$ & $\begin{array}{l}\text { BAS Control Point } \\
\text { Name }\end{array}$ & $\begin{array}{l}\text { BAS Input } \\
\text { Location }\end{array}$ & Used? \\
\hline VC Hot-Water Energy & VCMTR_HOTWAT & $1 . G$ 46 & No \\
\hline VC Light Energy & VCMTR_LIGHT & IC1.1 & No \\
\hline $\begin{array}{l}\text { VC Computer Controlled } \\
\text { Light Energy }\end{array}$ & VCMTR_LGTI & $1 . G V 161$ & No \\
\hline VC Outdoor Light Energy & VCMTR_LGTO & $1 . G V 164$ & No \\
\hline VC Panel E Energy & VCMTR_E & IC1.7 & No \\
\hline VC Plug Energy & VCMTR_PLUG & $1 . G V 58$ & No \\
\hline VC Pump Energy & VCMTR_PUMP & $1 . G V 136$ & No \\
\hline PV into Building & VCMTR_PV & IC1.4 & No \\
\hline PV to Grid & VCMTR_PV_B & IC1.5 & No \\
\hline CS Total Energy & CSMTR_GEN & IC1.3 & No \\
\hline CS HVAC Energy & CSMTR_HVAC & $2 . I P 2$ & No \\
\hline CS Heat Energy & CSMTR_HEAT & $2 . G V 170$ & No \\
\hline CS Hot Water \#1 & CSMTR_DHW1 & $2 . G V 30$ & No \\
\hline CS Hot Water \#2 & CSMTR_DHW2 & $2 . G V 31$ & No \\
\hline CS Light Energy & CSMTR_LTS & $2 . I P 1$ & No \\
\hline CS Plug Energy & CSMTR_PLUG & $2 . G V 100$ & No \\
\hline Fee Station Energy & VCMTR_FEE & IC1.8 & No \\
\hline Water & & & No \\
\hline Water into North Cooltower & VC_N_WTR_MTR_1 & $1 . I P 1$ & No \\
\hline $\begin{array}{l}\text { Water out of North } \\
\text { Cooltower }\end{array}$ & VC_N_WTR_MTR_2 & $1 . I P 2$ & No \\
\hline $\begin{array}{l}\text { Water into South } \\
\text { Cooltower }\end{array}$ & VC_S_WTR_MTR_1 & $1 . I P 34$ & Noter out of South \\
\hline Cooltower & VC_S_WTR_MTR_2 & $1 . I P 35$ & \\
\hline
\end{tabular}

Table 5-3 Expected Accuracy of Sensors

\begin{tabular}{|l|l|l|}
\hline Data Type Recorded & Type of Sensor Used & Accuracy \\
\hline Temperature $\left({ }^{\circ} \mathrm{F}\right)$ & Thermister & $\pm 0.36 \%$ \\
\hline Relative Humidity $(\%)$ & Capacitor & $\pm 3 \%$ \\
\hline Amperage $(\mathrm{Amp})$ & Current transformer & $\pm 2 \%$ \\
\hline Energy $(\mathrm{Wh})$ & Watt-hour transducer & $\pm 0.5 \%$ \\
\hline Water Flow $(\mathrm{gal} / \mathrm{min})$ & Turbine pulse meter & $\pm 1.5 \%$ \\
\hline Luminance levels $(\mathrm{fc})$ & Blue enhanced photo diode & $\pm 1 \%$ \\
\hline
\end{tabular}

We configured the monitoring system to allow for redundancy. The energy consumption from the main utility meter was compared to the sum of all the other end-use meters. See Figure 5-2 for the meter configuration. If the differences of these two values were large, then the meters were unbalanced and the data was faulty; however, the energy balance of the installed meters compared very closely to the installed utility meter, as shown in Figure 5-3. This figure is an X-Y plot of the Visitor Center Complex hourly utility meter versus the hourly sum of the end-use meters from November 2001 to February 2003. The comparison of the two meters yielded a $1.4 \%$ error, with a linear correlation of nearly one. The utility meters at Zion are rated to be accurate to $0.5 \%$ of full-scale. Assuming the meters have the same 
scale, then the total error possible of the data is $1.51 \%$. We considered this error reasonable and the data was considered reliable.

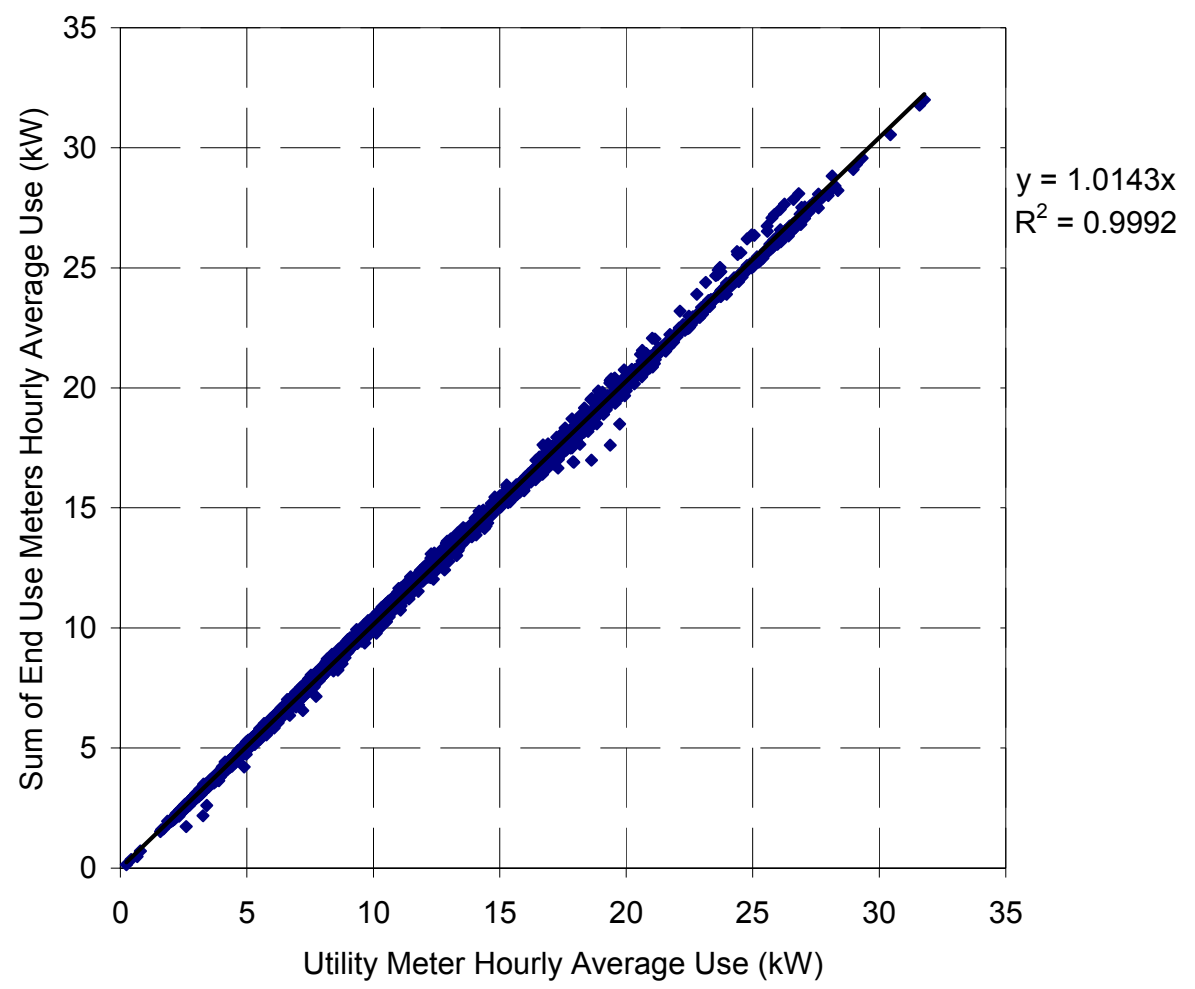

Figure 5-3 Verification of utility and measured data, November 2001 to February 2003

We determined three whole-building energy performance metrics: annual energy cost savings, site energy savings, and source energy savings. We then compared the simulated base-case energy consumption and the measured energy consumption to determine the performance and percentage savings of the building. From the design phase, the original weather data used for the simulations was for Cedar City, UT, located approximately 60 miles from the Zion site. This weather file represented the closest meteorological site compared with Zion. Altitude differences and the canyon effects result in measurable meteorological differences between Cedar City and the Zion site. The temperatures at the Visitor Center Complex during the first two years of measured data were much warmer than the TMY2 data for Cedar City, as shown in Table 5-4 and Figure 5-4. The base case was resimulated using a measured weather file collected at the Visitor Center (November 2001 through October 2002).

Table 5-4 Heating and Cooling Degree Days for Cedar City and Zion

\begin{tabular}{|l|c|c|}
\hline & $\begin{array}{c}\text { HDD } \\
\left(\mathbf{6 5}^{\circ} \mathrm{F} / \mathbf{1 8}^{\circ} \mathrm{C}\right)\end{array}$ & $\begin{array}{c}\mathrm{CDD} \\
\left(\mathbf{7 5}^{\circ} \mathrm{F} / \mathbf{2 4}^{\circ} \mathrm{C}\right)\end{array}$ \\
\hline \hline Cedar City & 6,055 & 65 \\
\hline Zion Measured & 3,435 & 961 \\
\hline
\end{tabular}






Figure 5-4 Comparison of average monthly outdoor temperatures for ZNP Complex and Cedar City

The initial energy savings due to the low-energy design were based on simulations using the Cedar City weather file. Therefore, we designed the heating and cooling systems based on the cooler Cedar City weather. Because of the cooler weather file, the designers felt the design used too many cooltowers; designers removed one of the three original towers in the as-built building, which contributed to some of the cooling problems that will be discussed later. According to step 1 of the low-energy design process, the design team needs to develop a thorough understanding of the local weather patterns. Although the general patterns of weather were well understood, the magnitude of the climate differences was underestimated, resulting in the undersizing of the cooling systems. Reducing the total cooling capacity, combined with additional differences in the proposed design and the as-built design, led to some of the measured summer comfort problems. 


\subsubsection{Measured Data Analysis}

The measured energy consumption and production from November 2001 through May 2003 is shown in Figure 5-5. From November 2001 through October 2002, the annual energy use of the Visitor Center Complex was $92,876 \mathrm{kWh}$, at a site energy intensity of $27.0 \mathrm{kBtu} / \mathrm{ft}^{2} \cdot \mathrm{yr}\left(306 \mathrm{MJ} / \mathrm{m}^{2} \cdot \mathrm{yr}\right)$. The PV system produced $7,860 \mathrm{kWh}$ and met $8.5 \%$ of the total site load. PV production reduced the net site consumption intensity to $24.7 \mathrm{kBtu} / \mathrm{ft}^{2} \cdot \mathrm{yr}\left(281 \mathrm{MJ} / \mathrm{m}^{2} \cdot \mathrm{yr}\right)$. From June 2002 through May 2003, the site energy intensity was $23.8 \mathrm{kBtu} / \mathrm{ft}^{2} \cdot \mathrm{yr}\left(270 \mathrm{MJ} / \mathrm{m}^{2} \cdot \mathrm{yr}\right)$, with PV production meeting $9 \%$ of the total building energy requirements. The net energy use from June 2002 through May 2003 was $21.6 \mathrm{kBtu} / \mathrm{ft}^{2} \cdot \mathrm{yr}(245$ $\mathrm{MJ} / \mathrm{m}^{2} \cdot \mathrm{yr}$ ). The measured site consumption intensity is significantly better than the previously documented ENERGY STAR or top CBECS buildings, and it is comparable to other high-performance buildings, as previously discussed in Section 2.

The energy consumption intensity during the evaluation period decreased during the evaluation period from $27.0 \mathrm{kBtu} / \mathrm{ft}^{2} \cdot \mathrm{yr}\left(306 \mathrm{MJ} / \mathrm{m}^{2} \cdot \mathrm{yr}\right)$ to $23.8 \mathrm{kBtu} / \mathrm{ft}^{2} \cdot \mathrm{yr}\left(270 \mathrm{MJ} / \mathrm{m}^{2} \cdot \mathrm{yr}\right)$. A primary reason for the reduced site energy use was a reduction in heating energy from the winter of 2001-2002 to 2002-2003. As discussed in Section 6.1.2, the occupants reduced the heating set point of the Visitor Center by $2-4^{\circ} \mathrm{F}$ $\left(1.1-2.2^{\circ} \mathrm{C}\right)$ during the winter of 2002-2003. This set-point reduction, combined with a warmer $2002-$ 2003 winter, helped to reduce the overall heating system consumption and improve the whole-building site energy performance, as Figure 5-5 shows.

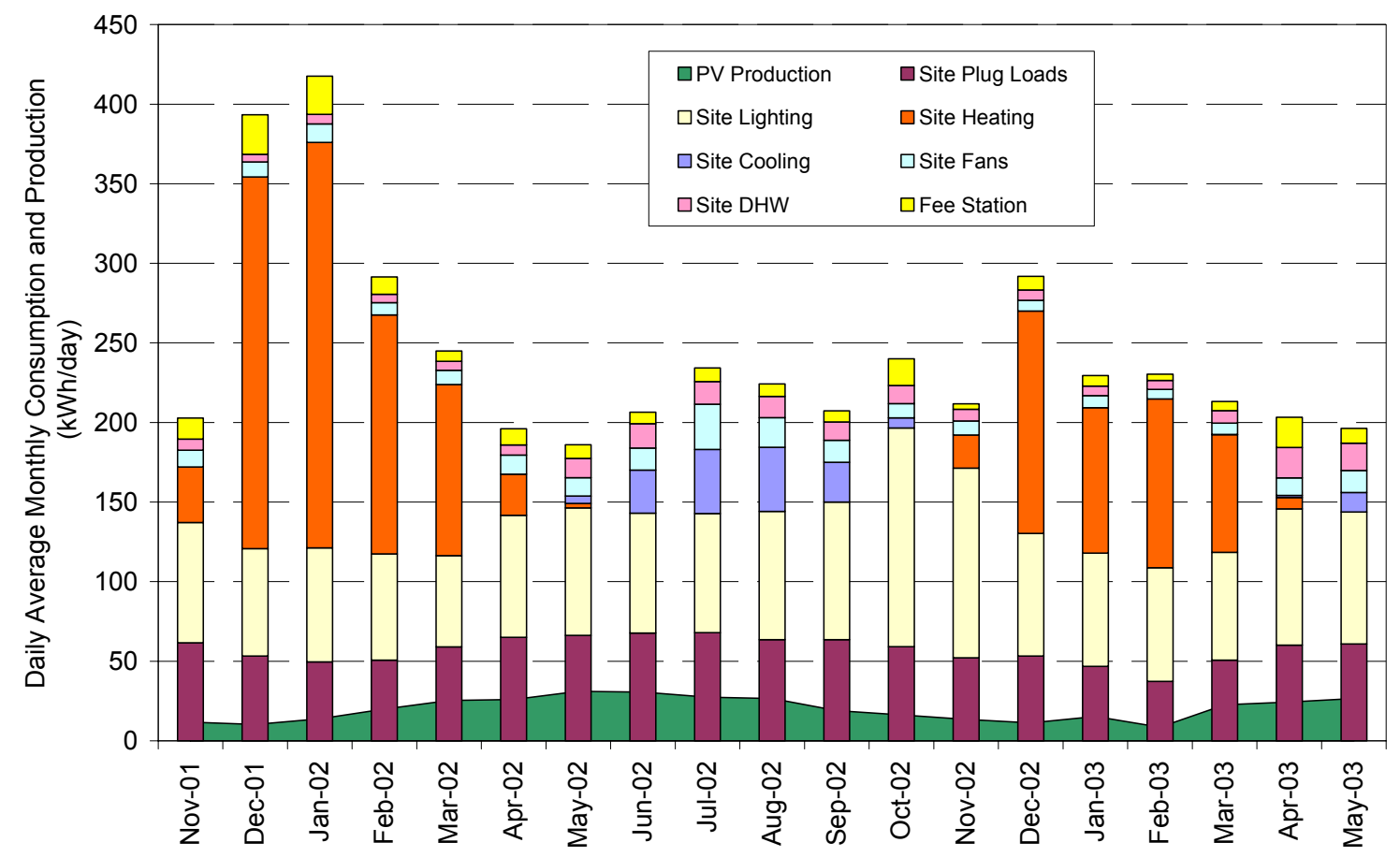

Figure 5-5 End use daily average monthly consumption, November 2001 through May 2003

Figure 5-6 shows the energy consumption distribution by end use from November 2001 through October 2002. The monthly and annual end-use distribution data is shown in Appendix C. The minimal energy consumption of the Comfort Station results in only $15 \%$ of the total site energy consumption, at an energy intensity of $17.4 \mathrm{kBtu} / \mathrm{ft}^{2} \cdot \mathrm{yr}\left(198 \mathrm{MJ} / \mathrm{m}^{2} \cdot \mathrm{yr}\right)$. The Visitor Center heating is the largest single energy end use, with Visitor Center plug loads and BAS controlled lighting the next most energy intensive loads. 


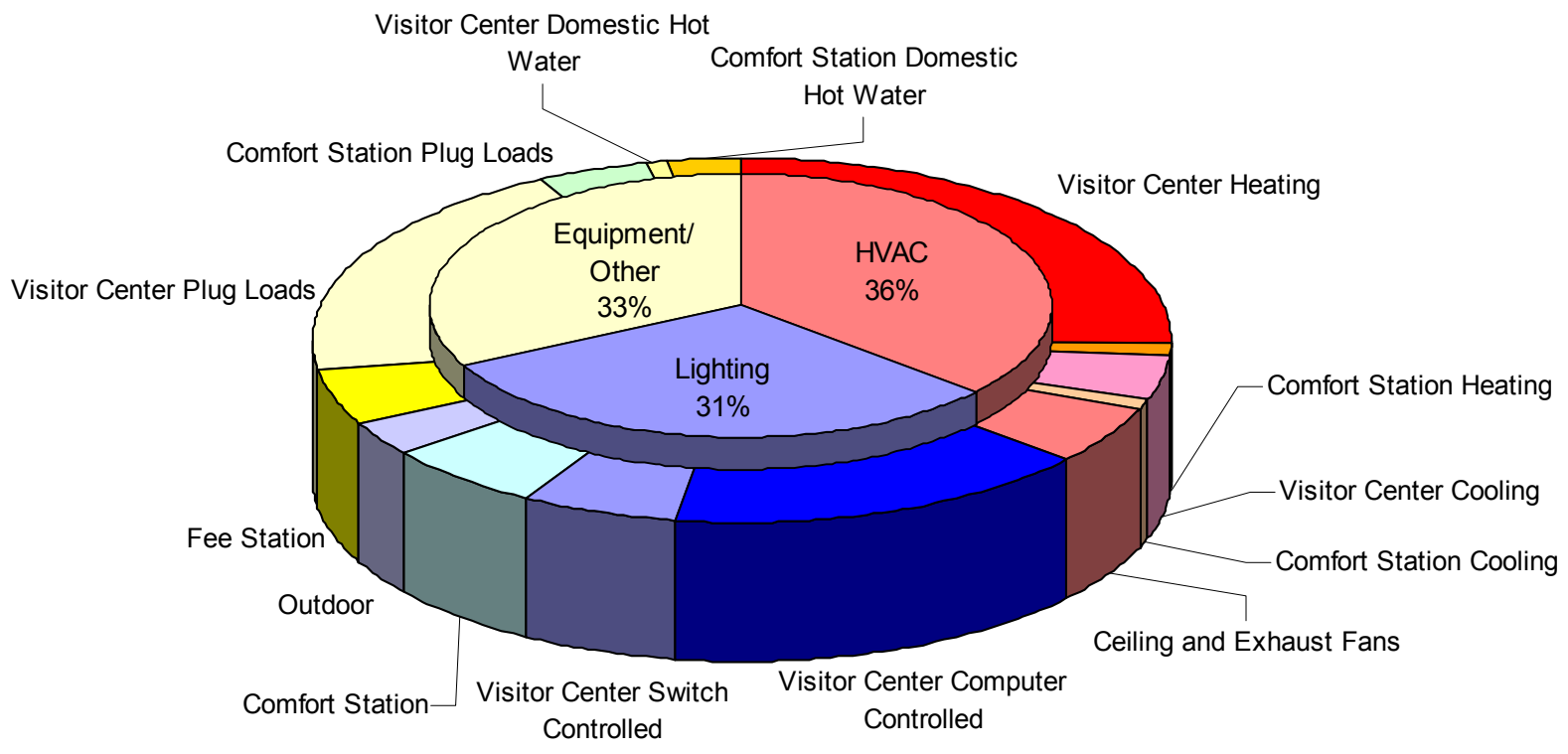

Figure 5-6 Energy consumption by end use, November 2001 through October 2002

The Fee station used 4,632 kWh of electricity annually, or 5\% of the total site use, which included an electric heater, lighting, and equipment. The fee station is included in the site analysis because the energy to this building is supplied through the Visitor Center utility meter.

The total annual energy use for the Visitor Center building, not including the Comfort Station, Fee Station, or outdoor parking lot lights, is $71,399 \mathrm{kWh}$, which results in a building energy use intensity of $27.7 \mathrm{kBtu} / \mathrm{ft}^{2} \cdot \mathrm{yr}\left(315 \mathrm{MJ} / \mathrm{m}^{2} \cdot \mathrm{yr}\right)$. The energy use and energy intensities for each building in the Visitor Center Complex are shown in Table 5-5. A comparison to other buildings is presented in the Executive Summary.

Table 5-5 Energy Use and Intensity for Each Building, Nov. 2001 to Oct. 2002

\begin{tabular}{|l|c|c|}
\hline & $\begin{array}{c}\text { Energy Use } \\
\mathrm{kWh} / \mathrm{Year}\end{array}$ & $\begin{array}{c}\text { Energy Intensity } \\
\mathrm{kBtu} / \mathrm{ft}^{2} \cdot \mathrm{yr} \\
\left(\mathrm{MJ} / \mathrm{m}^{2} \cdot \mathrm{yr}\right)\end{array}$ \\
\hline \hline Visitor Center & 71,399 & $\begin{array}{c}27.7 \\
(315)\end{array}$ \\
\hline Comfort Station & 14,228 & $\begin{array}{c}17.6 \\
(200)\end{array}$ \\
\hline $\begin{array}{l}\text { Total Complex (Including Fee } \\
\text { Station and Outdoor Lighting) }\end{array}$ & 92,876 & $\begin{array}{c}27.0 \\
(307)\end{array}$ \\
\hline
\end{tabular}

\subsubsection{Demand and Energy Cost Analysis}

The easiest method to reduce energy cost in a commercial building is to reduce the peak demand. As seen in Figure 5-13, the demand cost can contribute more than 50\% of the total costs. An efficient building that uses very little energy could still have large demand charges with poor control. In the attempt to minimize the demand costs at ZNP, the evaluation team analyzed all the loads of the building and determined typical use trends. Once the end uses that typically contributed to peak demands were identified, the researchers determined which loads could potentially be shifted until a peak had passed. 
The need for demand limiting controls can be seen in Figure 5-7. The cost associated with demand can be found by taking the maximum power draw over a 15 -minute window multiplied by the $\$ 8.10 / \mathrm{kW}$ demand charge. The peak demand for the winter of 2001-2002 was between 28 and $36 \mathrm{~kW}$, with a typical peak demand day shown in Figure 5-7. The reason the winter peak demand occurred was that all end uses were on at the same time, including the hot water, lighting, and some heating. Although the key contributor to the increase in peak demand was the turning on of lights in the morning, the heat was also on, partially because of the recovery from night set back. In Figure 5-7, the hot water, lighting, and heating were at a maximum for the day during the demand peak. These types of loads offer the most potential for limiting the peak demand because they are not considered essential for short-term operation of the building. Hot water and heating systems can be temporarily turned off during potential periods of peak demand. These loads are not considered essential for short-term operation because these systems use the thermal capacitance of the tank water or the building mass, respectively. The capacitance enables these end uses to be turned off near peak demand periods without significant disruption to the operation of the building. The building thermal capacitance, in the form of massive concrete, is integral to the energy cost savings of the building. During periods of low demand, the hot water and heating systems are turned on. The nighttime heating is only used if the building can be brought back up to a comfortable temperature without incurring a demand charge. This type of control strategy can also take advantage of on-site generation for potential demand reduction by offsetting the utility power draw with on-site generation.

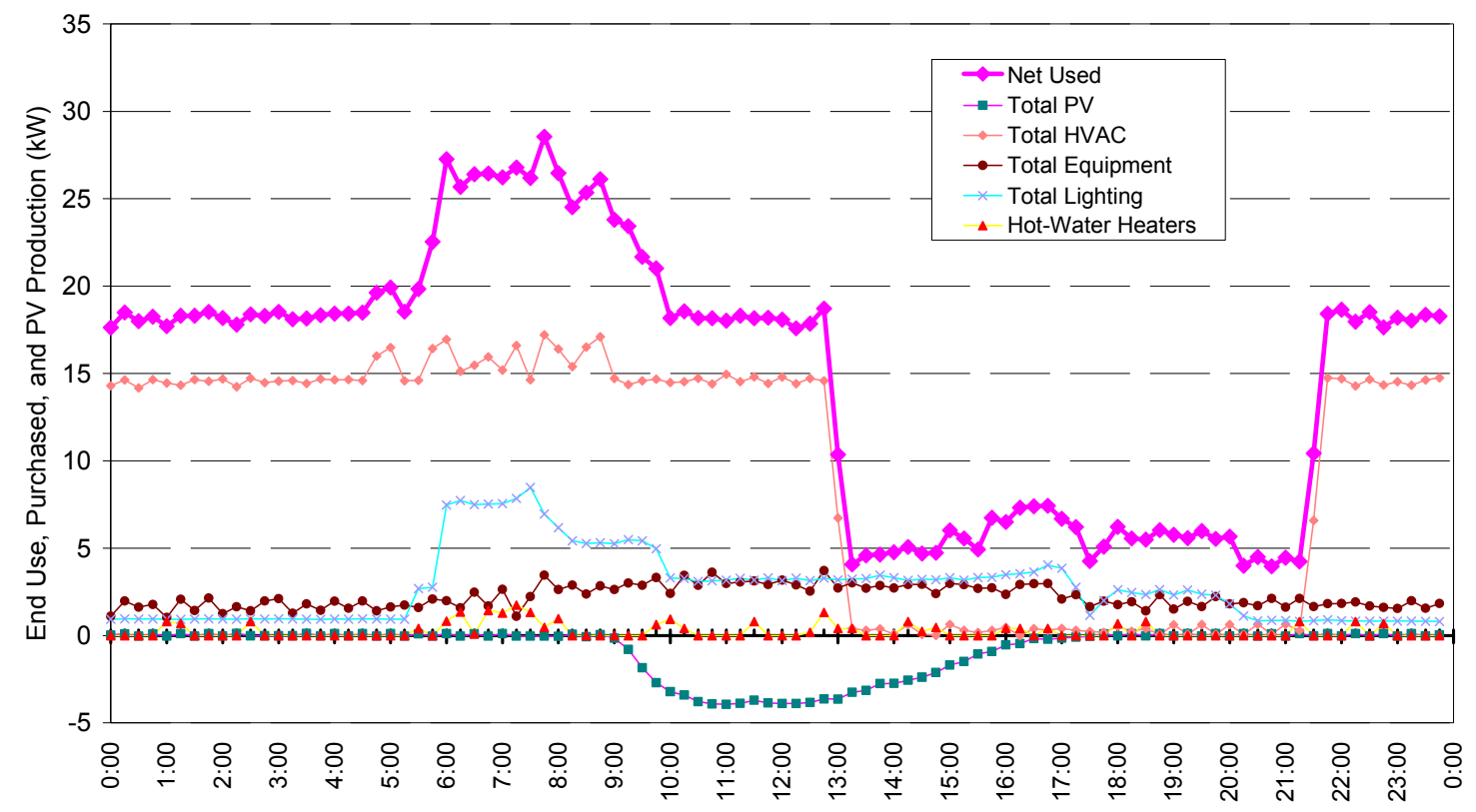

Figure 5-7 Peak demand day without demand limiting controls, February 2, 2002

We implemented the demand limiting controls at ZNP for the winter of 2002-2003 by continuously monitoring total power input to the building from the utility. Demand limiting is accomplished by continuously adjusting the heating set point of the Visitor Center based on the measured building demand. The BAS has the ability to reduce the temperature set point by $0.2^{\circ} \mathrm{F}\left(0.11^{\circ} \mathrm{C}\right)$ every 20 seconds when the demand is near the monthly peak demand. The maximum set point reduction is $10^{\circ} \mathrm{F}$. For example, if the occupants have controlled the heating set point to $72^{\circ} \mathrm{F}\left(22^{\circ} \mathrm{C}\right)$, then the BAS can temporarily adjust the actual set point from $62-72^{\circ} \mathrm{F}\left(17-22^{\circ} \mathrm{C}\right)$. To determine how much the set point is reduced, the BAS 
examines the instantaneous peak and the 10-minute average peak. If the instantaneous demand is greater than $90 \%$ of the previous instantaneous demand, then the heating set point is decreased by $0.1^{\circ} \mathrm{F}\left(0.06^{\circ} \mathrm{C}\right)$. If the instantaneous demand is not greater than $90 \%$ of the previous day peak demand, then the heating set point is not adjusted. Similarly, if the 10-minute demand is greater than $90 \%$ of the 10 -minute peak demand, then the set point is decreased by another $0.1^{\circ} \mathrm{F}\left(0.06^{\circ} \mathrm{C}\right)$. If the 10 -minute demand is less than $90 \%$, then the heating set point is increased by $0.1^{\circ} \mathrm{F}\left(0.06^{\circ} \mathrm{C}\right)$ until it reaches the unadjusted set point. The BAS checks the instantaneous demand every 20 seconds and adjusts the heating set point when needed. Both the weekly 10-minute peak and the instantaneous peak are reset every Sunday morning to $70 \%$ of the previous week's maximum.

The Comfort Station does not use an adjustable set point to control the temperature. During the winter, the building is heated to $50^{\circ} \mathrm{F}\left(10^{\circ} \mathrm{C}\right)$, and during the summer, it is cooled to a minimum of $75^{\circ} \mathrm{F}\left(24^{\circ} \mathrm{C}\right)$. In the winter of 2003-2004, this was changed to use the same set point reduction as the main building.

The domestic hot-water (DHW) units in both the Visitor Center and Comfort Station have demand limiting controls. The DHW is disabled if the instantaneous building demand exceeds the weekly 10minute peak demand. These units will remain off for a minimum of 8 minutes in an attempt to shift the load. If the building demand is less than the weekly peak demand, then the DHW units are enabled. The DHW is mainly used for cleaning and is usually needed early in the morning. The hot water is not considered essential to the normal operation of the building. Before demand limiting, the cleaning crew would empty the hot-water heater for cleaning, causing a spike in the usage early in the morning when the system tried to recover - just as other loads were also peaking. The strategy shifts the hot-water recover to a more advantageous time based on the demand and rate structure.

Figure 5-8 shows the energy consumption of a typical heating day after demand responsive controls were implemented. Similar heating days during the winter of 2001-2002 and 2002-2003 were considered to compare the differences between the building without responsive controls (Figure 5-7) and the building with responsive controls (Figure 5-8). Figure 5-8 illustrates the demand limiting control strategy. Most noteworthy is that when the lights came on in the morning, the heating was reduced to maintain a flat profile. Heating consumption was decreased until daylighting reduced the electrical lighting loads and the PV system provided sufficient energy to limit demand. The total energy used for heating in

Figure 5-7 was $233.7 \mathrm{kWh}$ /day. The total heating energy with demand limiting controls (Figure 5-8) was similar at $232.7 \mathrm{kWh} /$ day. The values are similar because the morning heating load was shifted to a period when the heating system would not incur a peak demand. This shows an effective application of demand limiting because the building still used the same energy but over a longer period; the controls were effective because the peak was reduced significantly. In addition, the typical $1.5-\mathrm{kW}$ DHW load in the morning was also shifted to later in the day. A potential for underheating exists when the demand responsive controls reduce the heating set point. Zone temperature fluctuations were reduced during the load-shedding period by not setting back the nighttime set point, which allows for increased heat storage in the building thermal capacitance during periods of low demand. Again, the equipment and lighting loads could not be shifted or limited because they are necessary for building operation. 


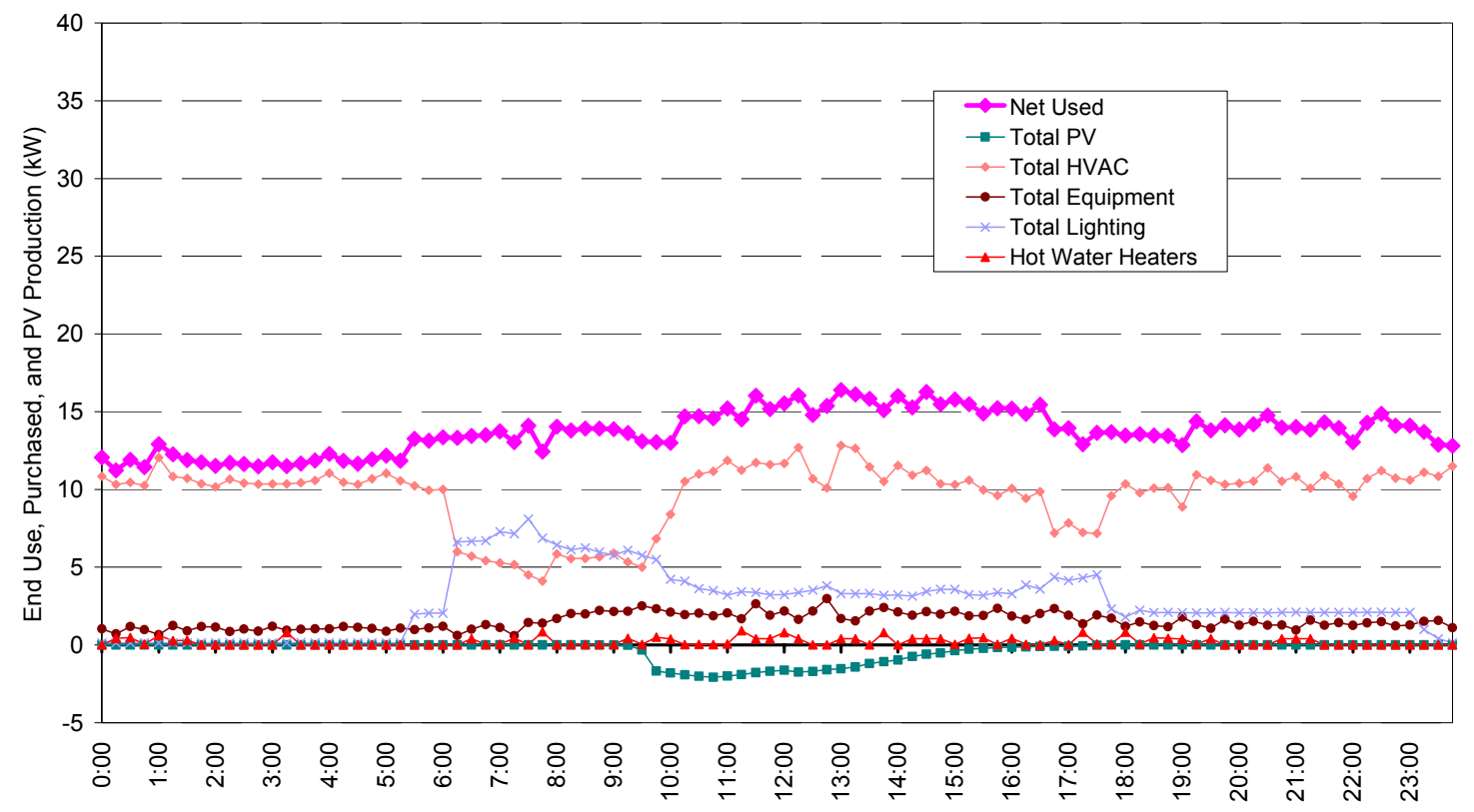

Figure 5-8 Typical heating profile with demand limiting controls, February 8, 2003

Figure 5-9 shows the differences of the average monthly winter site purchased electricity use over the winter of 2001-2002 (December 2001-March 2002) and the winter of 2002-2003 (December 2002March 2003). The graph shows that during the winter of 2001-2002, the building used much more energy with a higher average peak, whereas during the winter of 2002-2003, it used much less energy with a lower average peak. The average heating profile shows the strategy of demand limiting controls. On average, the BAS limits the consumption of the electric heating and the DHW systems in the morning (during typical peak lighting consumption) and shifts the heating load to the afternoon (when PV production and daylighting are available) and nights (during typical minimum site consumption). The average daily heating profile was higher in the winter of 2001-2002 because the occupant controlled set point was $2-4^{\circ} \mathrm{F}\left(1.1-2.2^{\circ} \mathrm{C}\right)$ higher than the winter of $2002-2003$. The domestic hot-water load without controls is lumped in the morning. With the controls, the recovery is spread throughout the day. 


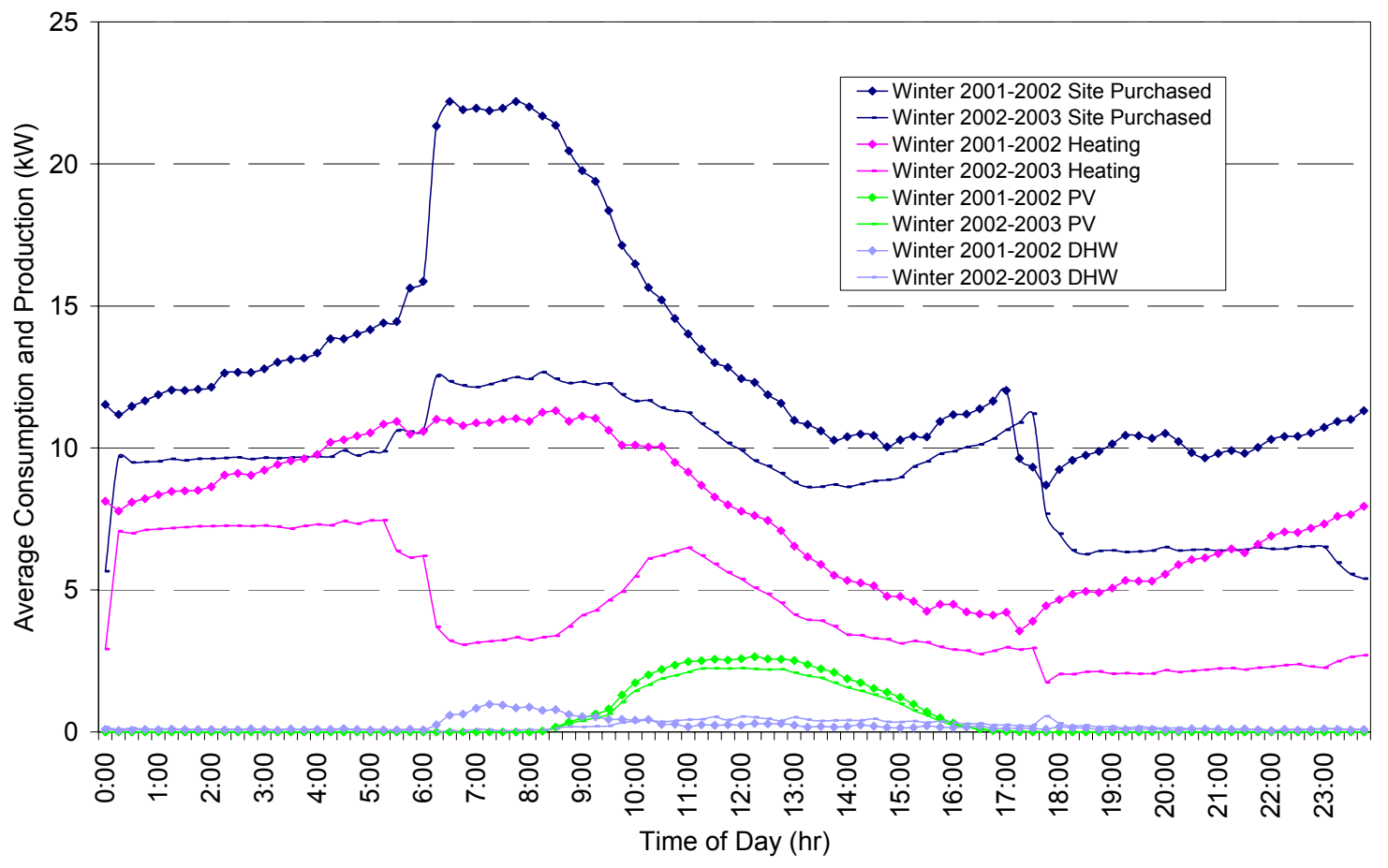

Figure 5-9 Average daily site energy purchased for heating, cooling, and hot water and PV production, Winter 2001-2002 compared to Winter 2002-2003

We computed the energy demand for each month from November 2001 through May 2003, as seen in Figure 5-10. Table 5-7 shows the number of hours the building was at certain power consumption ranges for each month from November 2001 through May 2003. The table also calculated the load fraction for the demand, which is defined as the average power consumption over the month divided by the peak demand over the month. We considered the demand controls effective if the load fraction was greater than $40 \%$, which occurred most of the time.

The demands typically occurred during the morning when the building was first occupied. In all the cases, the PV production during the time of peak demand was minimal (see Table 5-6); therefore, the PV could not help reduce the overall demand and related costs. 


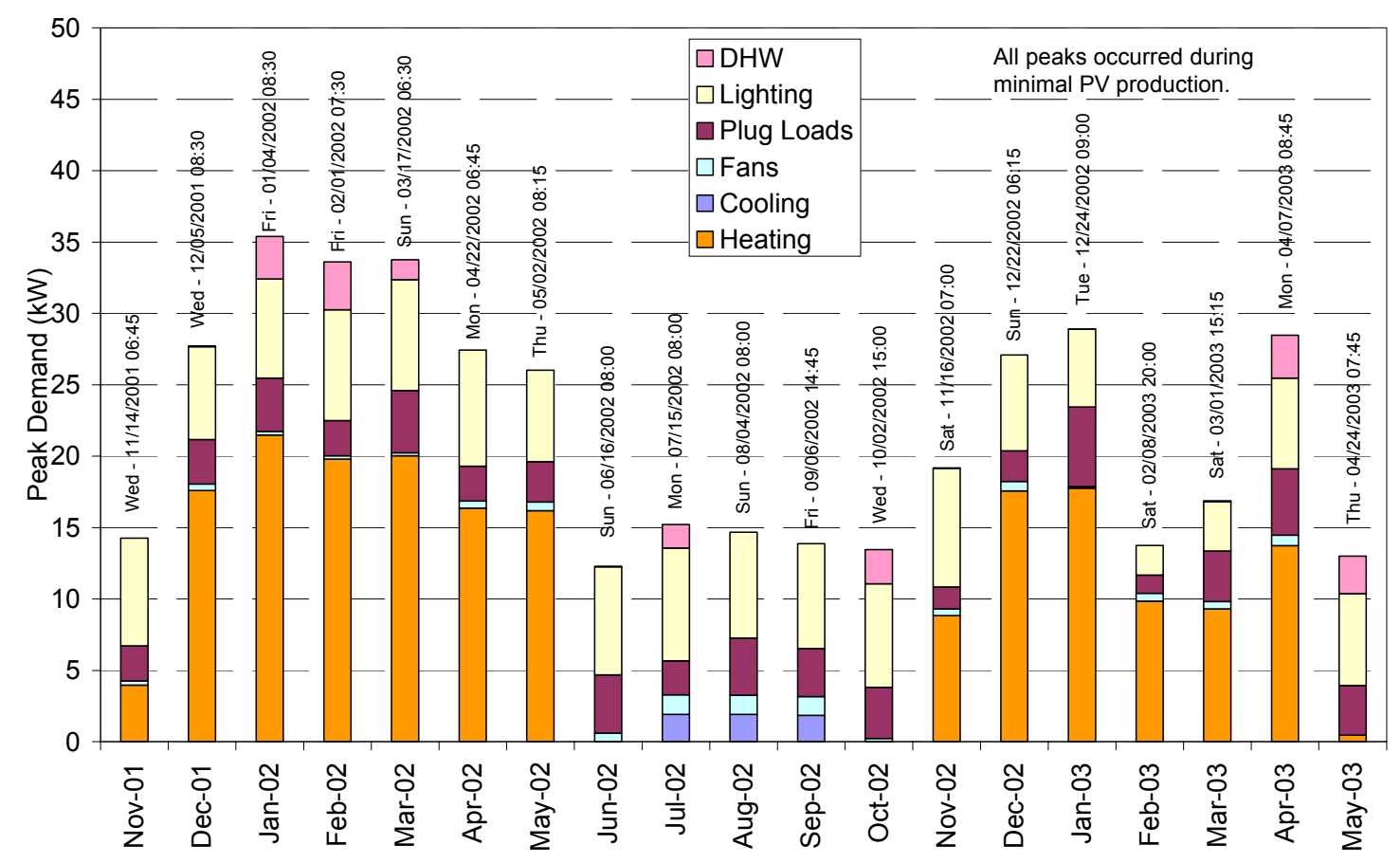

Figure 5-10 Visitor Center and Comfort Station peak demand analysis and time of occurrence for each month

Table 5-6 PV Contribution during Peak Demands

\begin{tabular}{|c|r|}
\hline Month & $\begin{array}{r}\text { PV } \\
(\text { W })\end{array}$ \\
\hline Nov-01 & 0 \\
\hline Dec-01 & 0 \\
\hline Jan-02 & 58 \\
\hline Feb-02 & 170 \\
\hline Mar-02 & 180 \\
\hline Apr-02 & 0 \\
\hline May-02 & 0 \\
\hline Jun-02 & 220 \\
\hline Jul-02 & 0 \\
\hline Aug-02 & 0 \\
\hline Sep-02 & 0 \\
\hline Oct-02 & 130 \\
\hline Nov-02 & 0 \\
\hline Dec-02 & 0 \\
\hline Jan-03 & 340 \\
\hline Feb-03 & 0 \\
\hline Mar-03 & 0 \\
\hline Apr-03 & 210 \\
\hline May-03 & 320 \\
\hline
\end{tabular}


Table 5-7 Information on Demand Occurrences and Reasonability

\begin{tabular}{|c|c|c|c|c|c|c|c|c|c|c|c|c|c|c|c|c|}
\hline \multirow[b]{2}{*}{ Month } & \multirow{2}{*}{$\begin{array}{c}\text { Peak } \\
\text { Demand } \\
(\mathbf{k W})^{1} \\
\end{array}$} & \multirow{2}{*}{$\begin{array}{l}\text { Time of Peak } \\
\text { Demand }\end{array}$} & \multicolumn{13}{|c|}{ Number of Hours at kW Demand } & \multirow[b]{2}{*}{ Load Fraction } \\
\hline & & & $<10$ & $\begin{array}{c}10 \text { to } \\
12 \\
\end{array}$ & \begin{tabular}{|c|}
12 to \\
14
\end{tabular} & \begin{tabular}{|c|}
14 to \\
16 \\
\end{tabular} & \begin{tabular}{|c|}
16 to \\
18
\end{tabular} & \begin{tabular}{|c|}
18 to \\
20
\end{tabular} & \begin{tabular}{|c|}
20 to \\
22 \\
\end{tabular} & $\begin{array}{c}22 \text { to } \\
24\end{array}$ & \begin{tabular}{|c|}
24 to \\
26 \\
\end{tabular} & \begin{tabular}{|c|}
26 to \\
28 \\
\end{tabular} & \begin{tabular}{|c|}
28 to \\
30
\end{tabular} & \begin{tabular}{|c|}
30 to \\
32 \\
\end{tabular} & $>32$ & \\
\hline Nov-01 & 14.6 & $11 / 14 / 20016: 45$ & 532 & 89 & 12 & 3 & & & & & & & & & & $45.3 \%$ \\
\hline Dec-01 & 28.8 & $12 / 5 / 20018: 30$ & 324 & 11 & 10 & 22 & 30 & 118 & 77 & 48 & 46 & 34 & 4 & & & $46.7 \%$ \\
\hline Jan-02 & 36.1 & $1 / 4 / 20028: 30$ & 98 & 14 & 14 & 67 & 179 & 230 & 58 & 6 & 5 & 18 & 1 & & 1 & $45.3 \%$ \\
\hline Feb-02 & 33.4 & 2/1/2002 7:30 & 253 & 9 & 6 & 11 & 132 & 128 & 44 & 13 & 23 & 19 & 9 & 6 & 1 & $40.3 \%$ \\
\hline Mar-02 & 34.4 & $3 / 17 / 20026: 30$ & 377 & 7 & 9 & 16 & 110 & 34 & 22 & 24 & 24 & 19 & 4 & 3 & 1 & $30.0 \%$ \\
\hline Apr-02 & 27.5 & 4/22/2002 6:45 & 588 & 56 & 13 & 3 & 7 & 14 & 9 & 7 & 10 & 5 & & & & $24.1 \%$ \\
\hline May-02 & 26.1 & $5 / 2 / 20028: 15$ & 587 & 48 & 7 & 1 & 1 & 2 & 1 & 2 & 1 & 1 & & & & $22.9 \%$ \\
\hline Jun-02 & 12.1 & $6 / 16 / 20028: 00$ & 609 & 89 & 1 & & & & & & & & & & & $55.5 \%$ \\
\hline Jul-02 & 15.0 & $7 / 15 / 20028: 00$ & 553 & 117 & 55 & 15 & & & & & & & & & & $48.7 \%$ \\
\hline Aug-02 & 15.1 & $8 / 4 / 20028: 00$ & 514 & 113 & 83 & 13 & & & & & & & & & & $52.6 \%$ \\
\hline Sep-02 & 14.1 & 9/6/2002 14:45 & 555 & 133 & 58 & 1 & & & & & & & & & & $53.2 \%$ \\
\hline Oct-02 & 15.3 & $10 / 2 / 2002$ 15:00 & 393 & 267 & 34 & 4 & & & & & & & & & & $54.5 \%$ \\
\hline Nov-02 & 18.6 & 11/16/2002 7:00 & 426 & 243 & 23 & 7 & 8 & 3 & & & & & & & & $46.7 \%$ \\
\hline Dec-02 & 27.1 & 12/22/2002 6:15 & 434 & 53 & 18 & 23 & 11 & 19 & 14 & 12 & 4 & 2 & & & & $32.3 \%$ \\
\hline Jan-03 & 27.9 & 12/24/2002 9:00 & 296 & 107 & 41 & 49 & 69 & 53 & 26 & 20 & 12 & 4 & & & & $40.4 \%$ \\
\hline Feb-03 & 15.2 & 2/8/2003 20:00 & 423 & 152 & 46 & 30 & & & & & & & & & & $54.5 \%$ \\
\hline Mar-03 & 17.4 & $3 / 1 / 2003$ 15:15 & 310 & 120 & 141 & 52 & 21 & & & & & & & & & $54.1 \%$ \\
\hline Apr-03 & 29.3 & 4/7/2003 8:45 & 629 & 90 & 56 & 16 & 8 & 2 & 1 & 1 & 1 & & 1 & & & $23.7 \%$ \\
\hline May-03 & 14.6 & 4/24/2003 7:45 & 546 & 89 & 8 & 2 & & & & & & & & & & $46.6 \%$ \\
\hline
\end{tabular}


Although the demand responsive controls typically worked, all that is required for a peak demand charge is a 15-minute window when the controls fail to limit the demand. During 2003, the demand was slightly lower overall, with several months much lower. During the swing season in 2002 (March through May), the load fractions were low, which denotes poor controls. During the same period for 2003, the load fractions were reasonable. The controls strategies changed by continually monitoring the power consumption in the building and preventing new peaks unless necessary.

For the months of December 2002 and January 2003, the controls worked overall, as is shown by the average load profile in Figure 5-9, but failed a few times, resulting in high demand charges. Reasons for this failure are partially due to problems with BAS implementing the controls. Demand responsive software was difficult to implement due to limited BAS programming flexibility. A BAS system failure occurred during the month of April 2003 and variables were reset to defaults. As a result, the demand for April 2003 was much higher because all the controls for limiting DHW and heating were unavailable during the failure period.

The peak demand in April 2003 was a result of BAS operation without any demand responsive control. The evaluators expect the peak demands for February and March 2003 without demand responsive controls would have been similar to, if not greater than, the $29-\mathrm{kW}$ peak demand of April 2003. This suggests that the demand responsive controls reduced the peak demands in February and March 2003 by at least 38\%.

In general, by identifying short-term, nonessential end uses that contribute to peak demand charges, we developed a control strategy to shift these loads to significantly reduce demand charges. Understanding the optimal demand controls involves studying precooling/preheating techniques to charge the thermal mass of the building during off-peak hours. Using forecasted weather could potentially increase the demand savings by optimizing the nighttime setup/setback control strategies. For the ZNP case, a stable BAS and control strategy are necessary to realize these potential savings. It is essential that demand management systems be robust to prevent unnecessary utility charges. Analysis of peak demands at ZNP over the last two winters has shown that a $38 \%$ peak demand reduction is possible with successful demand responsive controls. If the demand responsive controls had been successful at shifting the demand for the entire winter of 2002-2003, the annual demand costs would have been reduced an additional $\$ 350$, or $18 \%$ of the total demand charges. Although it is straightforward to estimate potential demand savings due to responsive controls, a variable time step, whole-building simulation (including PV simulation capabilities) is needed to determine the site consumption costs associated with demand responsive control strategies. Table 5.7 shows where there is room for improvement. Months with only a few hours at the peak demand indicate that additional peak shedding is possible.

\subsection{Development of Energy Models}

The whole-building evaluation also includes modeling conventional buildings to calculate energy savings for typical weather years. A conventional building, or base case, was modeled to provide an energy benchmark. The base case was simulated using measured weather, and then compared to measured site use, source use, and utility bills. Performance indicators analyzed include site energy savings, source energy savings, and site cost energy savings. The flow chart in Figure 5-11 shows how the measured data was used in the models and the process used to obtain the simulation results. 


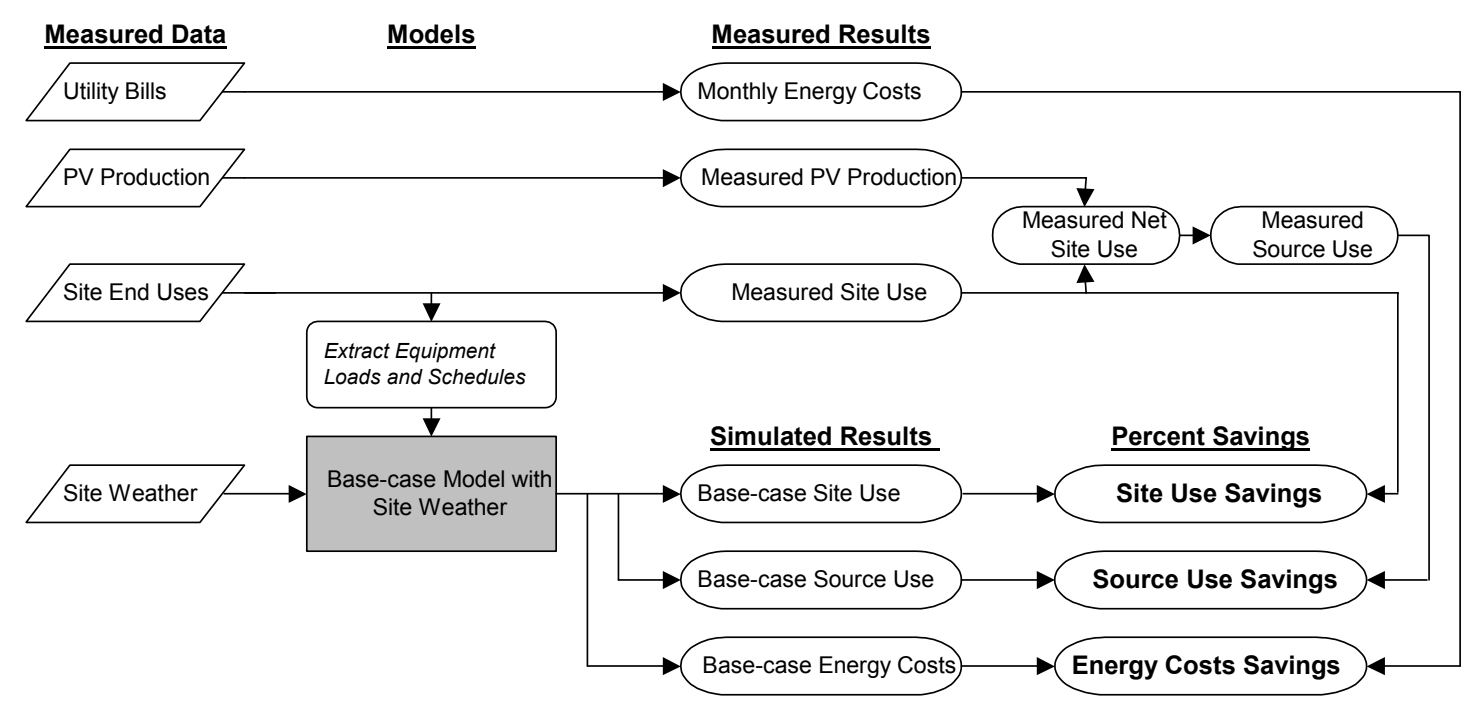

Figure 5-11 Whole-building evaluation flowchart: as-built building and base-case model

\subsubsection{DOE-2 Building Simulation Tool}

DOE-2 is a whole-building simulation program that can calculate hourly building heating and cooling loads, simulate the operation of primary and secondary HVAC systems, calculate lighting and equipment consumption, and perform economic analysis (Winkelmann et al. 1993). The primary inputs required for DOE-2 to calculate the design and hourly space loads include building location and weather files; constructions for fenestration, walls, roof, and floors; the geometry, size and orientation of the building; and internal loads such as occupancy, lighting, and equipment. Characteristics, configurations, and controls of the HVAC components for the primary HVAC systems make up the input. The outputs from the simulation include a large list of hourly, monthly, and annual verification and summary reports. The validity and consistency of DOE-2 has been extensively researched and reported (Pasqualetto 1997).

\subsubsection{Development of the Base-Case Model}

Computer simulations were used to help design the building and provide a base-case benchmark to measure energy savings. We modeled the initial base case based on the proposed design as discussed in Section 3.2.6. As previously discussed and shown in Table 4-1, the as-built design differed from the initial proposed design. To provide a better comparison for evaluating energy savings, the evaluators reworked the base-case DOE-2 model derived from as-built characteristics.

The second base-case model included the initial base-case characteristics as described in Table 3-1 with updated as-built characteristics. We modeled the new base-case floor area with an $11,726-\mathrm{ft}^{2}\left(1,089-\mathrm{m}^{2}\right)$ square floor plan with solar neutral fenestration. The proposed base-case model only included the Visitor Center, while the new base-case model included the Visitor Center and the Comfort Station. The new base-case model will be referred to as the base-case model for the remainder of the document. We modeled the base-case heating and cooling systems with an electric air-source heat pump and supplemental electric resistive heat instead of a propane furnace to be consistent with the fuel that was actually approved for availability at the site. We modeled the heating and cooling efficiencies with a COP of 2.0 for heating mode and a COP of 3.0 for cooling mode (as specified by 10 CFR 435 and ASHRAE 90.1-1989). We modeled heating and cooling set points based on the actual set points. The lighting power densities were modeled as $2.2 \mathrm{~W} / \mathrm{ft}^{2}\left(24 \mathrm{~W} / \mathrm{m}^{2}\right)$ in the retail and display zones $(16.1 \mathrm{~kW}$ total), $1.4\left(15 \mathrm{~W} / \mathrm{m}^{2}\right)$ in the office zones $(2.2 \mathrm{~kW}$ total $)$, and $1.0\left(11 \mathrm{~W} / \mathrm{m}^{2}\right)$ for the restroom zones $(2.7 \mathrm{~kW}$ 
total). For this model, the lights are assumed to be on during occupied hours, as no daylighting or occupancy sensors are included in the base case. We modeled occupied hours based on the occupancy schedule of 6 a.m. to 7 p.m. in the summer and 6 a.m. to 5 p.m. in the winter.

To calculate energy costs, the actual utility rate structure was applied to the base-case model. The modeled utility rate structure included a consumption charge of $\$ .0277 / \mathrm{kWh}$, a monthly demand charge of $\$ 8.1 / \mathrm{kW}$, a $\$ 15.00$ fixed monthly charge, and a small variable rate adjustment charge.

Table 5-8 As-Built Design and Base-Case Comparisons

\begin{tabular}{|c|c|c|}
\hline Item & Base-Case Model & As-Built Building \\
\hline Size $-\mathrm{ft}^{2}\left(m^{2}\right)$ & $11,726(1089.4)$ & $11,726(1089.4)$ \\
\hline Heating System & Electric Heat Pump & $\begin{array}{l}\text { Electric Radiant Panels and } \\
\text { Trombe Wall }\end{array}$ \\
\hline Wall R-Value $-\mathrm{ft}^{2} \cdot{ }^{\circ} \mathrm{F} \cdot \mathrm{hr} / \mathrm{Btu}\left(m^{2} \cdot \mathrm{K} / W\right)$ & $13.9(2.45)$ & 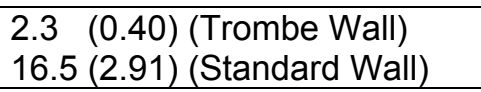 \\
\hline Window R-Value $-\mathrm{ft}^{2} \cdot{ }^{\circ} \mathrm{F} \cdot \mathrm{hr} / \mathrm{Btu}\left(\mathrm{m}^{2} \cdot \mathrm{K} / \mathrm{W}\right)$ & $1.73(0.30)$ & $\begin{array}{l}2.3 \text { (0.41) (South and East) } \\
3.85(0.678) \text { (North and West) }\end{array}$ \\
\hline Window to Wall Area & $28 \%$ & $28 \%$ \\
\hline $\begin{array}{l}\text { Floor Perimeter Insulation (48 in vertical } \\
\text { foundation insulation) R-Value }-\mathrm{ft}^{2} \cdot{ }^{\circ} \mathrm{F} \cdot \mathrm{hr} / \mathrm{Btu} \\
\left(\mathrm{m}^{2} \cdot \mathrm{KW}\right)\end{array}$ & $4(0.7)$ & $11.3(1.99)$ \\
\hline Roof R-Value - $\mathrm{ft}^{2} \cdot{ }^{\circ} \mathrm{F} \cdot \mathrm{hr} / \mathrm{Btu}\left(\mathrm{m}^{2} \cdot \mathrm{K} W\right)$ & $22.7(4.00)$ & $30.9(5.44)$ \\
\hline Infiltration $(\mathrm{ACH})$ & 0.3 & Unknown (Not Measured) \\
\hline Equipment Load - W/ft ${ }^{2}\left(W / m^{2}\right)$ & $0.75(0.13)$ & $0.75(0.13)$ \\
\hline Daylighting & No & $\begin{array}{l}\text { Yes, clerestories; photo } \\
\text { sensors controls }\end{array}$ \\
\hline Overhangs & No & Yes \\
\hline Demand Limiting Controls & No & Yes \\
\hline \multicolumn{3}{|l|}{ Lighting Levels $\mathrm{W} / \mathrm{ft}^{2}\left(\mathrm{~W} / \mathrm{m}^{2}\right)$} \\
\hline Office Space & $1.4(15)$ & $0.96(10)$ \\
\hline Retail and Display Space & $2.2(24)$ & $0.90(9.7)$ \\
\hline Restrooms & $1.0(11)$ & $1.0(11)$ \\
\hline Outdoor and Parking Lot (W) & 400 & 400 \\
\hline
\end{tabular}

Ideally, the base-case site energy use, source energy use, and energy costs would be compared to an asbuilt model to calculate savings for a typical weather year. In this case, an as-built model of the Zion Visitor Center and Comfort Station was beyond the scope of this analysis due to limitations in the wholebuilding simulation tools. These limitations include nonexistent building integrated modeling techniques for the energy use and cooling capacity of cooltowers, difficulties modeling the as-built operation of subhourly demand limiting controls with integrated PV production, and uncertainties with Trombe wall thermal models. We attempted to account for the inherent uncertainty involved in comparing measured data to a simulation by calibrating the base-case model with measured weather data, measured equipment loads, and operation schedules. We calibrated the base-case model with measured weather data from November 2001 through October 2002. This modeling procedure accounted for the actual weather conditions in the prediction of base-case performance, allowing for a better comparison of the measured energy performance over this simulation period. Actual equipment loads and operation schedules were extracted from the measured data and modeled in the calibrated base-case as well. 


\subsection{Whole-Building Energy Performance Results}

Whole-building evaluation results included in this section are energy cost savings, site energy savings, and source energy savings. Further results presented in Section 6 include Trombe wall performance, cooling tower performance, comfort levels, daylighting and lighting results, and PV system performance. Evaluation of these issues outline explicit mistakes made during the application of the 10-step low-energy design process and the consequential affects that detracted from measured energy performance.

\subsubsection{Energy Cost Analysis}

The Visitor Center Complex was designed to minimize purchased energy costs; therefore, this is the primary energy performance metric considered. The monthly energy costs are shown in Table 5-9 and Figure 5-12. The total monthly energy costs were obtained from the utility bills and the data shown in Table 5-9 were derived from these monthly bills. The monthly utility billing cycle did not start on the first of the month and end on the last of the month. Monthly data shown in Table 5-9 and Figure 5-12 are represented by the month in which the majority of the data is contained. Included in the monthly energy costs are demand charges based on the monthly peak consumption over a 15-minute interval, a consumption charge based on the total electricity consumed over the month, and taxes and fixed charges. The utility rate structure, based on electrical utility bills from Utah Power, includes an energy charge of $\$ 0.0277 / \mathrm{kWh}$, a demand charge of $\$ 8.1 / \mathrm{kW}$, and a $\$ 15.00$ fixed charge with a variable rate adjustment charge. From June 2002 through May 2003, the annual utility costs were $\$ 4,383$ or $\$ 0.37 / \mathrm{ft}^{2}\left(\$ 3.98 / \mathrm{m}^{2}\right)$ based on $11,726 \mathrm{ft}^{2}\left(1089.4 \mathrm{~m}^{2}\right)$ of gross floor area. The energy cost intensity from November 2001 through October 2002 was $\$ 0.43 / \mathrm{ft}^{2}\left(\$ 4.63 / \mathrm{m}^{2}\right)$. Compared to the energy cost performance of other highperformance commercial buildings, ENERGY STAR buildings, and the top CBECS buildings documented in Section 2, the energy cost intensity of the Visitor Center Complex is significantly better.

Table 5-9 Visitor Center Complex Energy Costs, Nov. 2001 through May 2003

\begin{tabular}{|c|c|c|c|c|c|c|}
\hline & $\begin{array}{l}\text { Demand } \\
\text { Cost }\end{array}$ & $\begin{array}{l}\text { Consumption } \\
\text { Cost }\end{array}$ & $\begin{array}{l}\text { Taxes/Fixed } \\
\text { Costs }\end{array}$ & $\begin{array}{l}\text { Total } \\
\text { Costs } \\
\end{array}$ & & \\
\hline Nov-01 & $\$ 122$ & $\$ 129$ & $\$ 27$ & $\$ 277$ & & \\
\hline Dec-01 & $\$ 243$ & $\$ 290$ & $\$ 34$ & $\$ 566$ & & \\
\hline Jan-02 & $\$ 308$ & $\$ 357$ & $\$ 37$ & $\$ 702$ & & \\
\hline Feb-02 & $\$ 300$ & $\$ 292$ & $\$ 35$ & $\$ 627$ & & \\
\hline Mar-02 & $\$ 300$ & $\$ 187$ & $\$ 33$ & $\$ 520$ & & \\
\hline Apr-02 & $\$ 235$ & $\$ 150$ & $\$ 30$ & $\$ 415$ & & \\
\hline May-02 & $\$ 204$ & $\$ 112$ & $\$ 29$ & $\$ 345$ & & \\
\hline Jun-02 & $\$ 105$ & $\$ 148$ & $\$ 29$ & $\$ 282$ & & \\
\hline Jul-02 & $\$ 146$ & $\$ 179$ & $\$ 32$ & $\$ 356$ & \multirow{3}{*}{$\begin{array}{c}\text { Running } \\
\text { Annual } \\
\text { Total }\end{array}$} & \multirow{3}{*}{$\begin{array}{c}\text { Cost } \\
\text { Intensity } \\
\$ / \mathrm{ft}^{2} \\
\left(\$ / \mathrm{m}^{2}\right)\end{array}$} \\
\hline Aug-02 & $\$ 138$ & $\$ 171$ & $\$ 31$ & $\$ 340$ & & \\
\hline Sep-02 & $\$ 122$ & $\$ 165$ & $\$ 31$ & $\$ 317$ & & \\
\hline Oct-02 & $\$ 138$ & $\$ 177$ & $\$ 32$ & $\$ 347$ & \$5,094 & $0.43(4.6)$ \\
\hline Nov-02 & $\$ 162$ & $\$ 185$ & $\$ 33$ & $\$ 380$ & $\$ 5,197$ & $0.43(4.6)$ \\
\hline Dec-02 & $\$ 284$ & $\$ 187$ & $\$ 37$ & $\$ 508$ & $\$ 5,139$ & $0.44(4.7)$ \\
\hline Jan-03 & $\$ 243$ & $\$ 246$ & $\$ 38$ & $\$ 527$ & $\$ 4,964$ & $0.42(4.5)$ \\
\hline Feb-03 & $\$ 130$ & $\$ 160$ & $\$ 31$ & $\$ 320$ & $\$ 4,658$ & $0.40(4.3)$ \\
\hline Mar-03 & $\$ 154$ & $\$ 190$ & $\$ 35$ & $\$ 378$ & $\$ 4,516$ & $0.39(4.2)$ \\
\hline Apr-03 & $\$ 219$ & $\$ 124$ & $\$ 26$ & $\$ 368$ & $\$ 4,470$ & $0.38(4.1)$ \\
\hline May-03 & $\$ 113$ & $\$ 121$ & $\$ 25$ & $\$ 259$ & $\$ 4,383$ & $0.37(4.0)$ \\
\hline
\end{tabular}




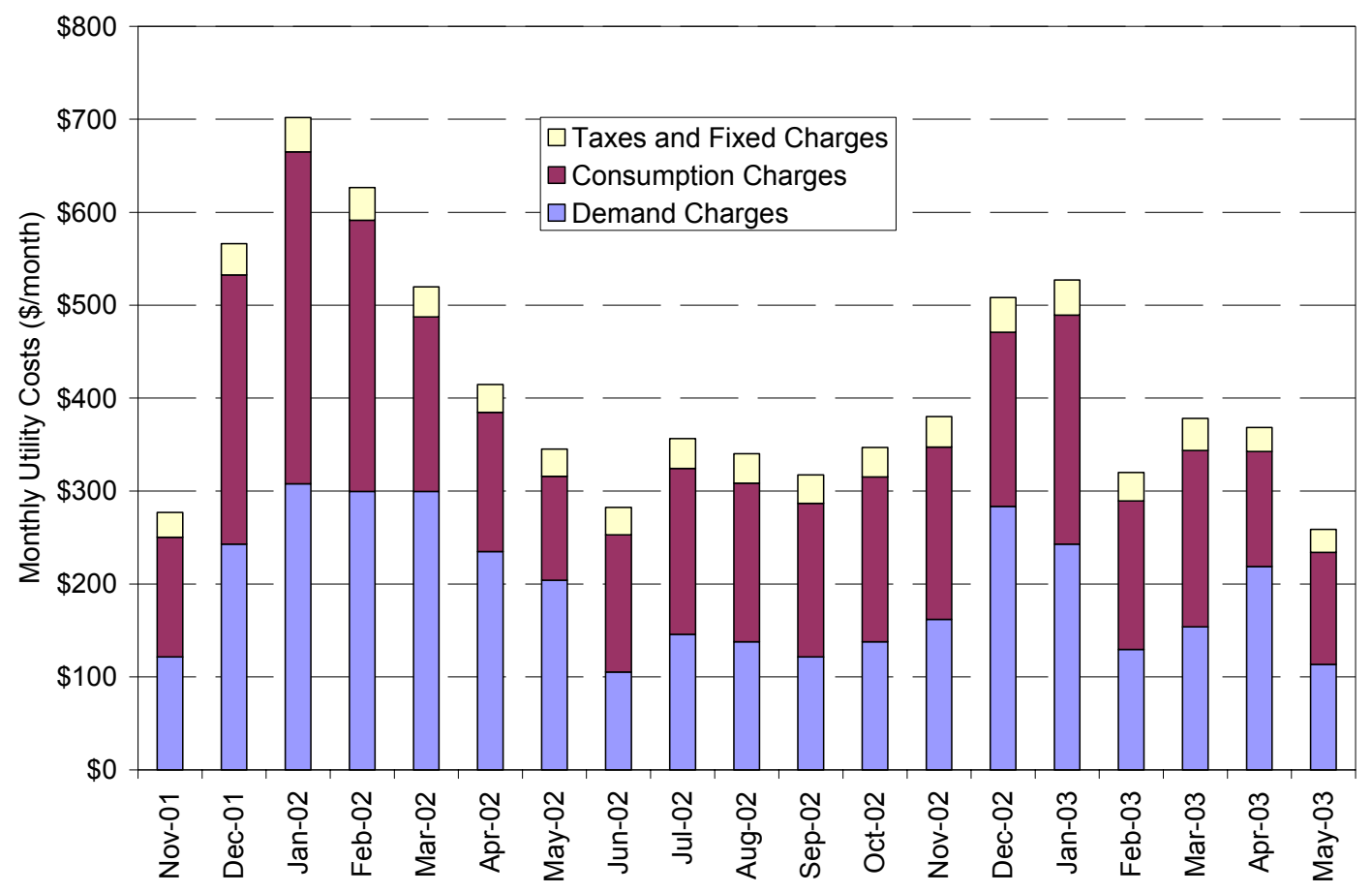

Figure 5-12 Visitor Center Complex energy costs, Nov. 2001 through May 2003

The initial prediction of cost savings was $80 \%$ compared to a $7,600-\mathrm{ft}^{2}\left(706-\mathrm{m}^{2}\right)$ base case. Using a basecase model simulated with measured weather data from November 2001 through October 2002, the energy cost savings were 67\%. From November 2001 through October 2002, the measured energy cost intensity was $\$ 0.43 / \mathrm{ft}^{2}\left(\$ 4.63 / \mathrm{m}^{2}\right)$ or an annual cost of $\$ 5,094$, while the simulated base-case model was $\$ 1.30 / \mathrm{ft}^{2}\left(\$ 13.99 / \mathrm{m}^{2}\right)$ or an annual cost of $\$ 15,250$. A monthly energy cost comparison to the base-case including demand charges, consumption charges, and taxes is shown in Figure 5-13.

The reason the energy cost savings are less than the expected $80 \%$ savings is because of the differences between the as-built building and proposed design used to determine the expected savings levels. A significant difference between the as-built and proposed design was the daylighting system. In the proposed design, the design team expected daylighting to provide almost all of the necessary daytime lighting to the Visitor Center and Comfort Station. This is not the case in the as-built design. The size of the specified clerestory visible glazing is not what was installed due to differences in the window specifications and actual design. The frames, mullions, screens, and automation mechanisms all reduced the amount of visible glazing in the clerestory windows, but also reduced the expected daylighting provided by the clerestories from the original design. Additionally, the dark structural beams throughout the buildings were not considered when the daylighting features were designed. These dark beams absorb and block significant portions of the clerestory daylighting. Finally, the ceiling installed was a lowreflective whitewashed board, rather than a high-reflective white as suggested. The color problems were identified during construction based on the proposed colors of the wood and the ceiling. During design, we recommended high-reflective white ceiling surfaces.

When combined, these daylighting design issues reduced the expected daylighting contribution and resulted in increased lighting consumption and energy costs, as daylighting was not able to meet the entire daytime lighting load. Lighting was responsible for $31 \%$ of the annual site energy consumption, as shown previously in Figure 5-6 and discussed further in Section 6.3.2. 
Another difference between the proposed and as-built design was the heating systems. The as-built heating system includes electric radiant heating panels, while the proposed design included a propane furnace. During the redesign/design development step of the low-energy design process, the designers decided to use electric radiant heating panels instead of propane. The consumptive cost of electricity was similar to the cost of propane. A cost comparison between an electric and a propane heating system estimated that the electric system would be more cost effective if it did not create an additional demand charge on the building. As shown in Figure 5-10, this is not the case. The heating system was often responsible for significant demand charges, which prevented lower measured energy cost savings. This problem is still being studied as an area of possible improvement.

The base case was an all-electric building that used air-source heat pumps, as specified in ASHRAE 90.1. Comparing energy consumption of an electric resistive heating system to a more efficient heat pump system resulted in a lower energy cost saving as well. Although the energy cost saving was less than expected at $67 \%$, the realized cost saving is still significant. Again, if the redesign had been resimulated during the design process, the expected energy cost saving would have been recalculated. These energy cost savings would have been closer to the realized savings.

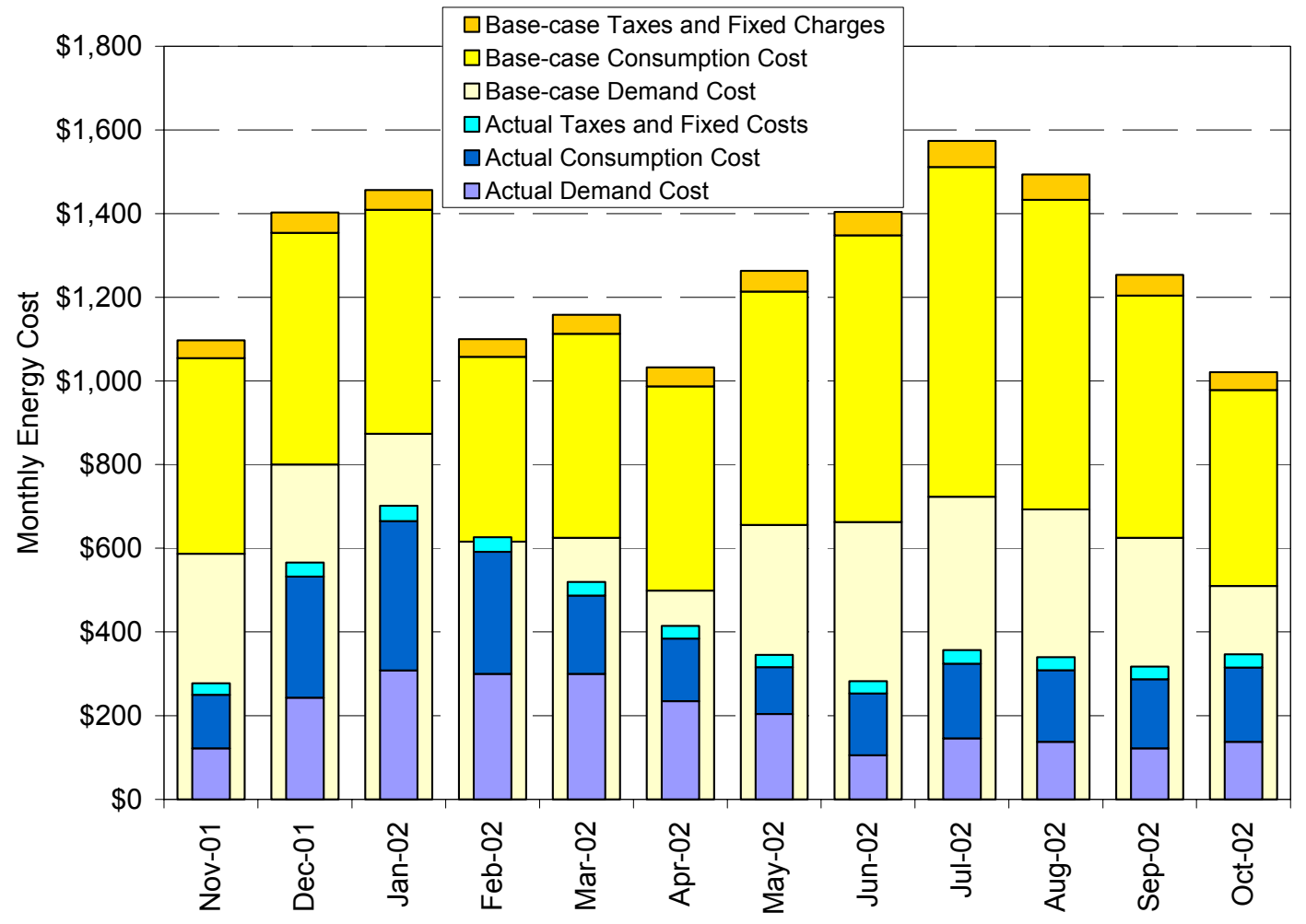

Figure 5-13 Base-case and energy costs, November 2001 through October 2002

As shown in Figure 5-13, the largest monthly cost savings occur during the summer months. The basecase, heat-pump cooling system uses significantly more energy with higher demand costs than the as-built cooltowers. The significant demand cost during the winter of 2001-2002 point to the importance of understanding what causes peak demands and if the peak demand is controllable. This offers the most potential in optimizing energy costs. 


\subsubsection{Site Analysis}

The simulated energy use of the base-case model, as developed in Section 5.3.2 using a measured weather file, is $241,706 \mathrm{kWh} / \mathrm{yr}$, at a site energy use intensity of $70.3 \mathrm{kBtu} / \mathrm{ft}^{2} \cdot \mathrm{yr}\left(798 \mathrm{MJ} / \mathrm{m}^{2} \cdot \mathrm{yr}\right)$. The monthly energy use comparison between the base-case model and the Visitor Center Complex is shown in Figure 5-14 with corresponding data in Table 5-10. The annual site energy savings from November 2001 through October 2002 are $62 \%$, not including PV. The peak energy consumption has been shifted from the summer to the winter in an area where electrical peaks occur in the summer. Although not quantifiable, this reduces the impact on the development to the utility grid.

The cooling savings are $59,514 \mathrm{kWh}$. The cooltower pumps consume $93 \%$ less energy than the base-case air-source heat pumps ${ }^{3}$. The downdraft cooltower air delivery mechanism and radiant heating panels also reduce fan consumption. Further analysis of the cooling system is included in Section 6.4.2. Significant savings are realized due to daylighting and lighting systems. The expected annual lighting savings are $78,824 \mathrm{kWh}$. Further analysis of daylighting and lighting savings are included in Section 6.4.4. The heating system used more electricity than the base case because the efficiency of the electrical radiant system is $100 \%$, while the base-case heat pumps were modeled with a COP of 3.0. Additional heating was required to make up for the lighting systems, as these more efficient lights provide less heat to the building than do the lights used in the base case. The increased heating energy use in the as-built Visitor Center Complex, due to the electric heating systems and efficient lighting systems, counteracts any energy savings due to Trombe wall gains and the high-performance envelope.

No equipment or DHW savings are expected because these loads are dependent on occupancy and installed capacity. The base-case loads represent as-built equipment power densities and operational schedules.

Table 5-10 Base-Case and Measured Site Annual Consumption and Savings

\begin{tabular}{|l|c|c|c||c|}
\hline & $\begin{array}{c}\text { Base-Case Site } \\
\text { Annual } \\
\text { Consumption }(\mathrm{kWh})\end{array}$ & $\begin{array}{c}\text { Measured Site } \\
\text { Annual } \\
\text { Consumption }(\mathrm{kWh})\end{array}$ & $\begin{array}{c}\text { Site Annual } \\
\text { Savings } \\
(\mathrm{kWh})\end{array}$ & $\begin{array}{c}\text { Site Annual } \\
\text { Savings } \\
(\%)\end{array}$ \\
\hline \hline Heating & 20,608 & 24,571 & $-3,963$ & $-19 \%$ \\
\hline Cooling & 63,915 & 4,401 & 59,514 & $93 \%$ \\
\hline Fans & 19,190 & 4,743 & 14,447 & $75 \%$ \\
\hline Lighting & 107,781 & 28,957 & 78,824 & $73 \%$ \\
\hline Equipment/Other & 26,769 & 26,769 & 0 & $0 \%$ \\
\hline $\begin{array}{l}\text { Domestic Hot } \\
\text { Water }\end{array}$ & 3,443 & 3,435 & 8 & $0 \%$ \\
\hline \hline $\begin{array}{l}\text { Total Complex } \\
\text { Consumption }\end{array}$ & 241,706 & 92,876 & 148,830 & $62 \%$ \\
\hline
\end{tabular}

\footnotetext{
${ }^{3}$ The embodied energy in evaporating the water was not considered important because the water supply is gravity fed from the river and treated in the park.
} 


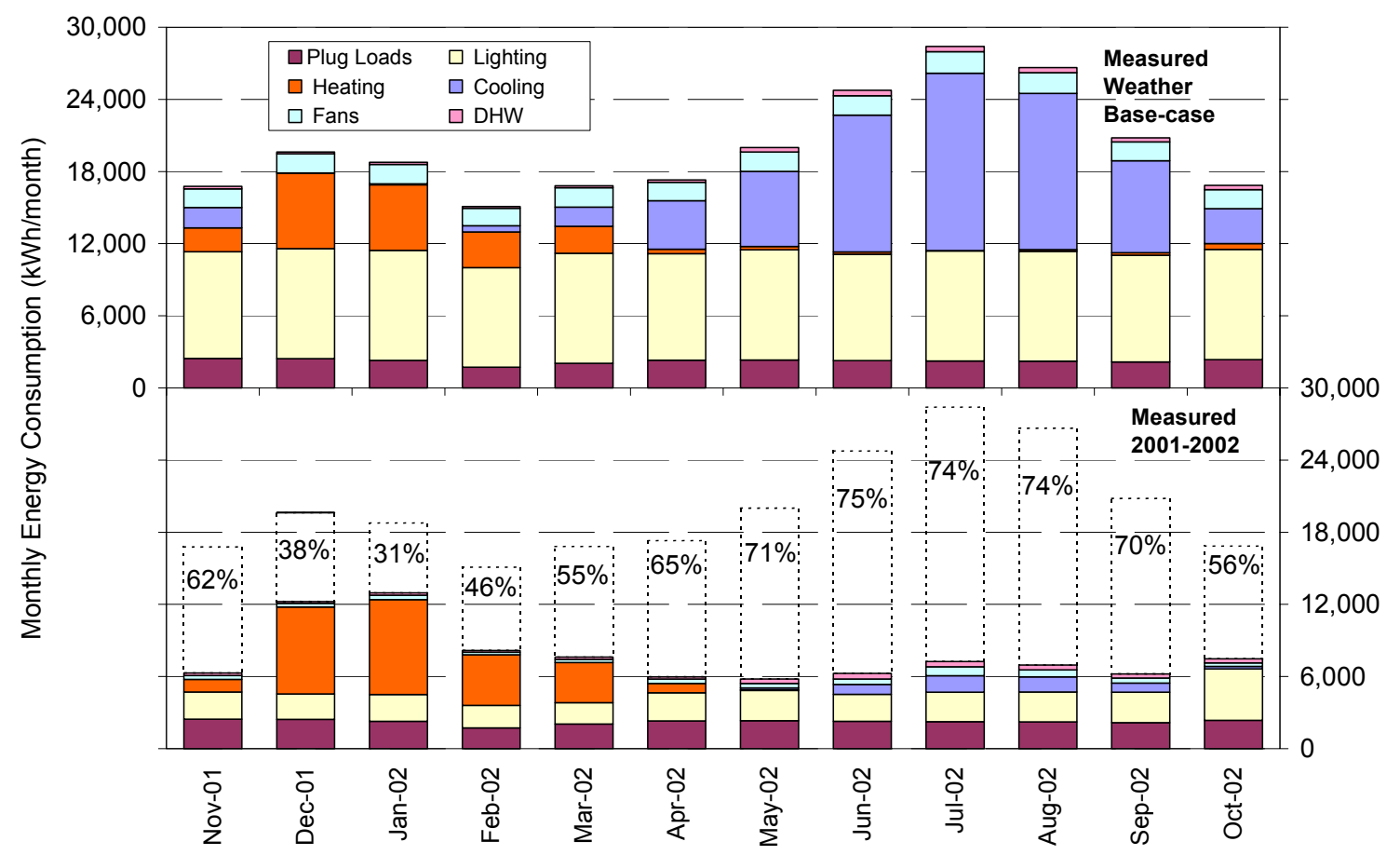

Figure 5-14 Base-case energy consumption compared to measured consumption

\subsubsection{Source Energy Analysis}

Source energy is the sum of the energy directly consumed at the site and the energy consumed by producing and delivering energy products. It represents the total energy required to deliver energy to a building. Documenting source energy consumption is useful when emissions from energy sources are a concern. We calculated the base-case source energy and measured source energy consumption based on $31 \%$ electricity conversion and delivery efficiency from source to site. The electrical source-to-site efficiency was based on the conversion and distribution efficiency averaged over all sources of electricity generation in the nation, as specified by EIA's Annual Energy Review (EIA 2000). With measured weather data, the all-electric base-case building (described in Section 5.1.3) was predicted to consume $779,697 \mathrm{kWh}$ of source electricity. At $11,726 \mathrm{ft}^{2}\left(1,089.4 \mathrm{~m}^{2}\right)$, the annual base-case source energy consumption intensity was $227 \mathrm{kBtu} / \mathrm{ft}^{2} \cdot \mathrm{yr}\left(2,580 \mathrm{MJ} / \mathrm{m}^{2} \cdot \mathrm{yr}\right)$. Recall that the base-case building has a heat-pump as the HVAC system.

A primary consideration in the source energy consumption calculation was the electricity that the PV system produced on site. This on-site electricity generation offsets the consumption of site electricity and the corresponding conversion and transmission losses. Therefore, the net energy consumption (total consumption minus PV production) was used to calculate the total source energy required to meet Zion's site electricity load.

From November 2001 through October 2002, the measured net site energy consumption was 85,016 kWh, or $24.7 \mathrm{kBtu} / \mathrm{ft}^{2} \cdot \mathrm{yr}\left(281 \mathrm{MJ} / \mathrm{m}^{2} \cdot \mathrm{yr}\right)$. At $31 \%$ source-to-site electricity conversion efficiency, the source energy consumption intensity was calculated to be $80 \mathrm{kBtu} / \mathrm{ft}^{2} \cdot \mathrm{yr}\left(909 \mathrm{MJ} / \mathrm{m}^{2} \cdot \mathrm{yr}\right)$, which is a source energy consumption savings of $65 \%$ as compared to the all-electric base-case source energy consumption. Compared to the top CBECS buildings, the Visitor Center Complex source energy intensity was 30\% less. 
NREL also calculated emissions reductions based on source energy consumption for the measured consumption and the base case. We calculated electricity emissions based on the data given in Table 5-11, which summarizes emissions for electricity generated by coal at a local power plant (EPA, 2003).

Table 5-11 Electricity Generation Emissions from Coal

\begin{tabular}{|l|c|}
\hline \multicolumn{1}{|c|}{ Emissions } & $\begin{array}{c}\text { Emissions Amount per Unit of } \\
\text { Electricity Generated } \\
\text { lb/kWh }(\mathrm{kg} / \mathrm{kWh})\end{array}$ \\
\hline $\mathrm{CO}_{2}$ (carbon dioxide) & $2.1(0.95)$ \\
\hline $\mathrm{SO}_{2}$ (sulfur dioxide) & $0.001(0.0005)$ \\
\hline $\mathrm{NO}_{\mathrm{X}}$ (oxides of nitrogen) & $0.004(0.002)$ \\
\hline
\end{tabular}

The evaluators estimated that the Visitor Center Complex saves 181 tons $(164,000 \mathrm{~kg})$ of CO $2,160 \mathrm{lbs}$ $(73 \mathrm{~kg})$ of $\mathrm{SO}_{2}$, and $680 \mathrm{lbs}(308 \mathrm{~kg})$ of $\mathrm{NO}_{\mathrm{X}}$ annually as compared to emissions resulting from source energy consumption in the base case, as shown in Table 5.12. For this calculation, a $10 \%$ transmission loss is assumed from delivering electricity from the point of generation to the site.

Table 5-12 Emissions Reduction Summary

\begin{tabular}{|l|c|c|c|}
\hline & $\begin{array}{c}\text { Base-case } \\
\text { Emissions } \\
\text { tons }(\mathrm{kg})\end{array}$ & $\begin{array}{c}\text { November 2001-October } \\
\text { 2002 Emissions } \\
\text { tons }(\mathrm{kg})\end{array}$ & $\begin{array}{c}\text { Emissions Reductions } \\
\text { (Amount Saved) } \\
\text { tons }(\mathrm{kg})\end{array}$ \\
\hline \hline $\mathrm{CO}_{2}$ & $279(253,000)$ & $98(89,000)$ & $181(164,000)$ \\
\hline $\mathrm{SO}_{2}$ & $0.13(118)$ & $0.05(45)$ & $0.08(73)$ \\
\hline $\mathrm{NO}_{\mathrm{X}}$ & $0.53(480)$ & $0.19(172)$ & $0.34(308)$ \\
\hline
\end{tabular}




\section{Subsystem Evaluations}

NREL evaluated the unique subsystems of the building, including the HVAC system, lighting, daylighting, and PV system. In addition, a comfort evaluation of occupants and an energy analysis of the Comfort Station were also performed.

\subsection{HVAC Evaluation}

We evaluated two years of indoor and outdoor dry-bulb temperature data from 2001 to 2003 and organized the years into seasons. We defined winter as October 1 through April 30 and summer as May 1 through September 30. The comfort data starts in May 1, 2001, whereas the energy performance data starts in November 1, 2001. A histogram of the outdoor dry-bulb temperature is shown in Figure 6-1. The averages and standard deviations were similar for each year, but the histogram shows that there were $43 \%$ more hours of outdoor dry-bulb temperatures above $95^{\circ} \mathrm{F}\left(35^{\circ} \mathrm{C}\right)$ in 2002 than in 2001 . In addition, the temperatures in the winter of 2001-2002 were colder than the winter of 2002-2003.

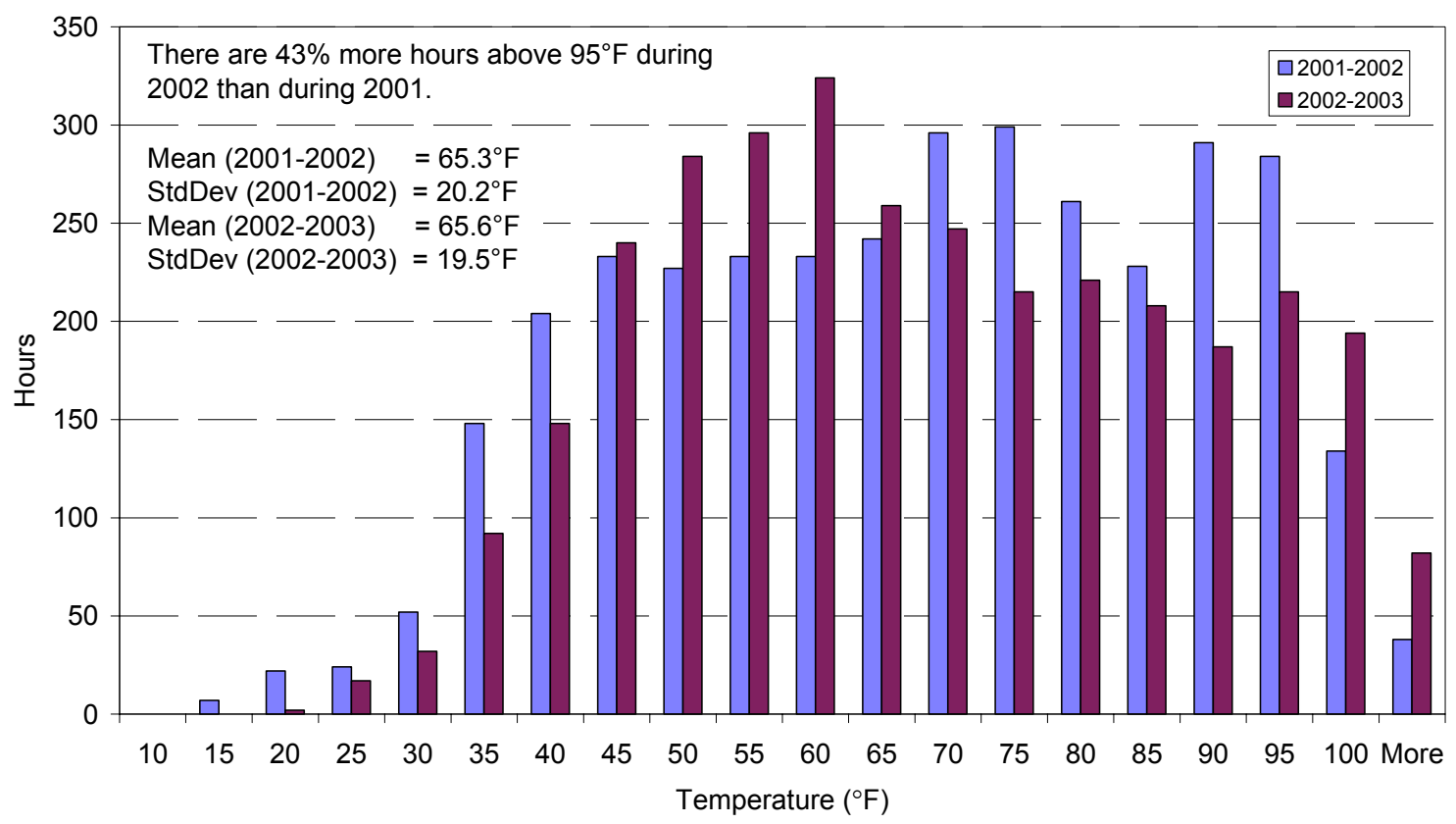

Figure 6-1 Histogram of outdoor dry-bulb temperatures during occupied hours

Further analysis of the outdoor temperatures show that the heating degree days at $65^{\circ} \mathrm{F}$ (HDD) between the two years of analysis did not change significantly; however, the cooling degree days at $75^{\circ} \mathrm{F}$ (CDD) in 2002-2003 increased by 30\% compared to 2001-2002, see Table 6-1. Note that these values do not match the values for the Zion measured data in Table 5-4 because the range of the datasets is different.

Table 6-1 Heating and Cooling Degree Days for 2001-2002 and 2002-2003 Data

\begin{tabular}{|l|c|c|}
\hline & $\begin{array}{c}\text { HDD } \\
\left(\mathbf{6 5}^{\circ} \mathrm{F} / \mathbf{1 8}^{\circ} \mathrm{C}\right)\end{array}$ & $\begin{array}{c}\text { CDD } \\
\left(\mathbf{7 5}^{\circ} \mathrm{F} / \mathbf{2 4}^{\circ} \mathrm{C}\right)\end{array}$ \\
\hline \hline 2001-2002 Data & 3,508 & 728 \\
\hline 2002-2003 Data & 3,505 & 946 \\
\hline
\end{tabular}


This increase in outdoor temperature over the two-year monitoring period created many challenges on how to effectively cool the space. As seen in subsequent sections, the temperatures were easier to maintain during 2001, when the outdoor temperatures were lower. During the winter, the heating set point was controlled by the occupants. There is sufficient heating capacity to maintain set point temperatures at $72^{\circ} \mathrm{F}\left(22^{\circ} \mathrm{C}\right)$ or below. The only limitation of heating was the demand limiting controls to help control costs (Section 5.2.3.1).

The majority of the energy used for the HVAC system went to the heating panels, while the cooling system used very little energy, as shown in Figure 6-2. When the outdoor temperature was between 60$75^{\circ} \mathrm{F}\left(16-24^{\circ} \mathrm{C}\right)$, the building used very little energy for heating or cooling. The thermal envelope contributes to large heating and cooling energy reductions during the swing seasons.

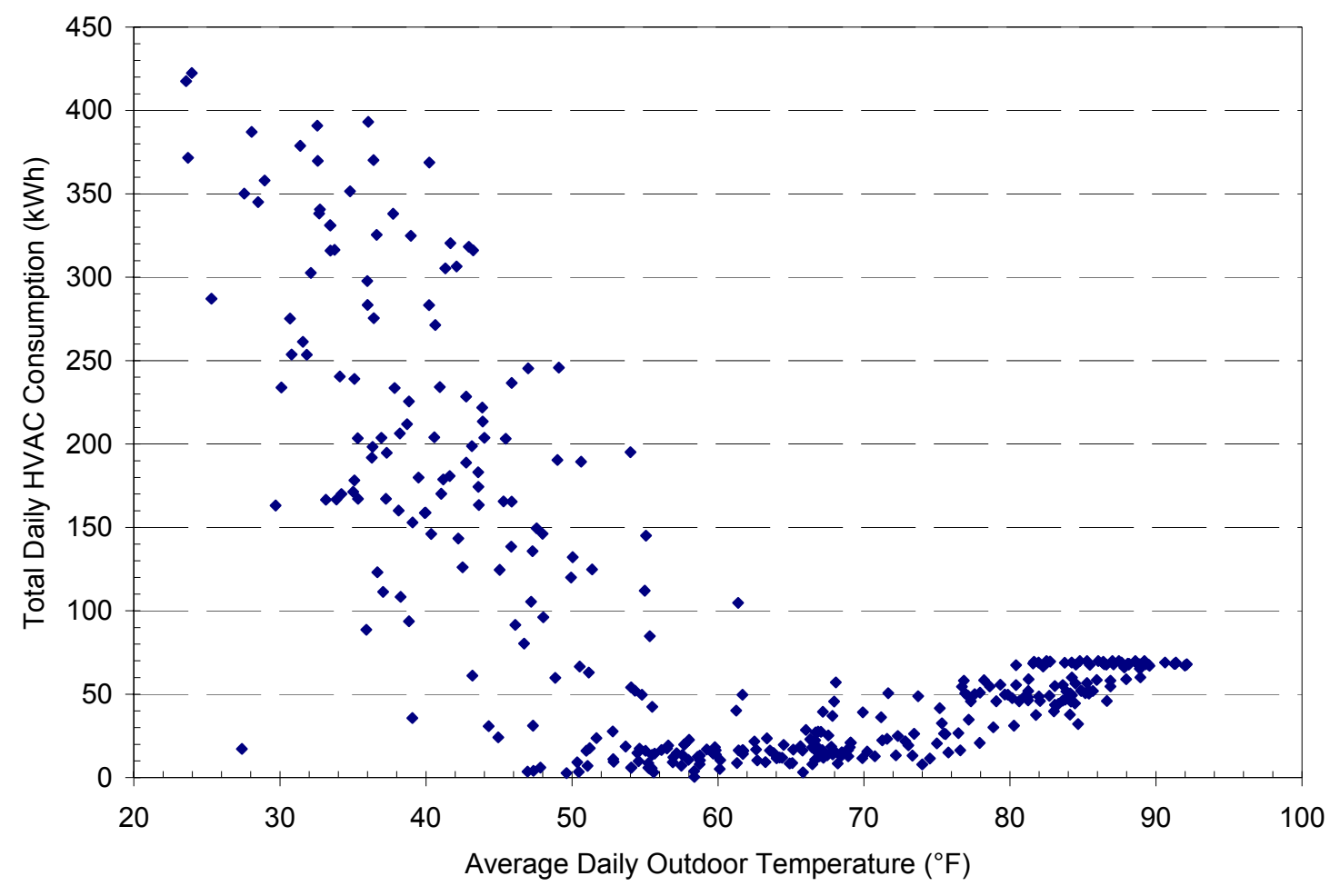

Figure 6-2 HVAC energy consumption as a function of outdoor temperature

\subsubsection{Heating Evaluation Methods}

The heating system includes Trombe walls and electric radiant ceiling panels. We calculated the energy consumption of the electric radiant panels by the BAS based on run time and a one-time load measurement of each panel. We compared the energy use to the base-case values reported in Section 5.4.2. We also compared the energy use between the two winters of collected data.

We measured the thermal gradient through the Trombe wall to approximate the performance.

Thermocouples placed in the wall during construction, combined with portable data loggers, measured the temperature at three locations in the wall from November 29, 2000 to January 25, 2003 (Figure 6-3). The interior temperature sensor is not a measurement of surface temperature, but rather the measurement of the air temperature very close to the surface of the interior Trombe wall. Based on an evaluation of area and temperatures within the wall, we estimated the energy supplied from the Trombe wall to the Visitor Center space. We chose the data set from November 9, 2002 to January 14, 2003. It was also important 
to determine how often the Trombe wall was being a net positive influence on the building, and when it was negatively impacting the building.

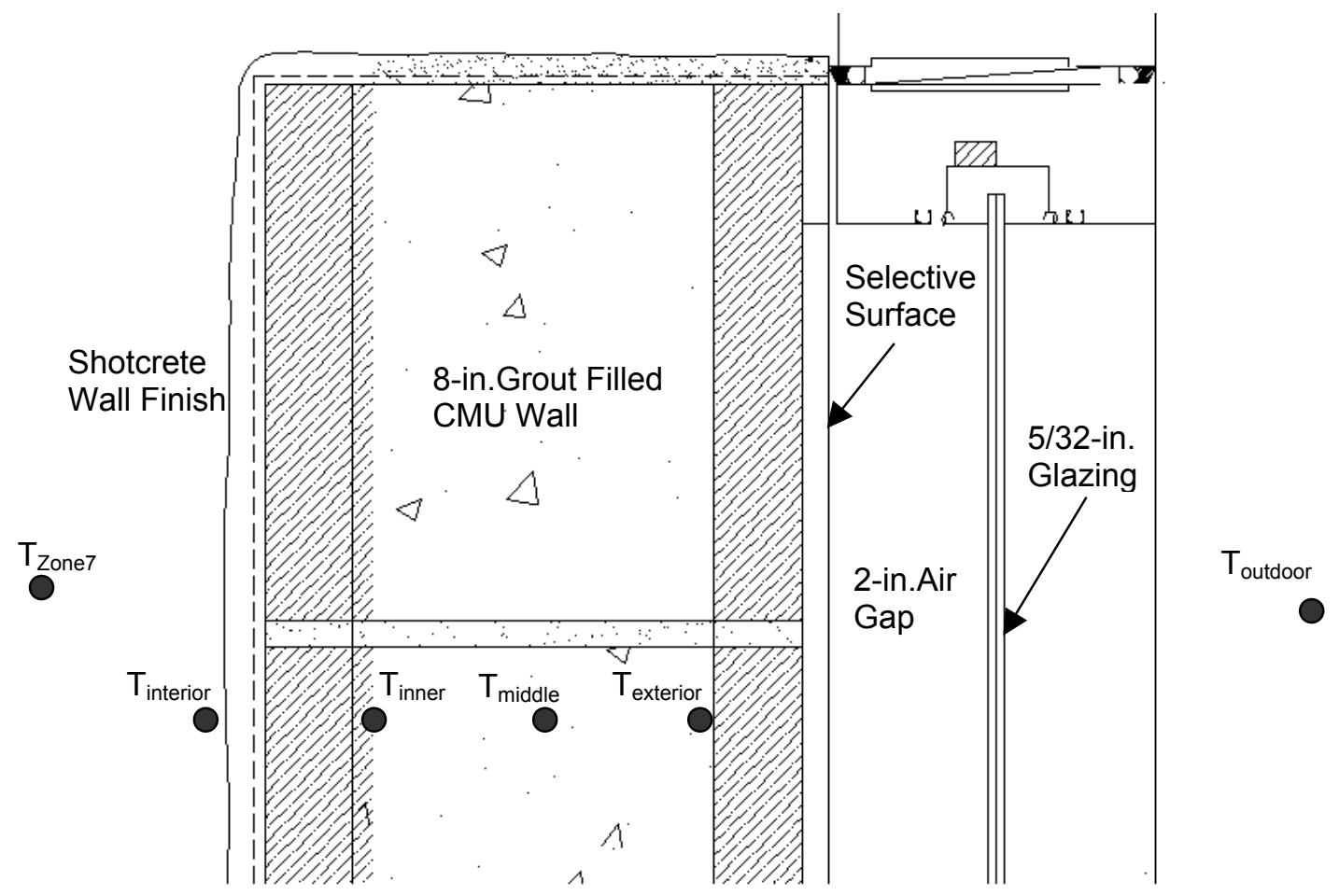

Figure 6-3 Cross section of Trombe wall showing location of temperature sensors

\subsubsection{Heating Evaluation Results}

The Visitor Center heating system is a combination of electric radiant heating and passive solar. The occupants have control over the temperatures during the winter, so it is assumed that if they are uncomfortable, they will adjust the heating set point accordingly. More on comfort is seen in Section 6.4.

The electric heating during the winter of 2001-2002 used 24,571 kWh compared to only $11,442 \mathrm{kWh}$ during the winter of 2002-2003. The base case used 20,608 kW. During the winter of 2001-2002, the Visitor Center used 19\% more energy than the base case, an increase of 3,963 kWh. However, during the winter of 2002-2003, the building used 44\% less energy than the base case, a decrease of 9,166 kWh. The difference can be attributed to many factors, including a warmer winter in 2002-2003, demand controls implementation, and a reduced set point. The average daily monthly energy consumption is shown in Figure 6-4. 


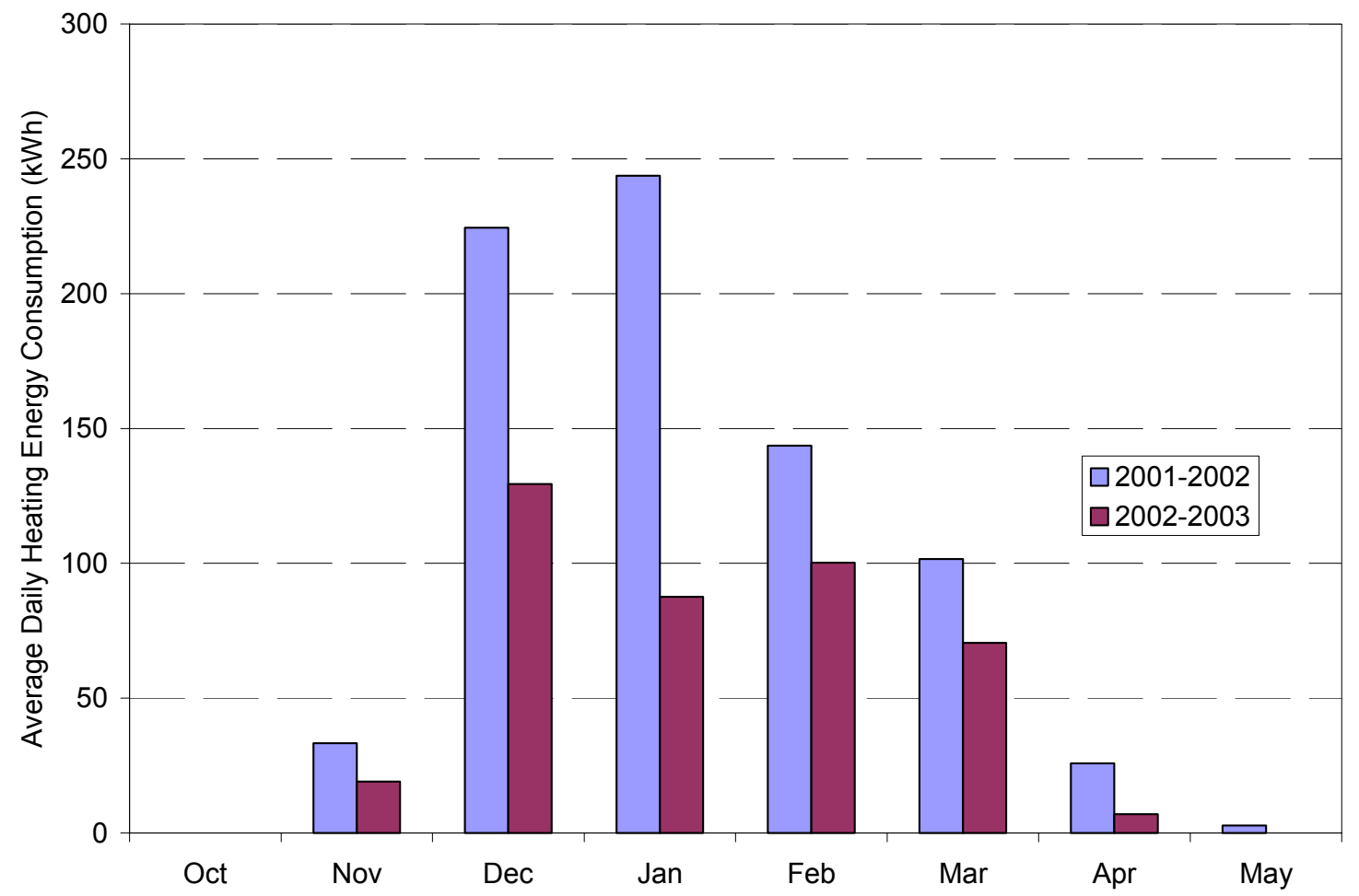

Figure 6-4 Average daily heating energy consumption by month

The electric radiant system provides a large portion of heat to the Visitor Center; however, the Trombe wall is an integral part of the building's heating system as well. To perform the heat transfer calculation on the Trombe wall, several assumptions had to be made, including: a homogeneous wall, a constant density of $130 \mathrm{lbs} / \mathrm{ft}^{3}\left(2,080 \mathrm{~kg} / \mathrm{m}^{3}\right)$, a constant capacitance of $0.22 \mathrm{Btu} / \mathrm{lb} \cdot{ }^{\circ} \mathrm{F}(0.92 \mathrm{~kJ} / \mathrm{kg} \cdot \mathrm{K})$, and the temperature sensors within the wall were equally spaced (ASHRAE 2001). In addition, the heat flow was assumed one-dimensional.

To confirm that the material and temperature homogeneity assumptions were valid, an infrared picture was taken of the Trombe wall during the middle of the heating season (see Figure 6-5). The temperature range across the Trombe wall was around $4^{\circ} \mathrm{F}\left(2.2^{\circ} \mathrm{C}\right)$. The edges of the wall have slightly larger temperature drops, but the majority of the $1,040-\mathrm{ft}^{2}\left(96.6-\mathrm{m}^{2}\right)$ wall was within the $4^{\circ} \mathrm{F}\left(2.2^{\circ} \mathrm{C}\right)$ range. This range was assumed reasonable for the homogeneous assumption of even distribution. Note the uneven temperature distribution in the middle of the interior wall caused by the external shading of the Trombe wall by the window mullions and other exterior wall shading. Also, note the heat bridge in the corner of the building - a typical problem spot. Even with careful detail to make certain the insulation was installed properly, losses from edge affects are still evident. More extensive modeling could be done, but it is beyond the scope of this project. 




Figure 6-5 Infrared picture of Trombe wall during heating season 2/9/2000 at 6:00 p.m.

Using the stated assumption and the internal temperature measurements, we calculated the Trombe wall energy supplied to the building based on published heat flux calculation methods (Balcomb 1998). The objective was to calculate the middle temperature using the previous measured temperatures of the wall using the equations below. We then adjusted the thermal conductivity of the wall until the calculated middle temperature was comparable to the measured middle temperature. We found that the wall had a conductivity of $0.5 \mathrm{Btu} / \mathrm{hr} \cdot \mathrm{ft} \cdot{ }^{\circ} \mathrm{F}(0.86 \mathrm{~W} / \mathrm{m} \cdot \mathrm{K})$. Figure $6-6$ shows the comparison between the calculation and measured temperatures after adjusting the thermal conductivity.

$$
\begin{aligned}
T_{\text {middle }} & =\frac{H \cdot\left(T^{\prime}{ }_{\text {inner }}+T_{\text {exterior }}^{\prime}-T^{\prime}{ }_{\text {middle }}\right)-G \cdot T^{\prime}{ }_{\text {middle }}}{H-G} \\
H & =\frac{k}{\Delta x} \quad G=\frac{\rho C_{p} \Delta x}{\Delta t} \\
\text { Where: } & \rho=\text { density } \\
\mathrm{k} & =\text { thermal conductivity } \\
& \mathrm{x}=\text { thickness of slice } \\
\mathrm{T} & =\text { Temperature } \\
& \mathrm{T}^{\prime}=\text { Previous Temperature } \\
& \mathrm{C}_{\mathrm{p}}=\text { heat capacity } \\
\mathrm{t} & =\text { time }
\end{aligned}
$$




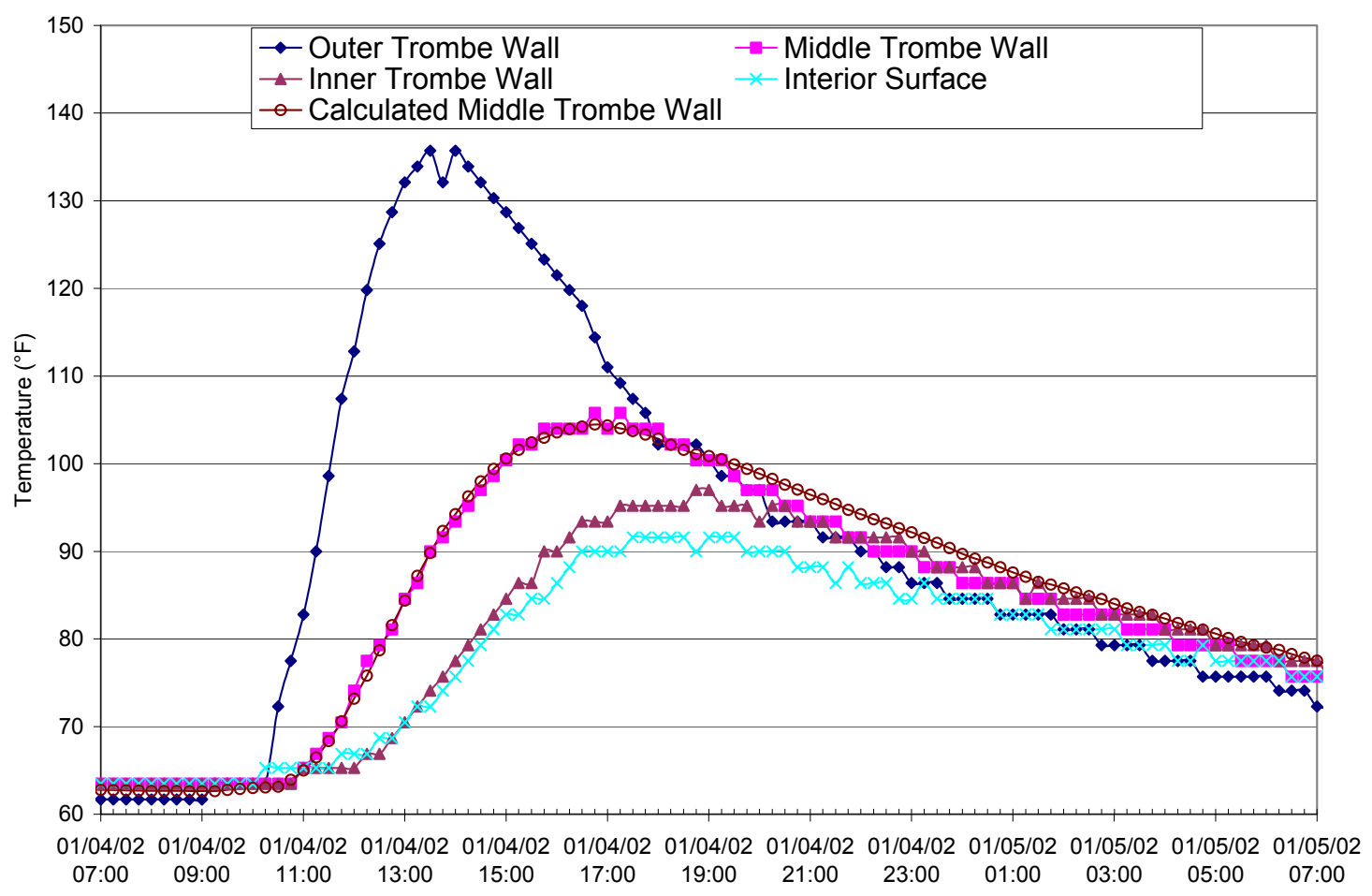

\section{Figure 6-6 Verification of middle Trombe wall temperature after adjusting thermal conductivity}

The amount of energy delivered to the space could be calculated after determining the actual thermal conductivity of the Trombe wall. Visitor Center Trombe wall daily performance during the 2001-2002 heating season is shown in Figure 6-7. During the period of evaluation of the Trombe Wall, the electric radiant heating system used $22,680 \mathrm{kWh}(81,600 \mathrm{MJ})$, with the Trombe wall contributing $20 \%$ of the total heating to the building. The Trombe wall imposed a heating load on the building for only two of the 151 days of the 2001-2002 heating season. For the other 149 heating days, the wall was net positive. The peak heat flux through the wall was $11.2 \mathrm{~W} / \mathrm{ft}^{2}\left(89 \mathrm{~W} / \mathrm{m}^{2}\right)$, or $8.3 \mathrm{~kW}$ over the entire Trombe wall area. The average efficiency of the wall over the 2001-2002 heating season (defined as the heat delivered to the building from the Trombe wall divided by the total solar radiation incident on the exterior of the wall) was $13 \%$.

During the first three months of the 2002-2003 heating season, the total electrical heating energy used was $5,389 \mathrm{kWh}$, while the Trombe wall provided approximately $41 \%$ of the energy or $3,800 \mathrm{kWh}$. This percentage was greater than the previous 2001-2002 heating season of only $20 \%$ due to improved controls of the electrical heating system and differences in weather. 




Figure 6-7 Trombe wall and heating system performance, 2001-2002 heating season

The heat added to the Visitor Center from the Trombe wall during cooling months is a concern, especially in the enclosed offices on the south side of the Visitor Center. Although the Trombe wall is shaded by overhangs, diffuse radiation hitting the wall is transferred to the building. Because of the evaporative cooling system, this load is not generally seen by the building, although specific zones suffer from insufficient ventilation. We recommend that further research be completed in determining the summer Trombe wall loads and ways of reducing the impact. External shade cloths in the summer are a possible option.

In the initial design, these offices were on the north side of the building and summer Trombe wall heat gain to the offices was not a concern. With the offices located directly next to the Trombe walls in the As-built design and separated from the cool air sources, overheating in these spaces can be a problem. This is discussed further in the next section. For buildings with conventional air-conditioning systems, careful Trombe wall design is essential so that summer gains are minimized. If buildings are flushed with evaporative cooling, the summertime cooling loads generated by the Trombe walls are not a problem.

We conducted a further analysis to determine the delay of heat gain into the space because of the Trombe wall. The analysis involved measuring the temperature distribution through the wall as a function of time. A day was chosen that had very large insolation to preheat the wall, while the previous day had little insolation so the wall started with as little "charge" as possible. In addition, the outdoor temperature was relatively low to show the passive solar component of the Trombe wall. Figure 6-8 shows how the heat is slowly transferred into the building. The shifting of the temperature profile peaks shows the time delay of the heat transfer from the exterior of the Trombe wall to the interior. It takes approximately 4 hours for the heat to migrate from the exterior wall surface to the interior wall surface. In this case, the interior surface of the Trombe wall provided the most heating from 5:00-7:00 p.m. Temperatures at the interior 
surface can reach over $100^{\circ} \mathrm{F}\left(37.7^{\circ} \mathrm{C}\right)$ during certain times of the year. This warm surface provides radiant heating to the occupants. The result is that occupants in the building with a view factor of the radiant surface should be comfortable at lower space temperatures. No attempt was made in this study to quantify the radiant effects of the wall on comfort. The NPS staff can control the temperature of the building via the thermostats, so savings from radiant comfort would be connected with the heating consumption of the building.



Figure 6-8 Trombe wall temperature transients over a 24-hour period

\subsubsection{Cooling Systems Evaluation Methods}

NREL determined cooltower performance by evaluating energy use, water consumption, and the ability of the natural ventilation, the cooltowers, and the fans to cool the space. We calculated the energy consumed by water pumps in the cooltowers and circulation with the BAS based on a one-time power measurement and run time. Water consumption was determined by measuring the water flow to and from the cooltowers during operation. We measured the ability of the clerestory windows, the cooltowers, and the fans to cool the space by collecting indoor zone temperatures and through occupant feedback. This data is reported in the comfort analysis section.

\subsubsection{Cooling Systems Evaluation Results}

The cooltowers cool the building using only a small circulation pump. Circulation fans were added in August 2001 to help push cool air into the office areas of the building. The total cooling energy (both cooltower pumps and circulation fans) for the Visitor Center Complex during 2001 was $4,940 \mathrm{kWh}$, or $7.5 \%$ of the total consumed energy, whereas for 2002 , the total cooling energy consumed was $7,300 \mathrm{kWh}$, or $8.4 \%$ of the total consumed energy. (The differences between the numbers can be attributed to many variables including the warmer summer during 2002.) The cooling energy intensity was $1.28 \mathrm{kBtu} / \mathrm{ft}^{2} \cdot \mathrm{yr}$ 
$\left(14.5 \mathrm{MJ} / \mathrm{m}^{2} \cdot \mathrm{yr}\right)$, which was $77 \%$ less than a typical building in the western United States that uses $5.5 \mathrm{kBtu} / \mathrm{ft}^{2} \cdot \mathrm{yr}\left(62.5 \mathrm{MJ} / \mathrm{m}^{2} \cdot \mathrm{yr}\right)($ EIA 2002$)$.

The building uses control algorithms to precool the building during nighttime periods if certain conditions are met. The controls check the high temperature for the current day and the previous day. If the highs are greater than $90^{\circ} \mathrm{F}\left(32.2^{\circ} \mathrm{C}\right)$, then the building will perform night cooling for the next day. The purpose of the night cooling is to remove any excess heat in the building, such as Trombe wall heat, during the night while the temperatures are cooler. In addition, less energy is needed to cool the building because the internal loads are smaller. In some cases, the cost of energy is less during nighttime hours because of lower demands. The day following the night cooling period allows the building to "float" to the temperature set point instead of having to drop to the cooling set point.

The next metric in determining the cooling system performance was to evaluate the amount of water consumed in the evaporative cooling process. Water consumption is a concern because of the semi-desert climate and the scarcity of water resources. From the installed water meters, 111,200 gallons $(420,938$ liters) of water were consumed during 2002 for the two cooltowers in the Visitor Center. The water consumption was related to many variables such as temperature, relative humidity, and wind speed, with a loose correlation to the outdoor dry-bulb temperature shown in Figure 6-9. Due to flaws in the design of the cooltower plumbing, there was unnecessary water use, which occurred when the sump pit would overflow during on/off cycling of the pumps. The cycling of the pumps and sump pit overflow resulted in a $10 \%$ increase of water consumption. The cycling occurred during the swing season when the cooling was not required all the time. During this time, the pumps would run and saturate the pads and the sump pit would fill up. The pumps would turn off because cooling was no longer needed and all the water in the pads would drain into the full sump pit causing the pit to overflow.

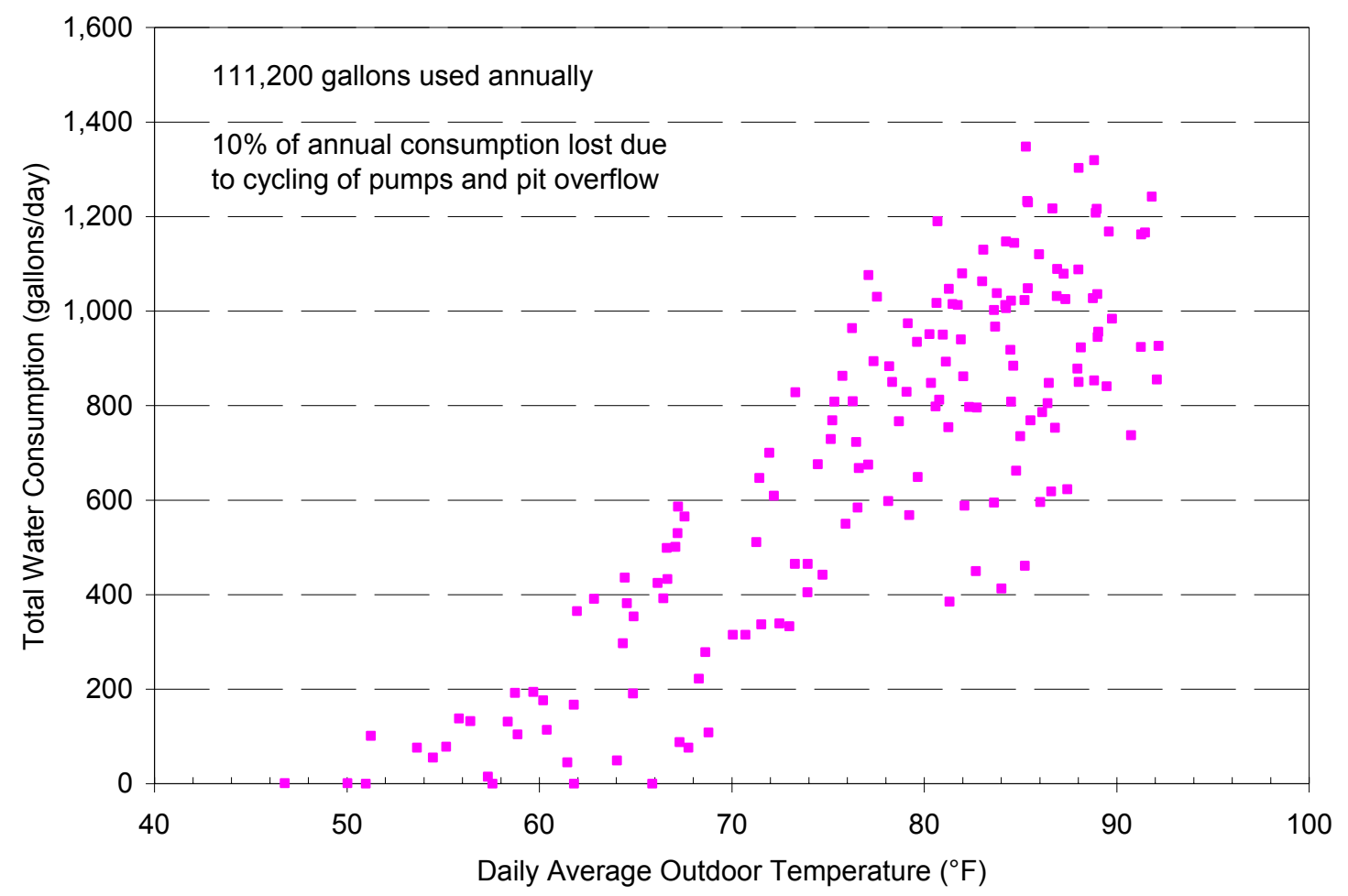

Figure 6-9 Water consumption versus daily average outdoor temperature (Summer 2002) 
Another measure of cooltower success and excess water consumption is the effectiveness of delivering the evaporative cooled air to the building. By design, the dry air enters the building and picks up moisture. This air enters the building. However, some of the air may exit through the pads into the environment driven by evaporation on the exterior of the pads or cross-flow through the top of the tower, which results in more evaporation of water than would be expected with traditional evaporative technologies. The towers contained a simple internal diagonal blocking device to minimize this effect (see Figure 6-10). The tower pads are not shaded from direct sunlight, which increases the evaporation rate and as well as degrading the pads by UV exposure.

To estimate the effects of water evaporation, a hot-wire flow meter was used to estimate airflows from the towers. These values are highly variable and difficult to capture. The inlet air conditions were also computed as well as the flow rates. As an estimate, $50 \%$ of the water is not used for cooling within the building; however, much more detailed measurements would be needed to validate and fine-tune this number. It does result in the conclusion that the efficiency of the towers could be improved with respect to water consumption. Several recommendations regarding the cooltowers emerged from this analysis as seen in Section 7.2.4.



Figure 6-10 Plastic blocking device for cooltowers

The natural ventilation and cooltowers have provided adequate cooling for the Visitor Center Complex, with occasional periods of overheating and low flow rates. There were several days when the cooltowers could not meet the desired comfort range. This is typical of direct evaporative cooling. The system performed as well as a conventional direct evaporative cooling system. The limitation of the system is that the air outdoors must be dry, which is the case the majority of the time.

There were problems interfacing the automatic windows in the building with the BAS. If the windows fail to open, the evaporative cooler has no relief and hence no airflow. The window operation technology was a weak point in the system. It is essential that the windows are open for air to flow. The actuators did not have feedback so the state of the windows could not be determined. This was fixed by running an open/close cycle every night to make sure the windows are synchronized with the BAS. 


\subsection{PV System Evaluation}

\subsubsection{PV System Evaluation Method}

The evaluators used a PV simulation tool to determine the expected performance of the array. The expected PV production was compared with the actual data collected by the BAS to determine the system performance. NREL monitored the performance of the PV system by measuring horizontal and vertical insolation, PV system AC production, and outdoor weather conditions.

We used a PV system simulation tool called PVSyst v3.2 (Mermoud 1996) to calculate expected annual performance of the PV system. Inputs to this model include PV panel size and operational characteristics, inverter size and operational characteristics, array configuration and wiring details, array tilt and azimuth, and hourly weather data. System specific inputs, such as shading and array wiring losses, are also simulated. The simulation approximated the cell temperatures based on the default thermal properties of the specific mounting configuration. The procedure used for simulating array shading from trees and the canyon walls is included in Appendix D.

We used the Sandia Photovoltaic Performance I-V Curve Tracer (King et al. 1998) to evaluate the effects of operating voltage on PV production. We used this model to create (I-V) and power-voltage (P-V) curve traces for a complete subarray at varying cell temperatures and insolation levels. With a specified array wiring configuration and the manufacturer's PV panel ratings at standard test conditions of 1000 $\mathrm{W} / \mathrm{m}^{2}$ and $77^{\circ} \mathrm{F}\left(25^{\circ} \mathrm{C}\right)$ cell temperature, expected I-V and P-V curve traces were generated with the Sandia I-V Curve Tracer model.

\subsubsection{PV System Evaluation Results}

\subsubsection{Measured Data Results}

The PV system offsets approximately $15 \%$ of the loads during the spring and summer months. It offsets less than $5 \%$ of the load during the winter because of the higher electrical loads from heating and reduced PV production. During the monitored year, the PV system produced a net 7,861 kWh (building normalized to $2.3 \mathrm{kBtu} / \mathrm{ft}^{2} \cdot \mathrm{yr}\left(26.1 \mathrm{MJ} / \mathrm{m}^{2} \cdot \mathrm{yr}\right)$, or $1,092 \mathrm{kWh} / \mathrm{kW}$ of installed capacity. The PV system offsets about $8 \%$ of the total annual energy load. Table $6-2$ provides a tabular summary of the monthly consumption, production, net purchased, maximum production, and percent load met by PV. The total electricity consumed is a summation of all the electrical end uses in the Visitor Center, Comfort Station, and the Fee Station. The net purchased electricity is the difference between the total electricity consumed in the building for a month and the total PV electricity produced for the month. The maximum 15-minute averaged PV production of $5.43 \mathrm{~kW}$ occurred in March during a cool period with good solar resources. 
Table 6-2 PV Performance: November 1, 2001 through October 31, 2002

\begin{tabular}{|c|c|c|c|c|c|}
\hline & $\begin{array}{c}\text { Total } \\
\text { Consumption } \\
\text { (kWh) }\end{array}$ & $\begin{array}{c}\text { PV } \\
\text { Production } \\
\text { (kWh) }\end{array}$ & $\begin{array}{c}\text { Net } \\
\text { Purchased } \\
\mathbf{( k W h )}\end{array}$ & $\begin{array}{c}\text { Max PV } \\
\text { Power } \\
\mathbf{( k W )}\end{array}$ & $\begin{array}{c}\text { \% Load Met } \\
\text { by PV }\end{array}$ \\
\hline Nov-01 & 6,286 & 355 & 5,930 & 3.95 & $5.6 \%$ \\
\hline Dec-01 & 12,191 & 319 & 11,872 & 3.88 & $2.6 \%$ \\
\hline Jan-02 & 12,947 & 428 & 12,519 & 4.13 & $3.3 \%$ \\
\hline Feb-02 & 8,160 & 561 & 7,600 & 4.93 & $6.9 \%$ \\
\hline Mar-02 & 7,592 & 785 & 6,807 & 5.43 & $10.3 \%$ \\
\hline Apr-02 & 5,880 & 779 & 5,101 & 5.15 & $13.2 \%$ \\
\hline May-02 & 5,766 & 965 & 4,801 & 5.39 & $16.7 \%$ \\
\hline Jun-02 & 6,192 & 919 & 5,273 & 5.16 & $14.8 \%$ \\
\hline Jul-02 & 7,257 & 850 & 6,407 & 4.83 & $11.7 \%$ \\
\hline Aug-02 & 6,950 & 826 & 6,124 & 4.94 & $11.9 \%$ \\
\hline Sep-02 & 6,217 & 571 & 5,646 & 4.64 & $9.2 \%$ \\
\hline Oct-02 & 7,440 & 503 & 6,937 & 4.22 & $6.8 \%$ \\
\hline YTD & 92,878 & 7,861 & 85,017 & 5.43 & $8.5 \%$ \\
\hline Totals & & & & & \\
\hline
\end{tabular}

The PV system is a high-value feature to the building even though it displaces a small part of the total energy load. During daylit hours, the system can provide power for business operations without relying on power stored in the UPS system battery bank. This system met 40 power outages ranging from 1 second to 8 hours during the monitoring period.

Figure 6-11 shows the average hourly power profile for AC PV production for each month from November 2001 through October 2002. The monthly comparison of PV production profiles demonstrates the drastic reduction in PV production from summer to winter months. The maximum 15-minute average AC PV production varies from $4.7 \mathrm{~kW}$ in May to $2.2 \mathrm{~kW}$ in December. The primary cause of this is the reduced solar radiation in the winter. Also evident in Figure 6-11 is the nonsymmetrical power profile for each of the months. The time is Mountain Standard Time and does not include the daylight savings time change. Generally, the afternoon AC PV production is less than the morning production because of the afternoon shading from the trees. 


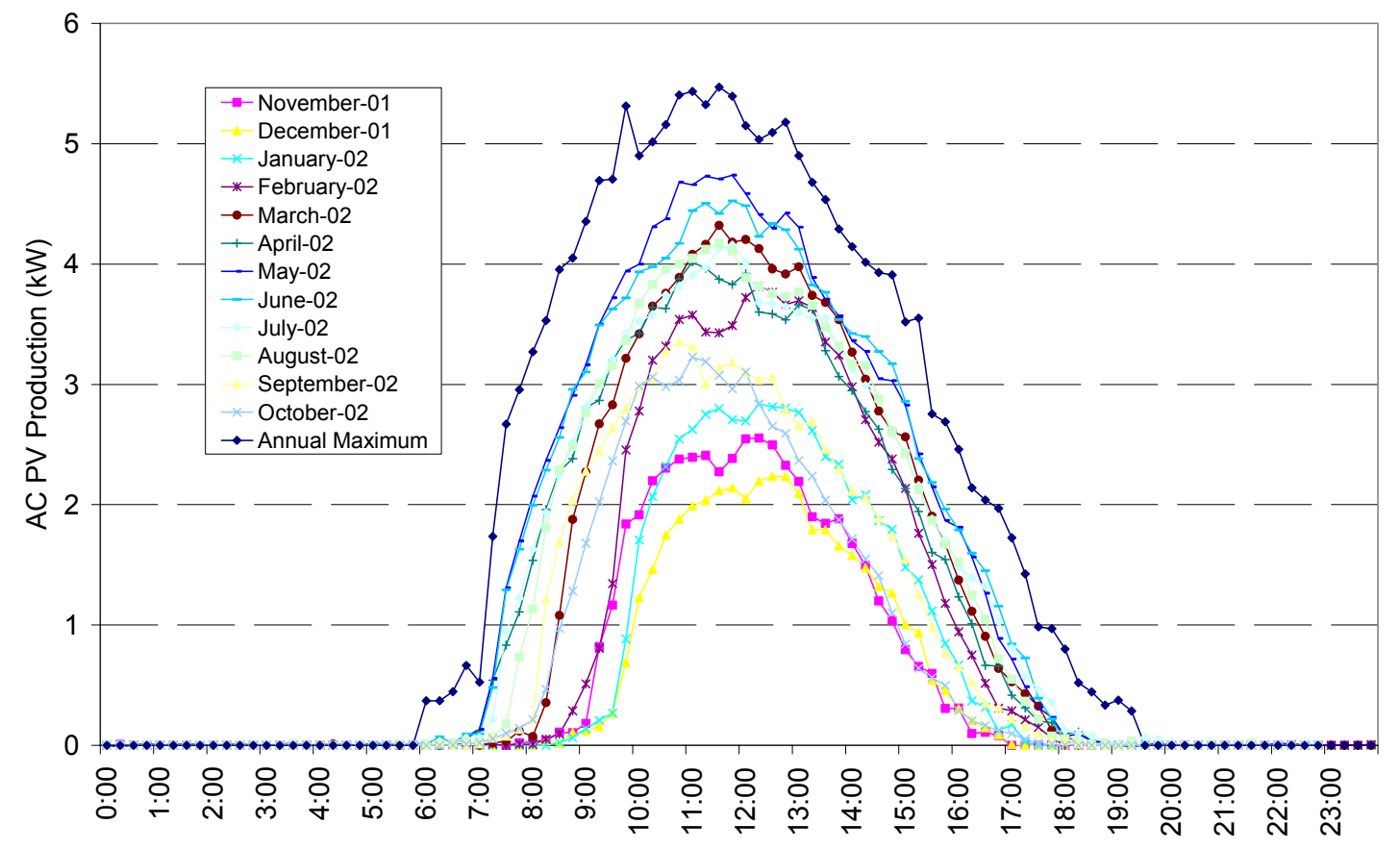

Figure 6-11 Average hourly AC power profile by month for PV production, November 2001 through October 2002

\subsubsection{PV System Simulations}

The PVSyst simulated system losses are summarized in Figure 6-12 and detailed in Table 6-3. The expected maximum DC power point (Pmpp) is $7.2 \mathrm{~kW}$ for global insolation at $92.9 \mathrm{~W} / \mathrm{ft}^{2}\left(1000 \mathrm{~W} / \mathrm{m}^{2}\right)$ and cell temperatures of $77^{\circ} \mathrm{F}\left(25^{\circ} \mathrm{C}\right)$. The modeled system losses include wiring and connection resistance, diode losses, thermal inefficiencies, and panel parameter mismatches. The incidence angle reflectance losses are accounted for in the simulation by the incidence angle modifier (IAM). The thermal inefficiencies are determined based on simulated module temperatures, with losses totaling $11.9 \%$. The expected maximum DC power point at a cell temperature of $126^{\circ} \mathrm{F}\left(52^{\circ} \mathrm{C}\right)$ and global insolation of $92.9 \mathrm{~W} / \mathrm{ft}^{2}\left(1000 \mathrm{~W} / \mathrm{m}^{2}\right)$ is $5.7 \mathrm{~kW}$. This number corresponds to an overall simulated system loss of $20.9 \%$ at these conditions. 




Figure 6-12 Modeled array losses

Table 6-3 Summary of PV System Losses at $\mathbf{1 0 0 0 ~} \mathbf{W} / \mathrm{m}^{2}, \mathbf{7 7}^{\circ} \mathrm{F}\left(\mathbf{2 5}{ }^{\circ} \mathrm{C}\right)$
\begin{tabular}{|l|c|}
\hline \multicolumn{1}{|l}{ Category } & $\begin{array}{c}\text { Percent } \\
\text { Loss }\end{array}$ \\
\hline Module Quality Loss & 3.0 \\
\hline Module mismatch & 2.9 \\
\hline IAM (Diffuse, beam $\left.40^{\circ}\right)$ & 1.8 \\
\hline Modules Temperature $=51.2^{\circ} \mathrm{C}$ & 11.9 \\
\hline Wiring Resistance $(10 \mathrm{~m} \Omega)$ & 1.8 \\
\hline Series Diode Loss $(\mathrm{V}=0.7 \mathrm{~V})$ & 1.0 \\
\hline \hline Global Loss (Pmpp $=5.71 \mathrm{~kW})$ & $20.9 \%$ \\
\hline
\end{tabular}

To model the expected annual performance, we used a typical meteorological year weather dataset for Cedar City, Utah (60 miles north of Zion). An array tilt angle of $18.3^{\circ}$ at a southern azimuth was modeled. We modeled the PV array operating voltage at 53.6 VDC (direct-current voltage) because this was the float voltage set point of the inverters.

The Sandia Photovoltaic Performance I-V Curve Trace results are shown in Figure 6-13. This figure gives an example of the Curve Tracer model. The Curve Tracer model calculated instantaneous I-V and $\mathrm{P}-\mathrm{V}$ traces for a complete subarray at varying weather conditions, cell temperatures, and insolation levels, as shown in Figure 6-13. Inputs included PV module size and type, array wiring configuration, and environmental conditions. NREL researchers used the Curve Tracer model to evaluate DC operating voltages. The effect of fixed array operating voltage was evaluated by comparing the voltage set point to 
a simulated maximum power point. The PVSyst model was also used to evaluate the annual consequences of a fixed voltage PV system as compared to a maximum power-point tracking system.

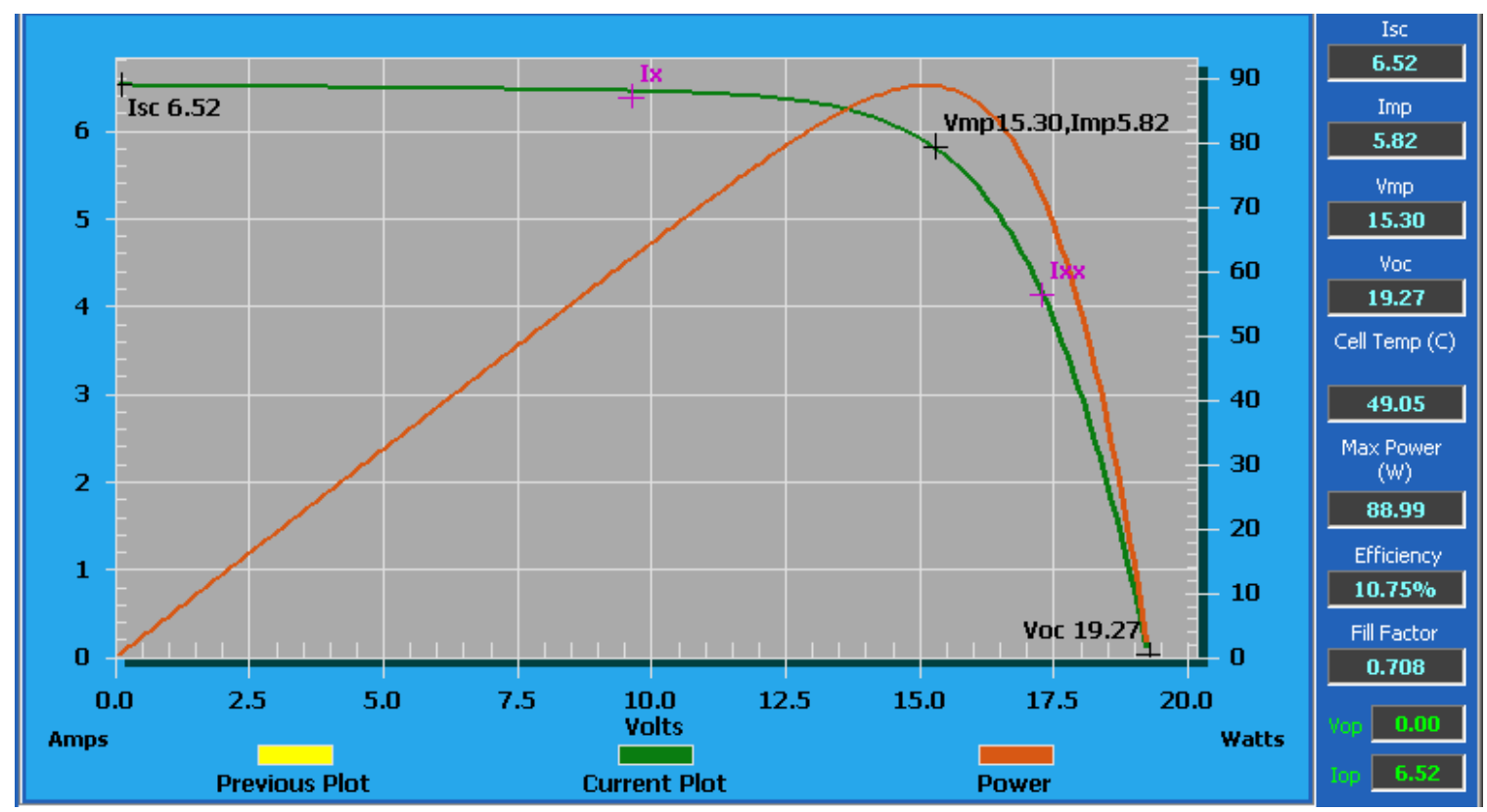

Figure 6-13 Sandia PV performance model I-V curve tracer model for the Zion PV system

Figure 6-14 provides a monthly summary of the effects of horizon and tree shading. Horizon shading is a result of the canyon walls. The tree shading can be seen in an actual photo in Figure 6-15 and in the simulation photo in Figure 6-16. 




Figure 6-14 PV production for unshaded, horizon shaded, and horizon and tree shaded simulations

For a typical meteorological year in Cedar City without any array shading, the estimated production is $9,535 \mathrm{kWh} / \mathrm{yr}$. The simulated annual performance of this model is $16 \%$ greater than the measured production. When the canyon wall horizon shading is considered, the array would produce $8,912 \mathrm{kWh} / \mathrm{yr}$. Annual losses of $7 \%$ are expected because of canyon wall shading. The simulated annual production for the model that includes Cedar City weather data, canyon shading, and tree shading is $8,278 \mathrm{kWh} / \mathrm{yr}$. Annual losses of $7 \%$ are expected because of tree shading. This model represents the expected performance for this system for a typical weather year. With all losses accounted for, the model predicts 4\% more production than was measured from November 2001 through October 2002.

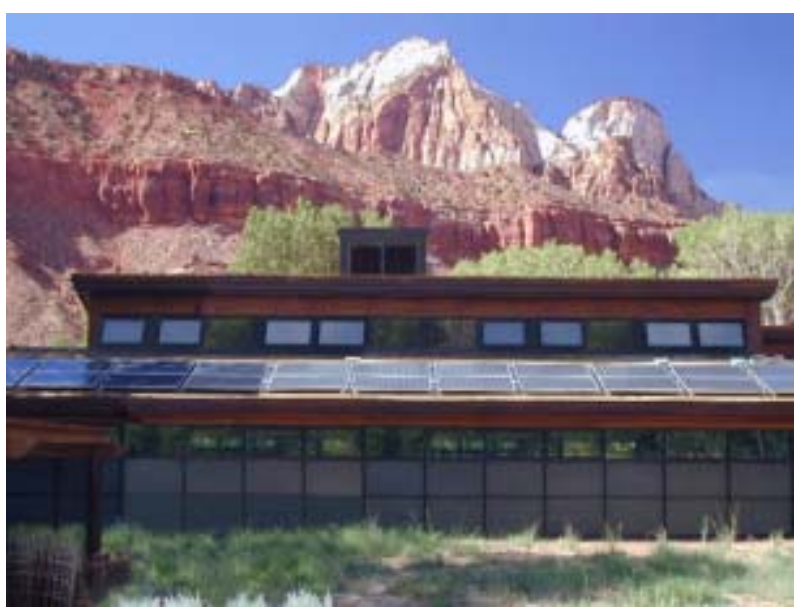

Figure 6-15 Photo of shaded PV panels (left side of photo) 


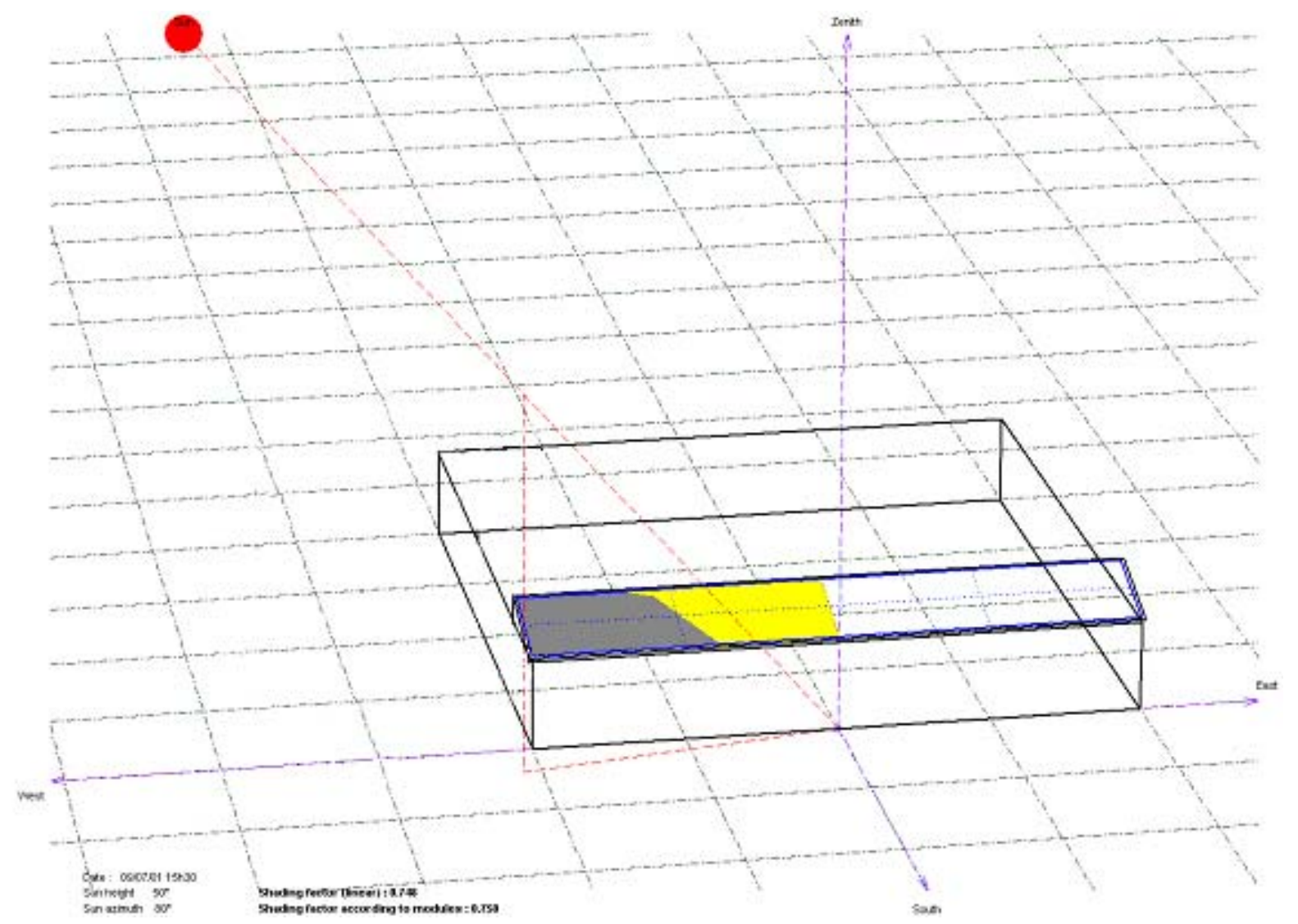

Figure 6-16 Model of tree shading of PV array, 3:30 p.m. July 9, 2000

To provide an accurate comparison of measured annual PV performance to the simulated PV performance, the typical meteorological year at Cedar City, Utah, is considered. In Cedar City, there is an average of $173.2 \mathrm{kWh} / \mathrm{ft}^{2}\left(1,967 \mathrm{MJ} / \mathrm{m}^{2}\right)$ of global horizontal radiation per year. Note that the measured values at the Visitor Center include the effects from the canyon walls shading the sensor; however, the sensor is not shaded by any foliage.

During the measurement period, there was $163.8 \mathrm{kWh} / \mathrm{ft}^{2}\left(1,860 \mathrm{MJ} / \mathrm{m}^{2}\right)$ of global radiation available. This amount is $5 \%$ less solar radiation than a typical year in Cedar City. To determine this effect on the simulated performance, a weather file based on measured environmental conditions at the Visitor Center was used to generate a model that would adequately represent the PV performance from November 2001 through October 2002. The simulated PV production using the measured weather file and the horizon and tree shading models were simulated to be $8,092 \mathrm{kWh} / \mathrm{yr}$ or $1 \%$ more than the measured PV production. The close match between simulated PV performance and measured PV production suggests that the PV system has operated with minimum unaccounted for system losses.

\subsubsection{Maximum Power Point Tracking}

A potential performance-limiting feature of the Zion PV system is the fixed-array voltage control. The $\mathrm{PV}$ array operating voltage is set at 53.6 VDC, as this is the float-voltage set point of the inverters. The maximum power point of the array is often greater than the fixed-voltage set point, as shown in the power-voltage curves in Figure 6-17 and Figure 6-18.

For summer weather conditions of $104^{\circ} \mathrm{F}\left(40^{\circ} \mathrm{C}\right)$ and a wind speed of $3.28 \mathrm{ft} / \mathrm{s}(1 \mathrm{~m} / \mathrm{s})$, the Sandia Curve Tracer predicts a maximum power point of $54 \mathrm{VDC}$ to $59 \mathrm{VDC}$, depending on insolation (Ic) and cell 
temperature (Tc). For winter weather conditions of $32^{\circ} \mathrm{F}\left(0^{\circ} \mathrm{C}\right)$ and a wind speed of $9.8 \mathrm{ft} / \mathrm{s}(3 \mathrm{~m} / \mathrm{s})$, the Sandia Curve Tracer predicts a maximum power point of 69 VDC to 73 VDC, depending on insolation and cell temperature.

A maximum power-point tracker was simulated with PVSyst to determine the potential PV production if this type of voltage control was used. The predicted annual production of the PV system with a maximum power-point tracker and current shading issues would be $9,826 \mathrm{kWh} / \mathrm{yr}$. This number corresponds to a production increase of $16 \%$ due to maximum power-point control as compared to the fixed 53.6 VDC control.

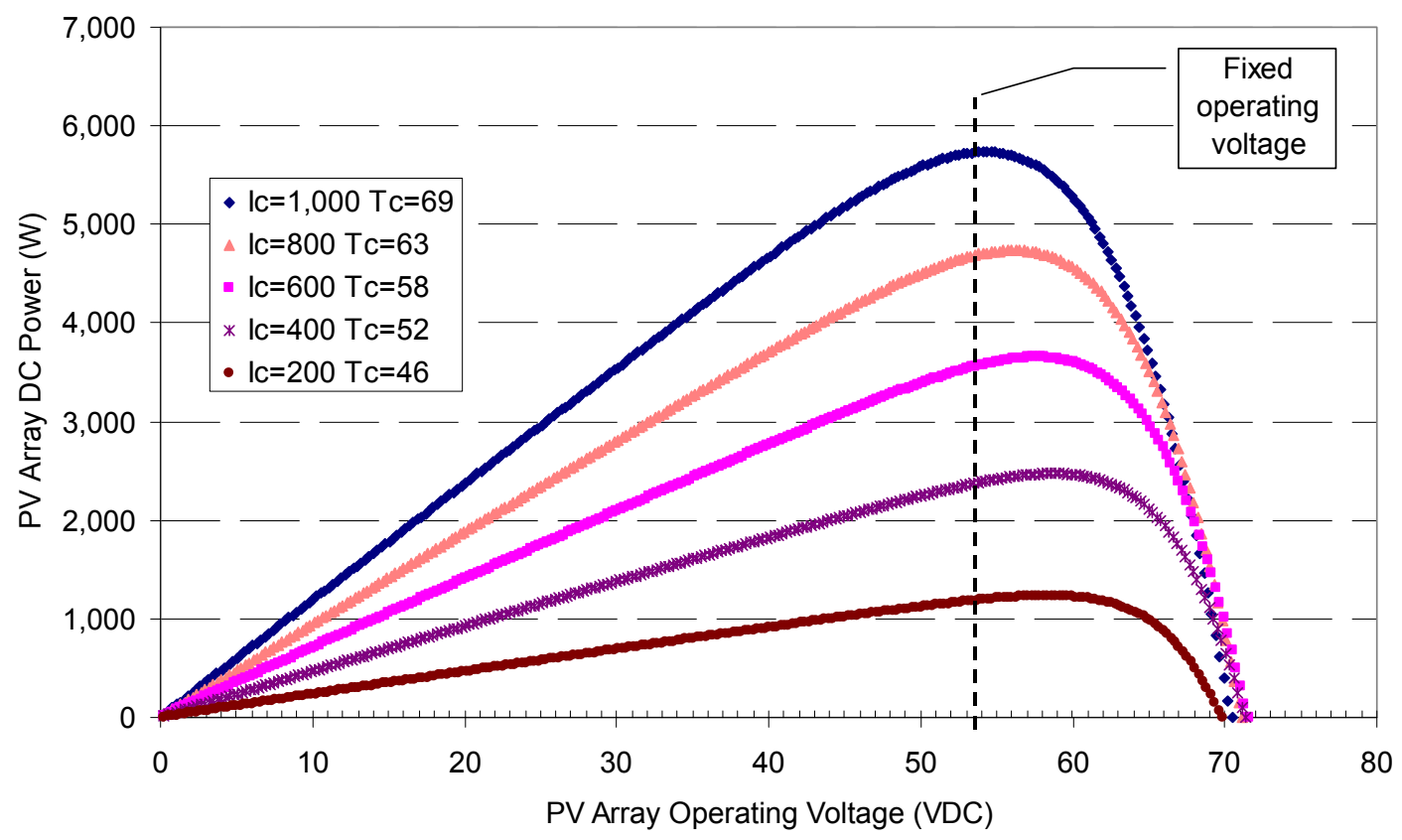

Figure 6-17 Simulated power-voltage curve traces for summer weather conditions 


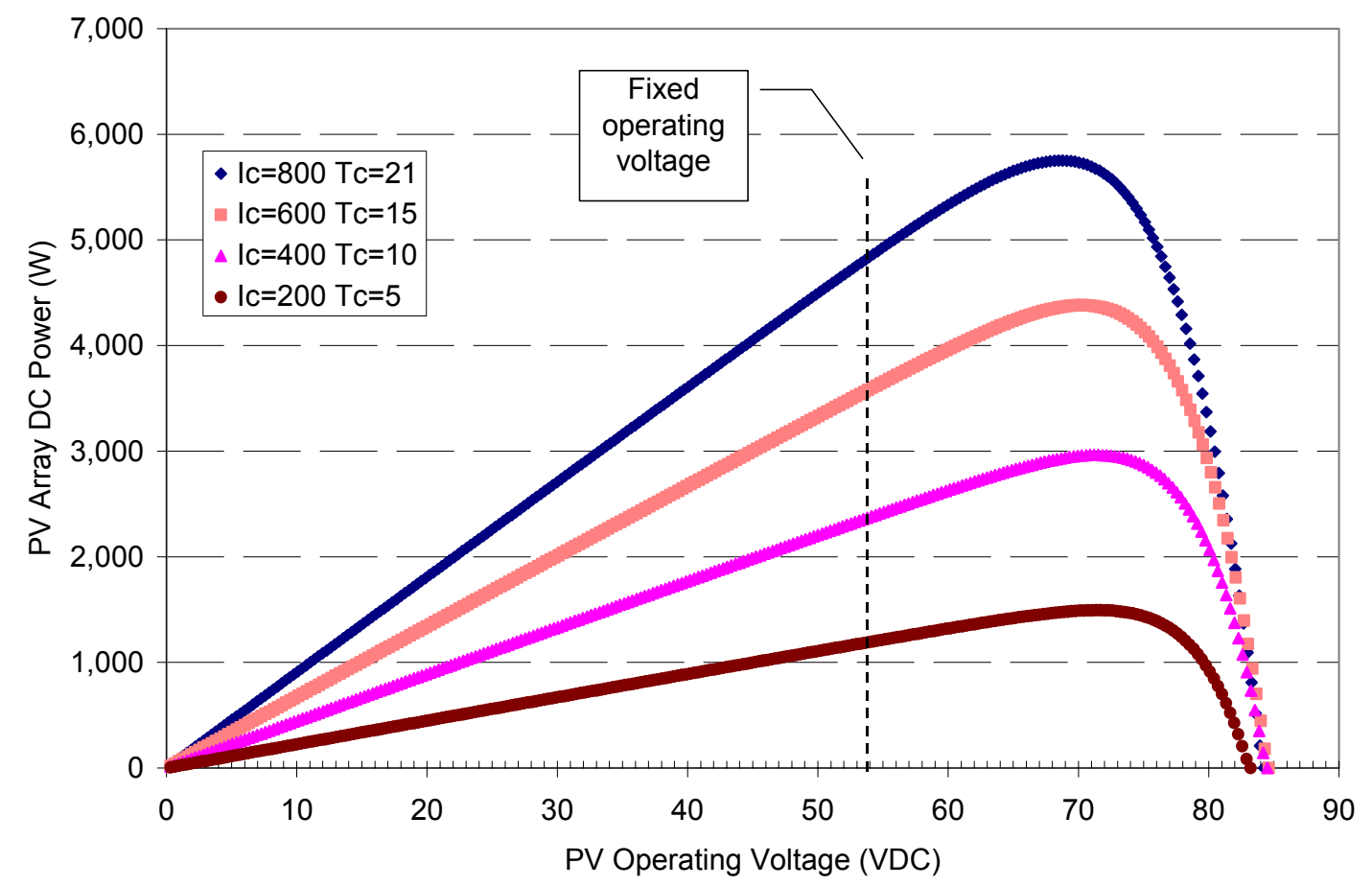

Figure 6-18 Simulated power-voltage curve traces for winter weather conditions

Also simulated for voltage control was the optimal fixed voltage. The annual PV production is optimized at a fixed voltage of $61 \mathrm{VDC}$, as shown in Figure 6-19. Although this operating voltage results in the optimal annual PV production, it is not practical for charging the nominal 48 VDC battery backup system.

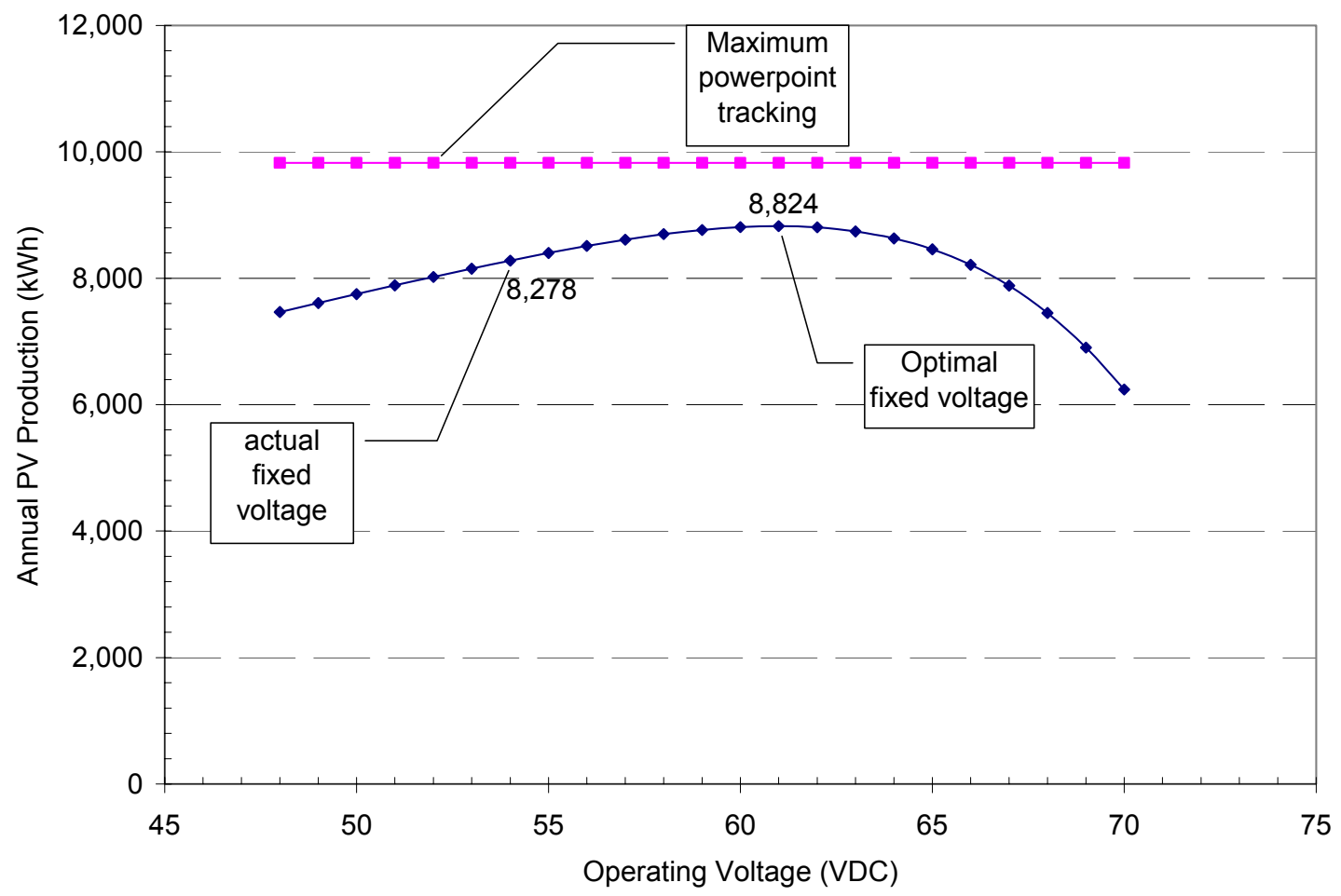

Figure 6-19 Simulated annual PV production: Best fixed voltage, actual fixed voltage, and maximum power-point tracking 
The annual performance is degraded by $7 \%$ because of the tree that partially shades the west set of modules late in the afternoon. While the measured PV system production is expected and all system losses accounted for, the net annual production could be increased with a maximum power-point tracker. A maximum power-point tracking voltage controller would increase typical performance by $16 \%$ as compared to the fixed operating voltage control of 53.6 VDC. Unfortunately, the inverter will not allow maximum power-point tracking. Figure 6-20 provides a comparison of the annual PV production for the shading models, maximum power-point control model, and measured insolation model using the TMY2 data to the measured performance. Table 6-4 shows the performance degradation results for the PV system and the estimated impact on actual PV production.

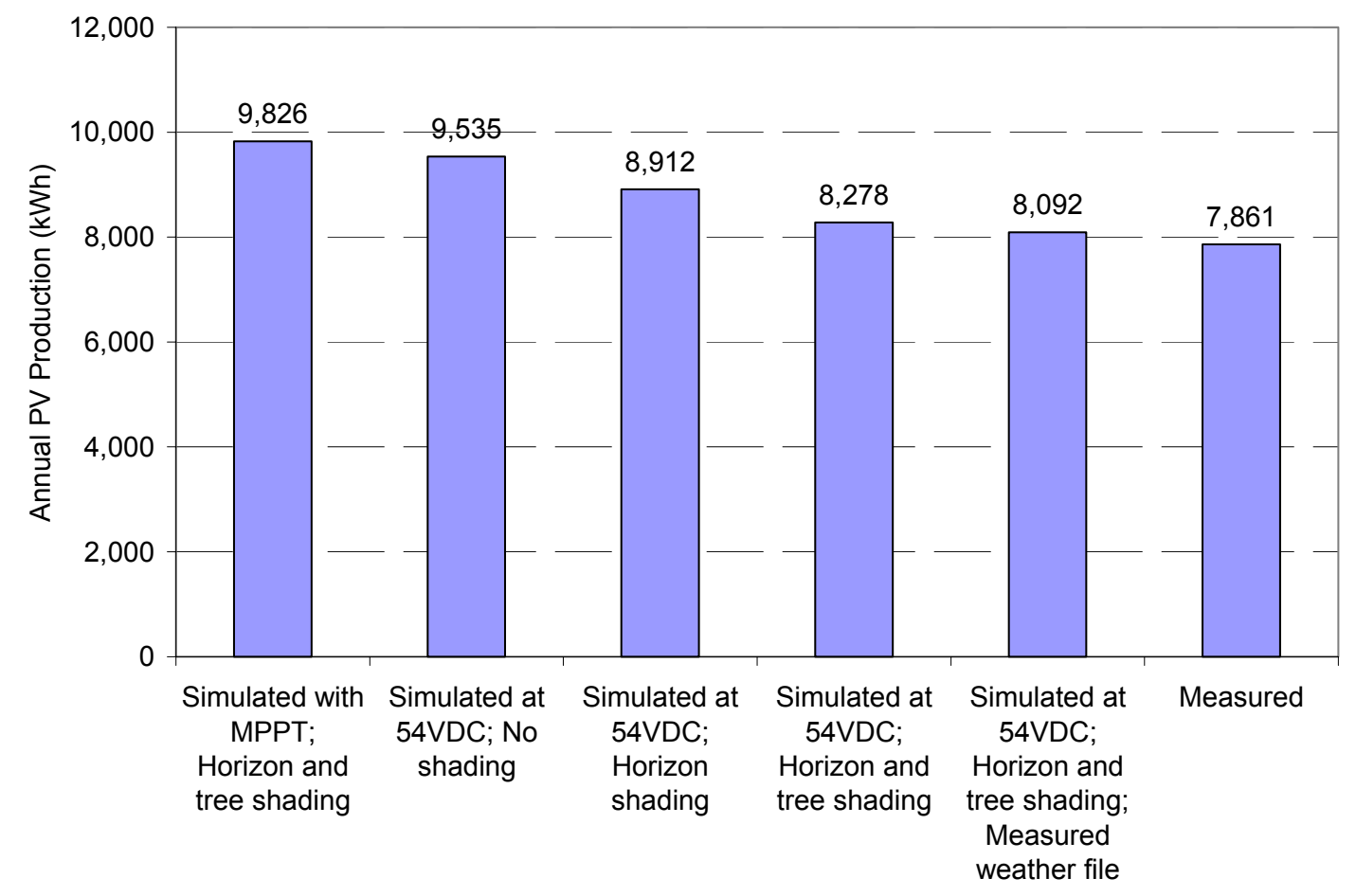

Figure 6-20 Simulated annual PV production comparisons to measured PV production

Table 6-4 Performance Degradation Results

\begin{tabular}{|l|c|c|}
\hline \multicolumn{1}{|c|}{ Type of Fault } & $\begin{array}{c}\text { Estimated PV } \\
\text { Production Lost } \\
\mathbf{( k W h )}\end{array}$ & $\begin{array}{c}\text { Percent of Total } \\
\text { Measured PV } \\
\text { Production }\end{array}$ \\
\hline Horizon Shading (Canyon Walls) & 623 & $7.9 \%$ \\
\hline Tree Shading & 634 & $8.1 \%$ \\
\hline $\begin{array}{l}\text { Unknown (Maintenance, Battery inefficiency, } \\
\text { modeling and measurement uncertainty) }\end{array}$ & 221 & $2.8 \%$ \\
\hline
\end{tabular}

\subsubsection{PV UPS and Simulated Failure}

The UPS circuit allows the building to remain operational during daylight hours when no power is available. The UPS powers the computer equipment, cash registers, window actuators, cooltower pumps, telephone switch, and BAS. The UPS system contains 200 Ah of battery capacity. 
The poor power quality from thunderstorms causes the power to cycle off and on through many sequences in a short time period. For example, brownouts occurred several times on the day before the test day. During a power outage, the inverter would maintain the $1800-\mathrm{W}$ emergency panel load and would drain the batteries within a few hours. At this point, the low-battery alarm point would trigger, but there was a 15-minute delay before the loads were disconnected and the inverter shut down. It appears that during this time, the batteries continued to drain and the output voltage from the inverter was not stable. The result was partial loss of memory from the BAS. The BAS is critical to operation of all systems including lights and HVAC. The Comfort Station BAS panel did not experience any loss of memory because of clean power disconnect and reconnect.

On the evening of August 18, 2001, we performed a power failure test on the emergency power system at the Visitor Center. Because only the inverter system was being tested, the test was performed by setting the main PV-utility disconnect to OFF. This disconnected the inverter system from the main distribution panel. A power meter was attached to panel "E."

The settings on the inverter were adjusted to disconnect and provide UPS power when the grid voltage drops below $110 \mathrm{~V}$ and will shutdown the inverter when the batteries drop below $46.0 \mathrm{~V}$. The inverter will not delay after this low battery cut-off. In addition, a low-battery warning signal was set to trigger at a battery voltage of $46.6 \mathrm{~V}$ and below. From this test, the BAS panel in the Visitor Center on the UPS completely shutdown and recovered when power was restored to the system.

The grid power was disconnected at 8:01:32 p.m. At 9:46:57 p.m., the inverter shut off, resulting in no emergency power. This time was 1:45:27 hours after the utility failure. During unoccupied hours, or when no solar radiation is available, this is enough time to operate the building and plan for an organized shutdown of computer equipment. Power was restored at approximately 10:18 p.m. The inverter started a few seconds later (10:18:06 p.m.) and restored power to the emergency panel. At 10:26:10 p.m., the pumps in the cooltowers were energized by the BAS. This equipment is on a delay start to prevent surges on power restoration. These pumps cycle on start-up, as needed, to provide water to the pads, resulting in fluctuations in power consumption. The total energy delivered by the UPS during power outage was $3.028 \mathrm{kWh}$. Results from this test are shown in Figure 6-21. It is interesting to note the pattern of the voltage provided by the inverter and the variation of the utility power after the power was restored. 


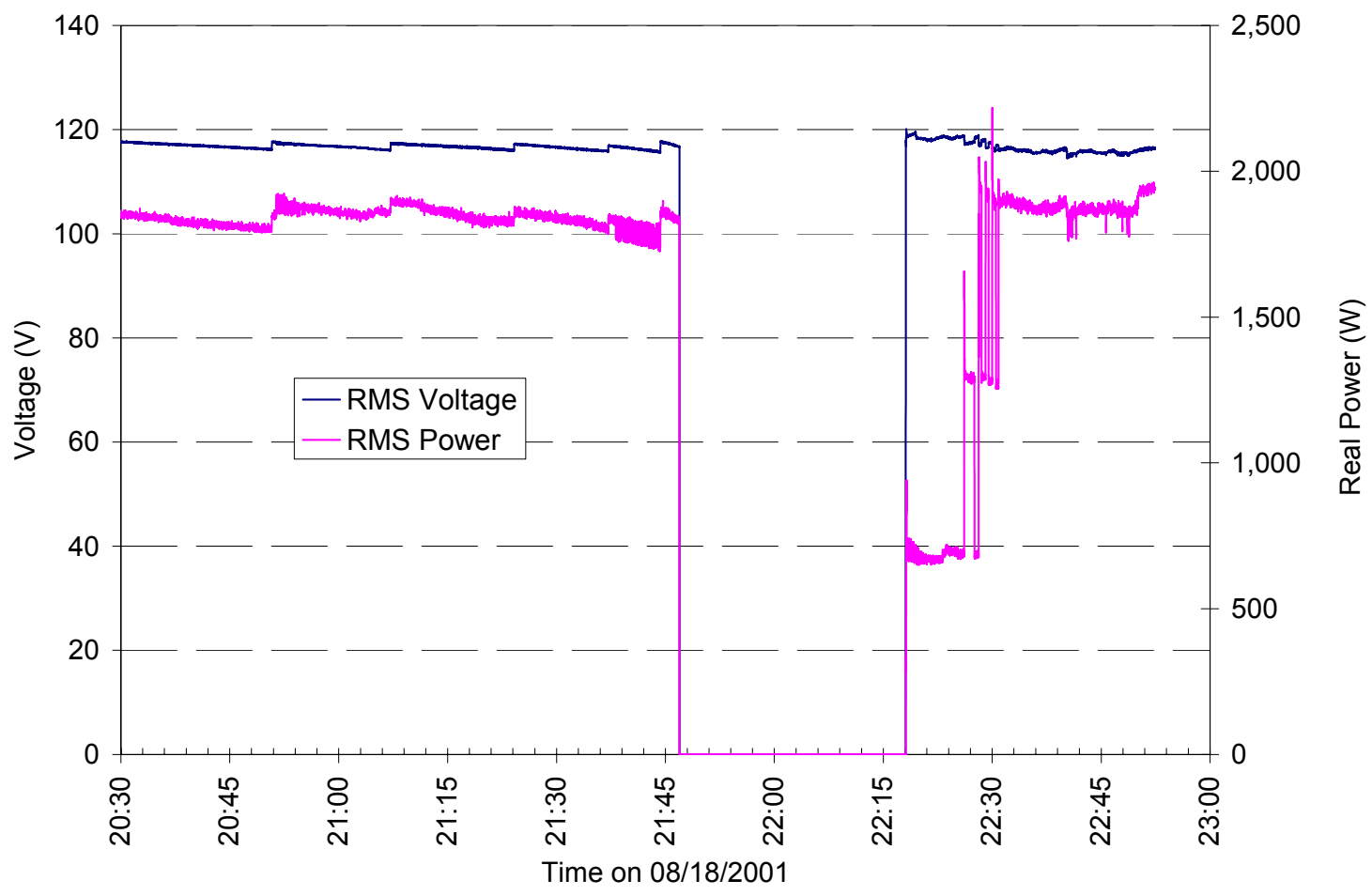

Figure 6-21 Voltage and real power of emergency panel versus time for a utility grid power outage

During February 2001 through May 2002, the building power was monitored to further verify the operation of the UPS system. Because of the unreliable power in the area, the power shut off many times. A couple of times, the UPS system was unable to maintain clean power. During the evaluation period, the grid disconnected 50 times for more than 0.5 seconds. If the grid shut down for less than 0.5 seconds, the scan rate on the BAS did not record the power failure. We believed that the panel had many split second disturbances, but it was unable to record the instances. The total time the grid was unavailable and the UPS system was functional during the evaluation period was 107.4 hours or $2.6 \%$ of the time. The UPS maintained power to the building and the BAS during all of these instances except two.

The frequent outages are normally a quick disconnect and reconnect. For instance, on March 1, 2002, the power turned off and on 10 times in a 30-minute period with a typical outage ranging from 0.5 seconds to 15 seconds. The power may have actually fluctuated more, but the resolution of the data logger was only 0.5 seconds. The reason the UPS system did not catch a couple of the failures is still unknown. In these instances, the power was disconnected to the "E" panel for less than 0.5 seconds before battery power would be fed into the inverter.

\subsection{Lighting and Daylighting Evaluation}

\subsubsection{Lighting and Daylighting Evaluation Methods}

The evaluation team performed the measurement segment of the Visitor Center daylighting analysis based on a monitoring protocol developed by the International Energy Agency Solar Heating and Cooling Programme (IEA/SHC) Task 21 (Atif 1997). This protocol offers guidelines for measuring daylighting performance, predicting performance, and evaluating control parameters. The performance measurement section of this protocol outlines recommended techniques for monitoring the daylighting contribution to 
indoor illuminance and the corresponding electrical lighting displacement. These techniques include measurement of horizontal illuminance in selected daylit zones during varying sky conditions for typical summer, winter, and fall/spring seasons. Recommended illuminance levels for each lighting zone were analyzed in accordance with the Lighting Handbook of the Illuminating Engineering Society of North America (IESNA 2000). Simultaneous monitoring of external horizontal illuminance and electrical lighting consumption are required to complete the daylighting measurements.

The goals of the daylighting evaluation were to:

- determine the amount of electrical lighting offset by lighting design and daylighting when compared to a base case,

- analyze the operation of lighting and daylighting controls and optimize their performance,

- quantitatively and qualitatively assess the daylighting design, and

- document successes and weaknesses of using daylighting as part of the lighting system.

In accordance with the IEA/SHC Task 21 daylighting monitoring standards, we made short-term continuous measurements of illuminance at varying sky conditions for different seasons. These continuous measurements were performed in the ZNHA (Zion Natural History Association) bookstore area. The locations of illuminance measurements are shown in Figure 6-22. Illuminance was measured for 12 points on the top of the bookshelves at a height of $6 \mathrm{ft}(1.82 \mathrm{~m})$. Measurements were taken at 5second intervals and recorded as 5-minute averages. In addition, we also measured the outdoor illuminance (location 13).

Because the protocol specifies that measurements be taken within 3 weeks of the beginning of each season, illuminance measurements were taken near the summer solstice (July 11-12, 2000), the fall equinox (September 20-22, 2000), and the winter solstice (December 14-16, 2000). The electric lights operated in the as-designed control scheme.

In addition to continuous measurements, handheld measurements were made on a $10-\mathrm{ft}(1.82 \mathrm{~m})$ grid at a height of 48 in. $(121.9 \mathrm{~cm})$ over the interior of the Visitor Center. The locations of the handheld measurements are shown in Figure 6-22. The primary purpose for the handheld illuminance measurements was to determine discrete illuminance levels in lighting zones not considered by the continuous measurement system. The measurements were taken for varying sky conditions and times of day.

The BAS measured electric lighting consumption from August 2000 to July 2003. The measured lighting energy consumption included all area and display lighting electricity used in the building and in the adjacent parking lot and sidewalks. End-use categories were measured as outdoor BAS controlled parking lot lights, indoor switch or motion controlled lights, and indoor BAS controlled space lights. The Comfort Station BAS controlled lighting consumption was measured as well, although a full daylighting analysis was not conducted in this building. 


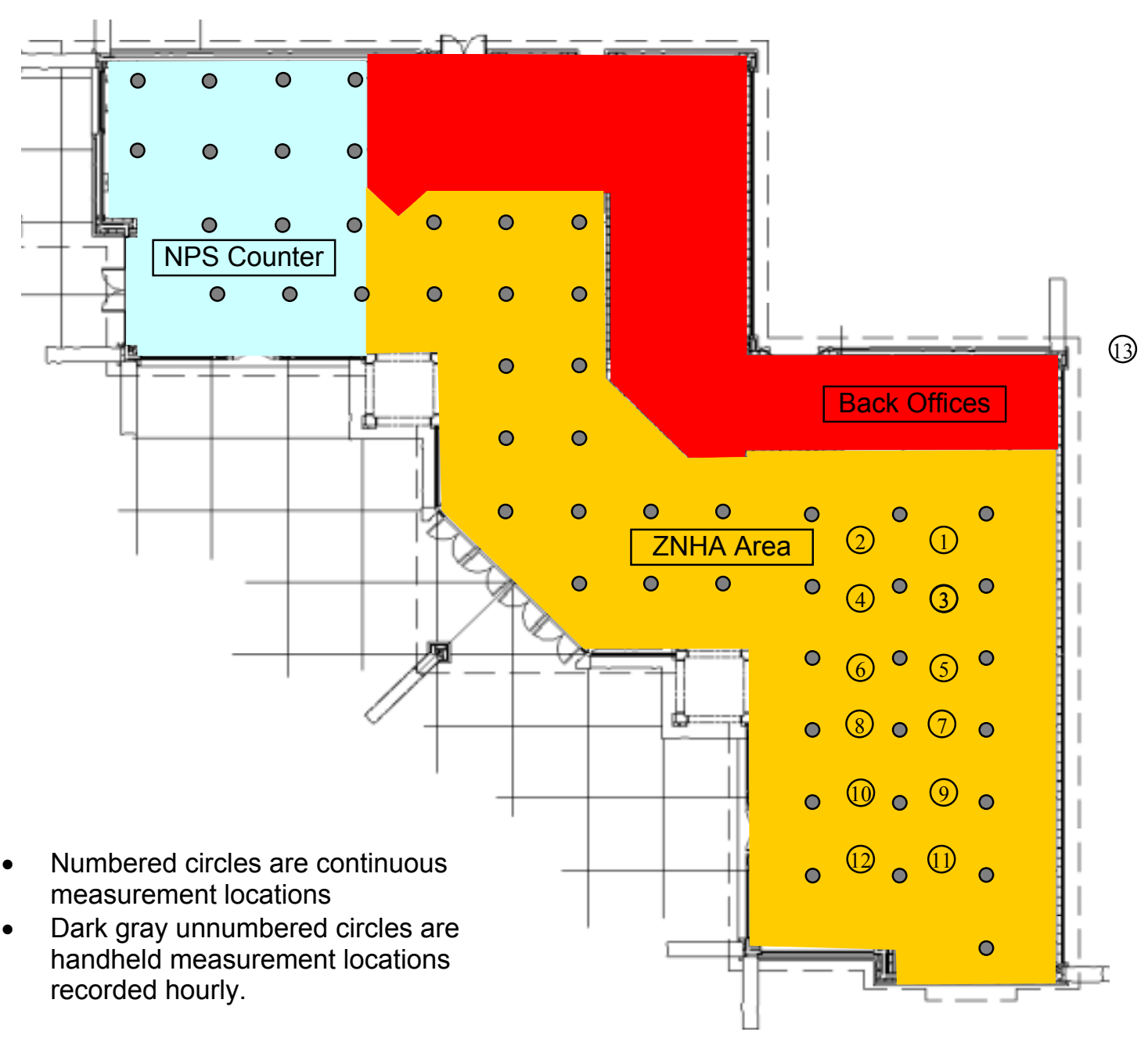

Figure 6-22 Continuous and handheld illuminance measurement locations

\subsubsection{Lighting and Daylighting Evaluation Results}

A principal metric in the evaluation of the lighting and daylighting systems is the energy consumption of these systems. The total installed interior and exterior lighting was responsible for $31 \%$ of the total site load, and consumed $28,957 \mathrm{kWh}$, or $8.4 \mathrm{kBtu} / \mathrm{ft}^{2} \cdot \mathrm{yr}\left(95 \mathrm{MJ} / \mathrm{m}^{2} \cdot \mathrm{yr}\right)$. The outdoor and parking lot lights were responsible for $10 \%$ of the total lighting load for the site. These lights were in operation from dusk until 11:30 p.m. and from 5:30 a.m. to dawn. The building lighting end uses (Comfort Station and Visitor Center computer controlled, and Visitor Center switch controlled) used $26,157 \mathrm{kWh}$ or $7.6 \mathrm{kBtu} / \mathrm{ft}^{2} \cdot \mathrm{yr}(86$ $\mathrm{MJ} / \mathrm{m}^{2} \cdot \mathrm{yr}$ ). In comparison, according to the CBECS database, the average lighting energy intensity for mercantile and service buildings was $23.4 \mathrm{kBtu} / \mathrm{ft}^{2} \cdot \mathrm{yr}\left(266 \mathrm{MJ} / \mathrm{m}^{2} \cdot \mathrm{yr}\right)$, or $67 \%$ more than the measured lighting consumption. As a general lighting performance metric, this indicates high-performance lighting and daylighting design and operation.

\subsubsection{Calculated Energy Savings Resulting from Lighting and Daylighting Design}

To quantify the success of Zion's lighting design coupled with daylighting, the evaluation team considered the conventional base-case building (the same base case discussed in previous sections). The base-case model predicts the indoor and outdoor lighting end use consumption in a conventional nondaylit building according to the Federal Energy Code 10 CFR 435. This code outlines upper limits for 
lighting power densities (LPD) ${ }^{4}$ by zone type for federal buildings. The base case predicted that a conventional retail and display building would consume $107,781 \mathrm{kWh}$ annually, or $31.4 \mathrm{kBtu} / \mathrm{ft}^{2} \cdot \mathrm{yr}(357$ $\mathrm{MJ} / \mathrm{m}^{2} \cdot \mathrm{yr}$ ), of total indoor and display lighting electricity. Every attempt was made to schedule the lights in the base case to estimate what the lighting load would have been without daylighting and occupancy controls, and with typical manual control. Atypical occupancy and manual control can provide a source of error in comparing measured lighting consumption to the simulated base case.

Because the total lighting load for the base case and the actual building included $400 \mathrm{~W}$ of parking lot lighting not directly related to either building, the lighting savings without including the parking lot lights become relevant. In this case, the base case predicted that a conventional building would consume $104,981 \mathrm{kWh}$ in building-related lighting electricity. Compared to the measured indoor building annual lighting electricity consumption of $26,157 \mathrm{kWh}$, the building lighting loads were $75 \%$ less than a conventional building. These lighting consumption savings are attributed to improved lighting and daylighting design and operation, as ZNP incorporates a reduced LPD and daylighting design strategies with occupancy controls that are not included in the conventional base-case simulation.

To investigate the savings from the reduced LPD, the evaluation team compared the base-case model, which included the LPD shown in Table 6-5, to a base-case model using the actual LPD. The only difference between the actual LPD base-case model and the code-compliant, base-case model was the difference in LPD as shown in Table 6-5.

Table 6-5 Base-Case and Actual Lighting Power Density by Space

\begin{tabular}{|l|c|c|c|}
\hline \multicolumn{1}{|c|}{ Zone } & $\begin{array}{c}\text { Base-Case LPD } \\
\mathrm{W} / \mathrm{ft}^{2}\left(\mathrm{~W} / \mathrm{m}^{2}\right)\end{array}$ & $\begin{array}{c}\text { Actual LPD } \\
\mathrm{W} / \mathrm{ft}^{2}\left(\mathrm{~W} / \mathrm{m}^{2}\right)\end{array}$ & $\begin{array}{c}\text { Percent } \\
\text { Reduction }\end{array}$ \\
\hline \hline Offices & $\begin{array}{c}1.4 \\
(15)\end{array}$ & $\begin{array}{c}0.96 \\
(10)\end{array}$ & $31.4 \%$ \\
\hline Retail and Display & $\begin{array}{c}2.2 \\
(24)\end{array}$ & $\begin{array}{c}0.90 \\
(9.7)\end{array}$ & $59.1 \%$ \\
\hline Comfort Station & $\begin{array}{c}1.0 \\
(11)\end{array}$ & $\begin{array}{c}1.00 \\
(10.8)\end{array}$ & $0.0 \%$ \\
\hline Outdoor and Parking Lot & $400 \mathrm{~W}$ & $400 \mathrm{~W}$ & $0.0 \%$ \\
\hline
\end{tabular}

When the actual LPD base-case model was simulated with the reduced LPD, the annual indoor lighting consumption was $52,130 \mathrm{kWh}$, which was $50 \%$ less than the code-compliant, base-case lighting upper limit. The reduced LPD resulted in the 50\% lighting energy savings. The installed LPD is not as high as 10 CFR 435 recommends because the lighting design accounts for a daylighting contribution during the day, includes efficient fluorescent lamps and ballast, and appropriate placement of task lighting. Nighttime illuminance levels can be a concern when the installed LPD is lower than the recommended levels, as the daylighting contribution is not available. To ensure that the LPD was not too low, the evaluators measured the quality of lighting and daylighting, which is discussed in the following sections and in Appendix F.

A second type of lighting energy savings can be attributed to appropriate control of the installed luminaire. The Visitor Center and Comfort Station lighting control strategy involves multiple daylighting sensors combined with motion controlled switches. To evaluate the savings that accrue from the daylighting and occupancy control strategies, the measured building-related lighting consumption was compared to the base-case model with the actual LPD and no occupancy sensors or daylighting. The measured building lighting consumption was 50\% less than the predicted actual LPD base case, as shown in Figure 6-23. NREL expected that occupancy sensors combined with daylighting controls would result in the displacement of $52,314 \mathrm{kWh}$ of electrical lighting.

\footnotetext{
${ }^{4}$ LPD refers to the installed lighting power per $\mathrm{ft}^{2}\left(\mathrm{~m}^{2}\right)$.
} 
Daily profiles of lighting consumption averaged over the year for the code-compliant base case, the actual LPD base case, and the measured consumption are shown in Figure 6-24. The $2.5 \mathrm{~kW}$ difference in peak morning consumption between the actual LPD base case and the measured lighting consumption is due to occupancy sensors only operating lights in occupied zones.



Figure 6-23 Lighting and daylighting design savings for indoor lighting 




Figure 6-24 Measured, base case, and actual LPD annual lighting consumption profiles and savings (October 2001 to November 2002)

\subsubsection{Lighting and Daylighting Quality and Quantity}

The results of the continuous indoor retail and outdoor illuminance levels are shown in Figure 6-25 for typical days in each of the prescribed measurement periods. The south retail illuminance measurement is an average of measurement points in the bookstore next to the Trombe wall, while the north retail illuminance measurement is an average of the retail measurement points directly under the clerestory, as shown in Figure 6-22. As shown in the September and December measurements, the electrical lights are turned on for the cleaning staff at 6:00 a.m. As the outdoor illuminance levels increase, additional daylighting is provided to the space. Note that the daylighting contribution to the retail illuminance levels is greater in the winter than the summer, even with lower available outdoor illuminance. This difference is because the lower solar altitude angle in the winter results in better daylighting penetration into the retail area. Although not shown in Figure 6-25, direct solar penetration does result in glare during the fall and winter examples, which is not evident because the location of the continuous illuminance measurements. The overhang design typically blocks direct beam from entering the space in the summer, although early morning and late afternoon glare has been a problem. The early morning glare issue was due to the east clerestory windows. 


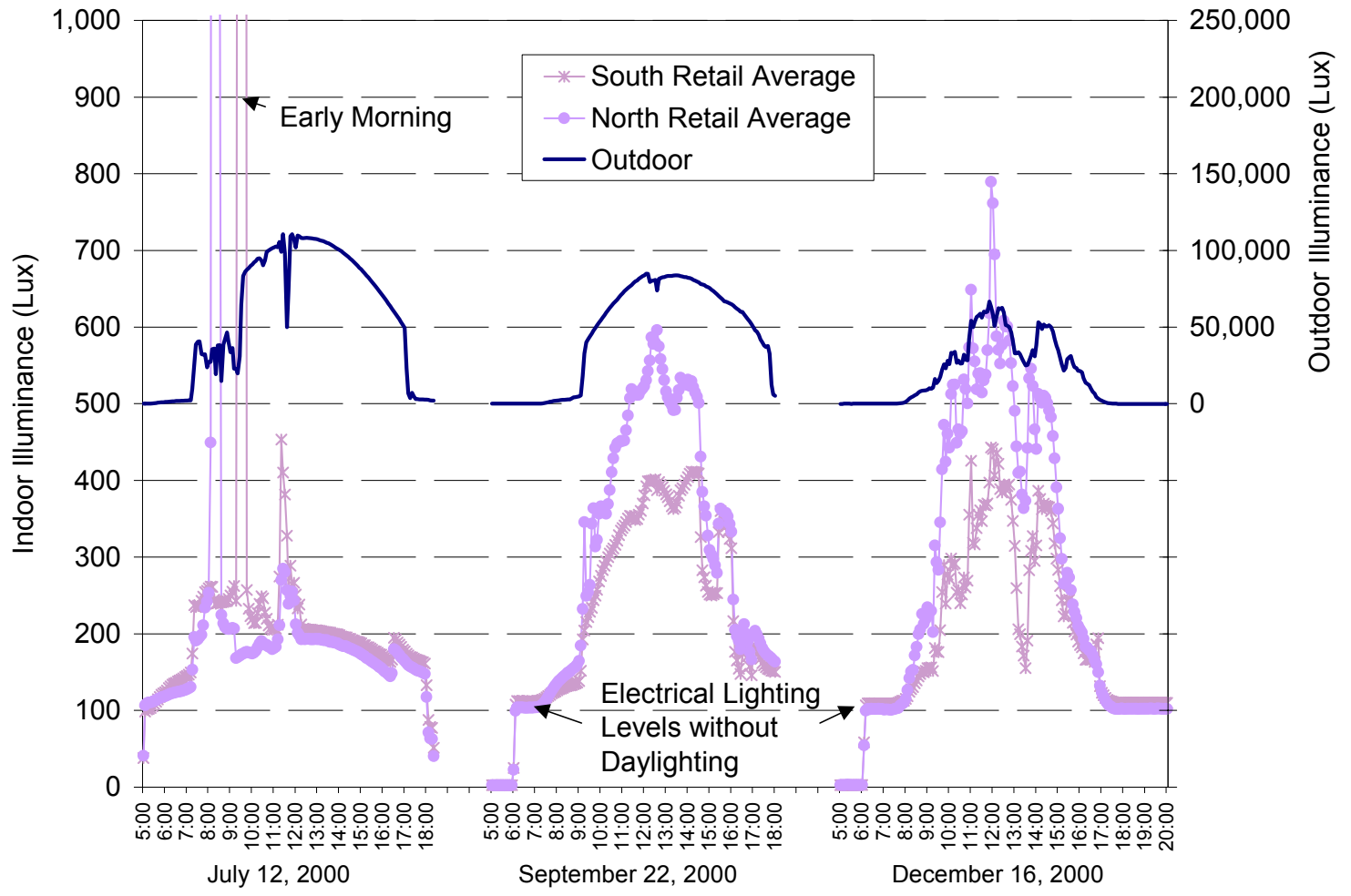

Figure 6-25 Measured bookstore and outdoor illuminance levels, July 12, 2000; September 22, 2000; and December 16, 2000

Examples of this glare problem are shown in Figure 6-26 and Figure 6-27. The first glare example shows excessive glare on the bookstore checkout counter and staff during an early morning in December. This was from direct solar gain through the clerestories. Due to the poor placement of the checkout stands with relation to direct solar gain, glare can overwhelm staff and customers. In the rest of the areas, direct solar gain and the resulting glare is not a problem. Occupants are not focused on a single area and any glare issues are compensated by occupant behavior (moving in/out of glare if it is a problem). Note that the location of the checkouts was not determined until just before occupancy, so provisions could not be made during the design phase. Glare and direct gain is acceptable in this space as long as people can control their location with respect to the glare. When the checkout counter glare was identified as a problem, direct solar gain through the clerestory was controlled using diffusing film placed on the clerestory glass. The diffusing film eliminated direct gain and the resulting glare.

The second glare example, Figure 6-27, shows excessive direct solar gain in the southeast office on a December afternoon. This glare is the result of direct gain through the unshaded southern windows above the Trombe wall. The occupants typically utilize a temporary shading device (cardboard) when the glare is a problem. Adjustable blinds or diffusing film would provide a permanent glare management solution. 




Figure 6-26 NPS bookstore checkout counter glare from clerestories

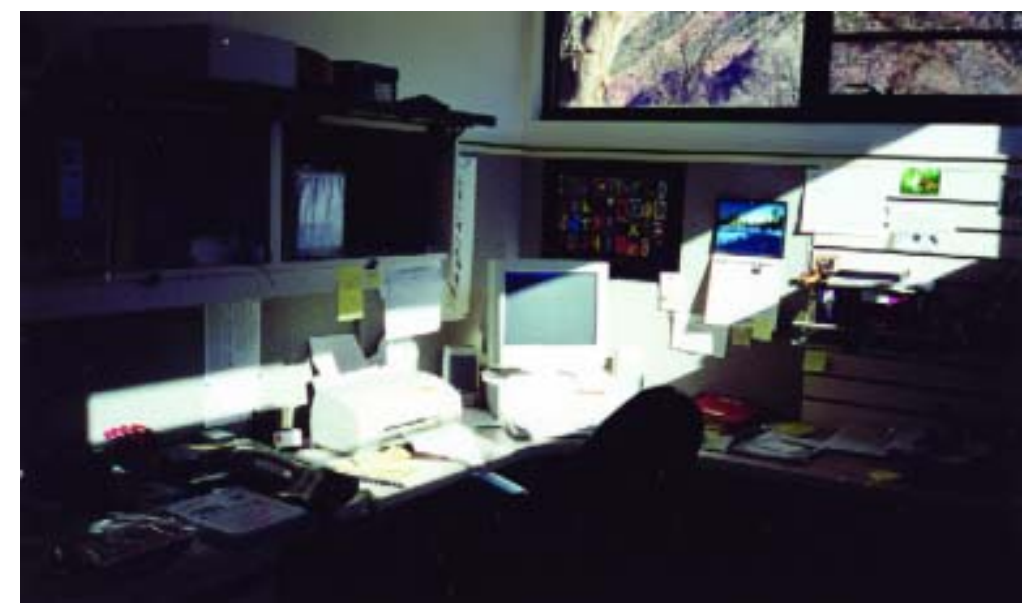

Figure 6-27 Southeast office afternoon glare

Figure 6-25 also shows illuminance measurements without a daylighting contribution. Nighttime illuminance levels at the continuous measurement location points in the bookstore are about 100 Lux. Figure 6-28 shows nighttime illuminance levels over the Visitor Center, taken from handheld illuminance measurements. 


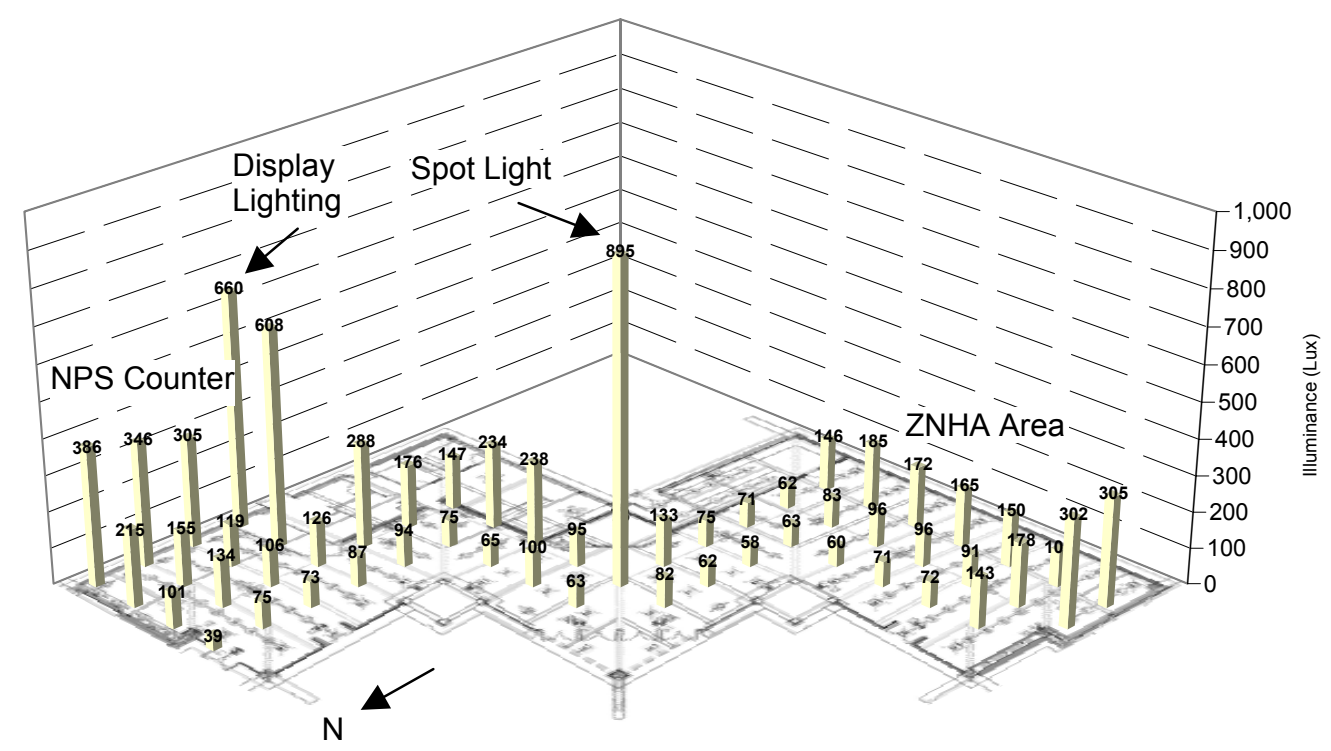

Figure 6-28 Illuminance points over the floor plan from electrical lights without daylighting on July 10, 2000, 10:00 p.m.

The $0.9 \mathrm{~W} / \mathrm{ft}^{2}\left(9.9 \mathrm{~W} / \mathrm{m}^{2}\right)$ of installed electrical lighting in the retail area results in nighttime illuminance levels as shown in Figure 6-28. Low nighttime illuminance levels in the circulation spaces and in the retail spaces are evident. Areas directly under spotlights or display lighting are uncharacteristically higher than the general space lighting levels. The measured nighttime illuminance levels with all the lights on are lower than expected at $0.9 \mathrm{~W} / \mathrm{ft}^{2}\left(9.9 \mathrm{~W} / \mathrm{m}^{2}\right)$. The Illuminating Engineering Society of North America recommends luminance levels of 500 Lux in retail spaces (IESNA 2000). A primary reason for low nighttime illuminance levels is due to the uplighting design combined with tall, dark ceilings. The space lighting fixtures provide $88 \%$ uplighting, which is absorbed in the ceiling and dark beams, and limited amounts are reflected back to the space.

The dark structural beams throughout the buildings were not considered when the daylighting features were designed. The dark beams absorb and block significant portions of the clerestory daylighting. This problem was identified during construction based on the proposed colors of the wood and the ceiling. The uplighting design and the daylighting would have functioned better if the ceilings had been a brighter color or a higher percentage of the light came from downlighting.

The Visitor Center does not have visitors at night, so low electrical illuminance levels are adequate in this case. No complaints have been received for low light levels in the evening partly because of the contrast from the dark exterior to the interior of the building. People have adjusted to darker ambient conditions and seem to accept lower interior ambient levels. During the day, complaints have been received from bookstore staff as to the level of the lighting. This is in part due to the high exterior ambient lighting compared with inside. Part of the original intent was to use lower lighting levels in the building to make the space feel cooler compared to the bright, hot exterior.

A sample of the quantity of daylighting under typical operation for a summer and winter period is shown in Figure 6-29 and Figure 6-30. Similar graphs of the illuminance levels due to daylighting with the lights turned off are included in Appendix F. Again, note the additional daylighting contribution in the winter months. The low illuminance levels in the summer led to installation of task lighting not connected to the daylighting controls, as illuminance levels were not adequate for detailed task work at the checkout stations. Task lighting in the form of linear T-5's were installed over the cash register counters and the interpretation desks. This solution greatly reduced the issues of lower illuminance in the remainder of the space. The lighting levels in the bookstore were less than predicted because of reasons 
that were previously discussed. With additional task lighting, the low illuminance levels do seem to be adequate for this type of retail environment when augmented by the daylighting and appropriately located task lighting. The addition of these task lights significantly reduced the lighting issues.

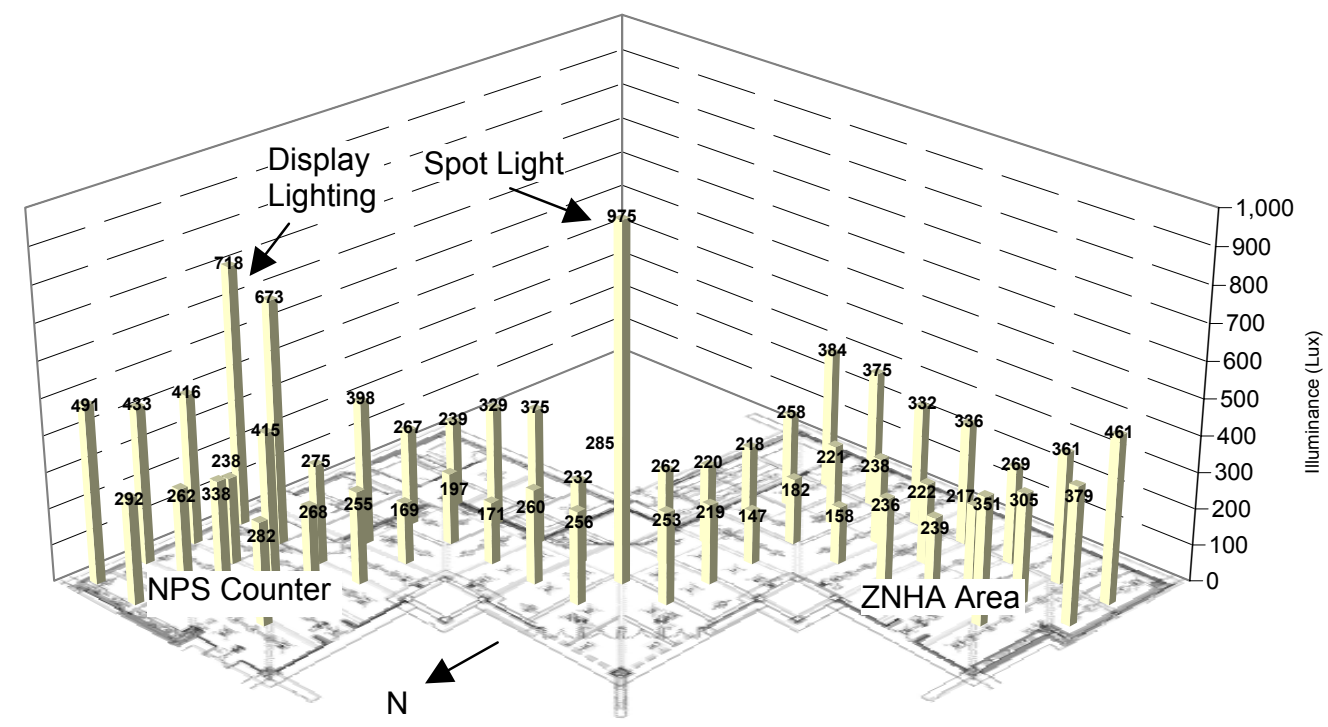

Figure 6-29 Illuminance points across floor plan for a clear sky with lights on; July 11,2000 at 12:25 p.m.

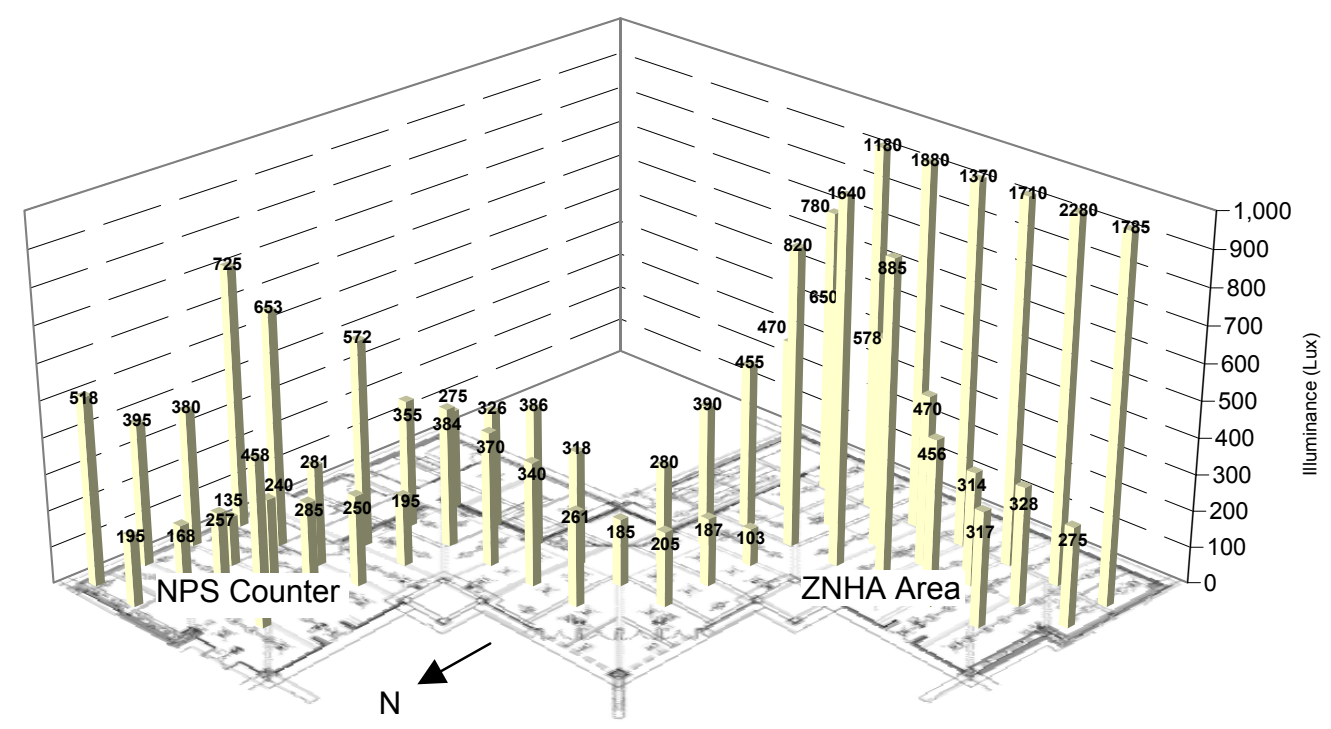

Figure 6-30 Illuminance points across floor plan for a partly cloudy sky with lights on as normal; December 14, 2000 at 12:15 p.m.

The original daylighting analysis for the proposed building intended to have many more lights off, with daylighting significantly reducing the electrical lighting load. Although daylighting has reduced the lighting consumption compared to typical buildings that are not daylit, the success of the daylighting at Zion has been restricted due to several issues in the building's design and implementation. Issues include the following:

- The size of the specified clerestory visible glazing was not adequately communicated to the design team, reducing the daylighting from the clerestories. The frames, mullions, screens, and automation 
mechanisms all reduce the amount of visible glazing in the clerestory windows and were not considered in the original daylighting design. This reduced the expected daylighting provided by the clerestories from the original design. It is important to specify the visible window area when transferring information from the energy consultant to the design team. It is also important to understand the impact of screens.

- The dark structural beams throughout the buildings were not considered when the daylighting features were designed. These dark beams absorb and block significant portions of the clerestory daylighting and uplighting. (Daylighting is more effective with white ceilings.)

- Stepped lighting controls work well as long as they are not in an area where detail work is occurring. Continuous task lighting would offset the on/off sequencing of the lights and provide additional lighting at critical locations. The stepped daylighting controls have been problematic, as the stepped control resulted in uneven distribution and occupant complaints of on-off sequencing. The design of the stepped operation called for every other fixture to be on a separate circuit. What was installed was every other row on a separate circuit, which resulted in uneven distribution during stepped control operation. Continuously dimming fixtures would allow for even distribution of the electric lights, resulting in further reduction of lighting consumption.

Continuous monitoring of the lighting and daylighting systems have identified and addressed several problems. Clerestory glare problems were addressed with diffusing films, and adjustable blinds recommended for occasional glare in the offices. We added additional task lighting in critical areas, as the stepped controls, uplighting, and daylighting did not provide adequate illuminance levels for detailed work. Appropriate placement and use of occupant controlled task lighting is essential for daylit buildings with reduced LPD, especially for detailed task work.

\subsection{Comfort Evaluation}

\subsubsection{Comfort Monitoring Methods}

A comfort analysis was performed to determine the ability of the energy-efficient heating and cooling systems to provide adequate comfort to building occupants. Ultimately, an energy-efficient HVAC system should maintain occupant comfort while minimizing energy costs. The Visitor Center and Comfort Station are monitored and controlled separately. Temperature measurement points in the Visitor Center consist of twelve temperature sensors located on the walls and three sensors located on the ceiling. Layout of the temperature sensors can be seen in Figure 6-31. The Visitor Center is organized in three main zones: the ZNHA Office, the NPS Counter, and the Back Offices. The BAS calculates the average temperature of these three zones and records the values. The BAS controls the spaces based on these temperatures. The Comfort Station has six temperature sensors total. The BAS averages all values in the Comfort Station and determines the appropriate actions needed to maintain comfort. 


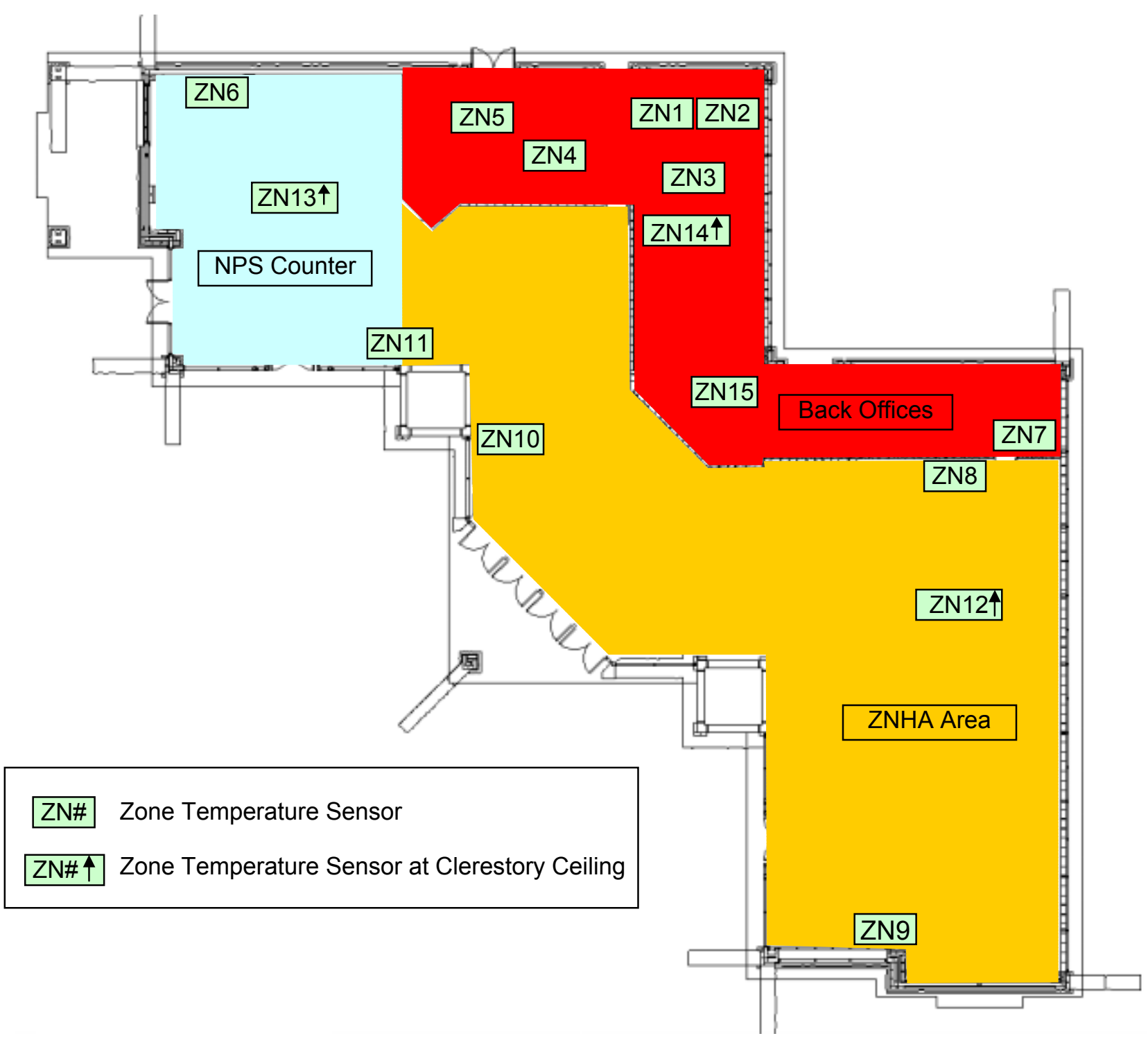

Figure 6-31 Layout of temperature sensors for Visitor Center

For the comfort analysis, the Visitor Center was categorized into three different areas the ZNHA Area, NPS Counter, and the Back Offices. The zones for the areas are listed in Table 6-6.

Table 6-6 Visitor Center Area Definitions

\begin{tabular}{|c|c|}
\hline Area & Zone Temperature Sensor \\
\hline \hline ZNHA Area & $8,9,10,11,12$ \\
\hline NPS Counter & 6,13 \\
\hline Back Offices & $1,2,3,4,5,7,14,15$ \\
\hline
\end{tabular}

For the analysis, the winter was defined as October 1 through April 30, while summer was from May 1 through September 30. The occupied hours were defined from 8 a.m. to 5 p.m.

\subsubsection{Comfort Monitoring Results}

The outdoor temperatures for the winter of 2002-2003 were slightly higher than the temperatures for the winter of 2001-2002 (Section 6). In general, during the winter, the occupants were considered 
comfortable because the occupants had control of the heating set point up to $74^{\circ} \mathrm{F}\left(23.3^{\circ} \mathrm{C}\right)$. During 2002-2003, the temperatures were slightly cooler indoors partially due to a lower heating set point. Figure 6-32 shows the hours at the given temperature for the average Visitor Center temperature.

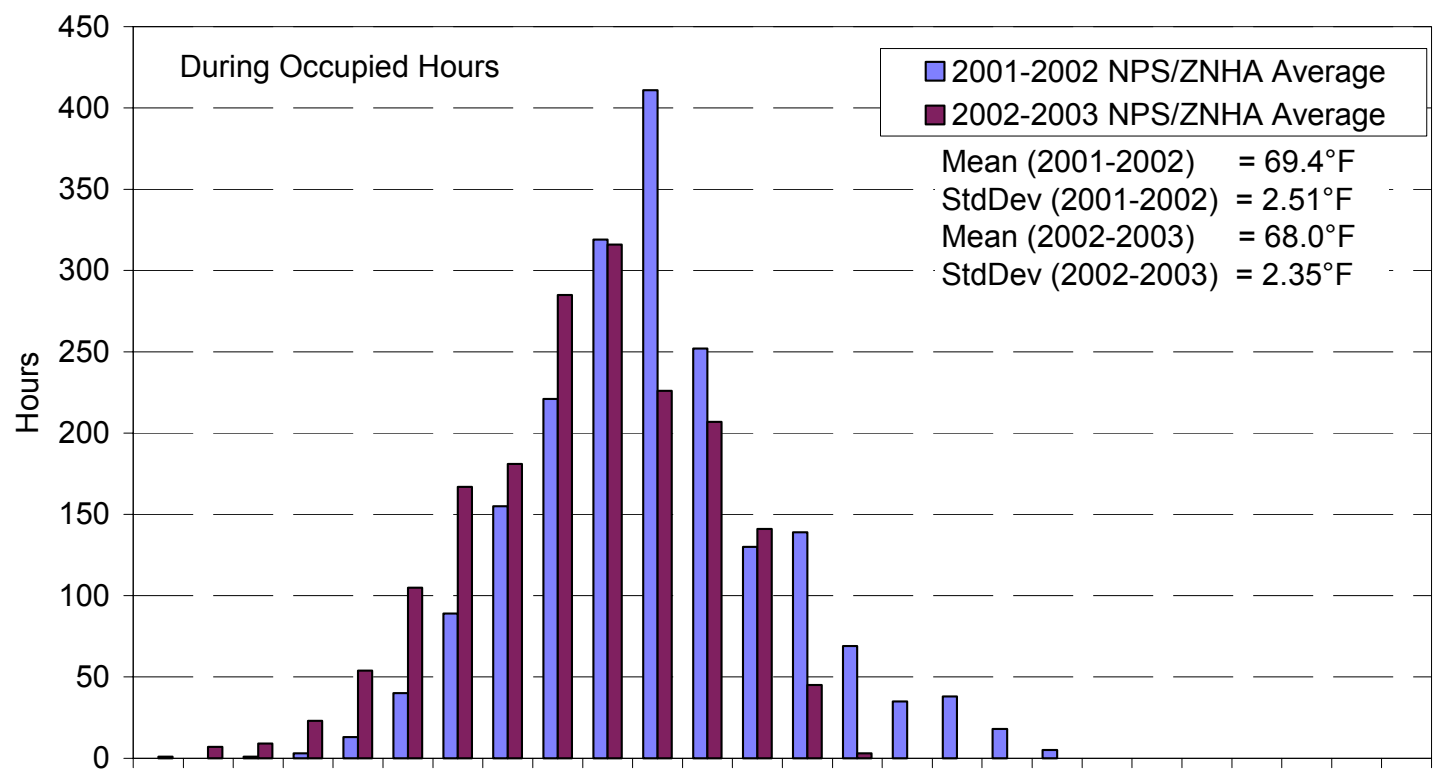

$60 \quad 616263 \quad 64 \quad 6566 \quad 67 \quad 68 \quad 6970717273 \quad 7475 \quad 76 \quad 77 \quad 78 \quad 7980 \quad 818283 \quad 8485$

Temperature $\left({ }^{\circ} \mathrm{F}\right)$

Figure 6-32 Histogram of winter average temperature in the Visitor Center

The temperatures below $65^{\circ} \mathrm{F}\left(18.3^{\circ} \mathrm{C}\right)$ typically occurred before noon; however there were a few days in 2001 when the temperatures were below $65^{\circ} \mathrm{F}\left(18.3^{\circ} \mathrm{C}\right)$ all day. It is unknown why the temperatures were low, but it is assumed that the occupants could have increased the temperature if they were uncomfortable.

Appendix E also contains histograms for the other zones during the winter along with a psychrometric plot.

The average interior temperature of the Visitor Center during the summer of 2002 was slightly warmer than the summer of 2001 (see Figure 6-33). The average temperatures were collected in 15-minute intervals while the building was occupied. Figure 6-33 shows the number of hours at specific average temperatures for the Visitor Center. During 2001, the temperature was greater than $78^{\circ} \mathrm{F}\left(25.6^{\circ} \mathrm{C}\right)$, only $2.6 \%$ of the hours. This percentage increased slightly to $3.7 \%$ during 2002 . It is believed that during 2002, the average temperature was slightly warmer mainly because of the warmer outdoor temperatures and partially because of the increased ventilation to the back offices. 


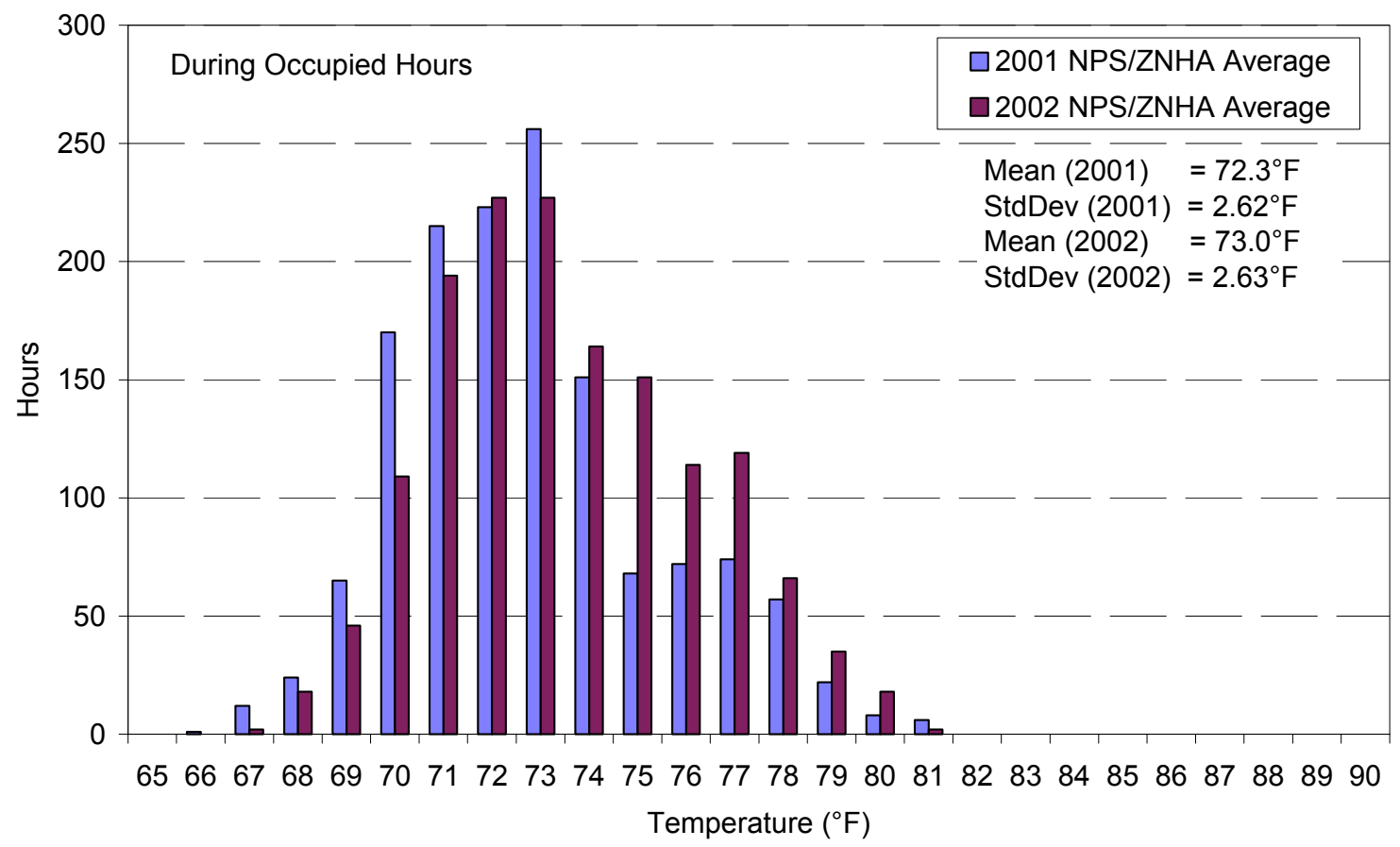

Figure 6-33 Histogram of hours at average temperature in the Visitor Center during summer

There were several problems cooling two of the zones in the Visitor Center. These zones (Zone 2 and Zone 7) are offices located next to the Trombe wall. Both zones experienced the same overheating problems in the summer. This is partially due to the Trombe wall providing heat to the space. Although the Trombe walls are shaded during the summer, some diffuse solar gains transmit through the Trombe wall and add heat to the space. Overheating this area was compounded by the lack of ventilation of the enclosed offices. In addition, occupants typically do not use the operable windows even when outdoor conditions are favorable.

During 2001, the temperatures in Zone 2 were unacceptable and action was needed to correct the situation. Figure 6-34 shows temperatures for Zone 2. During the winter of 2001-2002, small circulation fans were placed in the adjacent space and a door louver was installed to allow air to freely enter the space. This seemed to work effectively, as the average temperature in Zone 2 was decreased by $1.5^{\circ} \mathrm{F}$ $\left(0.8^{\circ} \mathrm{C}\right)$ along with a smaller standard deviation compared to the summer of 2001 to 2002. 


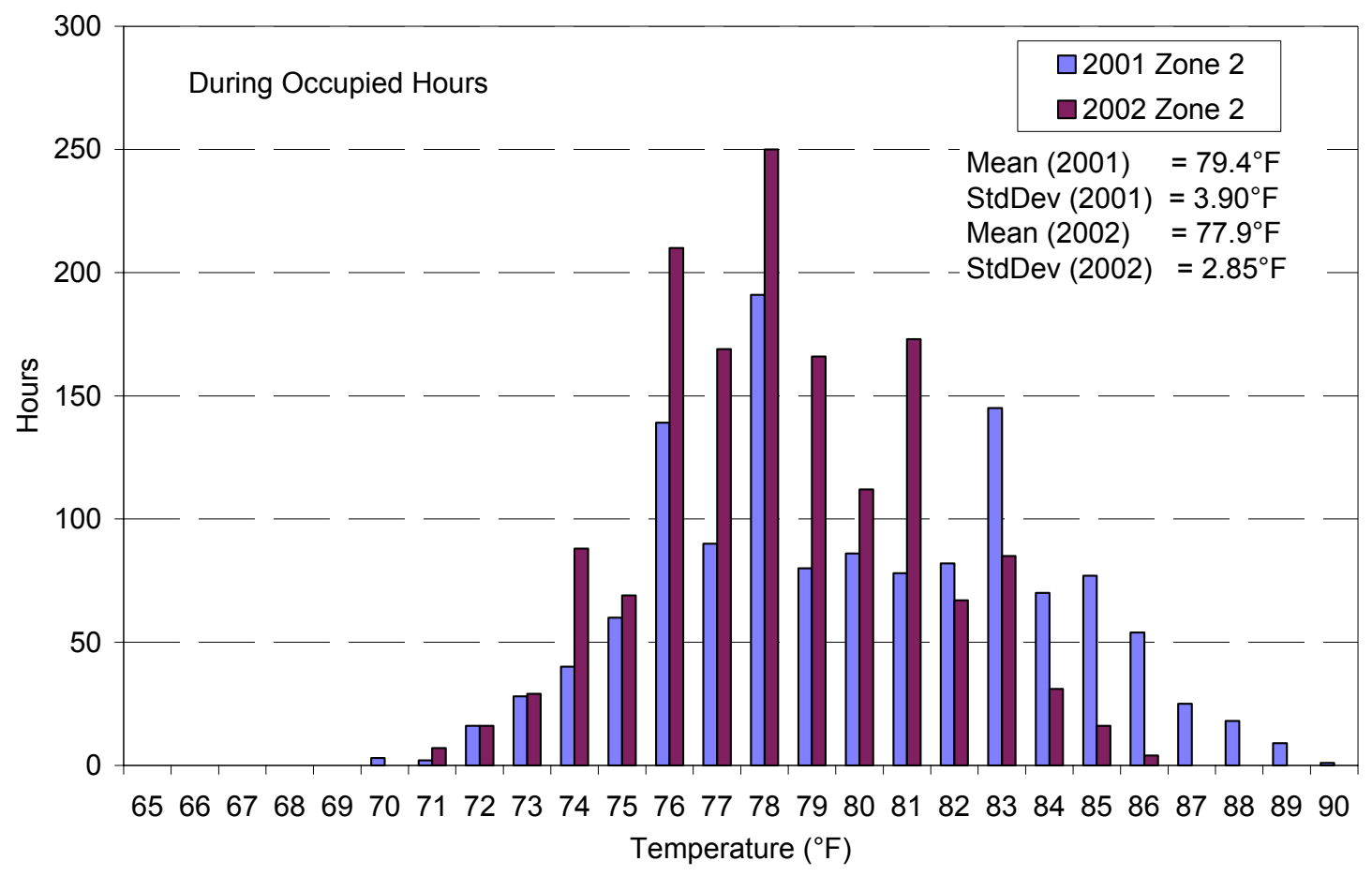

Figure 6-34 Visitor Center Zone 2 comfort histogram during summer

Zone 7 had a similar situation. Zone 7 is the bookstore office also located next to the Trombe wall. A small, unconditioned stock room is next to the office. This storeroom often overheats due to dark brown double doors that collect heat during the morning. The internal temperature of the door radiates to the occupants working in the storeroom, as shown in Figure 6-35 and Figure 6-36. The metal doors could not simply be painted white because the exterior coloring of the building had to follow NPS standards, which is dark brown. To help cool these two zones, several small fans were installed along the floor vents to help with ventilation. These were installed at the end of 2001. Operating these fans provided additional cooling to the storeroom and office. However, it has not completely alleviated the problem. 


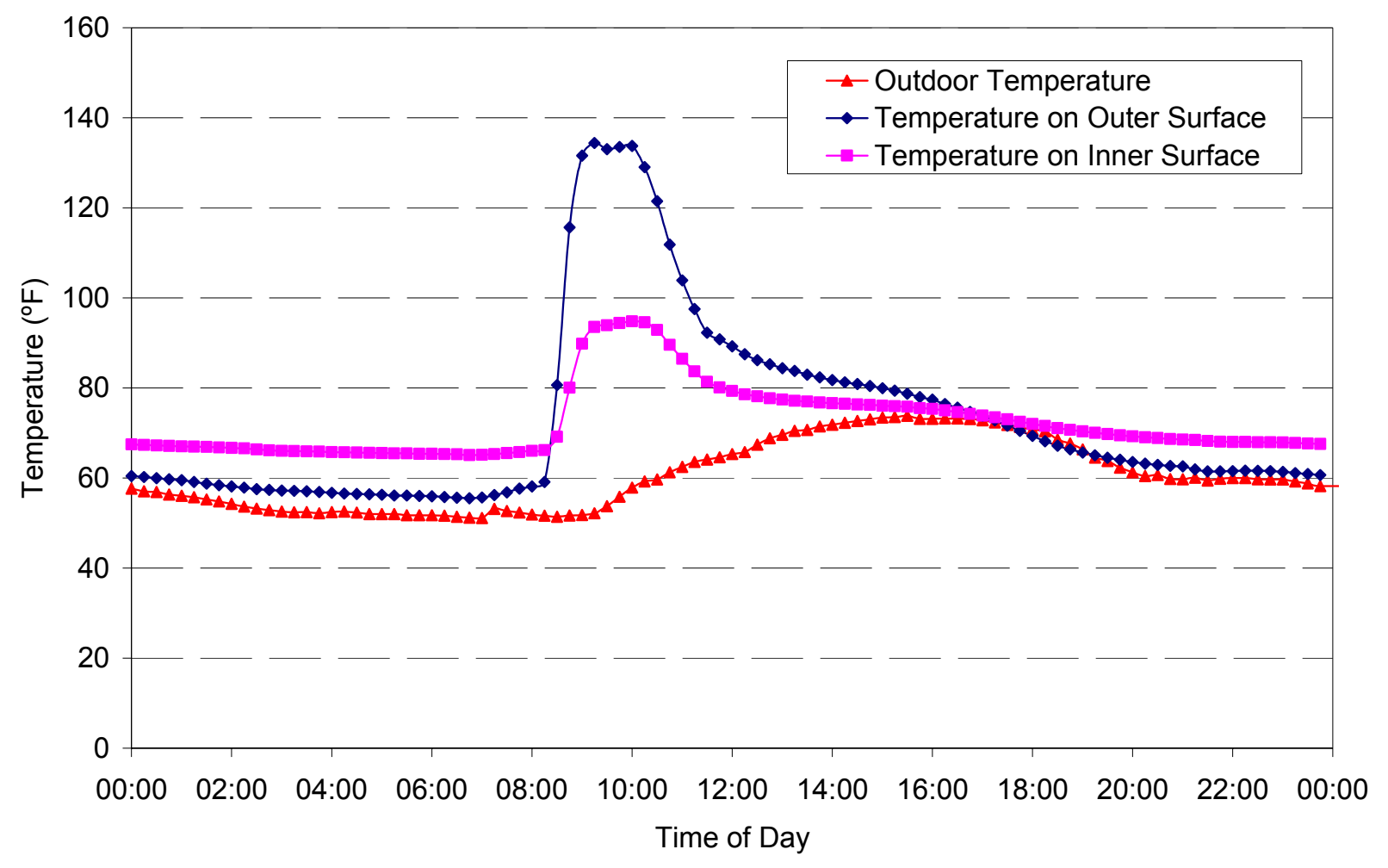

Figure 6-35 Zone 7 exterior door temperatures averaged over October 8, through October 19, 2001

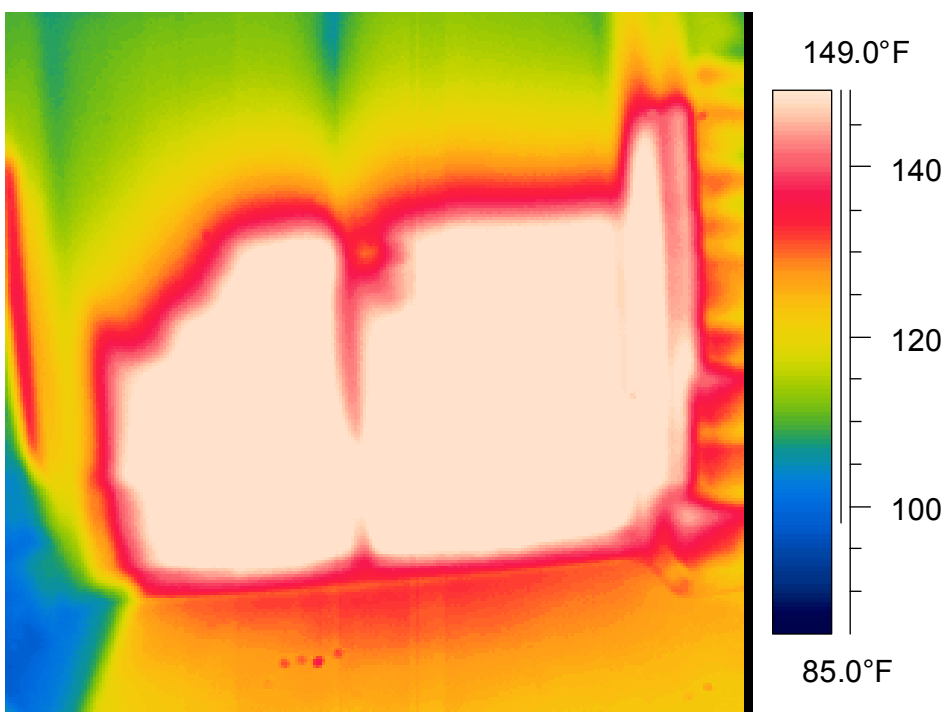

Figure 6-36 Infrared picture of the interior door in Zone 7, August 18, 2001 12:35 p.m. 


\subsection{Comfort Station Energy Evaluation}

The Comfort Station at ZNP is responsible for $15 \%$ of the total energy used at the Visitor Center Complex. The building uses $17.6 \mathrm{kBtu} / \mathrm{ft}^{2} \cdot \mathrm{yr}\left(200 \mathrm{MJ} / \mathrm{m}^{2} \cdot \mathrm{yr}\right)$ of site energy, with heavy traffic during summer months. The building used 14,230 kWh. The energy use for the Comfort Station divided into each month is shown in Figure 6-37.

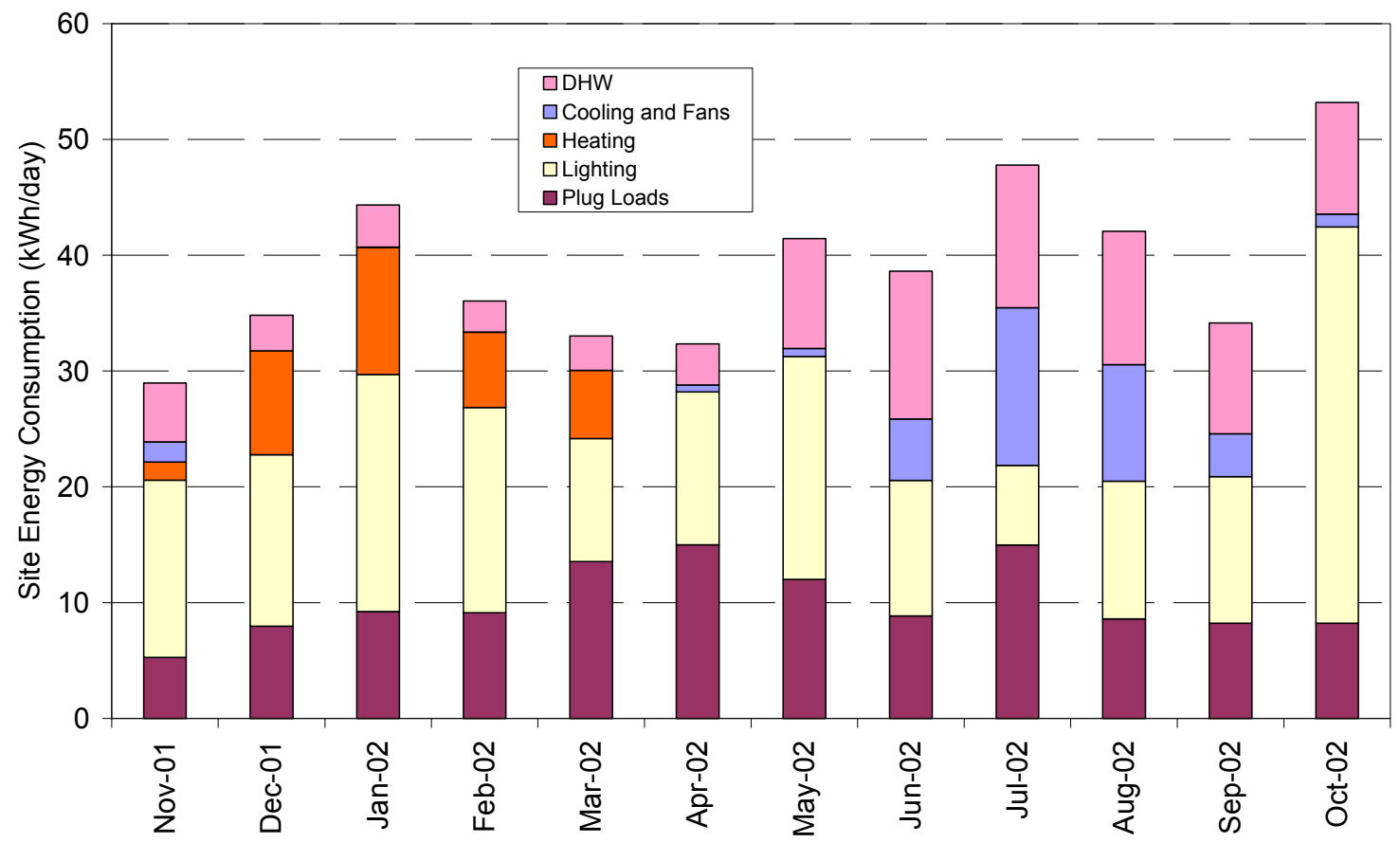

Figure 6-37 Comfort Station end use monthly consumption per day, November 2001 through October 2002

The majority of the energy used in the Comfort Station was for lighting and plug loads. The Comfort Station lighting loads contain continuously charging back-up batteries that draw about $300 \mathrm{~W}$ for emergency lighting.

The heating and cooling systems in the Comfort Station are similar to the systems in the Visitor Center. The Comfort Station uses a single cooltower for cooling. Heat from the radiant panels augments the Trombe wall heat to maintain set point temperatures. The designed comfort region for the Comfort Station was to maintain the facility between $55^{\circ} \mathrm{F}$ and $80^{\circ} \mathrm{F}\left(13-27^{\circ} \mathrm{C}\right)$ year round.

The hot water in the Comfort Station is primarily used to clean the restrooms. As a result, hot water is provided to all sinks, but it is not an issue if there is not enough capacity. The peak visitor season is in the summer. During the winter, half of the restroom area is closed to save energy and cleaning costs. See Figure 4-4 for closed sections.

Most of the heat for the Comfort Station is provided by the Trombe wall, except for the family restroom, because it does not have a southern exposed wall. The temperature histogram for the Comfort Station is seen in Figure 6-38. The graphs shows that the Comfort Station is maintained within the set point limits during the entire winter. The building overheated a few hours during the winter. 


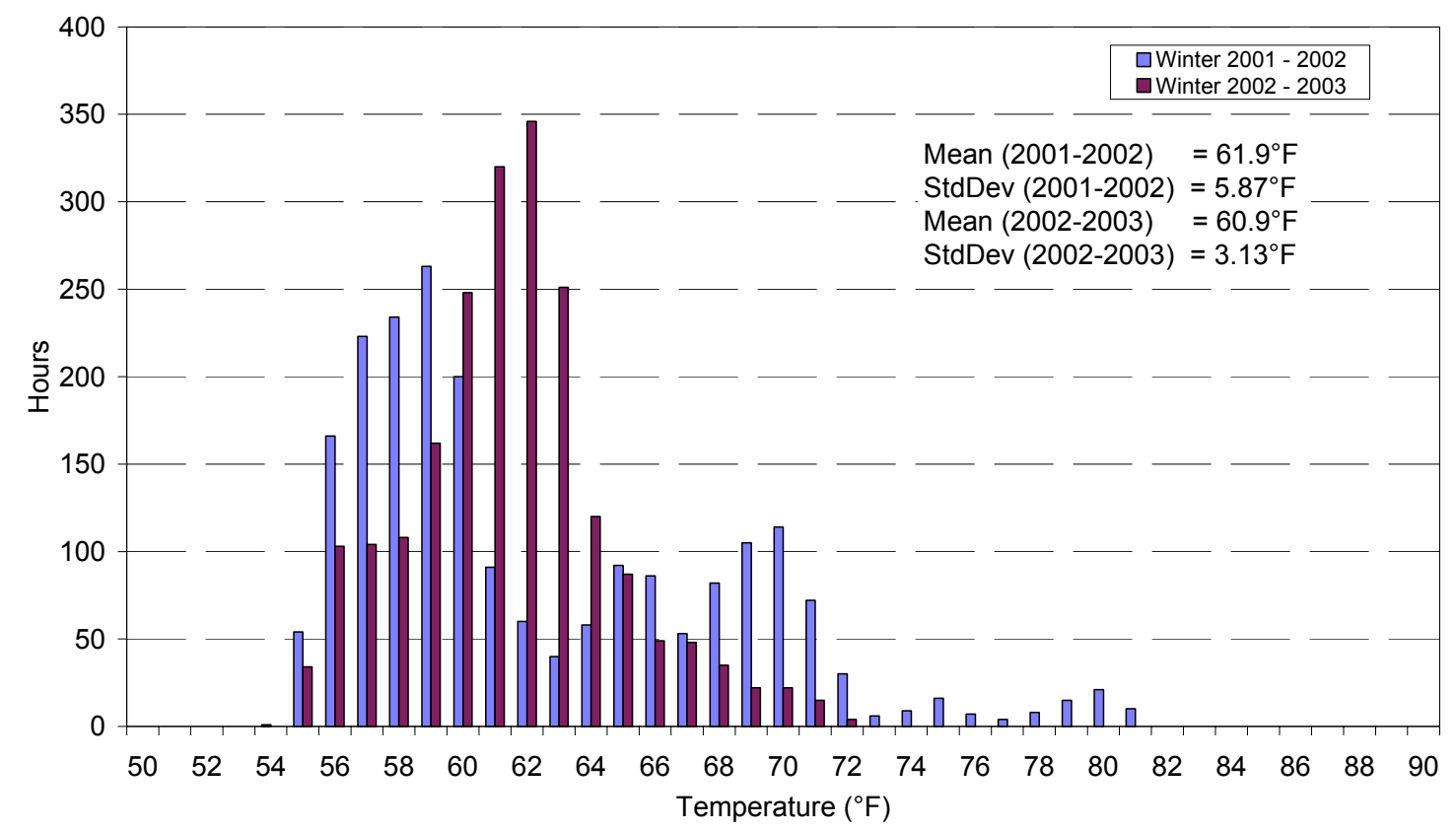

Figure 6-38 Histogram of hours at average temperature in the Comfort Station during winter

During the summer, the cooltower provides a reasonable temperature in the Comfort Station (see Figure 6-39). The temperatures in 2002 were much cooler than 2001. There was no design limit on the summer temperature. Eighteen percent of the hours in 2001 were above $80^{\circ} \mathrm{F}\left(27^{\circ} \mathrm{C}\right)$, while in 2002 , there were no above hours above $80^{\circ} \mathrm{F}\left(27^{\circ} \mathrm{C}\right)$.

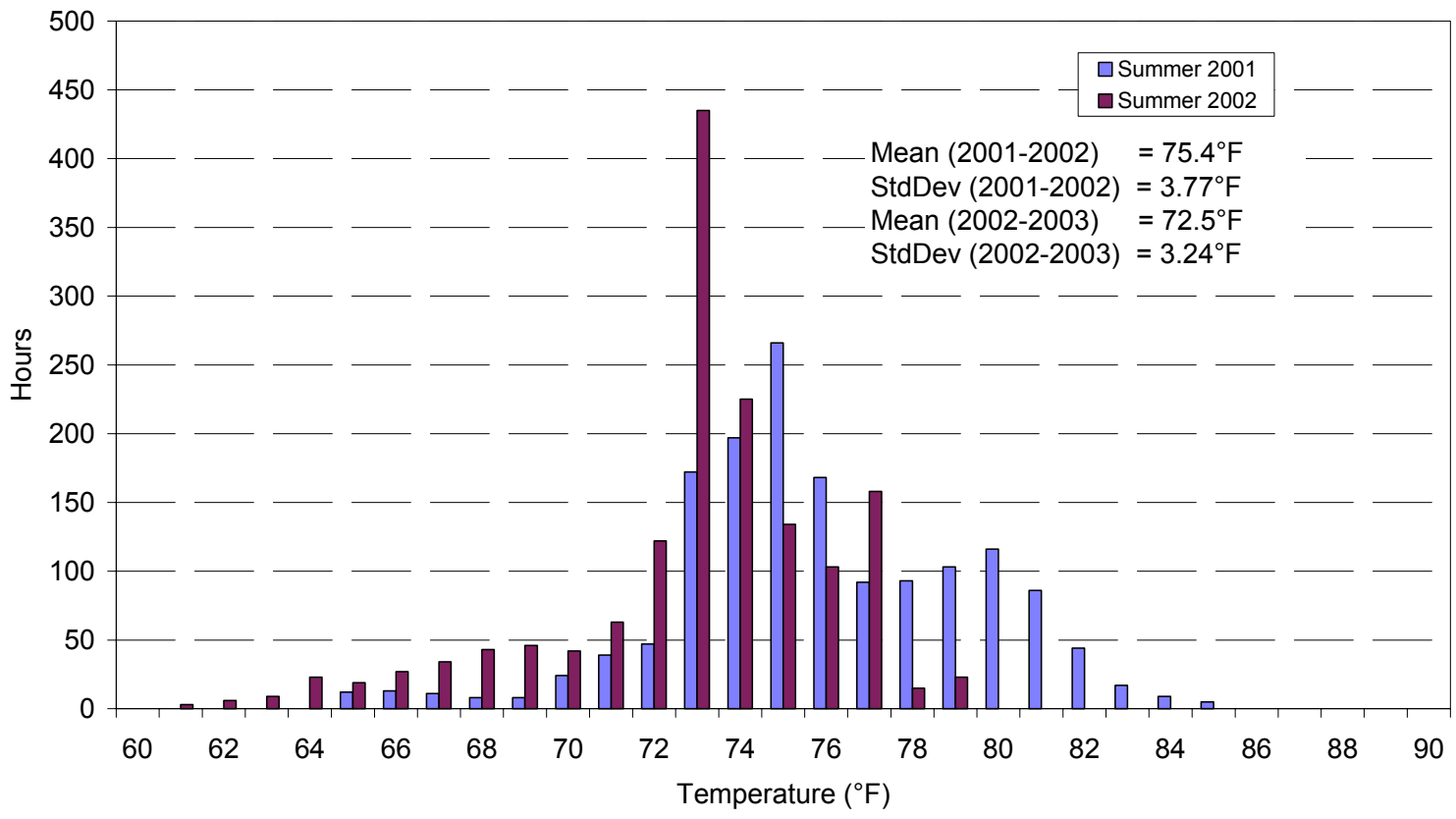

Figure 6-39 Histogram of hours at average temperatures in the Comfort Station during summer 


\section{Recommendations}

We derived the recommendations listed below from lessons learned during the project. They are intended to assist designers for future projects.

\subsection{Low-Energy Design Process}

This section discusses recommendations developed from evaluating the process used to deliver lowenergy commercial buildings.

\section{Recommendation \# 1: Set energy performance goals and remain committed to achieving them throughout the design process.}

Creating buildings with low-energy architecture requires the setting of clear, measurable energy performance goals and tracking progress toward that goal. Goals provide an energy saving target to achieve and a value to compare energy performance. For this project, an energy-cost saving goal of $70 \%$ (compared to minimum code) was adopted early in the design process (computer simulations showed that an energy saving goal of $80 \%$ was achievable). However, actual measured data indicated that the building energy cost saving was $67 \%$ because some construction and design changes were made before NREL could perform energy simulations to determine the energy impact of the changes. Nonetheless, by setting a high energy saving goal, remarkable savings were still achieved.

\section{Recommendation \# 1A: Use the architectural design and envelope of the building to save energy and enhance comfort.}

Form, shading, daylighting, choice of materials, sizing, orientation, and specification of glass all have a major impact on building energy, lighting, and comfort performance. Use the mechanical system to make up for what cannot be accomplished by architecture and envelope alone, not to correct for an architectural design that is climatically ill conceived.

\section{Recommendation \# 2: Apply a process that fosters a team approach to integrated design.}

It is important to involve the entire design team throughout the design process to reveal potential energy saving opportunities and to get a whole-team decision. By involving the whole design team from the predesign stage, team members that ordinarily are not involved until later can identify ways to improve the design before the building is constructed. Follow-up evaluations showed that participants in the Visitor Center Complex project agreed that the project benefited from the process adopted. Specifically, integrating the energy analyst directly into the process to guide architectural decisions created a building that worked well with the energy decisions.

\section{Recommendation \# 3: Update energy models as design development progresses.}

There were important changes to the design and siting of the Visitor Center that occurred late in the design development stage. Changes to the orientation and location of offices reduced the energy performance of the building. For example, offices were located adjacent to the Trombe wall and far from the cooltowers, which led to comfort problems. Had each design change been reanalyzed with detailed simulations and updated zoning, the comfort problems may have been predicted and corrected (e.g., by adding back into design the cooltowers that had been removed or moving the offices). It is critical to maintain the simulations from predesign through occupancy.

\section{Recommendation \# 3A: Watch out for "Transparency Creep"}

Glass has a very strong impact on energy, comfort, and lighting performance. These impacts can be positive or negative depending on many factors. Simulations allow us to optimize glass optical and 
thermal properties, sizing, orientation, placement, and shading. Additional glass is often added because of trying to achieve transparency of the building. The additional glass really does not provide transparency of the building because of the strong exterior contrast from the sun. The result is that the building is not transparent even with lots of glass. This building is overglazed on the north façade.

\section{Recommendation \# 4: Review architectural program with concern for energy performance.}

Altering the architectural program to move interpretive displays to an outside patio reduced the size of the building, resulting in enormous savings in first cost and overall energy use. Besides space area needs, establishing individual comfort ranges for the buildings and allowing for interruptible hot water further improved the building's energy efficiency. It is beneficial to identify areas where generally accepted design criteria may be replaced with creative energy saving solutions that meet or exceed the functional requirements of the building.

\subsection{Visitor Center Complex Systems}

Several lessons were learned after construction and during initial occupancy about the performance of the following systems: demand responsive controls, cooltowers, Trombe walls, electric heating, lighting and daylighting systems, and the solar-electric system.

\subsubsection{Demand Responsive Controls}

This section presents recommendations developed from experiences implementing control strategies in the BAS that attempt to reduce the peak draw of electricity over a 15-minute period in any given billing cycle.

\section{Recommendation \# 5: Develop stable demand controllers and strategies.}

Demand controlling for the Visitor Center Complex worked well in aggregate, but we found that isolated failure events lasting more than 15 minutes could instigate an excessive demand charge for that month. Software routines and hardware need to be reliable and default to appropriate settings after a system failure so that system resets are rare and not problematic. By the end of the monitoring period, the software was robust and provided good demand management. As with any system, improvements can still be made.

\section{Recommendation \# 6: Include forecasted weather data in demand responsive controls.}

Experience with the Visitor Center Complex suggests that better performance could be obtained if forecasted data were used in addition to historic data in the demand control algorithms. Weather forecasts are readily available and can be used to make control decisions.

\section{Recommendation \# 7: Investigate using short-term battery storage to offset peak demands.}

Although the existing battery storage at the Visitor Center Complex is probably not sufficient, the presence of all the needed components suggests that demand could be offset by using UPS systems. To do this, the inverter must be able to communicate with the BAS.

\section{Recommendation \# 8: Reevaluate thermostat setup/setback strategies.}

High-thermal-mass buildings such as those in the Visitor Center Complex may show increased demand charges because of nighttime setback of the thermostats. Analysis should be performed to better 
understand the interactions between energy use and demand charges in order to determine optimal setback strategies.

Recommendation \# 9: If PV is to be included in a project, use building energy simulation programs that model PV with demand interactions.

Experience with Visitor Center Complex called attention to the need to model demand controlling and interactions with PV generation. The lack of modeling prevents researchers from determining the full effectiveness of the current demand control strategies. Using a building simulation program that includes PV will allow for analysis on demand responsive controls and integrated cost analysis. Simulation programs also need to have the ability to study demand-limiting controls.

Recommendation \# 10: Use EnergyStar ${ }^{\circledR}$ enabled computers and flat screen monitors.

Parasitic loads are a problem in commercial buildings. Part of this load is idle computers. Energy savings can be realized by making the machines EnergyStar enabled to shut them down during periods of inactivity. Flat screen monitors should also be used for added energy savings.

\subsubsection{Trombe Walls}

This section provides recommendations related to the Trombe walls located along the south walls of the Visitor Center and Comfort Station.

Recommendation \# 11: Consider Trombe walls for passive heating of commercial buildings.

Trombe walls were effective in providing a significant portion of the heating. It is clear that this building is heating dominated. Passive solar heating of commercial buildings has not been used very often because conventional wisdom indicates that such buildings need little heating. However, low-energy commercial buildings tend to require more heating because of reduced internal gains.

Recommendation \# 12: Provide effective shading and/or active control for Trombe walls during the cooling season.

The Trombe wall with its overhang was effective in maximizing the heat gains in the winter. However, although reduced, the diffuse solar component still partially heats the wall in the summer when the heat is not desired (see Section 6.1.2). This problem was compounded by limited cooling capacities in the offices that were against the Trombe wall. Movable exterior shades are one possible means of mitigating unwanted heat during the cooling season. The walls should have been resized to better match the heating loads for these spaces.

\subsubsection{Electric Heating}

This section discusses recommendations related to the use of electric heat.

\section{Recommendation \# 13: Consider electric radiant heating.}

An electric radiant heating system was used in the current project because it offered several advantages. The Visitor Center Complex's buildings do not require a lot of heat and a ducted air system was not used for cooling. Therefore, it was considered too costly and complex to add a mechanical air system and the associated ductwork for a small amount of heating. We arranged electric radiant heaters to direct heat at the locations where staff would spend the most time. Results show that occupants allowed lower thermostat temperature set points; these results are most likely because the radiant heating can provide comfort at lower dry-bulb temperatures. Electric radiant heaters also allow for a more cost-effective and 
precise temperature control because many thermal zones can be created. Although the electric heaters contribute to demand charges, they are simple to control. The cost of propane and transportation were key considerations in the creation of an all-electric building. The key is heating the building without incurring additional demand charges. Note that this decision is highly dependent on the metrics used to measure success. The solution was successful from a cost basis, but it is not as favorable on a source energy basis.

\section{Recommendation \# 14: Consider air-source heat pump heating.}

Although the electric radiant panels have been successful, it may have been appropriate to install a small air-to-air heat pump to provide some heating with electricity. A unitary system located on the north side of the building (away from the Trombe walls) would probably have been a good choice. An air-source heat pump can provide COPs between about 1.0 and 3.0, depending on outside air temperatures, whereas electric resistance always has a COP of 1.0.

\subsubsection{Cooltowers}

This section lists recommendations related to the cooltowers. These architectural features combine direct evaporative cooling with natural ventilation. The cooltowers work well to provide cooling to the main area of the Visitor Center. Visitors find the towers fascinating and give them the type of attention often given to large fireplaces in public areas. The interaction of the visitors with the cooling system provides an amenity that normally would not be achieved with a traditional cooling system. This was not expected - that visitors would place value on the cooling system as an amenity for the building.

\section{Recommendation \# 15: Provide multiple opportunities for passive airflow.}

As a special class of passive natural ventilation, the use of cooltowers requires careful design of interior partitions and fenestration to promote good circulation of cooled air. The enclosed offices in the building tend to overheat due to insufficient airflow and continual heat gains from the Trombe wall. Exhaust fans originally installed in the office area were not sufficient to move air through these spaces to counteract the heat gains from Trombe walls. As with many passive systems, moving air mechanically should be avoided. The Trombe wall is shaded in the summer, but the diffuse component of the solar radiation still heats the wall. In the initial building design, the Trombe walls were to be adjacent to open spaces, not the enclosed offices. Late in the design process, the interior layout of the building was changed to place enclosed offices on the south side of the building adjacent to the Trombe walls. Even in the winter, this Trombe wall provides more heat than needed to the office spaces. As a result, circulation fans were installed between the public and private spaces to help induce additional air flow. These fans improved the comfort of the office spaces; however, they also increased the fan energy use and noise, which is to be avoided in passive cooling and heating.

\section{Recommendation \# 16: Use dampers on automatic controls rather than operable fenestration for natural ventilation.}

Operable windows are an important part of the natural ventilation system in the Visitor Center. Windows located near the ground are operated manually while clerestory windows are on automated actuators. Experience showed that occupants did a poor job of operating the manual windows. In addition, the motorized window actuators were prone to failure and were difficult to interface with th e BAS. Furthermore, the windows did not open much and the window screens reduced the effective opening. One suggestion is to separate the ventilation from the fenestration and use relief dampers for the passive ventilation. This would also increase the fenestration area and help with the daylighting. The control actuators would be typical HVAC controllers, reducing maintenance and integration issues. 


\section{Recommendation \# 17: Provide solar shading of cooltower media.}

No shading was designed into the cooltowers to shade the media from direct exposure to sunlight. Although the consequences were not quantified, researchers suspect that solar shading would reduce water consumption. Reducing UV degradation of the exterior media surface is another advantage of shading as well as the visible dissolved solids that accumulate on the exterior of the surface.

\section{Recommendation \# 18: Size sump pits to hold all the water in the system.}

To avoid wasting water, systems should be sized to avoid overflows. The Visitor Center Complex cooltowers include a sump pit that was not sized large enough to hold all the in-transit water. The installed sump pit has a 20-gallon (76 liter) capacity. The trays and media, when wetted, hold about 20 30 gallons (76-114 liters) of water, which makes it possible for about 10-15 gallons (38-57 liters) of water to overflow the drain when the pump cycles off. This water is made up with fresh water when the pumps turn back on.

\section{Recommendation \# 19: Consider using inlet scoops and/or louvers at the top of cooltowers.}

Although it cannot be determined from the current data, there are several possible mechanisms for moisture to be entrained into the air passing by the tower and transported away from the tower without providing cooling to the building. Better control of how winds interact with the openings of the cooltower may alleviate water waste and improve air circulation. Installing inlet louvers on the outside of the evaporative media may channel air straight into the tower and prevent air passing adjacent to the towers (but not entering tower) from coming into direct contact with the wetted exterior surface. Such louvers may also provide solar shading. The change could also enhance passive natural ventilation. Modeling should be done to determine if there are advantages to only using windward pads to coincide with the prevailing winds in the canyon.

\section{Recommendation \# 20: Ensure that the plumbing system for the cooltowers is robust.}

Ensure that the plumbing system for the cooltowers is robust. The initial plan was changed after the first few weeks of operation to allow for additional drain flows and better fresh-water inlet control. Drains were poorly detailed and undersized resulting in overflows.

\section{Recommendation \# 21: Detail water circulation system to handle air-borne debris.}

In the Visitor Center Complex cooltowers, the trays that collect water extend about 1.5 in. $(3.8 \mathrm{~cm})$ beyond the cooling media. Leaves are caught in the trays and then migrate past the cooling media at the corners and enter the water circulation system. The bleed valve has clogged on occasion because of leaves getting into the system. Although improved details may reduce the debris, the water circulation system needs to be robust enough to handle it.

\section{Recommendation \# 22: Consider wind loads on cooltower components.}

The open, upper area of the towers is continuously exposed to wind. The water distribution components that wet the cooling media were not designed appropriately, causing the high winds to occasionally shift the water spraying components so that water misses the media. The distribution system for the water needs to be redesigned to be robust.

\section{Recommendation \# 23: Detail inside of cooltower as if it were exterior facade.}

The inside walls of the cooltowers should be considered exterior to prevent water damage because they are constantly exposed to moist air. The interiors of the cooltowers were lined with drywall. As a result, they have had moderate damage (i.e, pealing paint) due to the high humidity, occasional water sprays 
(high wind conditions), and improperly flashed or sealed tower tops. Rainwater can work its way onto the sills, seep between the bottom of the cooling media frames, and run down the inside of the wall. A suggestion is to build the towers from masonry block, rather than tubular steel.

\subsubsection{Lighting and Daylighting Systems}

This section discusses recommendations related to the lighting and daylighting systems in the Visitor Center Complex. Daylighting was significantly less than originally predicted.

\section{Recommendation \# 24: Provide high reflectivity finishes to spaces that are daylit or have indirect light fixtures.}

Instead of NREL's recommended white ceiling, a light-color pine, tongue-and-groove ceiling was installed in the Visitor Center. Designers intentionally chose the white ceiling to incorporate diffuse light in the space to reflect the lighting characteristics within the narrow slot canyon of ZNP, keep direct solar heat gain to a minimum, and make the building interior psychologically cooler. The darker ceiling that was installed appears to have decreased the daylighting effectiveness in the space. This decreased effectiveness is compounded by the use of $88 \%$ uplighting fixtures with the low reflectance ceiling.

Recommendation \# 25: Account for window screens, attachments, and actual view area in daylighting analyses.

Experience with the Visitor Center suggests significant reductions in daylight entering fenestration because of screens, reduced window view area due to mullion thickness, and shading deployed to reduce glare problems. It is essential during the design phase to size the fenestration based on glass area and not the opening area, which would include the impact of the frame and screens.

\section{Recommendation \# 26: Account for structural elements in daylighting analyses.}

Predictions related to daylighting during design development neglected the structural beams. The interior of the Visitor Center has a large number of dark-colored wood beams and researchers have determined that these contributed to the poorer-than-expected daylighting performance. Indirect lighting fixtures were installed level to the horizontal beams in the space, some distance below the ceiling. This also made the uplighting fixtures not as efficient as intended. This is an extension of the Recommendation \#3 for using simulations throughout the design process to assess architectural finishes.

Recommendation \# 27: Provide lighting controls that dim in response to natural daylight.

The lighting controls in the Visitor Center Complex are stepped controls. When the electric lights switch on or off, the occupants tend to be distracted. Dimming controls were added to minimize distractions from the cycling of lights. The dimming system can still be turned off.

\section{Recommendation \# 28: Provide task lighting to augment daylighting.}

The absence of task lighting further decreased the effectiveness of the daylighting system because occupants required more use of overhead lighting to maintain sufficient lighting levels in work areas. Task lighting was installed in these areas after the building was occupied. Use of task lighting permitted building operators to decrease the ambient lighting threshold that controls the electric lighting. A similar problem existed in the Comfort Station where additional lighting was needed over the sinks. After occupancy, more lighting was provided over the sinks and the general lighting level could then be decreased. During the design phase, high priority areas should be identified for possible task lighting or increased daylighting. Tubular daylighting devices could have provided necessary lighting over the sink area in the Comfort Station. 


\section{Recommendation \# 29: Consider separate emergency lighting.}

Fixtures with integral backup ballasts were selected for the Comfort Station. These back-up batteries draw $300 \mathrm{~W}$ even when the light fixtures are off. The Visitor Center used wall packs to achieve the same effect at a fraction of the power consumption. Lower power, self-contained wall pack light assemblies would have been a better choice and would have reduced the parasitic load.

\section{Recommendation \# 30: Consider special controls for cleaning.}

Cleaning commercial buildings requires ample light and special control modes that accommodate cleaning crews should be considered. A cleaning override switch for the Comfort Station was successful. This switch enables the lights through the BAS for cleaning. When the cleaning crews leaves, the switch can be turned off to return to daylighting control. If the switch is not shut off, the BAS will return to the daylighting control scheme after 90 minutes.

\section{Recommendation \# 31: Install easy to use switches for lighting controls.}

The main building lighting was controlled with an occupied/unoccupied button on the thermostat. It was difficult to train staff to use this control device for lighting. As a result, the system was programmed to turn on the lights at a set time each morning and to sequence down in the evening. User interfaces are critical for success of the BAS. It would have been better to provide an input resembling a traditional light switch. There has been some success in using the lighting control late in the project, allowing NPS staff to change the occupied time from 6:00 a.m. to 7:00 a.m. The impact of the user interface cannot be underestimated.

\section{Recommendation \# 32: Reduce the lighting in the Comfort Station.}

The Comfort Station was overlit on both the LPD and the lighting intensity. Some fixtures could be eliminated, saving maintenance and energy costs.

\section{Recommendation \# 33: Minimize the number of motion/occupancy sensors.}

The original plan had several motion sensors in the Comfort Station on the same lighting control, making it difficult to identify a single failed sensor. It is easiest to have a one-to-one correspondence between the sensors and the fixtures. The design was changed to just have one sensor in each half of the restroom with a 20-minute delay. This has worked well. In addition, at night, when occupancy is low, the sensor only turns lights on above the sink and in the hallway to minimize the glare and the contrast between inside and outside.

\subsubsection{PV and UPS System}

This section provides recommendations related to the PV and UPS systems.

\section{Recommendation \# 34: Consider specifications for how a PV-based UPS system transitions to and from utility power.}

The reliability of electrical utility power at ZNP is poor, especially during the summer thunderstorm season. Sometimes power failures are not abrupt but include frequent cycling. For example, in one case, the power turned on and off 40 times in less than 5 seconds before disconnecting. Because of this, the main UPS system has had difficulties determining when to disconnect from and reconnect to the utility power. The reliability of the PV system itself has been excellent, but its use as a UPS has not been satisfactory. As a result, some smaller, self-contained UPS systems were installed on critical devices. Future efforts to use PV systems for building-wide UPS should carefully investigate how the equipment responds to the types of power failures the building is likely to experience. 


\section{Recommendation \# 35: Plan for future addition of PV.}

Experience with the Visitor Center Complex project showed that designing a building to be ready for the future addition of a PV system could add value. Although funds for a PV system were not originally available, the Visitor Center was configured for such a system, making it simple to install once funds were available. Although some buildings may never have the need for PV, those that do may benefit from roof angles and orientation designed for future installation of a PV system, including pre-installing conduit, roof penetrations, and anchoring points.

\section{Recommendation \# 36: Install PV panels where they will not be shaded.}

PV panels should be located where they will not be shaded. The annual performance of the Visitor Center PV system is degraded by $7 \%$ because a tree partially shades the west set of modules late in the afternoon. Another option would be to remove the tree that is causing the shading. It is essential to understand the interactions between nature shading the PV panels and the environmental benefits of having additional PV production.

\section{Recommendation \# 37: Install maximum power-point tracking controllers for PV.}

A maximum power-point tracking voltage controller would increase performance of the Visitor Center PV system by $16 \%$ as compared to the fixed operating voltage control of 53.6 VDC.

\subsection{Commissioning}

\section{Recommendation \# 38: Plan for continuous commissioning.}

Experience with the Visitor Center Complex confirms that continuous commissioning efforts are required to achieve and maintain low-energy buildings. Despite the inevitable problems, the lack of mechanical systems made the Visitor Center Complex relatively simple to commission. A partial list of findings during normal commissioning includes: clerestory glare, lack of appropriate task lighting, bathroom exhaust fan was blocked, PV system had various problems, operable cooltower doors and clerestory windows were difficult to interface with the BAS. Continuous commissioning was found to further improve the energy performance. The evaluator's continuous postoccupancy monitoring, analysis, and improvements over many years have helped to realize a low-energy building.

\subsection{Postoccupancy Research Methods}

This section discusses recommendations for researchers engaged in similar postoccupancy studies.

\section{Recommendation \# 39: Use dedicated, self-contained data acquisition equipment for monitoring energy performance.}

This study used the BAS to collect data on the performance. This method was found to be problematic and should be avoided. With current BAS and energy management systems, there appears to be a low probability of obtaining contiguous, error-free, measured data sets over a long period. A better solution is to use dedicated, self-contained data acquisitions systems designed for unattended remote operation that do not use operating systems designed for personal computers.

\section{Recommendation \# 40: Provide researchers studying a particular building with direct access to the BAS.}

In the Visitor Center Complex project, researchers had access to and control of the BAS, which was helpful to understand and influence how the building was being controlled. Researchers were able to improve energy management strategies such as implementing and testing various demand responsive 
strategies. Access to the BAS allowed us to reduce the demand charges to the building and facilitated continuous commissioning activities. Another advantage of BAS access and control is having a full understanding of the various set points and control strategies to use as inputs into building energy simulation.

\section{Recommendation \# 41: Determine whole-building energy savings with as-built and base-case model comparisons.}

Ideally, the base-case site energy use, source energy use, and energy costs would be compared to an as-built model to calculate savings for a typical weather year. Energy savings uncertainties can be minimized when savings are determined from the comparison of one simulation to another simulation (e.g. base case to as-built). Because difficult-to-know inputs are held the same in both simulations, such comparisons remove much of the uncertainty inherent in an hourly building energy simulation. Variables that change throughout the year, such as inconsistent occupancy, set point changes, and equipment performance degradation, are difficult to account for in an annual building energy simulation. By comparing a base-case model to an as-built model with the same schedules, the uncertainty caused by these inconsistent variables is reduced. In the analysis of Zion, an as-built model of the Zion Visitor Center and Comfort Station was beyond the scope of this analysis due to limitations in the whole-building simulation tools. These limitations include nonexistent building integrated modeling techniques for the energy use and cooling capacity of cooltowers, difficulties modeling the as-built operation of subhourly demand limiting controls with integrated PV production, and uncertainties with Trombe wall thermal models. We attempted to account for the inherent uncertainty involved in comparing measured data to a simulation by calibrating the base-case model with measured weather data, measured equipment loads, and operation schedules. 


\section{Conclusions}

The Visitor Center Complex opened in May 2000 and includes an 8,800- $\mathrm{ft}^{2}\left(818-\mathrm{m}^{2}\right)$ Visitor Center (with interpretative displays, offices, and retail space for the ZNHA), a 2,756- $\mathrm{ft}^{2}\left(256-\mathrm{m}^{2}\right)$ Comfort Station (with restrooms), and a $170-\mathrm{ft}^{2}\left(15.8-\mathrm{m}^{2}\right)$ entrance Fee Station. The building was evaluated by comparing the measured energy use to the energy use of a simulated model. The major results of the performance are presented below and are divided into whole-building performance (both measured and simulated), PV performance, lessons learned, and future research.

\subsection{Measured Whole-building Performance}

From November 2001 through October 2002, the annual energy costs for the Visitor Center Complex were $\$ 5,094 / \mathrm{yr}$ or $\$ 0.43 / \mathrm{ft}^{2} \cdot \mathrm{yr}\left(\$ 4.63 / \mathrm{m}^{2}\right)$, net site energy use was $85,000 \mathrm{kWh} / \mathrm{yr}$ or $24.7 \mathrm{kBtu} / \mathrm{ft}^{2} \cdot \mathrm{yr}(281$ $\left.\mathrm{MJ} / \mathrm{m}^{2} \cdot \mathrm{yr}\right)$, and source energy intensity was $80 \mathrm{kBtu} / \mathrm{ft}^{2} \cdot \mathrm{yr}\left(909 \mathrm{MJ} / \mathrm{m}^{2} \cdot \mathrm{yr}\right)$. The average daily energy use is presented in Figure 8-1. Table 8-1 summaries the energy use during the evaluation.



Figure 8-1 End use daily average monthly consumption, November 2001 through May 2003 
Table 8-1 Measured Whole-Building Results

\begin{tabular}{|c|c|c|c|c|c|}
\hline $\begin{array}{c}\text { Measured Site } \\
\text { Use Intensity } \\
\mathrm{kBtu} / \mathrm{ft}^{2} \cdot \mathrm{yr} \\
\left(\mathrm{MJ} / \mathrm{m}^{2} \cdot \mathrm{yr}\right)\end{array}$ & $\begin{array}{c}\text { Measured PV } \\
\text { Production } \\
\text { Intensity } \\
\mathrm{kBtu} / \mathrm{ft}^{2} \cdot \mathrm{yr} \\
\left(\mathrm{MJ} / \mathrm{m}^{2} \cdot \mathrm{yr}\right)\end{array}$ & $\begin{array}{c}\text { Percent of } \\
\text { Building } \\
\text { Load Met By } \\
\mathrm{PV}\end{array}$ & $\begin{array}{c}\text { Measured Net } \\
\text { Site Use } \\
\text { Intensity } \\
\mathrm{kBtu} / \mathrm{ft}^{2} \cdot \mathrm{yr} \\
\left(\mathrm{MJ} / \mathrm{m}^{2} \cdot \mathrm{yr}\right)\end{array}$ & $\begin{array}{c}\text { Measured } \\
\text { Source Use } \\
\text { Intensity } \\
\mathrm{kBtu} / \mathrm{ft}^{2} \cdot \mathrm{yr} \\
\left(\mathrm{MJ} / \mathrm{m}^{2} \cdot \mathrm{yr}\right)\end{array}$ & $\begin{array}{c}\text { Energy Cost } \\
\text { Intensity } \\
\$ / \mathrm{ft}^{2} \cdot \mathrm{yr} \\
\left(\$ / \mathrm{m}^{2} \cdot \mathrm{yr}\right)\end{array}$ \\
\hline $\begin{array}{c}27.0 \\
(307)\end{array}$ & $\begin{array}{c}2.3 \\
(26)\end{array}$ & $8.5 \%$ & $\begin{array}{c}24.7 \\
(281)\end{array}$ & $\begin{array}{c}80 \\
(910)\end{array}$ & $\begin{array}{c}\$ 0.43 \\
(\$ 4.63)\end{array}$ \\
\hline
\end{tabular}

\subsection{Simulated Whole-Building Performance}

A base-case energy model, which used calibrated internal gains and weather data measured at the site for the same period, predicted energy costs of $\$ 15,250 / \mathrm{yr}$ or $\$ 1.30 / \mathrm{ft}^{2} \cdot \mathrm{yr}\left(\$ 13.99 / \mathrm{m}^{2} \cdot \mathrm{yr}\right)$. The base-case model predicted site energy use at $241,800 \mathrm{kWh} / \mathrm{yr}$ or $70.3 \mathrm{kBtu} / \mathrm{ft}^{2} \cdot \mathrm{yr}\left(798 \mathrm{MJ} / \mathrm{m}^{2} \cdot \mathrm{yr}\right)$ and source energy intensity at $227 \mathrm{kBtu} / \mathrm{ft}^{2} \cdot \mathrm{yr}\left(2,580 \mathrm{MJ} / \mathrm{m}^{2} \cdot \mathrm{yr}\right)$. This represents savings (including receptacle loads) of $67 \%$ for energy cost, $62 \%$ for site energy (not including on site generation), and $65 \%$ for source energy (see Figure 8-2 and Table 8-2). The measured energy cost savings shows that the original energy design goals are close to being met.

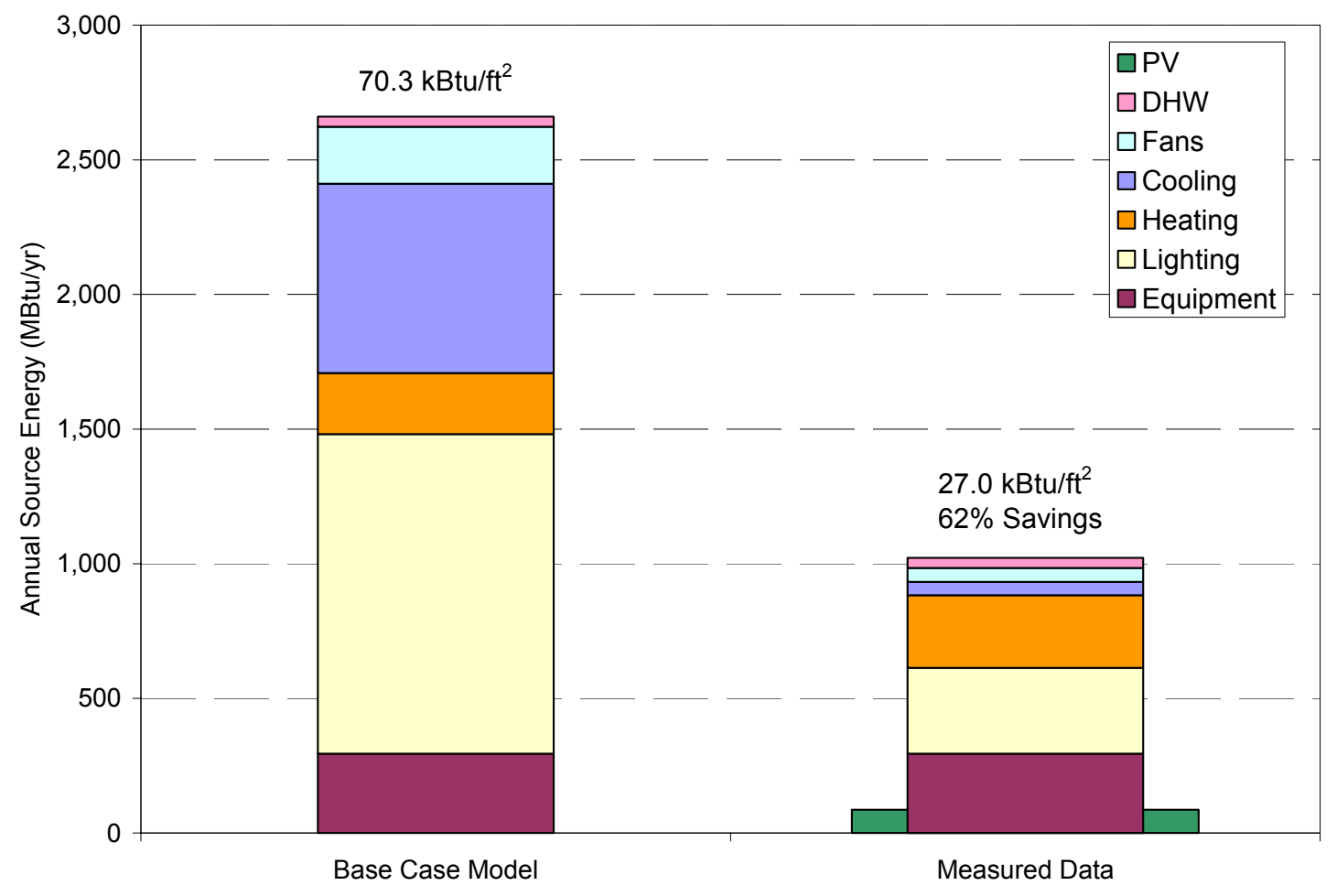

Figure 8-2 Annual performance comparison 
Table 8-2 Cost, Site, and Source Energy Savings, Nov. 2001 to Oct. 2002

\begin{tabular}{|c|c|c|c|c|c|c|}
\hline & \multicolumn{2}{|c|}{ Cost } & \multicolumn{2}{|c|}{ Site Energy } & \multicolumn{2}{|c|}{ Source Energy } \\
\hline & $\begin{array}{c}\$ / \mathrm{ft}^{2} \cdot \mathrm{yr} \\
\left(\$ / m^{2} \cdot y r\right)\end{array}$ & $\begin{array}{l}\text { Percent } \\
\text { Savings }\end{array}$ & $\begin{array}{l}\mathrm{kBtu} / \mathrm{ft}^{2} \cdot \mathrm{yr} \\
\left(\mathrm{MJ} / \mathrm{m}^{2} \cdot \mathrm{yr}\right)\end{array}$ & $\begin{array}{l}\text { Percent } \\
\text { Savings }\end{array}$ & $\begin{array}{l}\mathrm{kBtu} / \mathrm{ft}^{2} \cdot \mathrm{yr} \\
\left(\mathrm{MJ} / \mathrm{m}^{2} \cdot \mathrm{yr}\right)\end{array}$ & $\begin{array}{l}\text { Percent } \\
\text { Savings }\end{array}$ \\
\hline Base-case & $\begin{array}{c}\$ 1.30 \\
(\$ 13.99)\end{array}$ & $670 /$ & $\begin{array}{l}70.3 \\
(798)\end{array}$ & 600 & $\begin{array}{c}227 \\
(2580)\end{array}$ & 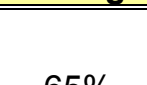 \\
\hline As-built & $\begin{array}{c}\$ 0.43 \\
(\$ 4.63)\end{array}$ & $6 / \%$ & $\begin{array}{l}27.0 \\
(307)\end{array}$ & $0<\%$ & $\begin{array}{c}80 \\
(910)\end{array}$ & $65 \%$ \\
\hline
\end{tabular}

\subsection{PV System}

The PV system offsets approximately $15 \%$ of the loads during the spring and summer months. It offsets less than $5 \%$ of the load during the winter because of the higher electrical loads from heating and reduced PV production. During the monitored year, the PV system produced a net 7,861 kWh (building normalized to $\left.2.3 \mathrm{kBtu} / \mathrm{ft}^{2} \cdot \mathrm{yr}\left[26.1 \mathrm{MJ} / \mathrm{m}^{2} \cdot \mathrm{yr}\right]\right)$. The PV system offsets about $8 \%$ of the total annual energy load.

\subsection{Lessons Learned}

Experience with the Visitor Center Complex project, from early conceptual design through three years of postoccupancy monitoring, led to the following prominent conclusions. Although the design can be replicated by the NPS for future visitor centers, many of the conclusions are applicable to commercial buildings in general, especially retail operations. The Comfort Station portion of the project is typical of many highway rest areas and state park facilities and concepts from this design could be easily replicated across many future buildings.

- A multiple-use commercial building that includes retail, office, and public assembly spaces, can be constructed that uses $62 \%$ less site energy than an equivalent, minimally code-compliant building.

- It is possible to actively control buildings to reduce electrical demand charges.

- For the climate and scale of the Visitor Center Complex, it is possible to eliminate mechanical air systems and use simple localized heating systems to augment passive heating and cooling to provide occupant thermal comfort.

- Cooltowers can effectively combine direct evaporative cooling and passive natural ventilation and deliver comfort comparable to mechanical direct evaporative cooling.

- Daylighting can be used to augment electric lighting in retail spaces.

- Dark ceilings must be avoided to fully take advantage of the daylighting and uplighting.

- Solar-electric uninterruptible power systems can add value to commercial buildings in areas with poor power reliability.

- A PV system can provide emergency power, offset peak loads, and reduce energy costs by reducing demand.

- Changes in rate structures can change the design decisions and operating strategies.

- Commercial buildings may shift from being cooling dominated to heating dominated because of low-energy design. 
The probability that a low-energy building will be achieved is improved by adopting the low-energy design process described in this paper. That process includes: (1) setting energy performance goals early on and remaining committed to achieving them, (2) assembling a diverse design team and involving them in all phases of the project, (3) applying computer simulation to predict energy performance at multiple stages of the design process, (4) using the architecture of the building itself to reduce energy needs and enhance comfort, and (5) evaluating delivered performance and continuously commissioning systems to improve performance. For Zion, we learned that the low-energy design process enabled the building to achieve remarkable energy savings.

\subsection{Future Research}

As with any research project, future research topics are possible, as indicated below.

- Continuous monitoring of building energy performance is essential to the long-term vision of the energy performance of the building. Identify areas of degrading performance with time.

- Develop peak demand algorithms for minimizing electrical cost to fully benefit from energy efficiency devices (especially the daylighting) and the on-site generation capacity, including modeling the building and the PV system with a 15-minute time step in an integrated building simulation program. Study the ability for PV systems to minimize demand with controls.

- Perform water consumption and cost analysis for the cooltowers compared to a typical airconditioning system. The analysis will include a simulation study on the energy and water use tradeoffs for cooling commercial buildings.

- Identify better methods for natural ventilation systems or improve the robustness of the actuators.

- Identify methods to reduce glare in the spaces.

- Identify better methods of eliminating task lighting in the retail space.

- Simulations are critical throughout the design process. Many of the issues resulted from lack of simulation during a portion of the design process. Development of automated building energy simulation optimization tools can make the simulation task faster and easier, and therefore more likely to be applied when needed.

- Develop an as-built whole-building energy model of the Visitor Center that would include Trombe walls, cooltowers, subhourly demand limiting controls, and PV generation. An EnergyPlus model could be developed for further study of demand limiting controls with onsite generation, water use in evaporative cooling systems, and enable an as-built to base-case simulation comparison for determining energy and cost savings (EnergyPlus 2005). 


\section{References}

ASHRAE 1989. ANSI/ASHRAE/IES Standard 90.1-1989. Atlanta, GA: American Society of Heating, Refrigerating, and Air-Conditioning Engineers.

ASHRAE 2001. ASHRAE Handbook Fundamentals. Atlanta, GA: American Society of Heating, Refrigerating, and Air-Conditioning Engineers.

ASHRAE 2004. ASHRAE Standard 90.1-2001 Addendum E. Atlanta, GA: American Society of Heating, Refrigerating, and Air-Conditioning Engineers.

Atif, M.R.; Love, J.; Littlefair, P. 1997. Daylighting Monitoring Protocols and Procedures for Buildings. A report of IEA Task 21/Annex 29 Daylight in Buildings. Paris, France: International Energy Agency.

Balcomb, J.D.; Barker, G.; Hancock, C.E. 1998. "An Exemplary Building Case Study of the Grand Canyon South Rim Residence.” NREL/TP-550-24767. Golden, CO: National Renewable Energy Laboratory.

Brager, G.; de Dear, R. 2000. “A Standard for Natural Ventilation.” ASHRAE Journal. Vol. 42, No. 10; pp. 21-28.

Carlson, S.W. 2000. "Performance Monitoring of a Sustainable Residence Hall at Northland College." Research Report 198-1. Madison, WI: Energy Center of Wisconsin.

DOE 1995. Code of Federal Regulations 10 - Energy. Washington, D.C.: Office of the Federal Register National Archives and Records Administration.

DOE 2003. 2003 Buildings Energy Databook. Washington, D.C.: U.S. Department of Energy. Pg. 1-1, Table 1.1.3. http://buildingsdatabook.eren.doe.gov/. Accessed July 2004.

DOE 2004. High-Performance Buildings initiative Web site. Washington, D.C.: U.S. Department of Energy. www.highperformancebuildings.gov. Accessed August 2004.

EIA 2000. Annual Energy Outlook. U.S. Department of Energy. Washington, DC: Energy Information Agency. Pg. 217, Diagram 5.

EIA 2002. 1999 Commercial Buildings Energy Consumption Survey: Consumption and Expenditures Tables. Washington, DC: Energy Information Agency.

EnergyPlus 2005. EnergyPlus User's Manual, V1.2.1; December 2004. Engineering Document. Washington, DC: U.S. Department of Energy. http://www.energyplus.gov/. Last accessed February 24, 2005.

EPA 2003. Emissions and Generation Resource Integrated Database. Washington, DC: Environmental Protection Agency. http://www.epa.gov/cleanenergy/egrid/index.html. Accessed September 2003.

Hicks, T.W.; von Neida, B. 2000. “An Evaluation of America's First ENERGY STAR Buildings: The Class of 1999," ACEEE Summer Study on Energy Efficiency in Buildings Proceedings; 2000, Pacific Grove, CA. Pg 4.181, Table 1.

IESNA 2000. Lighting Handbook-Reference and Application Volume. New York: Illuminating Engineering Society of North America.

King, D.L. Kratochvil, J.A. Boyson, W.E Bower, W.I. 1998. "Field Experience with a New Performance Characterization Procedure for Photovoltaic Arrays." Proceedings of the $2^{\text {nd }}$ World Conference and Exhibition on Photovoltaic Solar Energy Conversion; July 1998, Vienna, Austria. 
Lindsey, G.; Todd, J.; Hayter, S. 2003. A Handbook for Planning and Conducting Charrettes for HighPerformance Projects. Golden, CO: National Renewable Energy Laboratory. NREL/BK-710-33425.

Mermoud, A. 1996. PVSYST Version 3.2. User's Manual. Geneva, Switzerland: University of Geneva, University Center for the Study of Energy Problems. Available online at http://www.pvsyst.com/. Accessed December 2002.

NPS 1995. "Zion Canyon Comprehensive Design.” Washington, D.C.: National Park Service. U.S. Department of Interior.

NPS 2003. Zion National Park Map and Guide. Washington, D.C.: National Park Service. U.S. Department of Interior. www.nps.gov/zion/MapGuidesummer_2003.pdf.

Pless, S; Torcellini, PA. 2004. "Energy Performance Evaluation of a Low Energy Academic Building" NREL/TP 550-33180. Golden, CO: National Renewable Energy Laboratory.

Torcellini, P. A.; Hayter, S. J.; Judkoff, R. (1999). "Low-Energy Building Design-The Process and a Case Study." ASHRAE Transactions, Vol. 105, Part 2. Atlanta, GA: American Society of Heating, Refrigerating and Air-Conditioning Engineers, Inc.; pp. 802-810; NREL Report No. 26144

Winkelmann F.C.; Birdsall B.E.; Buhl W. F.; Ellington K. L.; Erdem, A. E.; Hirsch, J. J.; Gates, S. 1993. DOE2 Supplement, Version 2.1E, LBL-34947. Lawrence Berkeley National Laboratory. Springfield, Virginia: National Technical Information Service. 


\section{Appendix A The Low-Energy Design Process}

\section{The Low-Energy Design Process}

In the traditional building design process, the architectural team first creates a building program. The program specifies the needs for the building and parameters that should be considered in the design. Based on this program of requirements, the architectural team then establishes the massing and form of the building facade, including orientation, color, window area, and window placement. The criteria by which the architectural team might evaluate energy efficiency improvements include first cost, simple payback, savings-to-investment ratio, life-cycle cost, or net present value of savings.

After the building form and envelope are initially designed, the floor plans are passed to the engineering team, who designs the HVAC systems. Most engineers then work within the context of the building form and envelope as designed, focusing on improving the HVAC systems. However, because many important architectural decisions are set at this point, few changes can be made. The engineer also evaluates compliance with applicable energy codes and acceptable levels of environmental comfort for building occupants during this stage of the process.

In contrast to the traditional process, in the low-energy design process the building owner, architect, engineer, and energy consultant form a collaborative design team focused on energy and energy cost savings for the building from the onset of the project. Once the design team commits to energy goals for the project, the low-energy design process will guide the team toward good decision-making and trade-off analysis without sacrificing the building's programmatic requirements.

Low-energy design must first meet or exceed all functional and comfort requirements of the building program. Low-energy design does not imply that building occupants must endure conditions considered unacceptable in traditional buildings. However, Brager and deDear (2000) have shown that some lowenergy design strategies result in occupants being more tolerant of varying indoor conditions, increasing opportunities for application of these approaches.

The low-energy design process begins in predesign, where the building size, type, location, and use are known. The process then continues through design, construction, and commissioning according to the following steps. These steps assume a team committed to low-energy building design already has been formed (Torcellini et al 1999).

Step 1: Predesign. During predesign, the design team develops a thorough understanding of the building site, local weather patterns, and building functional requirements. Examining these issues early often leads to potential solutions for minimizing building energy consumption. At this point, the design team should brainstorm energy solutions, especially those that affect the architecture. Refinements of the concepts will happen later in the design process. It must be noted that all buildings are unique and will have a different minimization strategy. Also at this stage, the team establishes preliminary metrics, which may include percent energy savings, percent energy cost savings, or emission reductions. It is critical that the entire team understand these goals and how design features impact those goals.

Step 2: Create a Base-Case Building Model. The low-energy design process is a simulation-based, quantitative, and qualitative method to help architects and engineers create low-energy buildings. Lowenergy design is not intuitive. Building energy use and energy cost depend on the complex interaction of many parameters and variables. The problem is far too complex for rule-of-thumb or hand calculations. The interactions are best studied using computerized energy simulation software to thoroughly evaluate all interactions among the building envelope, HVAC system, and design features.

To determine energy saving opportunities, the design team starts by simulating a base-case model of the building with a building-energy simulation program. In general terms, a base-case building is "solar neutral." For ZNP, the base-case design was a square floor plan with windows distributed equally on 
each facade. It has the same floor area as the proposed building and complies with the prescriptive standards of the applicable energy code for the building type and location. Based on the base-case model, the building energy program simulates annual loads and peak demands for heating, cooling, lighting, plug loads and HVAC system fans and pumps, providing an energy-use profile for the base-case building. Although not available at the time of design, ASHRAE Standard 90.1-2001 Appendix G (90.1 Addendum E) has standardized the base-case building definition (ASHRAE 2004).

Step 3: Parametric Analysis. An elimination parametric analysis provides building designers with an understanding of the sensitivity of total building energy performance at specific loads. In a parametric analysis, loads such as conduction losses, people, solar gains, and plug loads are removed from the simulation one at a time. As each load is removed, the impact on the metric, such as energy costs, is recorded. For example, if eliminating all conductive heat transfer through the building envelope has a small affect on energy consumption and energy costs, there is little sense in increasing building insulation levels beyond those prescribed by code. Similarly, parametric modeling may demonstrate an upper limit to the amount of insulation before internal loads begin to increase air-conditioning loads. The design team may find that reducing insulation levels and using the money to reduce energy elsewhere has a larger impact on the total energy picture. If, however, eliminating all solar gains greatly affects energy performance, then it is worth exploring solar related issues such as window area, orientation, window solar heat gain coefficient (SHGC), and shading. Finally, the team establishes the energy goal for the climate and building type based on this analysis. All team members should agree on the feasibility of achieving this goal.

Step 4: Brainstorm Design Solutions. In this stage, the design team brainstorms possible solutions to energy issues, focusing on solutions relating to building geometry. For example, daylighting might be a solution if lighting loads and associated cooling loads are a large percentage of building energy use. If winter heating loads are an important issue, passive solar heating may be desirable. These solutions significantly impact decisions on building geometry, siting, zoning, and orientation, which are all aspects of a building that are difficult or impossible to alter later in the design process.

Step 5: Simulate Performance of Design Solutions. Simulations are performed on variants of the basecase building based on the list of possible solutions developed in Step 4. Issues that influence building architectural elements are explored first. The simulated building energy use of each variant is compared to the original base-case building and other variants. Daylighting systems, thermal issues, and building control strategies may be addressed by different building disciplines, but successful low-energy performance can only be achieved by examining the interrelation between these components through building energy simulation.

Step 6: Conceptual Design. Conceptual design is the most difficult part of the energy design process. It is when important energy features must be integrated into the architectural design. The objective of lowenergy design is to use architectural and envelope features to minimize energy used for heating, cooling, and lighting. Often, energy features can also serve as major architectural features, thereby reducing first costs directly attributable to energy efficiency. If an energy feature increases construction costs, then the feature is reevaluated to ensure its effectiveness.

In Step 6, the architectural team prepares a preliminary set of drawings based on the siting, orientation, and basic geometry of the building incorporating information from simulations performed in Step 5. The energy performance of this preliminary design is also modeled at this point. Variants of the preliminary design are then simulated to provide information to the architectural team about how the design should be refined. At this stage, energy use modifications will not affect the overall form, but may have a minor influence on building appearance. Important variables to evaluate include wall-to-window surface area for each building orientation, geometry of fixed shading devices, and light shelves on each facade. Other variables to consider include window optical and heat transfer characteristics on each facade, use of natural ventilation, resistance and capacitance of walls, and quantity of internal thermal mass. 
Note that only the building envelope has been considered at this point in the design. After optimizing the energy efficiency of the building envelope, the design team then works on the HVAC design. Because slight changes in the envelope design can significantly affect total building energy loads, it is best to wait until the envelope design is well developed before considering the HVAC design so that it accurately reflects the needs of the building envelope.

Step 7: Design Development. After the architectural features affecting energy use have been established, the model for the proposed building is updated to reflect those features. A set of simulations is then performed to guide decisions regarding the HVAC system and associated controls. These simulations are primarily used to optimize annual energy use, annual energy cost, and occupant comfort. Simulations can also be used to help properly size the equipment. Low-energy buildings can defy industry norms used for equipment sizing. Downsizing equipment can substantially reduce construction cost and the savings can often be used to pay for improved envelope energy features. At this point, there will be some trade-off between mechanical system decisions and architectural features.

Step 8: Bid Documents and Specifications. Building design plans and specifications must be carefully reviewed to find areas where the design intent is not met and to catch unacceptable component substitutions. Examples include ensuring that there are no thermal bridges connecting conditioned space with the outdoors, window thermal and optical properties are sufficiently specified, HVAC equipment efficiency and performance are ample, control algorithms are adequately expressed, and R-values of insulation materials are specified. A final simulation is based on these plans and specifications to ensure a low-energy building and to show energy code compliance (e.g., the building should perform more than $50 \%$ better than the code-compliant base-case building in most cases). In the case of high construction bids, the design may need modification to reduce costs. All modifications should be closely evaluated to ensure that the original energy savings goals are maintained and the impacts of changes are well understood.

Step 9: Construction. At this phase, most of the simulation work has been completed, so simulations are performed only in response to unanticipated substitutions, changes, or additions made by the construction contractor, suppliers, architects, inspectors and others involved in building construction. Simulations at this time might include those needed to determine if a substitute component meets energy related specifications, or to review a construction detail that must be modified because of a problem at the construction site. Scheduled plan reviews and site inspections are crucial to ensure that specified details omitted from the plans do not compromise the energy design. A clear communication path between the contractor, building operator, and the design team will help ensure that components are installed properly. In many cases, once construction on a particular area is incorrectly completed, the building owner is often forced to live with the resulting energy performance consequences because correction may be impractical.

Step 10: Commissioning and Postoccupancy Evaluation. The commissioning process includes testing all subsystems in the building to ensure that they operate as intended. For example, poorly calibrated economizer controls or daylight sensors may allow excess air to enter or cause lights to stay on for excessive periods. Occasionally, simulations are required to help solve problems that emerge during this final phase and to respond to changes in building use that may occur once the building is occupied. The key is to maintain controls that function in harmony with building design intent. A good building quickly becomes a "bad" building with improper control strategies. In addition, it is important to educate the building owner, occupants, and the maintenance staff about how to properly use the building systems as conceived by the design team. The building's operating energy performance can only be optimized if individual occupants and/or building operators are able to understand how these systems interact. 


\section{Appendix B Design Process Questionnaire}

\section{Questionnaire}

The following questionnaire was sent to those involved in the design of the Visitor Center Complex:

\section{Questionnaire and Round Table Meeting}

A questionnaire and a round table meeting will be used to capture and record what worked and what did not work in the design process. The questionnaire will be distributed and collected first, followed shortly thereafter by a round table meeting.

This feedback will help inform future design teams of the critical elements involved in the design process. Please be frank and honest. All responses will be anonymous. Data will be compiled solely for aiding future design projects.

You can write on the back of the page if insufficient space is provided for your answer. Do indicate the question number that you are addressing.

Please print this document, answer the questions, and return to Patrick Shea by October 29, 1998. Thank you for your time and cooperation.

Sincerely,

Stefan Craine

NREL Analyst

Please call me at (303) 384-7566 if you have any questions regarding this questionnaire. 
Date:

1. What was your position on the design team? (Please select all that apply)

Architect

Landscape Architect

Electrical Engineer

Mechanical Engineer

Project Manager

Owner

Building Operator

Building Occupant

Other

2. Please define your understanding of your role in the sustainable design plan.

3. Do you think that the sustainable design plan was developed successfully?

OYes ONo

4. What specifically helped the development of the sustainable design plan?

5. What specifically inhibited the development of the sustainable design plan?

6. In your opinion, what are the critical elements that need to be addresses when developing a sustainable design plan? 
7. Please rate how well informed you were of the project goals during the design plan.

V Very informed OMildly informed OMildly misinformed OVery misinformed $\mathrm{O} / \mathrm{A}$

8. I understood the goal of the design plan specific to the roles of the following stakeholder: (please check accordingly for each stakeholder. Included others at the " $\mathrm{X}$ " if necessary)

\begin{tabular}{|l|l|l|l|l|}
\multicolumn{2}{|c}{ Strongly Agree } & \multicolumn{2}{c|}{ Mildly Agree } & \\
\hline NPS & & & & \\
\hline ZION & & & & \\
\hline Federal Gov't & & & & \\
\hline NREL & & & & \\
\hline Cinnemax & & & & \\
\hline$X$ & & & & \\
\hline$X$ & & & & \\
\hline
\end{tabular}

9. Please rate how well informed you were of project changes during the design plan.

OVery informed OMildly informed OMildly misinformed OVery misinformed $\bigcirc$ N/A

10. I understood why changes occurred to the design plan specific to the roles of the following stakeholder: (please check accordingly for each stakeholder. Included others at the " $\mathrm{X}$ " if necessary)

\begin{tabular}{|l|l|l|l|l|}
\multicolumn{2}{c}{ Strongly Agree } & \multicolumn{2}{c|}{ Mildly Agree } & \multicolumn{2}{c|}{ Mildly Disagree } & Strongly Disagree \\
\hline NPS & & & & \\
\hline ZION & & & & \\
\hline Federal Gov't & & & & \\
\hline NREL & & & & \\
\hline Cinnemax & & & & \\
\hline X & & & & \\
\hline X & & & & \\
\hline
\end{tabular}

11. I feel that I understood the role of the NPS team in the design process.

OStrongly Agree OMildly Agree OMildly Disagree OStrongly Disagree O N/A

12. I feel that the NPS team members communicated clearly to each other.

OStrongly Agree OMildly Agree OMildly Disagree OStrongly Disagree $\mathrm{O}$ N/A 
13. I feel that the NPS team responded to each others needs promptly.

OStrongly Agree OMildly Agree OMildly Disagree OStrongly Disagree $\mathrm{O}$ N/A

14. I feel that the NPS team was open to new ideas.

OYes ONo (Please Explain)

15. I feel that I understood the role of NREL in the design process.

OStrongly Agree OMildly Agree OMildly Disagree OStrongly Disagree $\mathrm{O}$ N/A

16. I feel that NREL communicated their ideas clearly.

OStrongly Agree OMildly Agree OMildly Disagree OStrongly Disagree O N/A

17. I feel that NREL responded to the design teams needs promptly.

OStrongly Agree OMildly Agree OMildly Disagree OStrongly Disagree O N/A

18. I feel that NREL was open to ideas.

OYes ONo (Please Explain)

19. Was NREL's participation beneficial to the design process?

OYes ONo (Please Explain)

20. Did the design team interact and work well with each other?

OYes ONo (Please Explain) 
21. How would you strengthen the team?

22. What would you have done differently if given the opportunity?

23. Additional comments: (Please write anything that you would like to discuss e.g. successes, frustrations, concerns, problems, solutions) 


\section{Questionnaire Results}

Based on the questionnaire from Appendix A, survey results are summarized based on six responses.

Do you think the sustainable design plan was developed successfully?

$$
\begin{array}{lll}
17 \% & 66 \% & 17 \%
\end{array}
$$$$
\uparrow-----\uparrow \text {----- } \uparrow
$$

Not successfully [ $\left[\begin{array}{lllllllllll}-5 & -4 & -3 & -2 & -1 & 0 & 1 & 2 & 3 & 4 & 5\end{array}\right]$ Very Successfully

Please rate how well informed you were kept of the project goals during the design process. $100 \%$

$\uparrow$

( )Very informed ( )Mildly informed ( )Mildly misinformed ( )Very misinformed ( ) N/A

Please rate how well informed you were kept of project changes during the design process. $100 \%$

$\uparrow$

( )Very informed ( )Mildly informed ( )Mildly misinformed ( )Very misinformed ( )N/A

I feel that I understood the role of the design team during the design process. $100 \%$ $\uparrow$

( )Strongly Agree ( )Mildly Agree ( ) Mildly Disagree ( ) Strongly Disagree ( ) N/A

I feel that the design team members communicated clearly to each other. $66 \% \quad 17 \% \quad 17 \%$

$\uparrow$------- $\uparrow$--------------- $\uparrow$

( ) Strongly Agree ( ) Mildly Agree ( )Mildly Disagree ( )Strongly Disagree ( )N/A

I feel that the design team responded to each others' needs promptly.

$\begin{array}{lll}66 \% & 17 \% & 17 \%\end{array}$

$\uparrow$------ $\uparrow$-------------- $\uparrow$

( )Strongly Agree ( )Mildly Agree ( )Mildly Disagree ( )Strongly Disagree ( )N/A 
The design team interacted and worked well with each other?

$100 \%$

$\uparrow$

( ) Agree ( )Disagree

I feel that NREL communicated their ideas clearly.

$100 \%$

$\uparrow$

( ) Strongly Agree ( )Mildly Agree ( )Mildly Disagree ( )Strongly Disagree ( )N/A

I feel that NREL responded to the design teams' needs promptly.

$67 \%--33 \%$

$\uparrow \uparrow$

( ) Strongly Agree ( )Mildly Agree ( )Mildly Disagree ( )Strongly Disagree ( )N/A

I feel that NREL was open to my ideas and thoughtfully listened to them.

$100 \%$

$\uparrow$

( Yes ) ( No)

NREL's participation benefited to the design process?

$100 \%$

$\uparrow$

( Yes) ( No) 
Results of specific questions are included below. The question, paraphrased answers, and a general summary of answers are provided.

\section{What promoted development of the sustainable design?}

- Individual enthusiasm, genuine interest in project by NREL \& design staff and by the NPS as well

- Good policy \& agency goals (design team pushing envelope of sustainable design)

- Relocation of traditionally indoor visitor space to outdoor area

- Team cohesiveness.

The individual enthusiasm of NREL and architectural design staff as well as the motivation of NPS staff all contributed toward the development of a viable sustainable design for the Visitor Center. The project was viewed by many as an opportunity to push the envelope of sustainability, which led to a sense of team cohesiveness among the participants. During design and construction, many novel approaches were applied in an effort to conserve resources. One such approach involved relocating traditionally interior visitor functions to the outdoor environment, resulting in reduced facility dimensions with a comparable reduction in energy use.

What inhibited development of a sustainable design?

- Traditional/limited materials, construction practices

- High visitor expectations

- Economic limitations (high cooltower cost)

- Park service bureaucracy

- Similar design failures of the past

- Design personnel with no knowledge of arid climate or incorporated technologies

- Pedestrian site flow produced less than optimum solar building orientation.

However, the success of the design was also partially hindered by several other factors. Traditional expectation and cultural norms in materials selection and construction techniques were at the foremost of the problems addressed. Adapting to the deviation from standard procedure was found to be difficult for some individuals. In general, the unconventional nature of the building coupled with the high cost of the cooltowers was initially cause for apprehension because similar facilities built previously had failed to perform adequately. "Quote" Optimum solar design was also somewhat compromised in order to accommodate pedestrian traffic through the site. Despite these issues, the structure's energy savings have adequately surpassed that of its predecessors.

What are the critical design processes that need to be addressed?

- Promote free flow of ideas and frequent communication with designers to promote fully integrated design

- Attract laymen/stakeholders/decision makers by avoiding technical excess

- Emphasize sustainability

- Understanding of regional/social/cultural context (especially climate) 
- Make sustainable materials selection, and other technology need to be made known at the early stages of project development (Contributes to integrated design).

Several individuals felt the design process could be greatly optimized by making the available materials and technology selection known before project initiation. Because many features were implemented late in the design process, their appearance was of awkward additions to the original project. Increased communication with designers should be emphasized in the future in order to promote a more integrated design. Detailed information about the local environment should also be made available to reduce the chances of overcompensating the design mechanically. Communication should not use an excess of technical details, in order to avoid the possibility of alienating stakeholders and decision makers.

\section{The design team interacted and worked well with each other?}

- Strong, cohesive project vision

- Team captain played important role in organizing the work

- All responders to the questionnaire unanimously felt that the design team interacted and worked well with each other.

How would you strengthen the team? Why?

- Retain original team members if project continues

- Be more open about researching and incorporating unapplied sustainable practices and technologies

- Coordinate and streamline time usage amongst participating parties to taking longer than necessary.

Team strength could potentially be improved upon by utilizing better time management. A strategy that coordinates the progress of all disciplines involved would be most beneficial. In addition, a deeper exploration of sustainable practices and technologies beyond those currently applied, and retention of current team members in future endeavors could also enhance team efficacy.

\section{What do you think NREL's role is in the design process?}

- Assist in creation of project vision, detailing material sources, advocating \& presenting technologies

- Concept testing, research, technical input

- Review and comment on drawings and specifications

- Evaluate facility after construction to determine success and recommend necessary modifications needed to increase efficiency

- Provide energy use calculations before construction to assist design team in making decisions.

NREL's role in the project design process was felt to be best suited to providing the team with conceptual and technical input. Specifically, the most useful assistance arrived in the form of review and comment on drawings and proposed specifications, project vision creation, material source details, and the presentation of various renewable technologies. Energy use calculations provided before construction assisted in the design team decision-making process. No less important was the need to evaluate facility performance after construction to determine design success and recommend modifications needed to increase efficiency. 


\section{I feel that NREL communicated their ideas clearly.}

- Explanations specially tailored for various audiences

- Paul Torcellini effectively communicated ideas \& recommendations as part of design team

- Recommendations added value to the designer's work (avoided detracting from it)

- Paul Torcellini deserves credit for pitching the sustainable goals and concepts of the project and design team, which resulted in eventual funding of the project.

Overall, communication took place successfully and problems encountered were virtually nonexistent. Paul Torcellini played an effective role in communicating ideas and recommendations to the design team, as well as selling the sustainable goals and concepts. This was largely responsible for eventual funding for the project, and was credited for adding value to the original design.

\section{I feel that NREL responded to the design team's needs promptly.}

- Single point of contact [Paul Torcellini \& Mark Golnar (NPS Mechanical Engineer)] worked well for reducing time spent communicating amongst team members

- Reviews, sub-consultants, technical info were all timely

- Large NREL workload slowed response times occasionally, but did not present a problem.

NREL responded to a majority of team requests with accuracy and speed. Paul Torcellini and Mark Golnar played a significant role in facilitating this by serving as a single point of contact for team communication. This structure allowed reviews, sub-consultants and technical information to be distributed very quickly. Occasionally, substantial demand for NREL's services were cause for minor delay, but did not end up posing a significant threat toward the progression of ongoing activities.

\section{I feel that NREL was open to my ideas and thoughtfully listened to them.}

- Common sense methods were always applied to accomplish project goals

- Philosophical or technical differences were addressed in a professional manner

- Ideas about backup heating in the visitor area were received well by NREL staff.

It was generally felt that ideas were well accepted, and common sense methods were used to implement these goals. Cooperation amongst the design team was complemented with a marked professionalism in resolving group differences. A mechanical engineer involved with the project remarked about how well his proposal for heating the visitor area was received.

\section{Was NREL's participation beneficial to the design process?}

- Success achieved would not be as significant had NREL not been involved with the project

- Critical input and information provided, even at early stages of development

- Background, knowledge, and strength of vision all contributed toward a functional and visually appealing design

- Helpful knowledge supplied, included information about calculating passive solar heating outputs and mass storage contributions with regard to design of the backup heating systems.

NREL's participation in the project was essential for achieving success in the design. The background and vision provided were useful in attaining both a functional as well as visually appealing design. This took the form of critical input regarding progress of the design process from early stages to project conclusion. Specifically, information about passive solar heating output and mass storage calculations were given to otherwise inexperienced members. 


\section{What would you have done differently if given the opportunity?}

- Modifications to original procedure are unnecessary. Continue to use a project formulation that promotes the establishment of vision.

- Exploring and utilizing a broader expanse of materials would positively complement design of the most sustainable facility.

- Exploration could also have included looking further into solar electrical generation.

- Design of the BAS could have been carried out during preliminary stages of the design process instead of the final phases.

- Pressure to complete the project in a very short time period may have hindered sustainability and the design process as a whole. Organization suffered.

- Some minor skepticism was relayed about the longevity of the digital building control mechanisms.

In retrospect, original design procedures were considered very close to ideal, with changes being largely unnecessary. However, requests for a closer look at broadening materials selection practices have been a recurring theme. Concerns about the building control systems have taken a close second in line. Some feel longevity may become an issue in the next 5-10 years, while others are simply concerned about how late the system was conceived in the design process. This, combined with a short time period allotted for construction, may have pushed the limits of group organizational capabilities. 


\section{Appendix C Energy Summary Tables}

\begin{tabular}{|c|c|c|c|c|c|c|c|c|c|c|c|c|c|}
\hline MEASURED DATA (kWh) & Nov-01 & Dec-01 & Jan-02 & Feb-02 & Mar-02 & Apr-02 & May-02 & Jun-02 & Jul-02 & Aug-02 & Sep-02 & Oct-02 & Annual \\
\hline Total Consumption & 6,284 & 12,191 & 12,947 & 8,160 & 7,592 & 5,880 & 5,766 & 6,192 & 7,257 & 6,950 & 6,217 & 7,440 & 92,876 \\
\hline PV Production & 355 & 319 & 428 & 561 & 785 & 779 & 965 & 919 & 850 & 826 & 571 & 503 & 7,860 \\
\hline Net Purchased & 5,930 & 11,872 & 12,519 & 7,600 & 6,807 & 5,101 & 4,801 & 5,273 & 6,407 & 6,124 & 5,646 & 6,937 & 85,016 \\
\hline HVAC & 1,361 & 7,525 & 8,256 & 4,420 & 3,611 & 1,133 & 589 & 1,227 & 2,126 & 1,830 & 1,166 & 472 & 33,716 \\
\hline Visitor Center Heating & 997 & 6,957 & 7,554 & 4,022 & 3,150 & 774 & 87 & 0 & 0 & 0 & 0 & 0 & 23,541 \\
\hline Comfort Station Heating & 47 & 278 & 341 & 182 & 182 & 0 & 0 & 0 & 0 & 0 & 0 & 0 & 1,030 \\
\hline Visitor Center Cooling & 2 & 0 & 0 & 0 & 0 & 0 & 137 & 615 & 942 & 923 & 638 & 195 & 3,453 \\
\hline Comfort Station Cooling & 0 & 0 & 0 & 0 & 0 & 0 & 7 & 196 & 304 & 330 & 111 & 0 & 948 \\
\hline Visitor Center and Comfort Station Ceiling and Exhaust Fans & 314 & 290 & 362 & 216 & 279 & 360 & 358 & 416 & 880 & 577 & 416 & 277 & 4,743 \\
\hline Lighting & 2,269 & 2,094 & 2,224 & 1,871 & 1,775 & 2,301 & 2,483 & 2,261 & 2,322 & 2,497 & 2,597 & 4,262 & 28,957 \\
\hline Visitor Center Computer Controlled & 1,191 & 1,115 & 1,093 & 939 & 984 & 1,237 & 1,154 & 1,206 & 1,280 & 1,309 & 1,439 & 2,169 & 15,115 \\
\hline Visitor Center Switch Controlled & 338 & 292 & 285 & 279 & 334 & 428 & 518 & 517 & 623 & 581 & 625 & 476 & 5,297 \\
\hline Comfort Station & 459 & 459 & 634 & 497 & 330 & 396 & 596 & 351 & 213 & 368 & 380 & 1,061 & 5,744 \\
\hline Outdoor & 281 & 228 & 212 & 156 & 126 & 240 & 214 & 188 & 206 & 239 & 154 & 557 & 2,800 \\
\hline Equipment/Other & 2,645 & 2,573 & 2,466 & 1,869 & 2,206 & 2,445 & 2,695 & 2,705 & 2,814 & 2,623 & 2,456 & 2,706 & 30,204 \\
\hline Fee Station & 590 & 768 & 747 & 306 & 201 & 304 & 264 & 218 & 266 & 242 & 205 & 522 & 4,632 \\
\hline Visitor Center Plug Loads & 1,690 & 1,406 & 1,249 & 1,163 & 1,412 & 1,501 & 1,682 & 1,766 & 1,642 & 1,702 & 1,659 & 1,579 & 18,451 \\
\hline Comfort Station Plug Loads & 158 & 247 & 286 & 255 & 420 & 450 & 372 & 265 & 464 & 266 & 246 & 255 & 3,680 \\
\hline Visitor Center Domestic Hot Water & 55 & 57 & 72 & 70 & 81 & 84 & 82 & 74 & 60 & 56 & 58 & 52 & 799 \\
\hline Comfort Station Domestic Hot Water & 153 & 95 & 113 & 75 & 92 & 107 & 294 & 383 & 382 & 357 & 287 & 299 & 2,630 \\
\hline
\end{tabular}

\begin{tabular}{|c|c|c|c|c|c|c|c|c|c|c|c|c|c|}
\hline MEASURED WEATHER BASE CASE (kWh) & Nov-01 & Dec-01 & Jan-02 & Feb-02 & Mar-02 & Apr-02 & May-02 & Jun-02 & Jul-02 & Aug-02 & Sep-02 & Oct-02 & Annua \\
\hline Total Base-case Consumption & 16,540 & 19,550 & 18,885 & 15,476 & 17,106 & 17,159 & 19,909 & 24,610 & 28,348 & 26,621 & 20,778 & 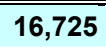 & $241,70 €$ \\
\hline Base-case Heating & 1,998 & 6,259 & 5,445 & 2,970 & 2,237 & 380 & 277 & 176 & 27 & 123 & 213 & 503 & 20,608 \\
\hline Base-case Cooling & 1,704 & 22 & 98 & 535 & 1,611 & 4,010 & 6,251 & 11,378 & 14,762 & 13,001 & 7,653 & 2,890 & 63,915 \\
\hline Base-case Fans & 1,542 & 1,597 & 1,597 & 1,439 & 1,594 & 1,543 & 1,603 & 1,616 & 1,776 & 1,732 & 1,557 & 1,594 & $19,19 d$ \\
\hline Base-case Lighting & 8,859 & 9,154 & 9,154 & 8,267 & 9,154 & 8,859 & 9,154 & 8,859 & 9,154 & 9,154 & 8,859 & 9,154 & 107,781 \\
\hline Base-case Equipment & 2,223 & 2,368 & 2,365 & 2,115 & 2,332 & 2,166 & 2,230 & 2,145 & 2,217 & 2,216 & 2,145 & 2,247 & 26,769 \\
\hline Base-case DHW & 214 & 150 & 226 & 150 & 178 & 201 & 394 & 436 & 412 & 395 & 351 & 337 & 3,443 \\
\hline
\end{tabular}

Figure B-1 Summary of measured and base-case energy use 


\section{Appendix D PV Shading Simulation Procedure}

To account for the mountain shading from the south of the PV array, the southern horizon line was modeled. Over the course of a year, the mountains of the southern canyon wall, as shown in Figure D-1, shade the building and the PV array in the morning and in the evening.



Figure D-1 Photo of Visitor Center looking south showing southern horizon (canyon walls) accounted for in simulations

The measured horizontal insolation, shown as monthly profiles in Figure D-2, demonstrates the morning and evening canyon wall shading. On average for the month of December, the building is shaded until 9:30 a.m. and unshaded until the end of the day. On average for the month of June, the building is shaded until 7:00 a.m. and again at 6:00 p.m. The sun path diagram with a horizon line in Figure D-3 shows the modeled horizon that corresponds to the morning and evening canyon wall shading.

Horizontal Insolation Load Shape



Figure D-2 Horizontal insolation monthly profile, October 2001 through October 2002 


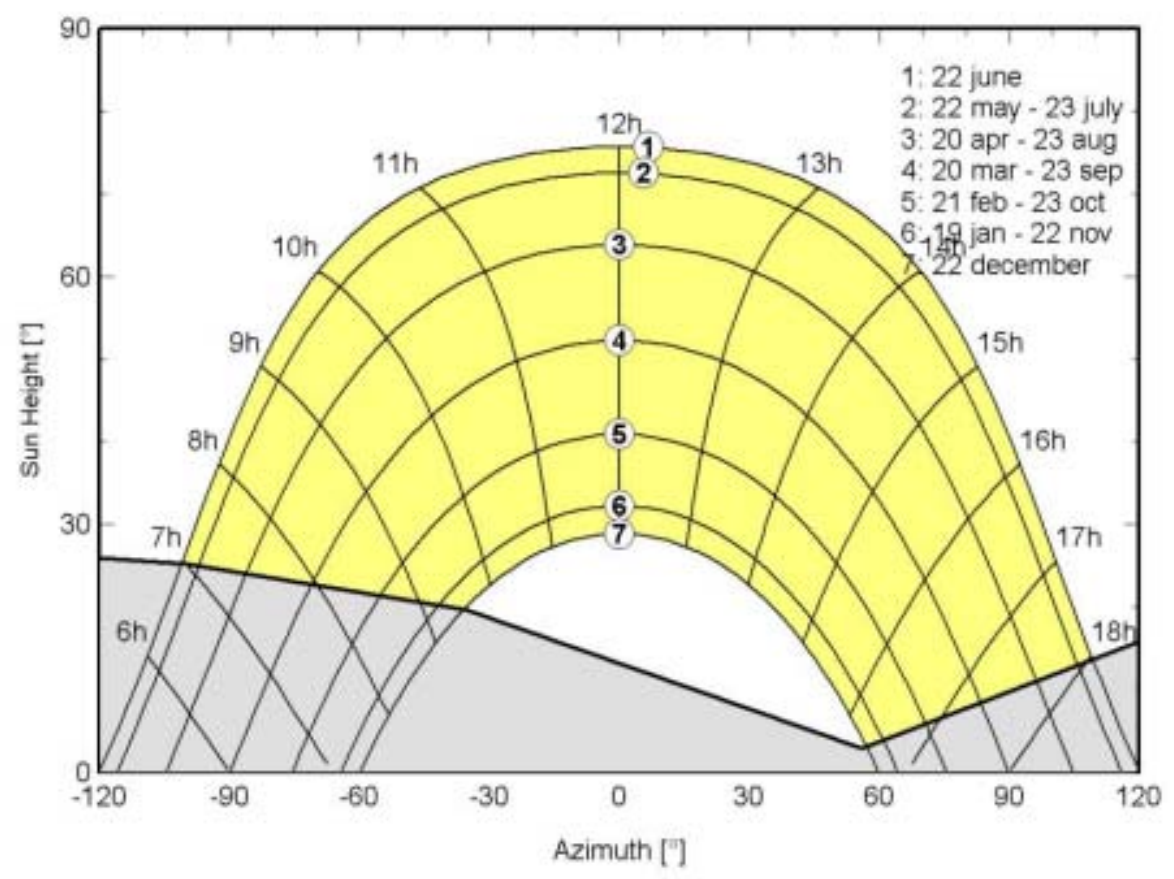

Figure D-3 Southern horizon model

Another occurrence of PV array shading is apparent in the afternoon when the trees to the west of the PV array, as shown in Figure D-4, shade a portion of the array. A picture of the shaded array taken at 3:30 p.m. on July 9, 2000, as shown in Figure D-4, demonstrates the tree shading. A 3-D representation of the tree in relation to the PV array was simulated, as shown in Figure D-5. It is possible to quantify the PV performance degradation due to this shading through simulation.

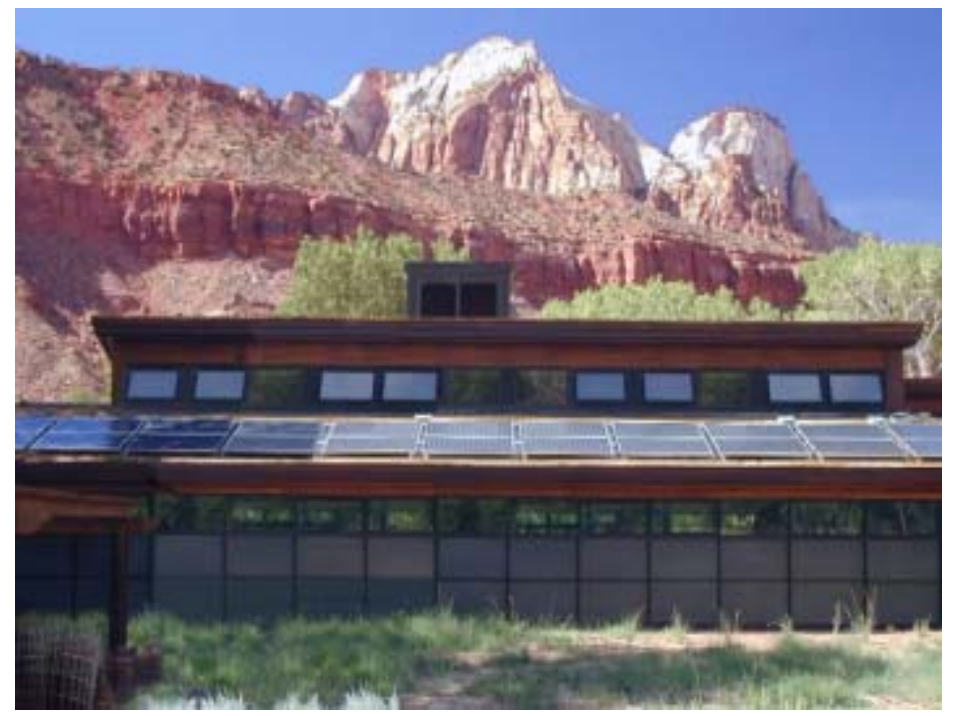

Figure D-4 Tree shading of PV array, 3:30 p.m. July 09, 2000 


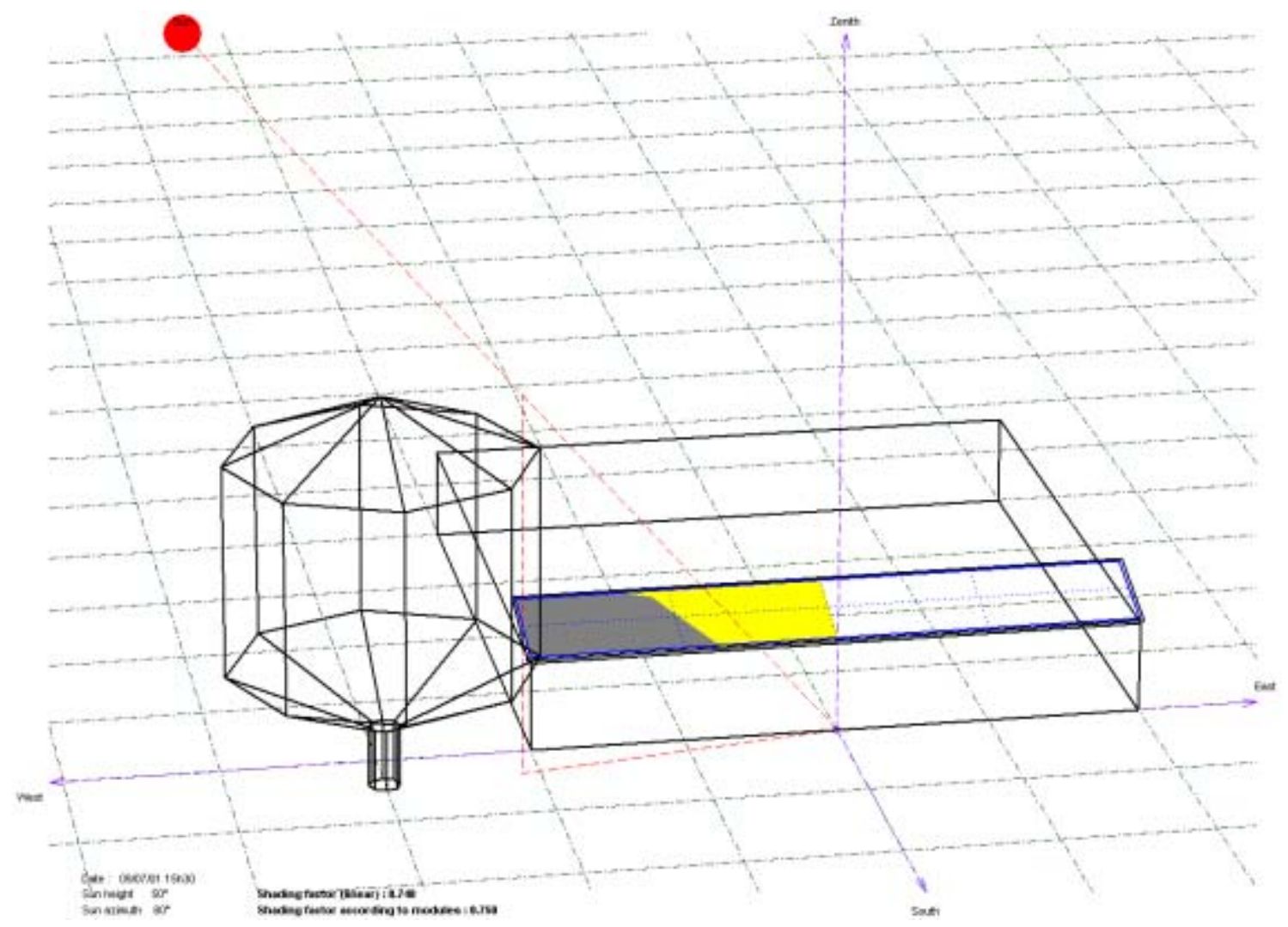

Figure D-5 Model of tree shading of PV array, 3:30 p.m. July 9, 2000 


\section{Appendix E Extended HVAC and Comfort Analysis}

\section{Portable Comfort Measurement}

During September 22, 2000 through November 29, 2000, a temperature and relative humidity sensor was placed by the cash register in the ZNHA area. According to ASHRAE Standard 55, only 5 hours were outside the comfort zone, as shown in Figure E-1. These data points occurred during the end of September and result from evaporative cooling. These temperatures are reasonable, but the humidity added because of the cooltowers resulted in a relative humidity outside of the comfort range. Again, values to the left of the comfort zone are considered comfortable because the occupants are able to control heating during the winter.

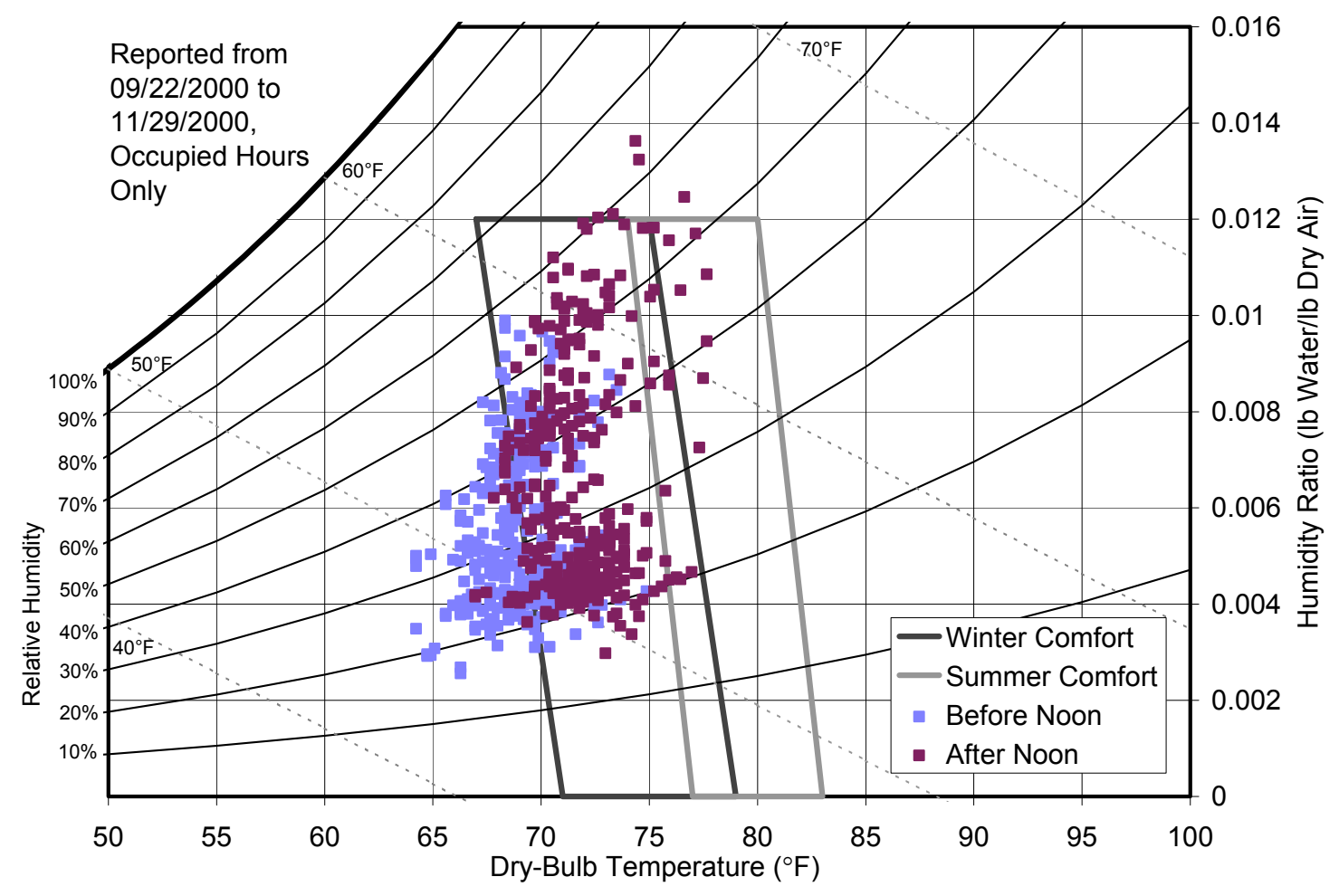

Figure E-1 Comfort chart of cash register area during occupied hours 


\section{Appendix F Extended Lighting Analysis}

Several other light readings were taking during the evaluation; see Figure F-1 and Figure F-2. Notice the higher illuminance near the windows during winter sky conditions.

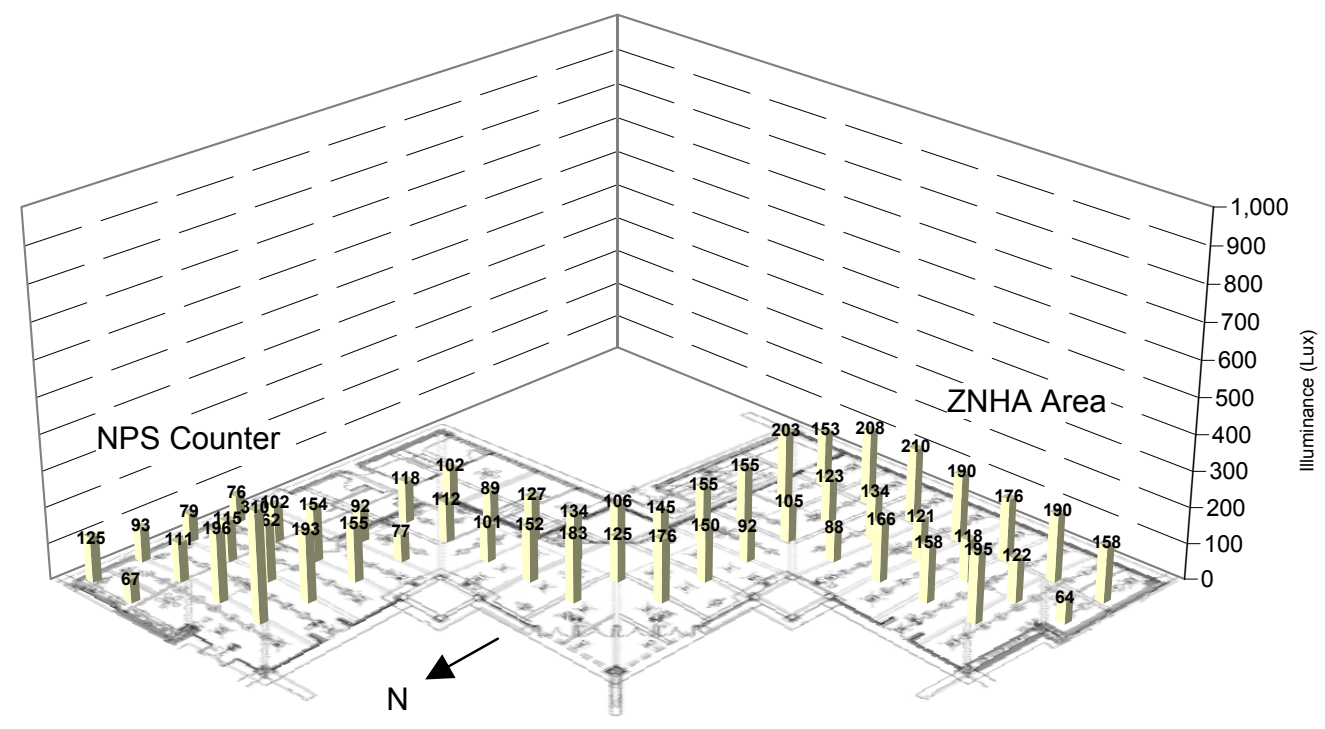

Figure F-1 Illuminance for clear sky with lights OFF; July 11, 2000 at 12:05 p.m.

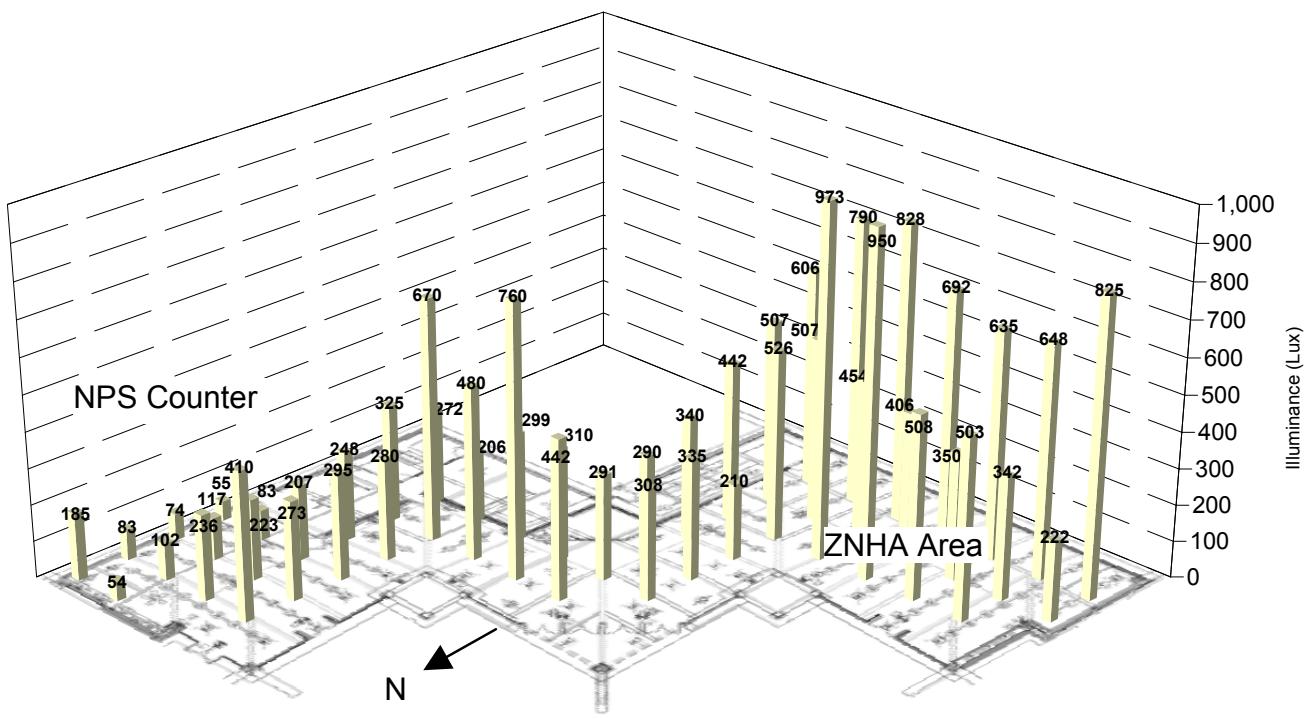

Figure F-2 Illuminance for clear sky with lights OFF on December 15, 2000 at 11:15 a.m. 


\section{Appendix G List of People Involved in Project}

Contracting Party:

Denver Service Center

National Park Service

United Stated Department of Interior

Contractor:

Bud Mahas Construction, Inc

917 Duluth Ave.

Salt Lake City, UT 84116

National Park Service Architect:

James Crockett, Larry Kilborn, Krista Copeland

National Park Service

SC-AR

P.O. Box 25287

Denver, CO 80225

Predesign Energy Concept Generation

Ron Judkoff and Paul Torcellini

National Renewable Energy Laboratory

1617 Cole Blvd

Golden, CO 80401

Energy Analysis:

National Renewable Energy Laboratory

Paul Torcellini, Ron Judkoff, Nick Long, Shanti Pless, Sheila Hayter

1617 Cole Blvd

Golden, CO 80401

MechanicalEngineer:

Mark Golnar

National Park Service

DSC-EN

P.O. Box 25287

Denver, CO 80225

Building Control Systems:

Setpoint Systems Corporation

Contact: Aaron Nahale

2680 South Platte River Drive

Denver, Colorado 80223-4208

Phone: 303-733-2300

Post Occupancy Evaluation Team:

National Renewable Energy Laboratory

Contact: Paul Torcellini, Nicholas Long, Shanti Pless

1617 Cole Blvd

Golden, CO 80401

Building Operators:

Jim Lutterman, Zion National Park

Jim Starling, Zion National Park 
Building Occupants:

Zion National Park

Zion Natural History Association

\section{Cooltower Contact:}

Martin Yoklic

University of Arizona

Environmental Research Laboratory

2601 E. Airport Drive

Tucson, AZ 85706

Phone: 520-626-3322 


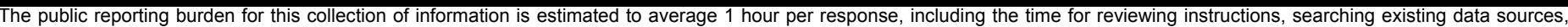

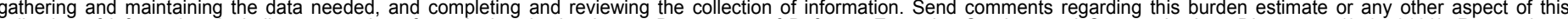

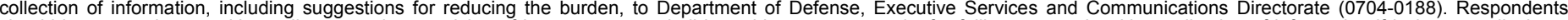

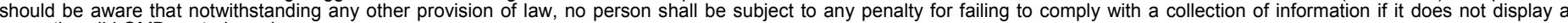
currently valid OMB control number.

PLEASE DO NOT RETURN YOUR FORM TO THE ABOVE ORGANIZATION.

\section{REPORT DATE (DD-MM-YYYY) \\ February 2005}

4. TITLE AND SUBTITLE

Evaluation of the Low-Energy Design and Energy Performance of the Zion National Park Visitor Center

\section{DATES COVERED (From - To)}

5a. CONTRACT NUMBER

DE-AC36-99-GO10337

5b. GRANT NUMBER

5c. PROGRAM ELEMENT NUMBER

5d. PROJECT NUMBER

NREL/TP-550-34607

5e. TASK NUMBER

BEC3.4005 and BEC2.4002

5f. WORK UNIT NUMBER
7. PERFORMING ORGANIZATION NAME(S) AND ADDRESS(ES)

National Renewable Energy Laboratory

1617 Cole Blvd.

Golden, CO 80401-3393
8. PERFORMING ORGANIZATION REPORT NUMBER

NREL/TP-550-34607

9. SPONSORING/MONITORING AGENCY NAME(S) AND ADDRESS(ES)

10. SPONSOR/MONITOR'S ACRONYM(S) NREL

11. SPONSORING/MONITORING AGENCY REPORT NUMBER

12. DISTRIBUTION AVAILABILITY STATEMENT

National Technical Information Service

U.S. Department of Commerce

5285 Port Royal Road

Springfield, VA 22161

\section{SUPPLEMENTARY NOTES}

\section{ABSTRACT (Maximum 200 Words)}

This report is part of a series of six case studies to develop, document, analyze, and evaluate the processes by which highly energy-efficient buildings can be reliably produced. NREL monitored the energy performance of the Visitor Center Complex at Zion National Park from September 1, 2000 to June 1, 2003. This evaluation was crucial to achieving and verifying the low-energy design goals of the building after post-occupancy. This report presents results from that multiyear performance monitoring. The Park's new transportation system was not studied as part of the building evaluation.

\section{SUBJECT TERMS}

Zion; Zion National Park; National Park; energy evaluation; energy performance evaluation; design; energy design; low-energy design; energy performance; high-performance buildings; commercial buildings

\begin{tabular}{|c|c|c|}
\hline 16. SECURITY & CLASSIFICATI & N OF: \\
\hline $\begin{array}{l}\text { a. REPORT } \\
\text { Unclassified }\end{array}$ & $\begin{array}{l}\text { b. ABSTRACT } \\
\text { Unclassified }\end{array}$ & $\begin{array}{l}\text { c. THIS PAGE } \\
\text { Unclassified }\end{array}$ \\
\hline
\end{tabular}

\begin{tabular}{l|l} 
17. LIMITATION & 18. \\
OF ABSTRACT & OF PAGES \\
UL & \\
\end{tabular}

19a. NAME OF RESPONSIBLE PERSON

19b. TELEPONE NUMBER (Include area code) 